University of San Diego

Digital USD

2019-05-19

\title{
Legal Accountability and Nonprofit Governance: An Exploratory Quantitative Study of Board Member and Executive Knowledge of Fiduciary Duties
}

Crystal Trull

University of San Diego

Follow this and additional works at: https://digital.sandiego.edu/dissertations

Part of the Business Law, Public Responsibility, and Ethics Commons, Nonprofit Administration and Management Commons, and the Nonprofit Organizations Law Commons

\section{Digital USD Citation}

Trull, Crystal, "Legal Accountability and Nonprofit Governance: An Exploratory Quantitative Study of Board Member and Executive Knowledge of Fiduciary Duties" (2019). Dissertations. 149.

https://digital.sandiego.edu/dissertations/149 
LEGAL ACCOUNTABILITY AND NONPROFIT GOVERNANCE:

AN EXPLORATORY QUANTITATIVE STUDY OF

BOARD MEMBER AND EXECUTIVE KNOWLEDGE OF FIDUCIARY DUTIES

by

Crystal Celeste Trull

A dissertation submitted in partial fulfillment

of the requirements for the degree of

Doctor of Philosophy

May 2019

Dissertation Committee

Hans Peter Schmitz Chair, PhD

Marcus Lam, Committee Member, $\mathrm{PhD}$

Afsaneh Nahavandi, Committee Member, PhD

University of San Diego 
(C) Copyright by Crystal Celeste Trull All Rights Reserved 2019 


\section{University of San Diego School of Leadership and Education Sciences}

CANDIDATE'S NAME: Crystal Trull

TITLE OF DISSERTATION:

LEGAL ACCOUNTABILITY AND NONPROFIT GOVERNANCE: AN EXPLORATORY QUANTITATIVE STUDY OF BOARD MEMBER AND

EXECUTIVE KNOWLEDGE OF FIDUCIARY DUTIES

APPROVAL:

\begin{tabular}{ll}
\hline Hans Peter Schmitz, PhD & , Chair \\
\hline Marcus Lam, PhD & Member \\
& \\
Afsaneh Nahavandi, $\mathrm{PhD}$ & Member
\end{tabular}

DATE: April 23, 2019 


\begin{abstract}
United States nonprofits are governed by boards of directors who have legal responsibilities based on the fiduciary duties of care, loyalty, and obedience. Boards, along with the chief executive, are held responsible to fulfill these standards which are designed to hold nonprofits legally accountable to carry out their tax exempt purpose by using organizational resources for the intended purpose, avoid conflict of interest, and ensure compliance. However, despite this weighty responsibility and the voluntary nature of nonprofits, no standardized process exists to educate nonprofit leaders about their legal responsibilities.
\end{abstract}

While governance is a key area of nonprofit research, there is limited empirical evidence about how nonprofit leaders satisfy legal accountability demands. Using quantitative methods, this three paper dissertation establishes baseline data about nonprofit leader fiduciary knowledge, source of knowledge, and application of knowledge in their governance activities. A survey tool developed for this study yielded 186 responses from San Diego County nonprofit leaders. Using role and board service as the primary demographics, the results show that most nonprofit leaders believe they have enough knowledge of the fiduciary duties and frequently use their knowledge in the performance of their governance duties. However, when tested for actual knowledge, only $41 \%$ of board members and $70 \%$ of executives passed. When analyzed by board service, $56 \%$ of those who served on one to four boards in the past 15 years and $31 \%$ of those who have served on five or more boards passed. Further results show that nonprofit leaders were more likely to rely on informal sources of knowledge, such as conversations 
with their colleagues and other board members and less on more formalized sources, such as board orientations or a board manual, regardless of role or board service.

Implications of this study point to the need for increased fiduciary duty knowledge amongst nonprofit leaders. Furthermore, this study can inform regulators, funders, and practitioners to develop standards and fund training to strengthen nonprofit accountability. As nonprofit leaders understand their fiduciary duties more fully, they are empowered to make decisions about organizational resources that uphold their legal responsibilities to carry out the mission.

Keywords: Nonprofit Governance, Accountability, Legal Accountability, Fiduciary Duties, Nonprofit Board Member, Nonprofit Executive Director, Nonprofit Leader Knowledge 


\section{DEDICATION}

This study is dedicated first and foremost to my Lord and Savior, Jesus Christ. Through His sacrifice that required Him to bear my sins as His own, to the point of death, I am forgiven. Because of His work, I now have an eternal hope and a joy that sustained me during the many months of doubt and feelings of inadequacy during this dissertation journey, almost to the point of giving up. This dissertation is a testament to God's grace and mercy. 


\section{ACKNOWLEDGMENTS}

I have known for many years that I would eventually get a doctorate degree. What was then just a dream is now a reality because of the support and encouragement from the many people in my life. There are many individuals who helped me along the way and I am thankful for each and every one.

I am thankful for my fellow University of San Diego PhD colleagues who made going to class something I looked forward to and for the friendships I developed at ARNOVA. I hope to stay in contact with you all for years to come.

To Bharat Mohan for his invaluable support with "the numbers", I thank you! I would not have made it without you.

To my colleagues at the Caster Center for Nonprofit and Philanthropic Research and Education at the Nonprofit Institute at the University of San Diego, Mary Jo (MJ) Schumann, Michelle Schneider (Ahearne), Kim Hunt, Azadeh Davari, Connelly Meschen, Tessa Tinkler, Carolyn Noack, Lyn Corbett, and Laura Deitrick thank you for sharing your knowledge and expertise. I learned so much about nonprofit research that was invaluable to this dissertation.

To Elissa Haddad, Svetlana Krasynska, Dominika Bukalova, and Sue Carter Kahl, your extra doses of encouragement and support along the way and helping me to see the big picture, and the finer points, when I needed them the most.

To my committee chair, Hans Peter Schmitz, thank you for teaching me so much about how to be the kind of instructor who brings out the best in students. And, I have always valued your direct, German style approach. 
Also, to my committee members, Afsaneh Nahavandi and Marcus Lam. Afsaneh, I truly appreciated your voice of reason and your belief in me. Marcus, thank you for helping me focus on the details.

I owe so much to Pat Libby for her vision of a nonprofit institute to develop nonprofit talent and organizations through rigorous academics and for raising the profile of nonprofits in San Diego County. Her collaborative nature is something I will always admire and her continual belief in me as a nonprofit professional and person is something I will always treasure.

A heartfelt thank you goes to my dear friends, Glenda Blair, Jane Goodell, Rachel Bringleson, Susan Lowary, Monika Walther, and Rhonda Evans, and to my Barabbas Road Church family, who continually prayed for me during this endeavor,.

My immediate family deserves a special acknowledgement, especially my husband and best friend Eric who I love and admire, as well as my three children. Although they did not relish the idea that I could not attend special events and participate in family activities, they supported me relentlessly and are thrilled that I am done! I am truly blessed to have so much love and support.

I would be remiss if I did not acknowledge the many lessons I learned during this process. The old saying, "If I knew then what I know now" is so true. But, despite the mistakes that you as the reader might find, I look forward to developing this study into useable, practical tools to support the nonprofit sector. However, if you do find mistakes, or would like to discuss this dissertation with me, I welcome your engagement. Please contact me at crystaltrull@ sandiego.edu. 
And finally, I wholeheartedly acknowledge that this journey was more than just about getting my PhD. It was a process, ordained by God, that changed me to be more of the person He wants me to be and to rely on Him, more than own ability. For that I am forever grateful. 


\section{Table of Contents}

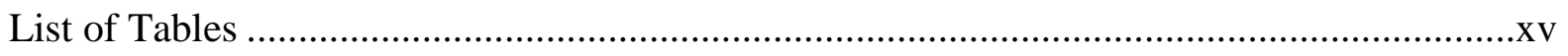

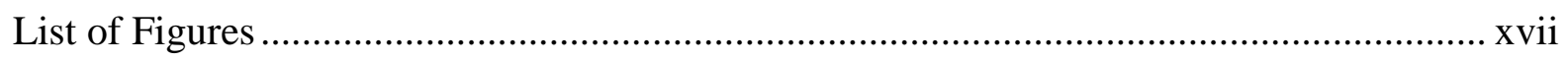

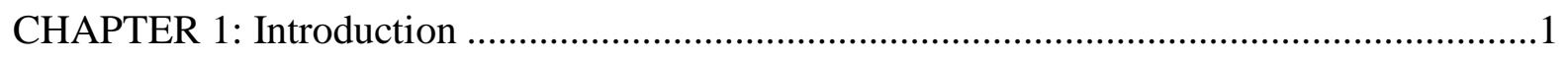

The Challenges of Studying Nonprofit Governance..........................................................2

The Importance of Studying Nonprofit Governance Legal Accountability ........................... 3

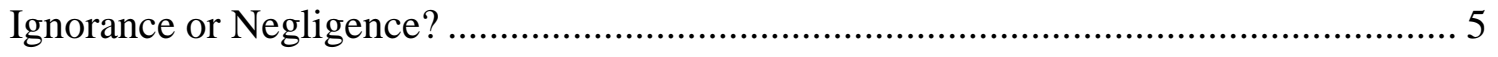

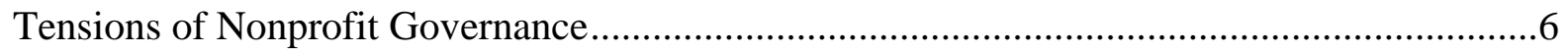

The Voluntary Nature of Nonprofits...................................................................... 7

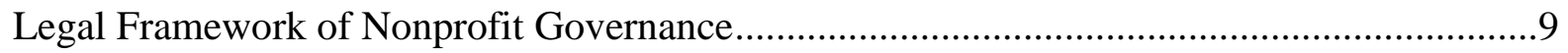

The Fiduciary Duties of Care, Loyalty, and Obedience .......................................... 10

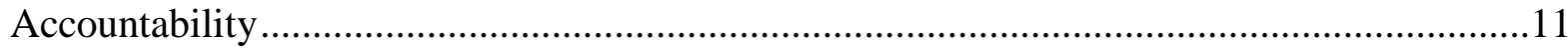

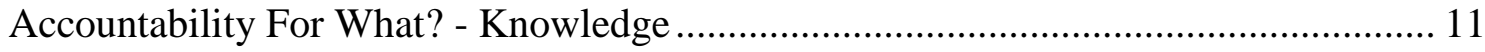

Accountable How? - Appropriate Sources of Knowledge ....................................... 12

Accountable To Whom? - Performance of Fiduciary Duties..................................... 13

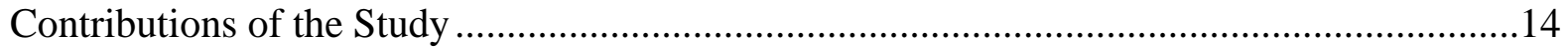

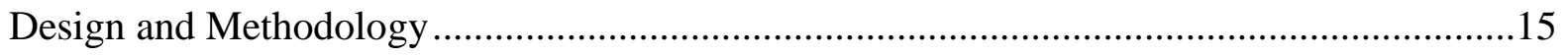

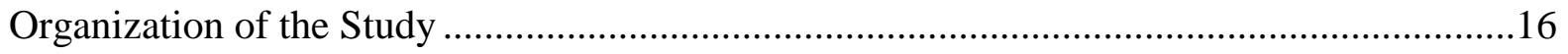

CHAPTER 2: Background, Research Design and Methods .............................................19

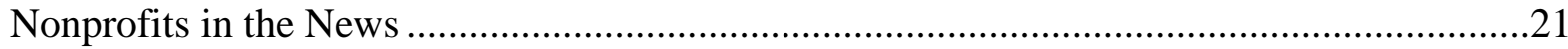

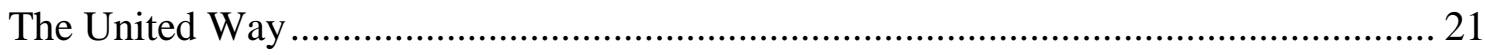

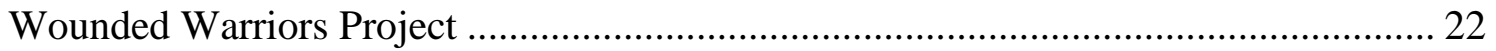

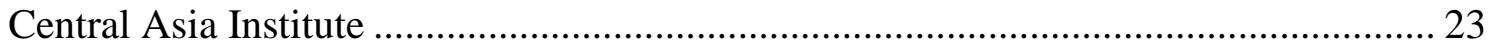

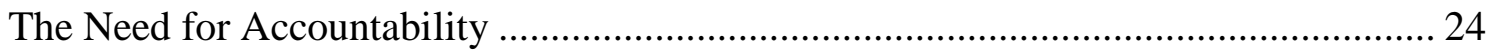

Nonprofit Structure and Legal Requirements for Governance ........................................25

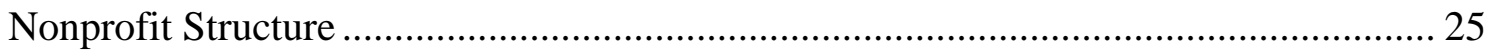

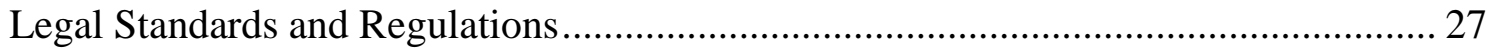

Fiduciary Duties of Loyalty, Care, and Obedience...................................................... 28

Nonprofit Leaders: Board Members and Executives .................................................. 29

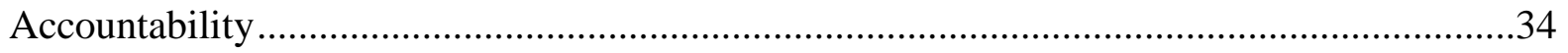

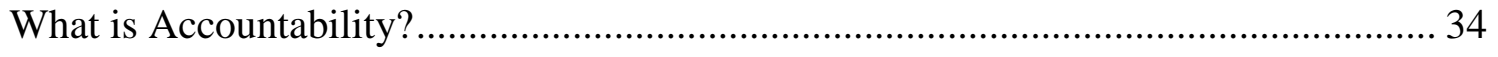

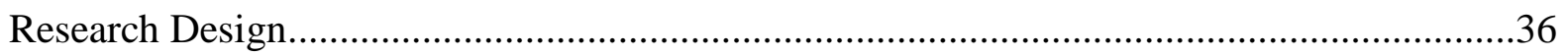

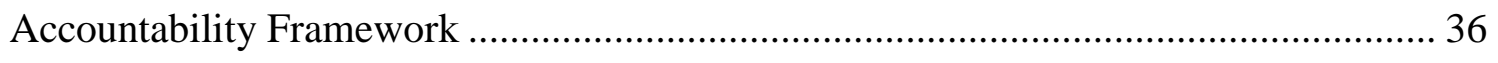

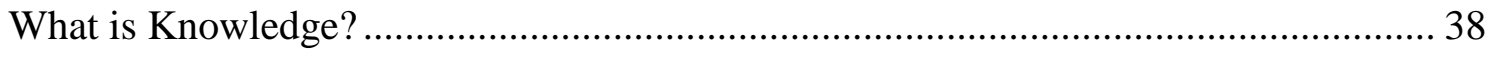




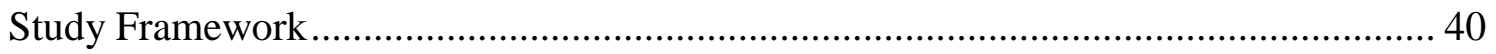

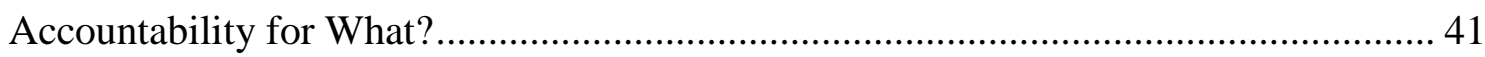

Accountability for What? Knowledge …………………....................................... 44

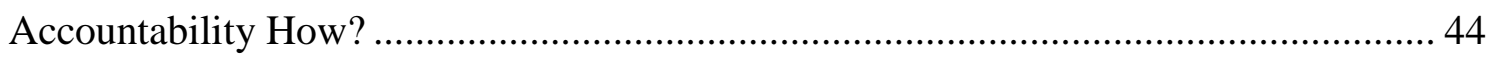

Accountability How? Source of Knowledge ……………............................................ 45

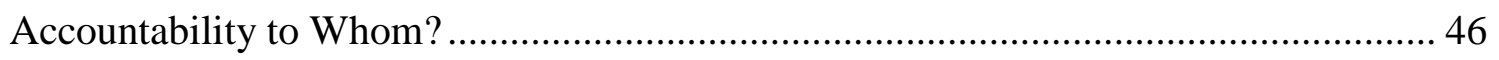

Accountability to Whom? Application of Knowledge ................................................... 47

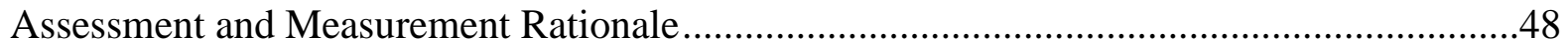

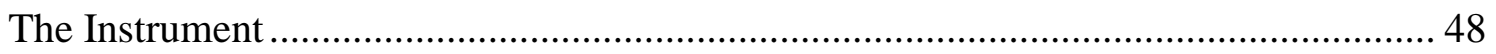

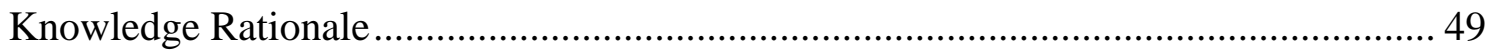

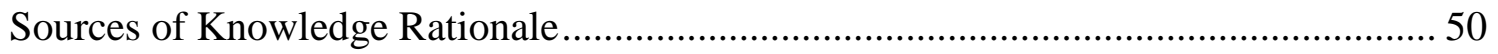

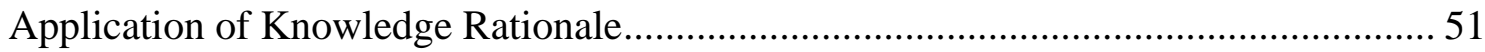

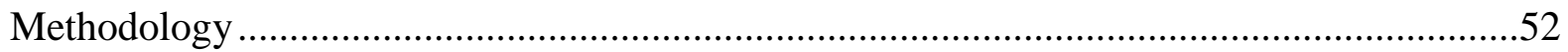

Sample

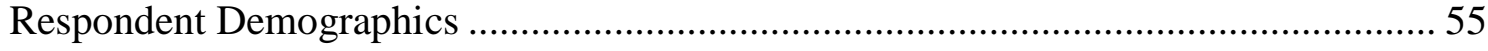

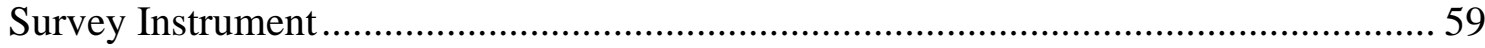

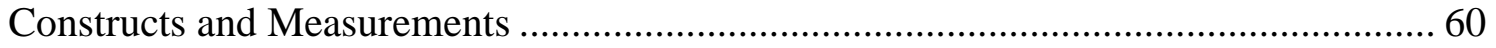

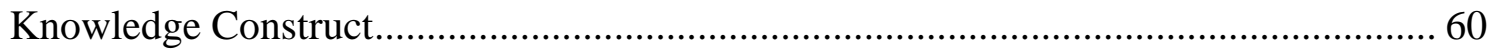

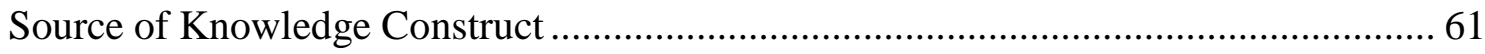

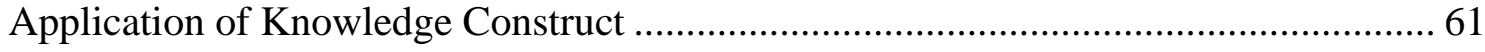

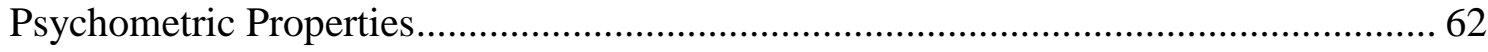

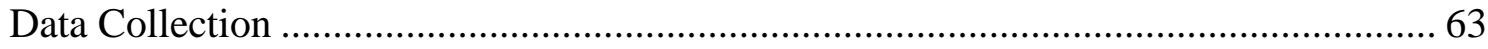

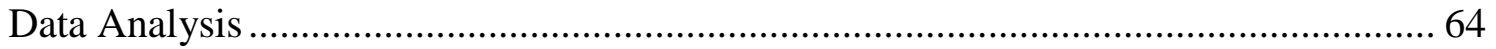

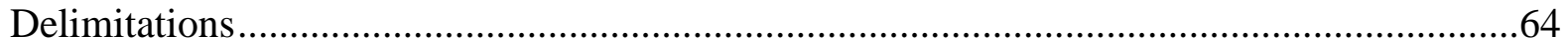

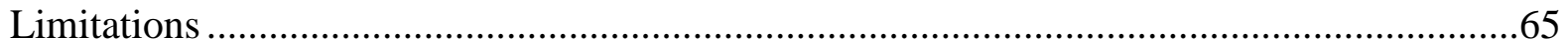

CHAPTER 3: Knowledge of Fiduciary Duties .................................................................68

Accountability for What?.............................................................................................

Nonprofit Characteristics and Legal Roots ......................................................................

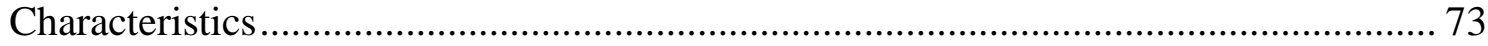

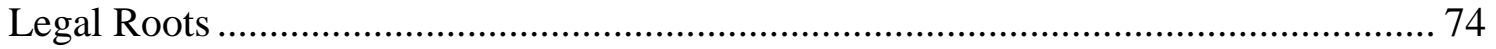

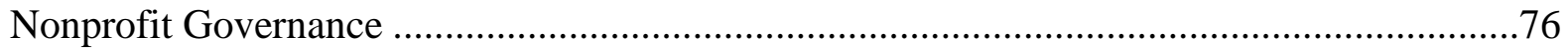

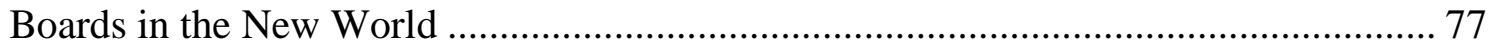

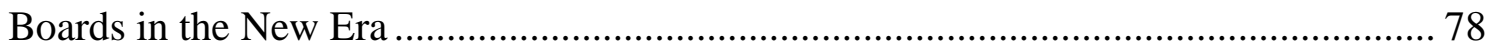

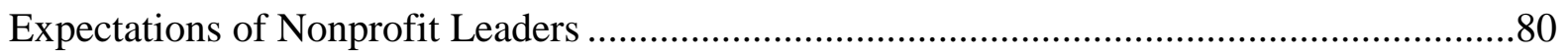




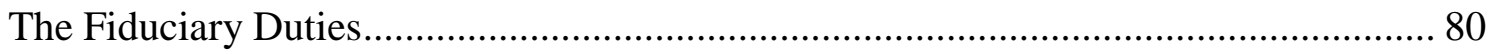

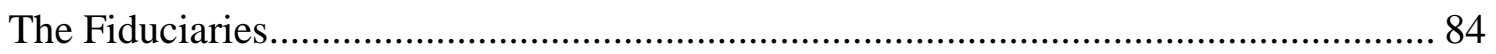

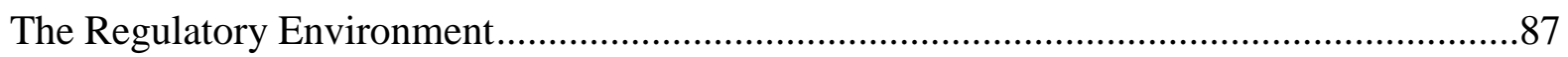

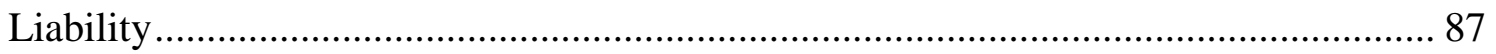

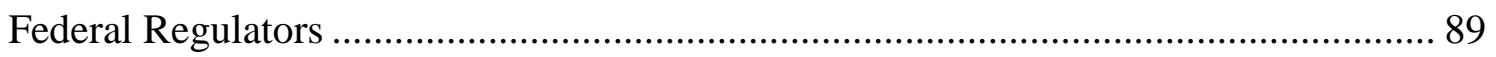

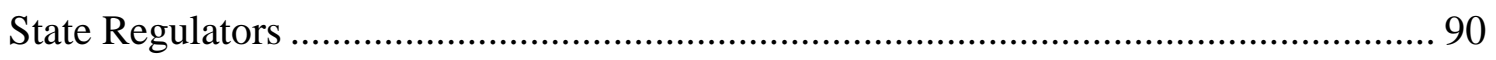

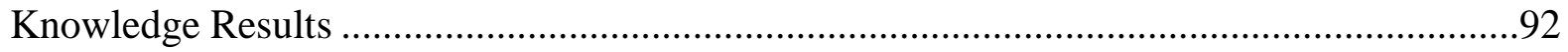

Self Reported Knowledge .................................................................................. 92

Results: Familiarity and Understanding by Role …………......................................... 93

Results: Familiarity and Understanding by Board Service........................................... 95

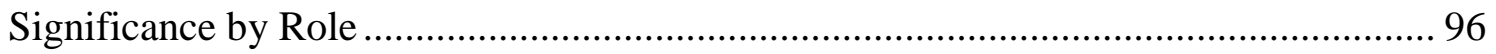

Significance by Board Service.......................................................................... 98

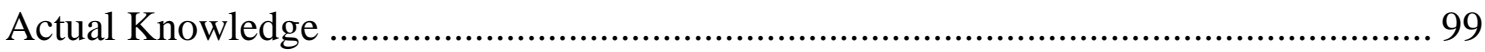

Actual Knowledge of Each Duty ............................................................................. 108

Familiarity vs. Actual Knowledge ......................................................................... 110

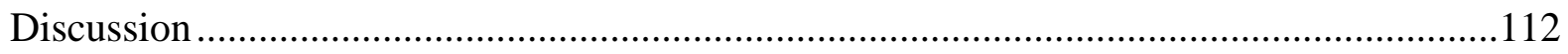

The Gaps: Familiarity with Duties and Actual Knowledge..................................................112

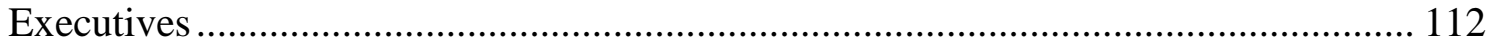

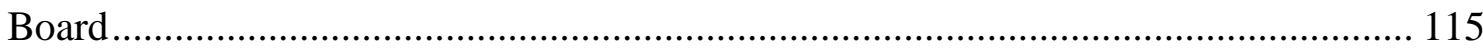

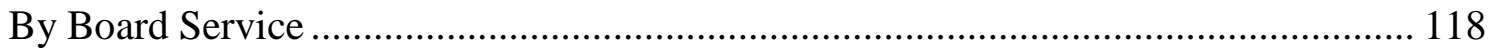

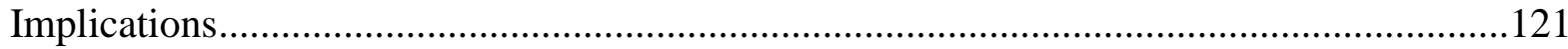

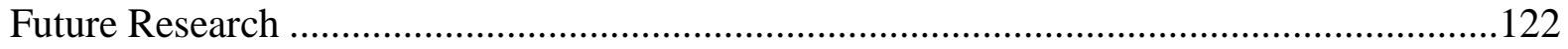

CHAPTER 4: Source of Fiduciary Duty Knowledge …….................................................123

How Nonprofit Leaders Learn About Their Fiduciary Duties.................................................123

External Dynamics, Demands, and Pressures.................................................................126

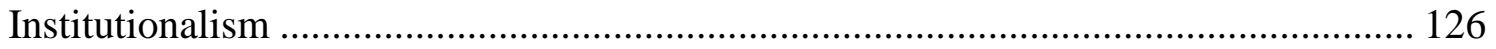

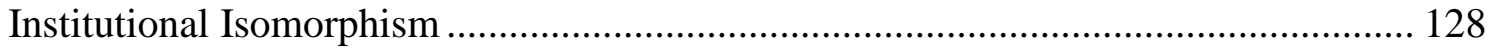

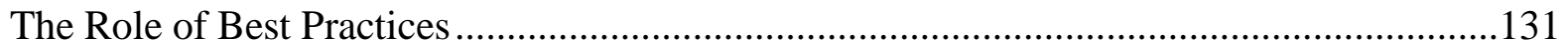

Accessing Knowledge to Meet Demands and Pressures ......................................................133

Sources of Fiduciary Knowledge - Results.......................................................................134

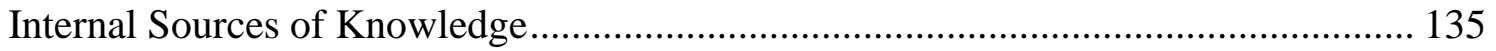

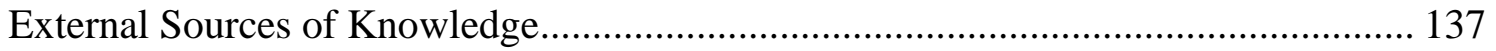

Sources and Actual Knowledge ………………………................................... 148

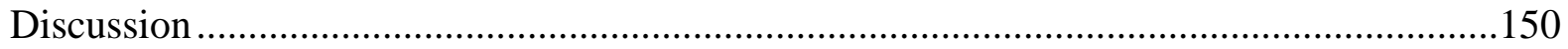




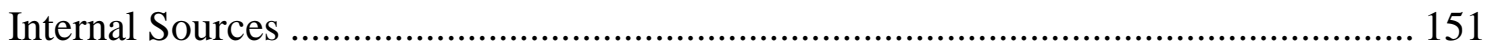

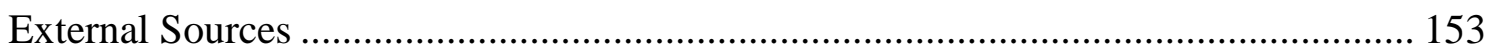

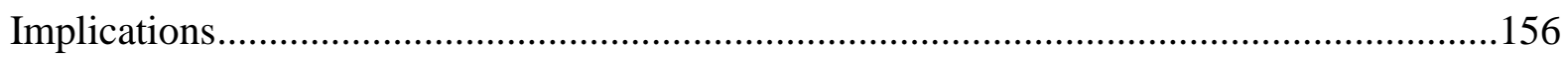

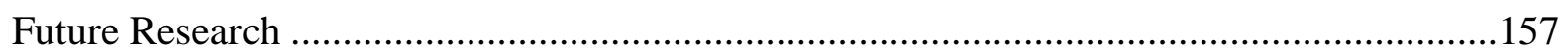

CHAPTER 5: Application of Fiduciary Duty Knowledge ................................................159

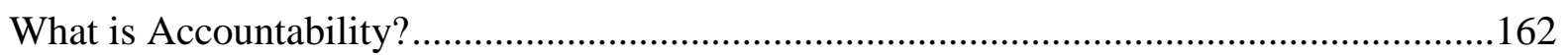

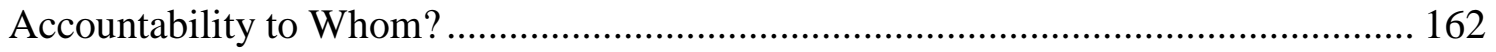

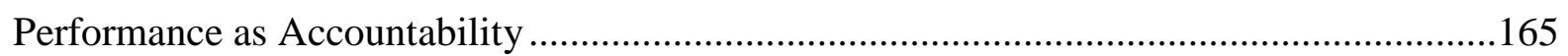

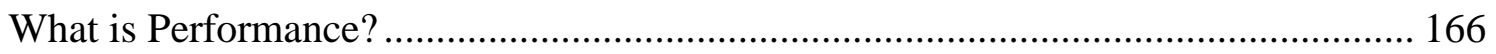

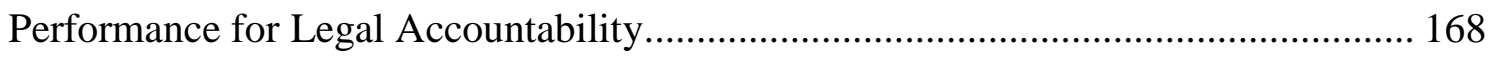

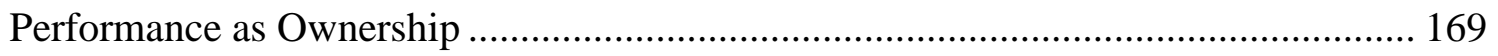

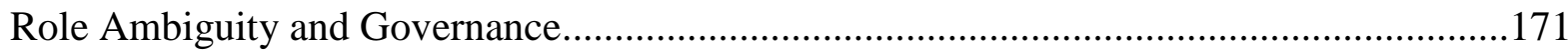

What We Know About Nonprofit Leaders ................................................................ 173

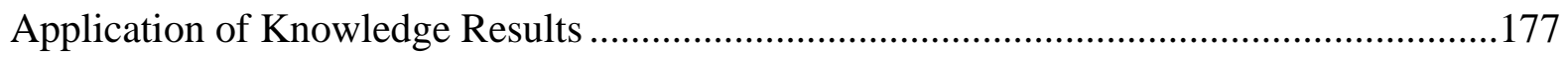

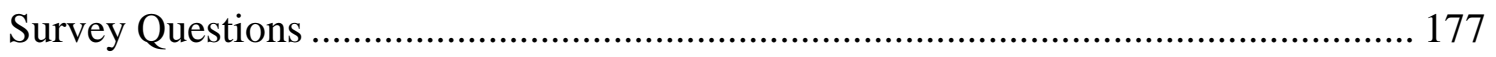

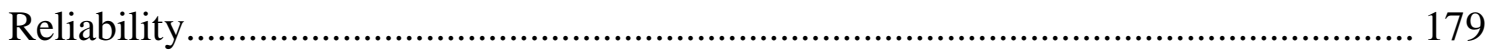

Application Results .......................................................................................... 181

Application of Duties and Actual Knowledge ……................................................... 182

Application of Duties and Actual Knowledge ………….......................................... 183

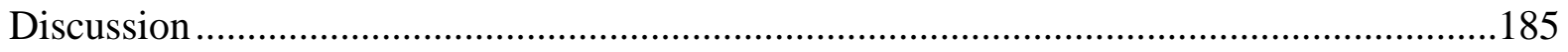

The Gaps: Application of Duties and Actual Knowledge ............................................ 185

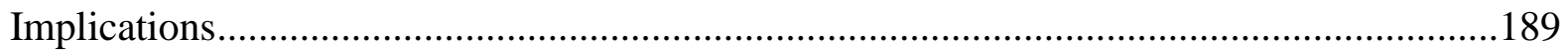

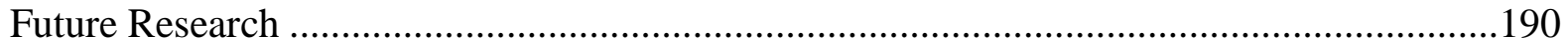

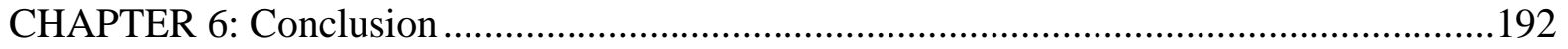

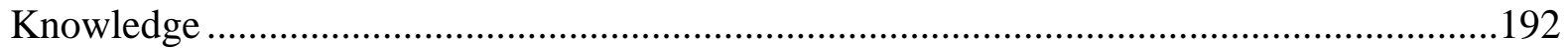

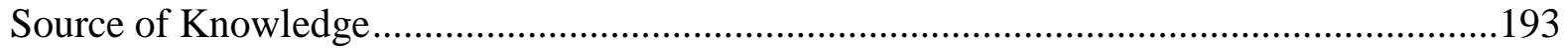

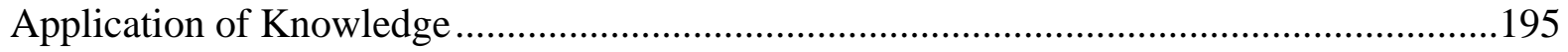

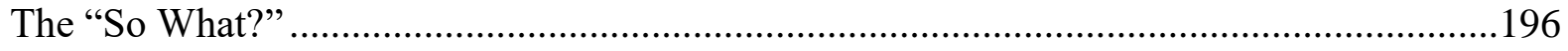

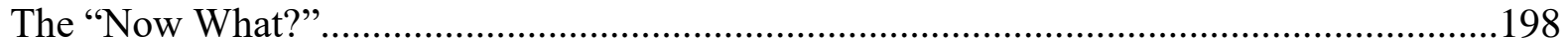

Connecting Research to Practice ………………….................................................. 198

Challenges and Opportunities ............................................................................... 199

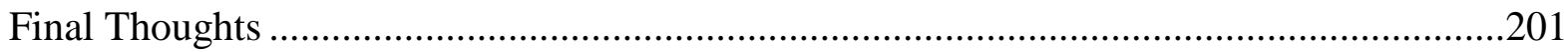

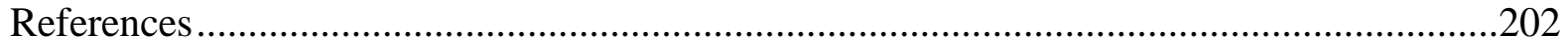

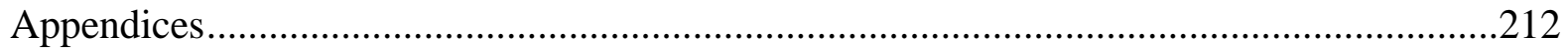




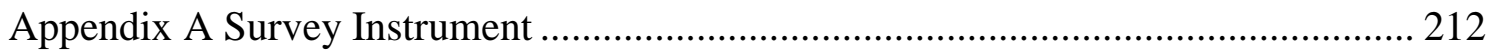

Appendix B Email Invitation to Participate in Study ............................................... 213 


\section{List of Tables}

Table 2.1 Nonprofit Leader Fiduciary Duty Responsibilities...............................................29

Table 2.2 Prescribed Board Responsibilities Related to Fiduciary Duties ...............................31

Table 2.3 Focus of Questions Related to Knowledge of Duties of Care, Loyalty, and

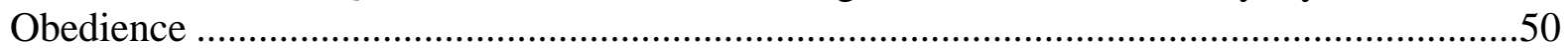

Table 2.4 Types of Internal and External Best Practice Sources ...........................................50

Table 2.5 Questions Related to Frequency of Application of Duty of Care, Loyalty, and

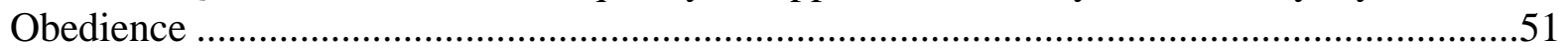

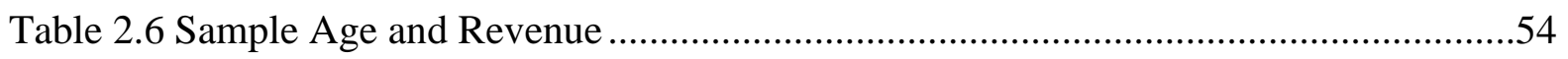

Table 2.7 Average Amount of Time to Take Survey..........................................................60

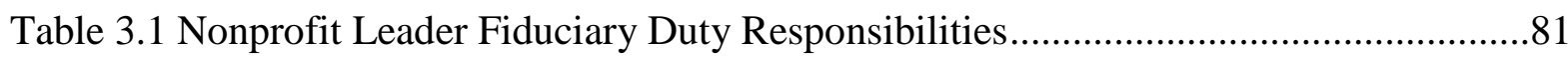

Table 3.2 Descriptive Data for Familiarity of Fiduciary Duties for All Roles .........................93

Table 3.3 Descriptive Data for Means of Familiarity of Fiduciary Duties for Board

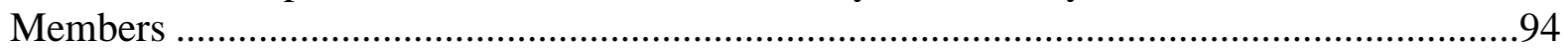

Table 3.4 Descriptive Data for Means of Familiarity of Fiduciary Duties for Executives......94

Table 3.5 Descriptive Data for Overall Understanding of Fiduciary Responsibilities by

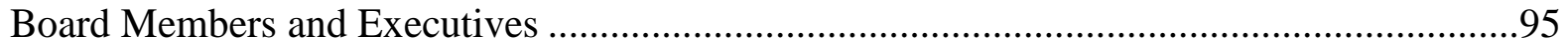

Table 3.6 Descriptive Data of Nonprofit Leader Familiarity of Fiduciary Duties by Board Service.

Table 3.7 Independent-sample t-Test Descriptive Data and Analysis for the Familiarity of Duties of Care, Loyalty, and Obedience by Role . .97

Table 3.8 Independent-sample t-Test Descriptive Data and Analysis for the Familiarity of

Duties of Care, Loyalty, and Obedience by Board Service.

Table 3.9 Descriptive Data for Passing Score of Actual Knowledge of Legal

Responsibility by Role 100

Table 3.10 Questions and Descriptive Data about Legal Responsibilities by All Roles.......102

Table 3.11 Questions and Descriptive Data about Legal Responsibilities by Role... 104

Table 3.12 Descriptive data for passing score of actual knowledge of legal responsibility by board service 105

Table 3.13 Questions and Descriptive Data about Legal Responsibilities by Board Service 107 Table 3.14 Percentage of Actual Knowledge of Fiduciary Duties by role 108

Table 3.15 Percentage of Actual Knowledge of Fiduciary Duty by board service 109

Table 4.1 Internal and External Best Practices Resources 135

Table 4.2 Descriptive Data for Percentages of Types of Internal Sources Nonprofit Leader Access by Role... 
Table 4.3 Descriptive Data for Percentages of Type of Internal Sources Nonprofit Leader

Access by Number of Boards Served

Table 4.4 Descriptive Data for External Sources for Fiduciary Duty Knowledge for All

Respondents ....

Table 4.5 Descriptive Data for Frequency of Access of External Sources to Learn about

Fiduciary Responsibilities by All Roles 138

Table 4.6 Descriptive Data for Frequency of Access of External Types of Sources to Learn about Fiduciary Responsibilities by Board Service

Table 4.7 Descriptive Data for Frequency of Access of External Sources to Learn about Fiduciary Responsibilities by Roles.

Table 4.8 Descriptive Data for Frequency of Access of External Types of Sources to Learn about Fiduciary Responsibilities by Number of Boards .

Table 4.9 Percentage External Website Source by Number of Boards Served and Frequency.

Table 4.10 Percentage External Webinar Source by Number of Boards Served and Frequency.....

Table 4.11 Percentage External Print Media Source by Number of Boards Served and Frequency.

Table 4.12_Percentage External Networks Source by Number of Boards Served and

Frequency.

Table 4.13 Percentage External Certificate and Degree Programs Source by Number of Boards Served and Frequency

Table 4.14 Descriptive Data for Nonprofit Leaders with a Passing Score for Knowledge and the Type of Internal Sources Access by Role

Table 4.15 Descriptive Data for Nonprofit Leaders with a Passing Score for Knowledge and the Type of Internal Sources Access by Board Service .....

Table 5.1 Prescribed Board Responsibilities Related to Fiduciary Duties

Table 5.2 List of Survey Questions Categorized by Duty and Measurement.

Table 5.3 Descriptive Data for Frequency of Application of Duty of Care for Board Members

Table 5.4 Descriptive Data for Frequency of Application of Fiduciary Duties for Executives

Table 5.5 Descriptive Data for Frequency of Application of Duties of Care, Loyalty, and Obedience for the Board

Table 5.6 Descriptive Data for Frequency of Application of Duties of Care, Loyalty, and Obedience for Executives .

Table 5.7 Summary of Pearson's r Correlation for Nonprofit Leaders with Passing Fiduciary Knowledge and the Application of the Duties of Care, Loyalty, and Obedience .183 


\section{List of Figures}

Figure 2.1. Legal Accountability Process ........................................................................36

Figure 2.2. Framework for Legal Accountability adapted by Ebrahim (2010) The many

faces of nonprofit accountability. 37

Figure 2.3. Miller's Framework for Clinical Assessment. Reprinted from The assessment of clinical skills/competence/performance, Academic Medicine (1990). ..............................39

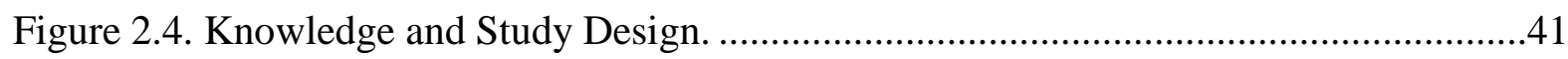

Figure 2.5. Framework for Legal Accountability. ...........................................................48

Figure 2.6 Sample percentages by sub-sector for organizations who provided identifying

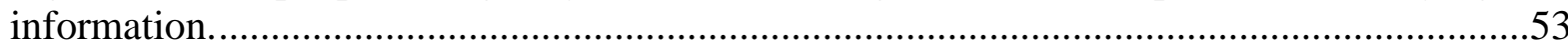

Figure 2.7. Percentages of respondents by two roles $(\mathrm{N}=184)$ and three role categories $(\mathrm{N}=184)$.

Figure 2.8. Percentages of respondents by board role $(\mathrm{N}=186)$.......................................58

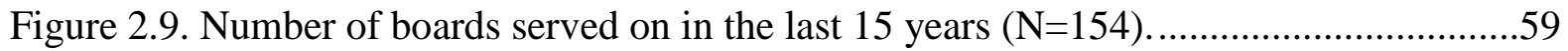

Figure 3.1. Framework for Legal Accountability. ......................................................69

Figure 3.2. Constructs and Legal Accountability adapted from Miller's framework for clinical assessment model in The assessment of clinical skills/competence/performance,

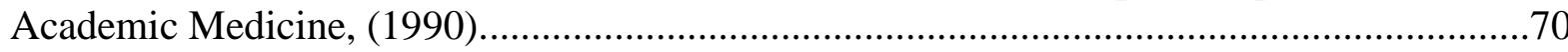

Figure 3.3. Means of nonprofit leader familiarity of fiduciary duties by role .......................94

Figure 3.4. Means of nonprofit leader familiarity of fiduciary duties by board service.........96

Figure 3.5. Percentage of nonprofit leader actual knowledge of fiduciary care, loyalty, and obedience by board service

Figure 3.6. Percentage of nonprofit leader actual knowledge of fiduciary care, loyalty, and obedience by board service

Figure 3.7. Means of familiarity of duty of care, loyalty, and obedience compared to the percentage of actual knowledge of overall fiduciary care, loyalty, and obedience for board members.

Figure 3.8. Means of familiarity of duty of care, loyalty, and obedience compared to the percentage of actual knowledge of overall fiduciary care, loyalty, and obedience for executives

Figure 4.1. Framework for Legal Accountability.

Figure 4.2. Constructs and Legal Accountability.

Figure 4.3. Means for Frequency of Access of External Sources Types of Sources to Learn about Fiduciary Responsibilities by All Role and All Boards Served. 139

Figure 4.4. Means for Frequency of Access of External Sources Types of Sources to Learn about Fiduciary Responsibilities by All Role. 
Figure 4.5. Means of Frequency of Access of External Types of Sources to Learn about

Fiduciary Responsibilities by Number of Boards.

Figure 4.6. Percentage of Nonprofit Leaders with a Passing Score for Knowledge and the Type of Internal Sources Access by Role.

Figure 4.7. Percentages for Nonprofit Leaders with a Passing Score for Knowledge and the Type of Internal Sources Access by Board Service...................................................150

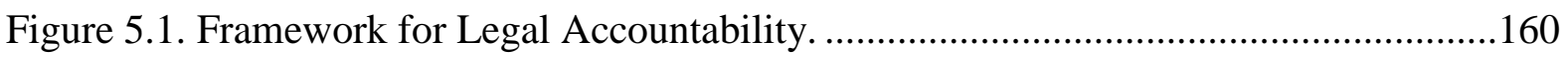

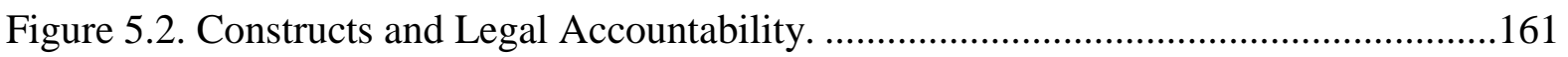

Figure 5.3. Means of application of duty of care, loyalty, and obedience compared to the percentage of actual knowledge of overall fiduciary care, loyalty, and obedience for board members.

Figure 5.4. Means of application of duty of care, loyalty, and obedience compared to the percentage of actual knowledge of overall fiduciary care, loyalty, and obedience for executives. 


\section{CHAPTER 1: INTRODUCTION}

Nonprofits are woven into the very fabric of American life. On any given day, in nearly every community across the United States, people interact with the more than 1.5 million charitable organizations that provide a variety of programs and services (National Center for Charitable Statistics, 2019). Nonprofits enrich our lives socially as well as provide critical services that many people depend on. Nonprofits also significantly contribute to the national economy by generating more than $\$ 1.74$ trillion in revenues and by employing more than 12.3 million people (United States Department of Labor, 2018; National Center for Charitable Statistics, 2018).

Many stakeholders rely on nonprofits and as such, hold nonprofits accountable to carry out their respective missions. As the governance body, boards of directors and the chief executive are legally responsible to uphold federal and state mandated fiduciary duties designed to ensure that organizational resources (financial, human, physical, and intellectual) are used in a manner that fulfills the charitable mission. However, over the years we have seen many cases of resources used for purposes other than to fulfill the mission. Cases of excessive compensation, conflict of interest, lack of oversight, and intentional wrongdoing have been reported in nonprofits of all sizes and that carry out a variety of missions. For the cases that are reported, findings often point to boards of directors and executives not fulfilling their oversight and management duties either because of ignorance, lack of engagement, or conflict of interest.

Nonprofit leaders are held to high standard of conduct. When stories of nonprofit mismanagement and negligence come to light nonprofits are impacted in a variety of ways: The public becomes wary of nonprofits, donations decline, reputations suffer and 
ultimately the mission goes unfulfilled. Yet, the high profile cases highlight what goes unreported: the countless nonprofit boards and executives, across the nation, leading and managing nonprofits of all shapes and sizes, failing to fulfill their oversight management and role. Weak board oversight is an endemic issue that ultimately negatively affects those who rely on the goods and services when resources are wasted and the mission goes unfulfilled.

\section{The Challenges of Studying Nonprofit Governance}

Studying nonprofit governance, in terms of legal accountability, is actually more challenging than one may think. Nonprofit leaders are expected to fulfill their fiduciary duties and are held legally responsible by federal and state agencies. Yet, reports from regulators lag by several years, because of privacy rights and lack of resources. Furthermore, when information is made available, it is difficult to tease out the specifics of the instances or identify penalties or outcomes of the investigations and inquiries. The Internal Revenue Service (IRS) releases annual reports about nonprofits that have had their tax-exempt status revoked, but no information is made available about how many nonprofits were investigated or the basis for the investigation.

When nonprofits are found to have failed in upholding their fiduciary duties, they are fined and asked to institute recommendations to support good governance. The ultimate penalty nonprofits face for failure to uphold their fiduciary duties is tax exempt revocation, however, when the IRS releases how many tax exempt organizations were revoked, there is no indication as to what caused the revocation. Was it simple negligence such as failing to file required reports? Was it intentional criminal activity? Or, was it because of the zone of insolvency-when the organization is no longer financially stable? 
Although the public is aware of the cases that receive media attention, this type of negligence is more common throughout the nonprofit sector. Anecdotally, as a practitioner for the past 20 years with experience in all levels of nonprofit organizations as an executive, program staff, board member, and consultant, I have interacted with countless organizations who struggle with governance issues. What seems to be a common thread is that they do not understand, or in some cases are aware of, their basic fiduciary duties. For these organizations, their lack of knowledge may not end up in the news, but rather is the basis for potentially negative consequences related to poor decision-making and lack of engagement.

Furthermore, in my work as a nonprofit consultant, I have helped many organizations regain their tax exempt status due to their lack of legal compliance which for some, resulted in their tax status revocation. In all cases, the board expressed that they did not know about the reporting requirements and if they knew, they would have done what was required. I have often thought that this issue is ripe for research in order to better understand where, how, and why governance failures may be happening.

\section{The Importance of Studying Nonprofit Governance Legal Accountability}

Leading and managing a nonprofit organization has become increasingly more complex with the increased demand for services and competition for resources. And, as more and more cases of nonprofit mismanagement and wrongdoing are reported, important questions about legal accountability are raised for the nonprofit sector and for academics. Do nonprofit leaders understand their fiduciary duties? Do nonprofit leaders have access to appropriate trainings and tools to learn about their fiduciary duties? Are the pressures for performance creating a culture that is more susceptible to negligence 
and ignorance because nonprofit leaders are focused more on financial sustainability than their mission?

To answer these important and urgent questions, this study explores the governance of nonprofits as a major factor driving accountability. While there is significant research on nonprofit governance, much of it prescribes that nonprofit leaders fulfill a variety of roles (Carver, 1997; Chait, Ryan, \& Taylor, 2005; Herman \& Renz, 2000; Holland \& Ritvo, 2008; Houle, 1997; Renz, 2010). However, there are very few studies focused on what nonprofit leaders know about their basic legal fiduciary responsibilities, specifically, 1) nonprofit leader knowledge of fiduciary duties, 2) the sources of their fiduciary knowledge, and 3) the application of such knowledge. This dissertation provides insights into these issues by collecting baseline data about nonprofit leader (board members and executive) knowledge of fiduciary duties, the sources they access in learning about their fiduciary duties, and application of fiduciary knowledge in the performance of their governance responsibilities.

As an academic, my goal is to research these issues empirically by developing an assessment tool, that others can build upon, that focuses on the basic responsibilities of nonprofit leaders as outlined in the fiduciary duties. As a practitioner, my goal is to strengthen nonprofit governance by identifying gaps in leader knowledge of fiduciary duties. As a pracademic (academic and practitioner), I believe that research in this particular area of nonprofit governance will help nonprofit leaders better understand their basic fiduciary duties, creating a solid foundation that supports sustainability and success for their organizations. 


\section{Ignorance or Negligence?}

There is limited empirical evidence about how boards actually function (Jackson \& Holland, 1998). Some of the literature on nonprofit governance tends to be theoretical and conceptual (Cornforth, 2012) while other literature is based on for-profit contexts and does not necessarily translate to the nonprofit sector. The literature can be prescriptive in describing how a nonprofit board should function based on a variety of factors (Miller, 2002; Ostrower \& Stone, 2006). For example, some studies have focused on overall leadership (Chait, et al, 2005), relationships between executive management and the board (Brown, 2005), and predictors of performance based on board configurations and composition (Bradshaw, 2009) while others are related to the characteristics of leaders (Riggio \& Orr, 2004) and management practices (Helmig, Jegers, \& Lapsley, 2004). Furthermore, there is a vast body of practitioner literature that provides "how to" advice for nonprofits who want to strengthen their boards, but it is usually based on what works for a select group of organizations or sub-sector.

Are nonprofit leaders acting out of ignorance or negligence? I offer that ignorance is more likely the root of the lack of fiduciary awareness amongst nonprofit leaders, based on my experience in the nonprofit sector. However, there is also an aspect of complacency that occurs in boardrooms across the country. Boards are relied upon for oversight of the organization, not involvement in the day-to-day. However, because many nonprofits are small, their board members take an active role in the daily operations of the organization. Larger organizations rely on their boards for more strategy, but as organizations grow so does their staff. As organizations recruit professional staff, the board becomes overly reliant on the executive and board members become complacent. 
Boards become complacent when they are not engaged (Chait, et al., 2005). Engagement is a key component to the fiduciary duty of care, but based on the results of this study, many nonprofit leaders are not aware that showing up to meetings and reviewing organizational documents prior to the meeting are legal responsibilities. Chait, et al. (2005) identifies this tension by differentiating between a board problem and a problem with the board. Board problems are things that are relatively easy to pinpoint such as lack of attendance at board meetings. Problems with the board are more subtle that typically include lack of purpose. In looking through a legal accountability lens, lacking the appropriate knowledge of fiduciary duties is both a board problem for the individual board members and a problem with the board given that the individual board members collectively make up the governance body and are the ones making decisions on behalf of the organization.

\section{Tensions of Nonprofit Governance}

Looking at the historical roots of how the U.S. nonprofit sector developed, several tensions exist today that create challenges in governing nonprofit organizations. Over time, the responsibilities for board members and executives have expanded that go above and beyond the basic fiduciary duties. Nonprofit leaders of the $21^{\text {st }}$ Century are expected to develop strategy, be community advocates, and raise awareness of their organization's mission while overseeing the organization as a whole. Additional roles create additional distractions, specifically in the expectation to be accountable to a variety of stakeholders, not just regulators. With more responsibilities and more stakeholders to appease, the legal responsibilities are often eclipsed. 
Another factor is the lack of a standardized process to ensure that nonprofit leaders understand their basic responsibilities. Without a standardized assessment, nonprofit leaders can be ignorant about their roles and responsibilities, specifically their fiduciary duties, and serve without consequence. Another factor is the voluntary nature of service. Because they are volunteers, nonprofit leaders are given a great deal of leeway for negligence. Combined, these issues have caused challenges in holding nonprofits accountable for governance and oversight.

\section{The Voluntary Nature of Nonprofits}

How nonprofits have evolved over time has impacted the evolution of nonprofit governance. Some have suggested that as the essential services became more privatized, Americans began to rely more heavily on nonprofits, creating "problematic gaps" that have become "more glaringly evident" in terms of accountability (Dobkin-Hall, 2003, p. 26). I offer that these gaps are a result of the convergence of the voluntary nature of nonprofits and the regulations concerning the use of public money for a public purpose.

The U.S. Tax Code requires that all corporate entities tax exempt or not, have a governance structure in place to make decisions on behalf of the corporation (Legal Information Institute, 2017). For private corporations this is often the shareholders, board of directors, or owner(s) who typically have a financial stake in the corporation and are given voting power and control of the firm. However, because nonprofit organizations resources cannot personally benefit individuals, nonprofits must be governed by disinterested parties who typically are volunteers. These individuals are tasked with the responsibility to ensure that nonprofit organization resources are available for and allocated to fulfill its charitable mission (IRS, 2017a \& 2017b). 
Referred to as boards of directors or trustees, these volunteers have either a connection to, or an alignment with, an organization's mission. As volunteers, board members bring with them a variety of skills and backgrounds to the organizations they serve. Collectively, these boards are held legally responsible, along with the chief executive who is typically paid staff, to ensure that organizational resources are used in a manner that fulfills a charitable purpose and to make decisions on behalf of, and to act in the best interest of, the organization. Furthermore, given the amount of responsibility that board members and executives have, one might assume that nonprofit leaders are adequately prepared to fulfill their roles and responsibilities. However, no standardized system exists to ensure that board members have the understanding of what they are legally responsible for or what their duties entail. And, although nonprofit board members are responsible for the financial and moral oversight, many boards lack awareness of what those responsibilities actually are (Wright \& Millesen 2008).

Given that board members are volunteers, they go about their roles in a different manner than paid employees (Miller \& Jablin 1991). Employees typically have some training and prior knowledge about their duties when they are hired. In fact, the prior knowledge and level of expertise may be the deciding factor for their employment. Yet, for board volunteers, there is no expectation of any prior experience (in this case, serving on a board), adequate knowledge, or the requirement of a specific skill set (unless sought after for financial, legal, or other expertise). Although the voluntary nature of nonprofits encourages participation for all, without any criteria for service, the old saying goes, "you get what you pay for". This leniency is reflected in a letter to the editor of the Chronicle of Philanthropy that raises red flags about the lack of standards for board service when 
they stated that, "the tendency is to 'make allowances' where non-profits are concerned, to give them 'the benefit of the doubt", which "always breeds trouble" (Gibelman \& Gelman, 2001, p. 62).

A national survey of nonprofit leaders reported that board chairs gave themselves an A- in understanding the organization's mission and a B in understanding their roles and responsibilities (BoardSource, 2017, p. 28 and 47). This dissertation is similar in that both board members and executives indicated that they were very familiar with the fiduciary duties, understood their organization's mission, and had enough knowledge to carry out their duties. Yet, the results of this dissertation highlight a gap between what nonprofit leaders believe they know about their fiduciary duties and what they actually know.

\section{Legal Framework of Nonprofit Governance}

As creations of United States federal and state legislation, nonprofits are corporate entities and must abide by federal and state laws and statutes. Nonprofits are differentiated from other types of corporate entities by how they are taxed and how profits are distributed. Nonprofits are tax exempt entities, which allow for public support, such as tax free revenues, government contracts, and charitable donations in exchange for providing a charitable, scientific, religious, or educational purpose that benefits the public. Because tax exempt entities are private corporate entities designed to generate a public benefit, they are prohibited from distributing profits (or any other organizational resource) to a select group of individuals, whereas for profit corporations are designed to generate wealth for individuals. However, all corporations, regardless of their corporate form, must have a governance body in place that ensures compliance with federal and 
state requirements and that acts as the decision-making body for the corporation. The governing body is referred to as a board of directors and for nonprofits, the governance body is responsible to ensure that resources are directed to fulfill a public, charitable purpose, not benefit a few individuals.

\section{The Fiduciary Duties of Care, Loyalty, and Obedience}

The duties of loyalty, care, and obedience are the legal fiduciary responsibilities of nonprofit leaders that board of directors and executives must adhere to. These responsibilities are tied to resources (physical, financial, human, and intellectual) and outline expectations of how nonprofit leaders will direct and use its resources to fulfill a tax exempt mission. The duties of loyalty, care, and obedience work together, however individually, they comprise specific aspects of nonprofit leader fiduciary responsibilities.

The duty of care relates to how much a nonprofit leader engages in the organization they are responsible for governing (Hopkins, 2009). Specific activities that fall under this duty include: attending board and other relevant governance meetings, reviewing information in advance of meetings, considering all information before voting (including executive staff performance, finances, and internal policies), and exercising independent judgment. The duty of loyalty requires nonprofit leaders to put the interests of the organization above their own personal interests (Hopkins, 2009). Specific activities that fall under this duty include: disclosing conflict of interest, maintaining confidentiality of organizational information, and ensuring that organizational resources are not used for personal gain. The duty of obedience focuses on compliance (Hopkins, 2009). Nonprofit leaders that are fulfilling their fiduciary duty of obedience adhere to all laws, at all levels (e.g. federal, state, county, city). Specific activities that fall under this 
duty include: abiding by organizational bylaws, submitting required documentation as needed such as an annual tax return and, ensuring that all decisions fall within organizational policies and fulfill the tax exempt mission.

\section{Accountability}

Nonprofits are held accountable by a variety of stakeholders: clients, donors, staff, and regulators all are invested in the work of nonprofits. Given the many faces of accountability, this study focuses on one aspect, legal accountability, which is bounded by what nonprofit leaders are legally accountable for. As such, the fiduciary duties of care, loyalty, and obedience serve as the foundation for this research.

Ebrahim (2010) provides a useful accountability framework that is used in this study. He offers that organizations can better meet accountability demands when they decide what they are accountable for, how they are accountable, and to whom they are accountable. Because legal accountability is the focus of this study, each facet of accountability is addressed. Nonprofit leaders are legally accountable to know what their fiduciary duties are. How they meet legal accountability is through accessing the appropriate sources of knowledge to learn about their fiduciary duties. And, finally, to whom nonprofit leaders are accountable to are regulators by meeting legal accountability in the performance of their fiduciary responsibilities.

\section{Accountability For What? - Knowledge}

In order to satisfy legal accountability, nonprofit leaders must know what their fiduciary responsibilities are, which in turn, serves as a foundation for their governance activities. In today's nonprofit, leaders are asked to do more than just oversee. It seems that in the past few decades, board governance has expanded from basic fiduciary duties 
to expectations that a super hero would have difficulty meeting. Boards are asked to plan for the future by setting strategy and casting vision for the organization; be informed about external shifts, legislation, and local impacts on their mission; build relationships with a variety of stakeholders; and to assess effectiveness while promoting accountability (Carver, 1997; Chait, Ryan, and Taylor, 2005; Holland \& Ritvo, 2008; Kearns, 1996; Renz, 2010). At first glance, these responsibilities would seem feasible given that most boards are often made up of accomplished professionals in their fields. Yet, there is evidence that, regardless of their professional acumen, many board members have little to no experience in the governance aspects of running a nonprofit (Preston \& Brown, 2004).

The lack of understanding and experience is a wide spread issue. Two wellregarded national studies on board governance, Leading with Intent (BoardSource, 2017) and the Stanford Survey on Leadership and Management in the Nonprofit Sector (Stanford, 2017) provide evidence about the absence of governance knowledge among nonprofit leaders. Leading with Intent reports that board members and executives give themselves a ' $\mathrm{B}$ ' when asked to assess their own understanding of board roles and responsibilities. When asked about the top challenges facing the nonprofit sector as a whole today, nonprofit board members and executives ranked "weak or ineffective board governance" in the top three (Stanford, 2017, p. 13).

\section{Accountable How? - Appropriate Sources of Knowledge}

In order to satisfy legal accountability, nonprofit leaders must access the appropriate sources of fiduciary knowledge in order to carry out their governance duties. Institutionalism (Scott, 2008) suggests that organizations primarily respond to their external environments in order to gain and maintain legitimacy. Processes of coercive, 
mimetic, and normative isomorphism (DiMaggio \& Powell, 1983) explain how organizations adopt new practices. Nonprofits may be directly pressured by donors (coercive) to change course, they may seek out new answers under conditions of uncertainty (mimetic), or they may change as a result of the professionalization of their staff (normative).

Best practices are often a means for nonprofit leaders to satisfy legal accountability. Best practices are widely accepted standards developed by nonprofit practitioners, scholars, and academics to support various aspects of leading and managing nonprofit organizations. For many organizations, best practices fill the void of a missing standardized assessment process and become a substitute in efforts to meet demands for legal accountability.

\section{Accountable To Whom? - Performance of Fiduciary Duties}

In order to satisfy legal accountability, nonprofit leaders must apply their fiduciary knowledge in the performance of their governance duties. Following the rules is the first step in meeting demands and expectations of the various stakeholders that nonprofits interact with. Since nonprofit leaders are held legally responsible for their decisions, knowing what the fiduciary responsibilities are is critical for any nonprofit leader. But reality is far from this ideal, as "boards make decisions based on incomplete information, rushed circumstances, gut feelings and experiences rather than the formalized method of decision making that the legal model suggests" (Fishman, Schwartz \& Mayer, 2015, p. 114). Board complacency "appears to be the norm, and action the exception" (Holland, 2002, p. 422). These problems suggest a need to "move the measurement of board member performance from one that has typically focused on 
quantity to one that focuses on the quality of individual contributions to the board" (Doherty \& Hoye, 2011 p. 110).

\section{Contributions of the Study}

If nonprofit leaders have limited or inaccurate knowledge of their basic fiduciary responsibilities, how are they expected to govern, let alone fulfill many of the other expectations placed on them for the sustainability of their organizations? Given that the literature is scarce concerning what nonprofit leaders actually know about their basic fiduciary responsibilities further exploration of this important aspect of management and governance is needed. More specifically, research about nonprofit leader knowledge of their fiduciary duties.

As such, this study contributes to both the scholarly and practitioner fields. In terms of scholarly contributions, the study is the first of its kind. It pilots an assessment tool designed to establish baseline data about the fiduciary duties of care, loyalty, and obedience that tax exempt boards of directors and executives must fulfill in order to satisfy legal accountability. Furthermore, the study is focused on individual nonprofit leaders: what they know, sources of their knowledge, and the application of knowledge in the performance of their fiduciary duties.

In terms of practitioner contributions, the results of this study identify gaps in nonprofit leader knowledge of their fiduciary duties that can be used to educate nonprofit leaders, funders, and regulators. The education would focus on how best to address specific areas of governance through trainings and other means in order to strengthen nonprofit governance. Furthermore, the assessment tool developed for this study fills a gap that exists in currently available assessment tools, because it focuses on the legal 
aspects of nonprofit oversight, specifically the fiduciary duties of care, loyalty, and obedience.

\section{Design and Methodology}

Based on the purpose of this study, quantitative methods were utilized. Inductive descriptive statistics, correlation analysis, and hypothesis testing were performed using the individual (board member and executive) as the unit of analysis. From this point on, nonprofit leader is the term that will be used to describe board members and executives. An online survey, developed for this study, was the primary means of data collection. Legal accountability in governance is the overarching focus of this study that utilizes the three facets of accountability: 1) for what nonprofit leaders are legally accountable, 2) how nonprofit leaders meet legal accountability, and 3) to whom nonprofit leaders are legally accountable. The purpose for using this framework is to operationalize how accountability is expressed as legal accountability via the fiduciary duties of care, loyalty, and obedience. Nonprofit leader knowledge of fiduciary duties, the source of their fiduciary knowledge, and the application of their fiduciary knowledge in the performance of their governance duties are the constructs based on specific aspects of the fiduciary duties. Although each duty represents a specific aspect of oversight, they are connected and work together. 


\section{Organization of the Study}

The aim of this study is to provide empirical research that is useful to practitioners and academics and that is applied and theoretical. Ultimately, as a practitioner, I am particularly interested in exploring the gaps in governance that I experience regularly in the sector. As an academic, I am interested in developing an assessment tool that can be tested further to provide insight into the gaps nonprofit leaders have related to their fiduciary responsibilities.

The premise of this study is that nonprofit leaders who understand their basic legal fiduciary duties can perform their fiduciary duties and consequently satisfy legal accountability demands. This dissertation is organized around three separate studies, preceded by an extensive background and methodology chapter (chapter two) that applies to each of the three articles, to avoid redundancies across the articles. The chapters are designed to be stand-alone scholarly pieces to submit to academic journals and practitioner publications.

Chapter two provides context in order to lay the groundwork for the purpose of this study. Accountability is explored in greater detail along with how the study addresses the three facets of accountability: for what, how, and to whom. In addition, details about the methodology, limitations, and definitions are included.

Chapter three focuses on nonprofit leader self reported and actual knowledge as a means to satisfy legal accountability for what. The focus is on the first strand of research, nonprofit leader (board members and executives) knowledge of fiduciary responsibilities as a means to meet legal accountability. The chapter also discusses the nature of the nonprofit sector that includes its characteristics, the legal roots of nonprofit governance, 
and the evolving nature of board expectations. The findings presented in chapter three suggest that nonprofit leaders believe they have enough knowledge to govern, but in reality, may not have correct knowledge of what their fiduciary duties entail. When tested for their actual knowledge of legal responsibilities, only $41 \%$ of the board members and $70 \%$ of the executives received a passing score.

Chapter four focuses on sources nonprofit leader access to learn about their fiduciary responsibilities as a means to satisfy the legal accountability how. The chapter explores the importance of isomorphic pressures as an explanation as to why nonprofit leaders learn about their fiduciary responsibilities. The idea of best practices is presented along with the study results which point to nonprofit leaders' use of informal means, such as relying on their professional and personal networks and other board members to learn about their responsibilities, more so than formalized best practices such as board manuals and orientations.

Chapter five focuses on the frequency with which nonprofit leaders apply their fiduciary knowledge in the performance of their governance duties as a means to satisfy legal accountability for whom. The chapter focuses on competencies, the ability to perform an activity based on knowledge. Chapter five focuses on performance of fiduciary duties to satisfy legal accountability with some discussion about ownership and role ambiguity. The results of this chapter indicate that although nonprofit leaders respond that they are engaged in their governance duties, their performance is based on lack of knowledge of what their actual fiduciary responsibilities are.

Chapter six summarizes the results of each chapter by drawing out the critical issues and gaps in nonprofit governance that this study reveals. With a discussion about 
how to bridge the divide between research and practice, chapter six highlights the need for the two to work in tandem. The chapter also acknowledges the governance challenges and opportunities that many nonprofit leaders face. By offering specific ideas and pathways for how this research can be applied and studied further in both academic and practitioner environments, the study concludes with additional research questions yet to be answered. 


\section{CHAPTER 2: BACKGROUND, RESEARCH DESIGN AND METHODS}

The United States is fortunate to have a vibrant nonprofit sector, from coast to coast, meeting a variety of societal needs. From small grassroots community gardens to world-famous art institutions, nonprofit organizations intersect with every walk of life at every stage of life. Nonprofits are also a financial force for the country. As of 2015, it is estimated that nonprofits contributed $\$ 1.74$ trillion in revenues to the U.S. economy accounting for 5.4 percent of the domestic product (National Center for Charitable Statistics, 2018). Given that the U.S. nonprofit sector plays an important role in the economy, nonprofits are faced with increased demands for accountability as they are relied upon to provide goods and services that benefit society.

For nonprofit organizations, accountability demands come from various stakeholders including funders who want assurances that donations go directly to the mission, clients who want safe, reliable services, and governments who expect nonprofits to use organizational resources to fulfill a charitable purpose. Given the many facets of accountability, this study defines accountability in terms of the legal standards that nonprofit boards and executives are responsible to fulfill in their oversight and management role as nonprofit leaders. As such, this study is focused on the fiduciary duties of care, loyalty, and obedience set forth by state and federal legislation and expectations.

Nonprofit organizations are governed by a board of directors, whose primary function is to make decisions about resources (financial, physical, human, and intellectual) so that the organization can fulfill its mission. Boards are either beloved or 
belittled. They are the first ones to receive praise for a job well done and the first ones to blame when something goes awry.

What makes nonprofit board service unique is its voluntary nature. An individual agrees to serve in a position that entails a great deal of legal responsibility regardless of their qualifications. Some board members bring a great deal of knowledge about their role, while others may not fully understand what a board member does. The lack of skill combined with a lack of standardized process to ensure that board members are properly trained is a recipe for disaster. In a study that explored the socialization of nonprofit board members, Castor and Jiter (2013) found that while some board members received trainings related to their board service others were completely unaware and woefully prepared for board service.

Boards of directors work in partnership with the chief executive, who makes decisions about the day-to-day management of the organization. The executive is bound by many of the same legal requirements as boards are, because they are in a position of influence and have access to resources. Because of the management function that nonprofit executives have, accredited degree and certification programs have been developed over the past few decades to provide nonprofit executives with more formalized training in management and leadership. These professionalized skills can support greater demands for services, navigate increased competition for funding, and fulfill the public's trust (Young, 1999). Although these programs are an important step, they still do not provide a standardized system with which to hold nonprofit leaders accountable for knowing their legal responsibilities. 


\section{Nonprofits in the News}

When news of a nonprofit scandal breaks, accountability is typically called into question. Examples of well-known nonprofit organizations exposed because of financial misappropriations and oversight failures such as the United Way, Wounded Warriors Project, and Central Asia Institute suggest that nonprofit leaders, board members, and executive staff may be asleep at the wheel. Each case highlights how the lack of oversight and accountability, specifically by those who were entrusted with organization resources, resulted in negative immediate and long-term impacts.

\section{The United Way}

The United Way provides a lesson in nonprofit accountability and inadequate board oversight when details of excessive executive compensation and benefits went public (Kearns, 1996). Prompted by an article in the Washington Post in 1992, the Federal Bureau of Investigations and the Internal Revenue Service began an investigation of the United Way of America's national office (Shapiro, 2011). The article reported that William Aramony, the chief executive officer, was receiving $\$ 460,000$ in benefits and compensation, which at the time seemed excessive (Shapiro, 2011). After the investigation that culminated in a federal trial, Aramony was convicted on 23 counts of felony charges that included fraud, conspiracy, and filing false tax returns. He was sentenced to seven years in a federal prison (Shapiro, 2011).

The investigation revealed that Aramony, the United Way's chief executive officer of nearly 20 years, was spending lavishly on entertainment, travel, and women throughout his tenure. But, where was the board? According to Shapiro (2011) the board gave Aramony a unanimous vote of confidence a few weeks before Aramony left the 
United Way amidst the allegations. However, during Aramony's trial no witnesses from the United Way were called either by the defense or the prosecution (Shapiro, 2011). The board's absence at the trial may have been an indication of their absence in the boardroom or their desire to not be associated with the scandal.

\section{Wounded Warriors Project}

Another example of a lack of governance and oversight can be found in the case of the Wounded Warriors Project (WWP). What started off as a small program providing essential hygiene and personal items to recently returned wounded United States military veterans, blossomed into an organization with more than $\$ 20$ million in revenues in less than a decade's time (Phillips, 2016). Outwardly, WWP was considered the premiere veteran's organizations in the United States garnering the support of celebrities, politicians, and well known personalities. However, an internal perspective tells a different story with reports of employees being fired or leaving under suspicious circumstances, a toxic organizational culture, and an overbearing chief executive with a “business-like" mindset that focused solely on raising money (Phillips, 2016).

In 2016, CBS News reported that WWP's spending on programs and services was much less than similar veterans organizations (Reid \& Janisch, 2016). The report alleged that rather than spending on its mission, WWP was spending on first class travel and extravagant conference experiences for its employees (Reid \& Janisch, 2016). Coupled with reports of excessive executive compensation, a congressional investigation commissioned by U.S. Senator Chuck Grassley, Chair of the Senate Finance and Judiciary Committee, was tasked with looking into WWP's spending (Hegeseth, 2016). The report found inaccurate reporting, misuse of donor funds, and a lack of appropriate 
management policies and procedures. Although the committee found executive compensation to be reasonable, it did highlight the excessive use of donor funds on employee travel (Grassley, 2017).

\section{Central Asia Institute}

Finally, the case of Central Asia Institute (CAI) tells a similar story of an executive left to his own and a lack of board oversight. CAI grew out of founder Greg Mortensen's desire to help children receive education in remote areas of Pakistan. What began in 1996 as a personal mission to build a few schools, transformed into an internationally acclaimed organization generating more than $\$ 72$ million in donations and revenues by 2011 (Gose, 2012). As the founder, executive director, and a board member of CAI, Mortensen won international fame as the author of Three Cups of Tea and Stones Into Schools, both New York Times bestsellers, and was a recipient of $\$ 100,000$ Nobel Prize winnings from U.S. President Barack Obama (Bullock, 2012; Sieff, 2014). While CAI was basking in the glory of public fame and success, under the surface the organization was falling apart. Mortensen's lack of skills to be an effective executive was compounded by a handful of board members who provided little to no oversight.

A 60 Minutes news segment (Volz, 2012) opened a Pandora's Box when it reported that Mortensen misrepresented facts in his books, prompting an investigation into CAI by the State of Montana Attorney General's office (where CAI was headquartered). The investigation was intended to "determine whether Mortenson and the leadership of his organization had violated the law governing nonprofit corporations" and "centered on whether CAI's officers and directors satisfied their legal duties" (Bullock, 2012, p. 2). What the report revealed was that "the board of directors failed to fulfill 
some of its important responsibilities in governing the nonprofit charity and that "Mortenson failed to fulfill his responsibilities as executive director and as a member of the board" (Bullock, 2012, p. 2). These responsibilities centered around excessive compensation for book sales, travel and personal expenses, and a lack of oversight around internal policies and procedures including conflict of interest, contracts, and reimbursements. Ultimately, Mortensen was ordered to pay CAI \$1 million dollars and was barred from any future financial oversight, either as a board member or executive, and requirements for CAI to institute internal controls and management policies and procedures to prevent future mismanagement were established.

\section{The Need for Accountability}

What the United Way, Wounded Warrior Project, and Central Asia Institute cases have in common is a lack of oversight at both the board and executive levels. Nonprofit leaders are legally required to ensure that all resources (human, financial, physical, and intellectual) are used to fulfill the mission. However, as seen in these cases, the board was negligent in their oversight of the executive, the executives failed in their management responsibility, and little evidence of suitable internal policies and procedures to ensure that resources were used appropriately. What these cases provide is a spotlight not only on mismanagement, but point to a larger issue: Did these boards know, and understand, what they were legally responsible for and if so, would they have acted differently?

These cases highlight the need for greater accountability and a standardized process to ensure that board members and executives are held accountable to understand their legal responsibilities. The following explains the legal environment that nonprofits must operate within including the requirements for which nonprofit leaders are held 
accountable, specifically the fiduciary duties of care, loyalty, and obedience. Following the discussion related to legal responsibilities, the framework for the study is presented which focuses on the three facets of accountability - Accountability for What; Accountability How; and Accountability to Whom. Following the discussion on accountability, the rationale for the research design of the study is discussed and concludes with the methods used.

\section{Nonprofit Structure and Legal Requirements for Governance}

Nonprofit organizations are governed by volunteers who serve as board members, along with senior executive staff, who are typically paid employees. For the purposes of this study, the term governance will be used as Cornforth (2012) describes it as the "systems and processes concerned with ensuring the overall direction, control, and accountability of the organization" (p. 1121). It is the governance of nonprofit organizations that nonprofit leaders (board members and executives) are legally responsible for carrying out as regulated by state and federal authorities. The following provides background about the nonprofit structure that is based on state and federal legislation, tax codes, and requirements for tax exempt organizations.

\section{Nonprofit Structure}

In all fifty states in the United States, corporations are considered private; meaning they are separate from government. The same is true for nonprofit organizations as they are private corporate entities distinct from government ${ }^{1}$. Although most nonprofits are considered private corporations, what separates a private nonprofit from a private for-profit corporation is how the profits are distributed and tax exempt status. The

\footnotetext{
${ }^{11}$ In some cases nonprofits are public corporate entities if they are established by governmental legislation,
} 
tax exempt status allows for tax free revenues as well as the ability to receive charitable donations. According to Hansmann (1980) the non-distribution constraint prohibits resources from benefitting an individual or select group of individuals. Therefore, the non-distribution constraint suggests that rather than generating wealth for a few, nonprofits are designed to benefit the public by meeting a broader societal need.

The term nonprofit is relatively modern in that it gained traction after World War II (Dobkin Hall, 2006). Referenced by lawyers, economists, and legislators it is used mainly for tax law purposes in order to classify corporate entities that are not taxed. Although the term nonprofit organization is a widely accepted label for charitable organizations according to Overton and Frey (2002), the term nonprofit corporation is an "artificial creation of a government" (p. xviii) that in reality is used to describe what it is not rather than what it is. The technical, legal term that the Internal Revenue Service (IRS) uses to identify a private corporate entity that is excluded from paying taxes on its revenues is a tax-exempt organization.

Tax-exempt status is only obtained if the private corporate entity serves a charitable, scientific, educational, or religious purpose as outlined by the IRS, thereby aligning with the non-distribution constraint (Fishman, Schwarz, \& Mayer, 2015). As such, tax exemption allows public support (i.e. charitable donations and tax free revenue) to support a public need. The term charitable refers to any activity that "uplifts mankind" or that "aims to improve the world" (p. 3), while the term charity refers to the entity carrying out the charitable work (Freemont-Smith, 2004). Although nonprofit organizations are technically charitable organizations, the term nonprofit has become the widely accepted term used to refer to a charitable organization. Other terms used when 
discussing nonprofit organizations include charity, tax exempt organization, and exempt organization. To summarize, nonprofit organizations are private entities that are exempt from paying taxes on revenues in order to provide a charitable service to society. For this study, the terms nonprofit organization, nonprofit, and tax-exempt organization are used interchangeably.

\section{Legal Standards and Regulations}

Over the years, several federal and state legislative acts have been adopted to outline governing expectations for nonprofit organizations. The Model Nonprofit Corporation Act (MNCA) is a comprehensive set of statutes developed by the American Bar Association in 1964 that outlines the general responsibilities of nonprofit boards of directors and trustees (Fishman, Schwarz \& Mayer, 2015). Based on the Model Corporation Act of 1952, the MNCA provides guidance for a wide variety of nonprofit governance functions including filing documents, nominating board members, financial provisions, voting procedures, indemnification, and dissolution. It has become a widely adopted standard that many states use in their own statutes and laws. Yet even with this guidance, many high profile examples of both private and nonprofit mismanagement have resulted in the breakdown of public trust and more demands for transparency, accountability, and performance. In response, federal and state legislators have enacted additional legislation to strengthen the accountability and transparency demands.

In reaction to the for-profit scandals of the 1990's such as Enron, Tyco, and WorldCom, the U.S. government adopted the Sarbanes-Oxley Act (SOX) in 2002 that established new requirements for financial transparency and accountability (Renz, 2010, p. 60). Seeing this as the "writing on the wall", the nonprofit community came together to 
develop their own set of standards. The first to formalize a set of standards was California. Signed into legislation in 2004 the California Nonprofit Integrity Act was legislation designed to ensure financial transparency and accountability amongst nonprofits (Fishman, Schwarz \& Mayer, 2015).

At the federal level, the U.S. Congress responded to the mismanagement of Hurricane Katrina relief efforts in 2007 by its federally chartered charitable agency, the American Red Cross (Hopkins, 2009). After a thorough review of the agency, Congress made several recommendations in order to strengthen governance that focused on board operations, roles, and responsibilities that many nonprofits use today as best practices (Hopkins, 2009). More recently, New York enacted the Nonprofit Revitalization act in 2013 to "reduce unnecessary and expensive regulatory burdens on nonprofits and to strengthen nonprofit governance and accountability" (Kelch, 2014, p. 1). What these regulations have in common is the expectation that nonprofit governing boards and management be held accountable to fulfill their fiduciary duties or legal responsibilities.

\section{Fiduciary Duties of Loyalty, Care, and Obedience}

The legal requirements that nonprofit leaders (board members and executives) are held accountable for are referred to as their fiduciary duties. Fiduciary is based on the Latin term fiducia, which means trust and describes persons who are "obliged to act unselfishly and to give other persons or institutions the advantage of their knowledge and skill” (Fishman, Schwartz \& Mayer, 2015, p. 120). It is interesting to note that the majority of nonprofit practitioners do not use the formal term fiduciary, but rather refer to their oversight role as governance. 
The basis for all nonprofit legal responsibilities lies in the fiduciary duties of care, loyalty, and obedience. Combined, these duties focus on the use of resources and outline what nonprofit leaders are responsible for in their oversight role as presented in Table 2.1. The duties of care, loyalty, and obedience work together, however, individually they define specific aspects of governance. For example, the duty of care requires that nonprofit leaders be engaged in their role and act in good faith when making decisions. The duty of loyalty focuses on conflict of interest and requires nonprofit leaders to act in a manner that puts the organization's interests above their own. Finally, the duty of obedience focuses on compliance and requires nonprofit leaders to fulfill all state and federal laws that govern the organization.

Table 2.1

Nonprofit Leader Fiduciary Duty Responsibilities

\begin{tabular}{|l|l|l|}
\hline $\begin{array}{l}\text { Duty of Care: Engagement, } \\
\text { Attention, Informed Process of } \\
\text { Decision-Making }\end{array}$ & $\begin{array}{l}\text { Duty of Loyalty: Procedural } \\
\text { Aspects of Transactions and } \\
\text { Self Interest }\end{array}$ & $\begin{array}{l}\text { Duty of obedience: Legal } \\
\text { Compliance }\end{array}$ \\
\hline $\begin{array}{l}\text { - Attends board meetings } \\
\text { Reviews information in } \\
\text { advance in preparation for } \\
\text { board meetings and to } \\
\text { inform voting }\end{array}$ & $\begin{array}{l}\text { Discloses conflict of } \\
\text { interests and potential } \\
\text { self-benefit }\end{array}$ & $\begin{array}{l}\text { Ensures compliance with } \\
\text { state and federal } \\
\text { requirements }\end{array}$ \\
$\begin{array}{l}\text { Exercises independent } \\
\text { judgment }\end{array}$ & - $\begin{array}{l}\text { Avoids organization } \\
\text { resources for personal use } \\
\text { Regularly reviews } \\
\text { finances, policies, and } \\
\text { executive performance }\end{array}$ & $\begin{array}{l}\text { Reviews and } \\
\text { understands corporate } \\
\text { governance documents } \\
\text { including bylaws }\end{array}$ \\
\hline
\end{tabular}

Source. Hopkins, 2008

\section{Nonprofit Leaders: Board Members and Executives}

Using a legal perspective, nonprofit leaders are the individuals who are held legally responsible for how organizational resources are used. These leaders include board members and executives who make decisions about how best to use organizational resources in order to fulfill a tax exempt mission. Together, they work to accomplish 
goals and fulfill the mission of the organization in complementary ways; board members meet broader governance needs by ensuring that the organization has the appropriate resources in place that executives then use in the management of the day-to-day operations.

Board members. Board members are volunteers, although there are some organizations that compensate board members, and come from all walks of life. Some board members are recruited because they have a specialized skill such as finance, legal, or marketing while others are recruited because of their connections in the community, which could bring in additional donors. An ideal board member is one who believes in the mission of the organization and is willing to give of their time, talent, and treasure.

Boards are made up of individuals who fill executive positions of president, vice president, treasurer, secretary, and as general board members. As of a national survey of more than 4,000 nonprofit organizations across the United States in 2017, the average board size was 15 members (BoardSource, 2017). In California, private corporations must have at least one board member. However, tax-exempt organizations must fill the president, secretary, and treasurer offices thus requiring nonprofits to have a minimum of three board members.

Boards meet to provide oversight, make decisions about resources, and approve organizational policies and procedures. Renz (2010) sums up the scholarly and practitioner literature related to what board members are responsible for with regards to governance and oversight functions as presented in Table 2.2. However, it is important to note that not all of the recommended functions are tied to the fiduciary duties of care, loyalty, and obedience. For example, although it may be helpful for boards to assess 
board effectiveness, engage with constituents, and lead the organization, technically they are not legally responsible for these activities. However, the literature does tell us that if a board engages in all of these functions by default they will be fulfilling their roles and responsibilities. The duties that are not legal ones have been identified by the researcher and are italicized and presented in Table 2.2.

Table 2.2

Prescribed Board Responsibilities Related to Fiduciary Duties

\begin{tabular}{ll} 
Prescribed Board Responsibility & Addressed in Fiduciary Duties \\
\hline To lead the organization & No \\
Establish policy & Yes \\
Secure essential resources & Yes \\
Ensure effective resource use & Yes \\
Lead and manage the chief executive & Yes \\
Engage with constituents & No \\
Ensure and enable accountability & Yes \\
Assess board effectiveness & No \\
\hline
\end{tabular}

Note. Prescribed board responsibilities reprinted from Nonprofit Leadership and Management, Renz (2010) p. 131-134.

Embedded within the fiduciary duties is the expectation that boards abide by corporate documents including the articles of incorporation, bylaws, and any formally adopted internal policies and procedures. The articles of incorporation detail how the organization was formed and its purpose. Bylaws are guidelines, as set forth by the organization itself, as to how it will conduct the business of the organization and are not legally binding until the board adopts and/or amends them. Policies and procedures, once formally adopted by the board, detail how decisions about resources are to be made. As with policies and procedures, once formally adopted by the board bylaws become a legal document that nonprofit leaders must abide by. There have been cases where boards have been penalized for not abiding by federal and state laws, bylaws, policies, and procedures such as failure to pay taxes, violation of employment laws, conflict of interest, personal 
benefit, and lack of oversight in general (Fishman, Schwartz \& Mayer, 2015; Herman, 2006; Kearns, 1996).

According to Renz (2010), individual board member conduct affects the board as a whole, because board members are held liable for their individual actions and corporately the board is held liable for its actions as an entity. For example, if an individual board member has knowledge of a potential conflict of interest regarding a contract for services, the board member must inform the board of the conflict in order to fulfill their duty of loyalty. If they do not divulge the conflict and the contract is approved, they would be held liable for breaching their duty of loyalty. Duty of loyalty requires that individuals put the best interests of the organization above their own. Conversely, if the board moves forward with the said contract and an individual board member financially benefits, thus the conflict of interest, the board would be held liable for a breach in their duty of care. The duty of care requires informed decision making and if the board asked about finer details of the contract they most likely would have discovered the conflict of interest.

Executives. The most senior executive is usually referred to as the executive director (ED) or chief operating officer (CEO). As the most senior executive, they are responsible for managing and implementing the day-to-day operations. Typically, executives are hired by the board to implement board approved policies and procedures, to provide staff and operational oversight, and to serve as the liaison between the board and the organization. The executive is relied upon by the board to ensure that the organization is using its resources to fulfill its mission. Although board members and the executive fulfill distinct roles, many of their functions and duties overlap. For example, 
board members review organizational reports such as financial statements, programrelated activities, donor relations, and public awareness efforts that are prepared by in advance by the executive. Given this overlap, they are both legally held accountable for their actions because they are both involved in acquiring, managing, and allocating organizational resources.

Although executives are held to the same legal standards as board members, many executives are hired because of their professional experience in management, operations and fundraising, not because of their knowledge of fiduciary duties. During my nearly 20 years as a nonprofit practitioner and consultant, I have yet to attend an interview (either as the candidate or as the employer or search consultant) where the legal duties are even discussed. Furthermore, many boards do not fulfill their fiduciary duty of care by regularly evaluating the performance of the executive. BoardSource (2017) reported that the executives themselves graded the evaluation process with a B- (p. 28).

The traditional hiring process is that candidates are expected to have some prior knowledge and experience as a condition for being hired (Miller \& Jablin, 1991) and the need for experience increases as the level of specialization increases. For example, a cashier job has vastly different requirements than a civil or electrical engineer. Yet, for many nonprofits, leadership and oversight responsibilities are bestowed upon executives without any confirmation that the appropriate knowledge is in place. What is in the best interest of the organization (i.e. duty of loyalty) is that the board hires an executive who has both professional skills and an explicit understanding of the legal responsibilities related to governing and managing a nonprofit. 


\section{Accountability}

\section{What is Accountability?}

Accountability has become a frequent topic in all aspects of society. From political scandals, to corporate malfeasance, to national and international tragedies, people want to know who to hold accountable. Given its prevalence in the world around us, the scholarly literature is still searching for a clear definition of accountability since it means different things to different people. In terms of nonprofits, some scholars focus on the economic, political, or legal aspects of accountability while others point to the need to include the public and other stakeholders such as clients and donors (Ebrahim, 2010; Holland \& Ritvo, 2008; Kearns, 1996; Renz, 2010; Smith, 2014). Koppell (2005) offers that where someone is situated, such as the CEO, line staff, or customer, impacts how accountability is defined for that particular context. He furthers that accountability should be based on the expectations of the relationship itself, such as between the executive and the board for example (Koppell, 2005). For the public, accountability focuses on the expectations of "organizational performance, responsiveness, and even morality" (Kearns, 1996, p. 9). However, Koppell (2005) cautions that "layering every imagined meaning of accountability into a single definition would render the concept meaningless" (p. 95).

The variety of perspectives and stakeholders is important to highlight when trying to understand accountability for nonprofits. Given that there are nearly two million nonprofits in the United States (National Center for Charitable Statistics, 2018) different stakeholders rely on the wide variety of programs and services in different ways for different reasons. For example, someone without medical insurance depends on a 
community nonprofit clinic for critical healthcare while a wealthy art patron relies on a nonprofit museum to view their favorite masterpieces. Because of this contextual nature of accountability, Slim (2002) offers that, "a key part of the process of tailoring the right accountability mechanism to the right stakeholders is recognition of context" (p. 11). An element of accountability involves answering to a "higher authority" (Kearns, 1996, p. 7). This type of accountability can be viewed as compliance, which is a reactive response to requirements or obligations (Ebrahim, 2010; Holland \& Ritvo, 2008; Kearns, 1996). If legal enforcement entities such as the IRS and a state's charity oversight agency such as an Attorney General are called in to investigate potential breaches of public trust and accountability, they refer to the fiduciary duties as the basis for their investigation. Therefore, the duties provide a framework for the investigation that focuses on how board members and executives made decisions and if those decisions were made in a manner that upholds the fiduciary duties. What this means for nonprofits is that legally, they must respond and answer to the regulators who hold them accountable to convey their effectiveness in their roles and responsibilities. So, the fiduciary duties become the legal standard for what the organization is held accountable.

Accountability can also be described as proactively responding to the needs of its constituents (Ebrahim, 2010) as well as how it performs or fulfills its legal responsibilities. The duties of care, loyalty, and obedience based in U.S. case law are the "legal standards by which all actions taken by directors are judged" (Hopkins, 2009, p. 13). Many instances where the fiduciary standards have been applied to cases of nonprofit mismanagement and negligence are examples of how nonprofit leaders are judged (see chapter three). What this means for nonprofits is that they must be both 
responsive in meeting the demands of the public and responsible for following the expectations (i.e. fiduciary duties). Therefore, in looking at legal accountability through a fiduciary, legal lens, nonprofits are required to take responsibility for using of organizational resources in a manner that fulfill the mission.

Because accountability has such a wide range of contexts, meanings, and mechanisms, knowledge of the basic legal fiduciary duties of care, loyalty, and obedience is critical in order to meet legal accountability demands. For the purposes of this study, accountability is explored through the legal accountability lens: the federal and state expectations for nonprofit leader oversight which is the standard by which all nonprofit leaders are evaluated against. As such, nonprofit leaders who understand their basic legal fiduciary duties can perform their fiduciary duties and consequently satisfy legal accountability demands as illustrated in Figure 2.1.

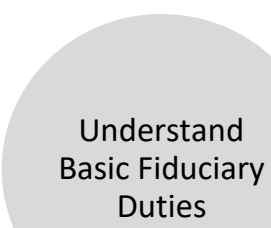

Duties

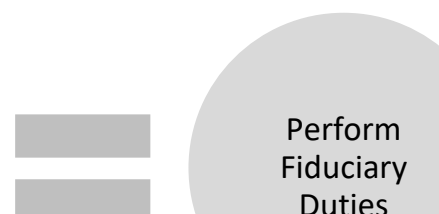

Duties

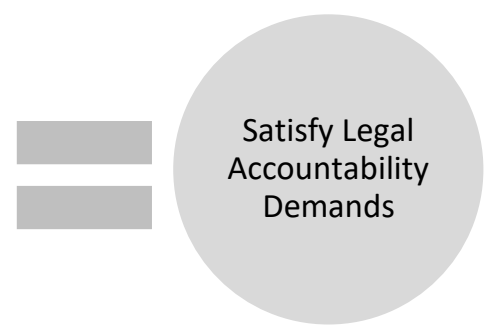

Figure 2.1. Legal Accountability Process

\section{Research Design}

\section{Accountability Framework}

The study focuses on nonprofit leader knowledge, source of knowledge, and application of knowledge related to the fiduciary duties of care, loyalty, and obedience as a means to fulfill legal accountability. In looking at the overall design of the study, a framework used by several scholars (Ebrahim, 2010; Kearns, 1996; Slim, 2002) is 
applied that categorizes accountability into three areas: Accountability for what;

Accountability how; and; Accountability to whom as illustrated in Figure 2.2. The purpose for using this framework is to operationalize how accountability is expressed as legal accountability using the framework of the fiduciary duties of care, loyalty, and obedience.

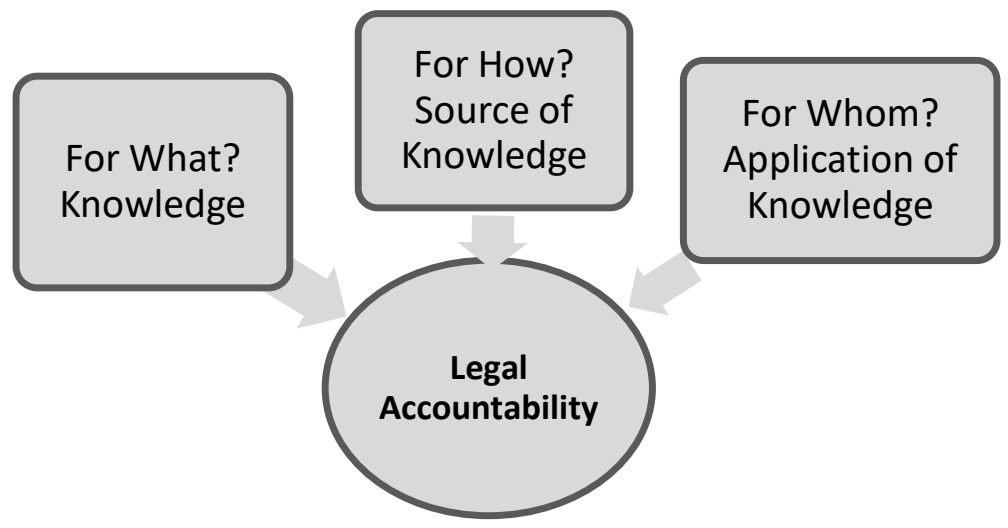

Figure 2.2. Framework for Legal Accountability adapted by Ebrahim (2010) The many faces of nonprofit accountability.

In terms of legal accountability, the fiduciary duties provide guidance for nonprofit leaders to understand what they are legally responsible for in fulfilling their governance roles. These duties also provide a standardized measure to assess nonprofit governance performance and effectiveness. If nonprofit leaders understand their legal duties, roles, and responsibilities, they will make more informed decisions that fulfill the tax-exempt mission, leading to better performance and effectiveness.

Without much research to build that includes data about individual nonprofit leader knowledge of their fiduciary duties, this study fills a gap in the literature about what board members and executives know about their legal responsibilities (accountability for what), the sources they access to learn about their responsibilities (accountability how), and how they apply their fiduciary knowledge in the performance 
of their governance activities (accountability for whom). The following section explains how the study is embedded in each area of the accountability framework and how the key terms are defined including knowledge, source of knowledge, and application of knowledge. The rationale is important to lay out up front as it applies to the following three chapters that correspond to each of the accountability categories and research constructs as presented in Figure 2.2.

\section{What is Knowledge?}

The study primarily centers on knowledge that has its roots in epistemology: the way in which we know or learn. Epistemology considers many complex and dynamic concepts of knowledge that can be defined cognitively, practically, theoretically, socially, and even spiritually (Greco \& Sosa, 1999). For example, a practical definition of knowledge would be useful in order to "know" what something may cost in financial terms while a socially oriented definition focuses more on how people interpret their own experiences that result in "knowledge" (Zagzebeski, 1996).

This study is utilizing a framework for knowledge originally intended for medicine. Although it is based in medicine, it provides utility for the study because medical professionals are relied to uphold their Hippocratic Oath, an allegiance to do no harm. Nonprofit leaders are also relied upon to do no harm in that they are entrusted with public resources for public good. In an effort to measure how cognitive recognition translates into behavior, Miller (1990) developed a model intended for clinical assessment of medical professionals as illustrated in Figure 2.3. As a means to better understand how well medical professionals take what they have learned and apply it in a clinical setting, Miller (1990) offers that knowing something does not necessarily mean 
that someone is able to carry out that knowledge. He identifies a sequence of how cognitive knowledge turns into action, which is of particular importance for nonprofit leaders because they make decisions about organizational resources (action) based on knowledge.

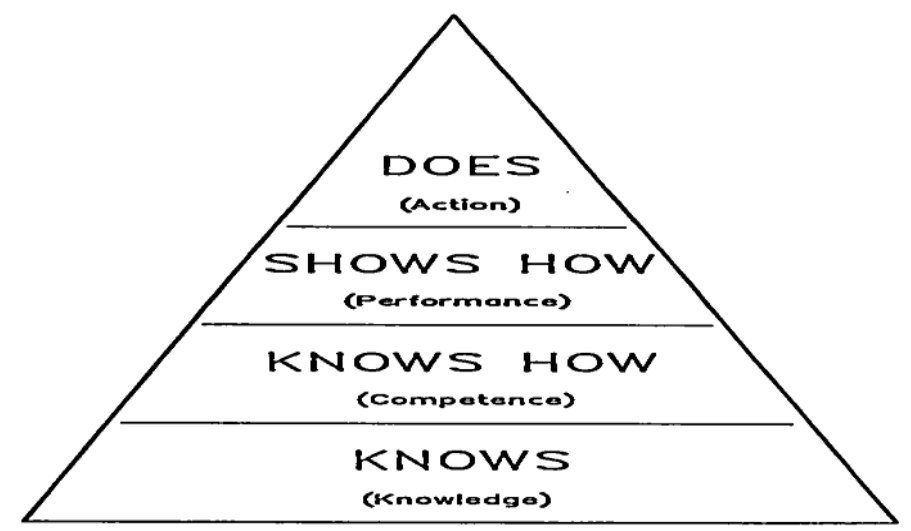

Figure 2.3. Miller's Framework for Clinical Assessment. Reprinted from The assessment of clinical skills/competence/performance, Academic Medicine (1990).

What Miller's (1990) model provides for the study is a framework that parses out the different levels of knowledge. As illustrated in Figure 2.3, the first level is the "knows" level. Knowing something means that you can recall and articulate specific elements. For example, if someone knows math, they are able to recall and articulate mathematical equations, formulas, and so on. The first level of knowing provides the foundation for the next level, "knows how."

When someone knows how to do something, they activate knowledge into competence. For example, the mathematician conveys that they know math by articulating specific elements and they demonstrate competence by doing the calculations related to the equations and formulas. Knowing how supports the next level, which is "shows how." 
The "shows how" level expresses that performance is a combination of knowledge and competence. For example, the mathematician would show how and demonstrate performance by accurately solving said equations and formulas. The shows level supports the final level, which is "does."

The final level is the "does" level that expresses action. Miller (1990) describes action in terms of performing knowledge outside of traditional academic settings, in other words, with actual patients. So, in looking at the mathematician example, the doing level is expressed when formulas and equations are accurately calculated are used in a way that translate into a real-world situation such as engineering.

\section{Study Framework}

As illustrated in Figure 2.4 each level of knowledge creation can be applied to the constructs in the study: Knowledge, Source of Knowledge, and Application of Knowledge. The first level, the "knows" level, focuses on the first strand of research, knowledge of fiduciary duties and corresponds to the facet of accountability for what. In this level, the respondents are asked how familiar they are of each of the fiduciary duties. This level includes self reported knowledge and actual knowledge described more in the following methodology section. The results of nonprofit leader knowledge of their fiduciary duties are presented in chapter three.

The second level, the "knows how" level, focuses on the second strand of research, the types of sources nonprofit leaders access in order to learn about their responsibilities and corresponds to second facet of accountability, for how. In this level, respondents are asked to select from a series of internal and external best practices to better understand how they learn about their fiduciary responsibilities. The results of the 
sources that nonprofit leaders access when learning about their responsibilities are presented in chapter four.

The last two levels, "shows how" and "action," overlap in that they focus on action and performance. For this study, these two levels are combined by focusing on the third strand of research, how nonprofit leaders apply their governance knowledge in the performance of their governance duties that corresponds with the third facet of accountability, for whom. The results of nonprofit leader application of their fiduciary duties are presented in chapter five.

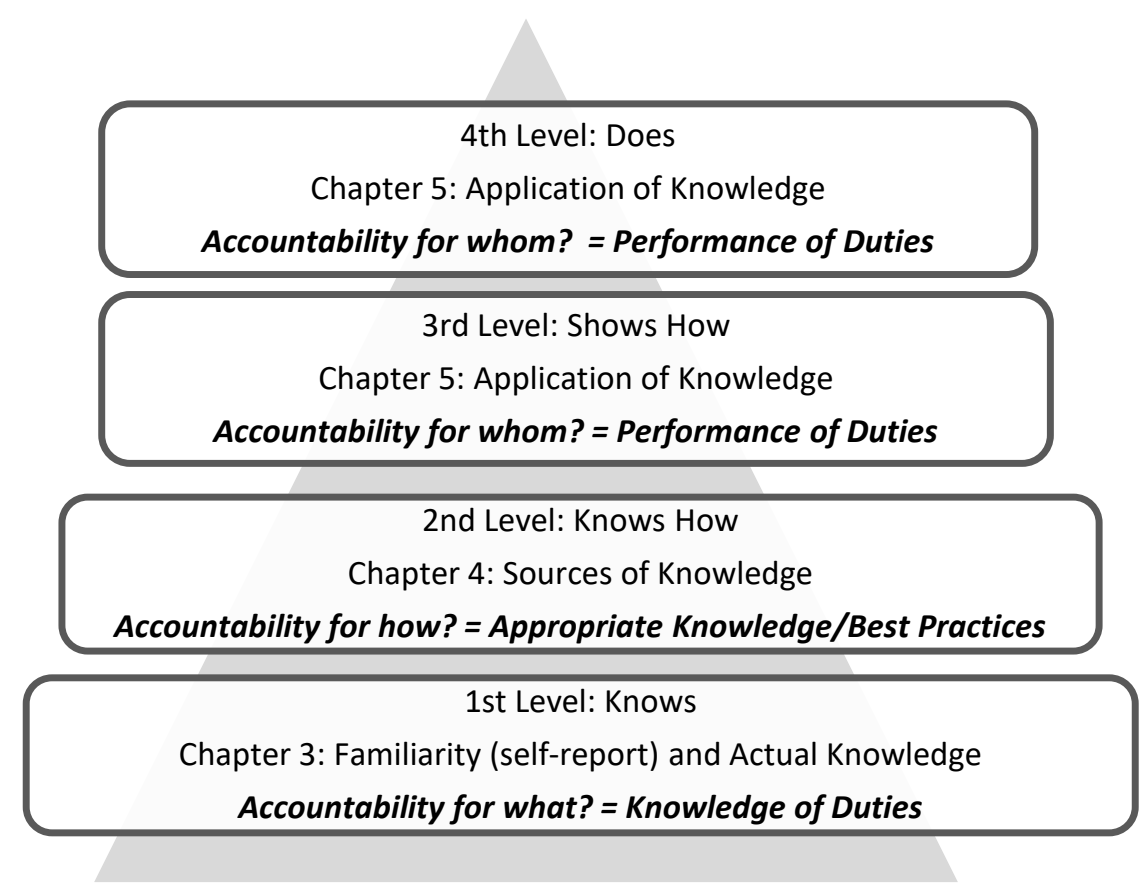

Figure 2.4. Knowledge and Study Design.

\section{Accountability for What?}

What follows is an explanation of how the accountability framework is applied to the constructs of knowledge, sources of knowledge, and application of knowledge with regards to this study. Starting with the first facet of the accountability framework used in this study, the following is a discussion about what nonprofits are accountable for. Given 
that nonprofits are held accountable by a variety of different stakeholders, legal accountability is the most straightforward. Nonprofits provide a charitable service to society and their work is subsidized through tax exemption. Because tax exemption is a function of legislation that is enforced and regulated by the IRS, the fiduciary duties provide tangible guidelines and expectations for oversight and governance. For example, it would be relatively simple to determine if a nonprofit leader is fulfilling their duty of care by asking how often they attend meetings and if they read the materials in advance of meetings. Therefore, if nonprofit leaders can satisfy the legal accountability expectations, it could provide a basis to determine if they are fulfilling their fiduciary responsibilities.

In an effort to help nonprofit leaders understand what nonprofits are accountable for, Ebrahim (2010) outlines four areas of accountability including, finances, governance, performance, and mission. Financial accountability focuses on reports such as profit and loss statements, cash flows, audits, and IRS 990 tax returns provide concrete information that the public generally understands. For nonprofits to meet financial accountability demands, they are making decisions that rely on sound financial reporting, budgeting, and policies. They also focus on revenues and expenses and try to demonstrate that they use their financial resources to fulfill their mission.

Performance for accountability is about how tools such as logic models and strategic plans support the mission and centers around the idea as Ebrahim stated that, "organizations should be held to account for what they deliver" (as cited in Renz, 2010, p. 106). For nonprofits who meet performance accountability demands, they use organizational processes and tools as a means to identify metrics of success. Nonprofits 
that focus on metrics and outcomes do so because of pressures by funders and other actors to demonstrate performance. However, the idea of performance is riddled with complexity as the literature is still trying to determine what type of specific performance measures for which nonprofits should be accountable.

Accountability for the mission is similar to performance for accountability in that nonprofits are asked to account for what they were created to do: their mission.

Nonprofits who meet mission accountability are constantly looking ahead, surveying the environment for changes that may impact their work. While this kind of behavior seems logical, the downside of focusing on this mission accountability is that it requires continual reflection and monitoring which takes time. Ebrahim (2010) suggests that nonprofits need to internalize the mission and continually monitor performance, but also identifies the need to allow for continual learning and change.

Governance accountability, according to Ebrahim, focuses on "how the organization [boards and executives] raises and spends money, follows donor intent, and whether it is in compliance with the law" (as cited in Renz, 2010, p. 105). This perspective aligns with the expectations of the fiduciary duties. However, the notion of basic oversight has evolved into greater demands of the board as Ebrahim (2010) points out that boards are expected to be accountable for more than just financial oversight, but also for organizational performance. The broader demands of board members go beyond basic resource oversight and include strategic planning, engaging with communities, advocating for the organization, educating about the mission, and providing expertise in their specialized field. However, as much as this sounds appealing, if a nonprofit leader does not have the basic understanding of what they are legally responsible for, any 
decisions made about strategy and direction will be made out of ignorance rather than facts. Accountability for governance, more specifically accountability for legal responsibilities, is a critical element needed to meet accountability demands.

\section{Accountability for What? Knowledge}

Appropriate knowledge of fiduciary responsibilities is how nonprofit leaders can fulfill what they are accountable for and satisfy legal accountability. By focusing on the basic oversight perspective, accountability for what is demonstrated by nonprofit leader knowledge of the fiduciary duties of care and loyalty. Knowledge intersects with the first level of "knows" and is the first construct that assesses what nonprofit leaders believe they know (i.e. self-reported) about their fiduciary responsibilities and what they actually know. Details follow in the methodology section about how knowledge is assessed in the survey instrument.

\section{Accountability How?}

Because nonprofits are accountable to multiple actors for different things Ebrahim (2010) discusses how accountability actually occurs. He focuses on five types of mechanisms for accountability including reports and disclosure statements, evaluations and performance assessments, participation, adaptive learning, and industry selfregulation. Each type of mechanism is identified as a tool or process and as with accountability for what, these tools and processes have both strength and weaknesses (Ebrahim, 2010).

Ebrahim (2010) provides a distinction between tools and processes with regards to how nonprofits meet accountability demands. Tools include those things that can be used repeatedly, over a period of time. He suggests that disclosure statements and reports 
and evaluation and performance assessments are tools used as a means for accountability. Processes, on the other hand, are broader and multi-faceted such as overall participation and adaptive learning that allow nonprofits to focus on the actual work rather than the end product. Examples of participation and adaptive learning include activities that focus on relationships and stakeholders such as a strategic plan or assessments that allow for self reflection and change (Ebrahim, 2010).

Finally, self-regulation is identified as both a process and tool as a mechanism for accountability. Nonprofits that self-regulate as a means to demonstrate accountability follow industry standards and other guidelines that ensure compliance. Ebrahim suggests self-regulation "refers specifically to efforts by nonprofit networks to develop standards or codes of behavior and performance" (as cited in Renz, 2010, p. 110) often referred to as best practices. Best practices are standards or codes that nonprofits use for a variety of nonprofit management functions such as finances, human resources, marketing, fundraising, and programs. They are developed and typically shared through nonprofit networks, associations, academic programs, and by funders as a means to standardize nonprofit behavior. Nonprofits who demonstrate accountability how utilize and access appropriate best practices in order to gain knowledge about their roles and responsibilities.

\section{Accountability How? Source of Knowledge}

In order for nonprofit leaders to satisfy legal accountability how, nonprofit leaders must access appropriate sources to learn about their fiduciary responsibilities. Miller (1990) furthers the idea that in order to measure competence and performance, one must not only measure actual knowledge and how it is used, but also how knowledge is 
acquired. Therefore, the second construct in my study focuses on sources that nonprofit leaders access to learn about their fiduciary responsibilities. These sources, or best practices, are a type of self regulation mechanism that nonprofit leaders use to demonstrate accountability how. The best practices are discussed as internal and external sources that nonprofit leaders access to learn about their responsibilities, thereby intersecting with the second level of "knows how" and competence. Details follow in the methodology section about how sources of knowledge are assessed in the survey instrument.

\section{Accountability to Whom?}

Nonprofits are legally held accountable to know about their legal responsibilities (for what). How they demonstrate their accountability is by utilizing appropriate sources to learn about their fiduciary responsibilities (how). The third leg of the accountability stool is to whom are nonprofits accountable?

As mentioned previously, nonprofits are held accountable by a variety of different actors and stakeholders. From the client who receives services to the funder who financially supports the organization, it is difficult to isolate any one particular "whom" nonprofits are accountable to. Ebrahim and others (Scott, 2000; Ebrahim, 2010; Verschuere, et al 2006) suggest that accountability to whom includes an "upward" and “downward" relationship. Upward accountability refers to external relationships such as with funders, governments and the public. Conversely, internal accountability focuses more on internal relationships such as those receiving services and to some extent larger communities (Ebrahim, 2010). Another perspective was coined by Koppell (2005) as "multiple accountabilities disorder (MAD)" (p. 95). MAD can be seen in the example of 
a nonprofit membership organization. Membership organizations such the Association of Fundraising Professionals (AFP) are held accountable by the national chapter to ensure policies and procedures are followed. Concurrently they are accountable to their local members, chapter board of directors, and state regulators.

The upward and downward perspective, along with MAD, suggests that nonprofit leader performance could be a mechanism that nonprofit leaders meet accountability for whom. As nonprofit leaders apply their fiduciary duty knowledge, they demonstrate accountability to multiple stakeholders via their performance.

\section{Accountability to Whom? Application of Knowledge}

In order for nonprofit leaders to satisfy legal accountability to whom, they must demonstrate competence the results in performance of their fiduciary responsibilities. Holland and Ritvo (2008) argue that competencies are a combination of "skills, knowledge, information, and personal characteristics" that must be practiced in order to be considered useful (p. xvii). They go on to explain that competency is linked to performance and when appropriate competencies are in place, effectiveness follows (Holland \& Ritvo, 2008). This aligns with Miller (1990) who establishes that knowledge

alone is not an adequate measure of performance, but rather suggests that how knowledge is actually carried out is a better indicator. Therefore, the third and final construct in my study focuses on nonprofit leader application of fiduciary knowledge in their governance activities. This performance of duties intersects with the last two stages of "shows how" and "does" and demonstrates accountability to whom. The application construct is assessed by asking about the frequency of application of fiduciary knowledge in oversight activities related to the duties of care, loyalty, and obedience. Details follow in 
the methodology section about how specifically the construct is assessed in the survey instrument.

\section{Assessment and Measurement Rationale}

The following section provides the rationale for several aspects of the study including the assessment tool, the constructs of knowledge (accountability for what), source of knowledge (accountability how), and application of knowledge (accountability for whom) as illustrated in Figure 2.5. Specific methods follow this rationale section.

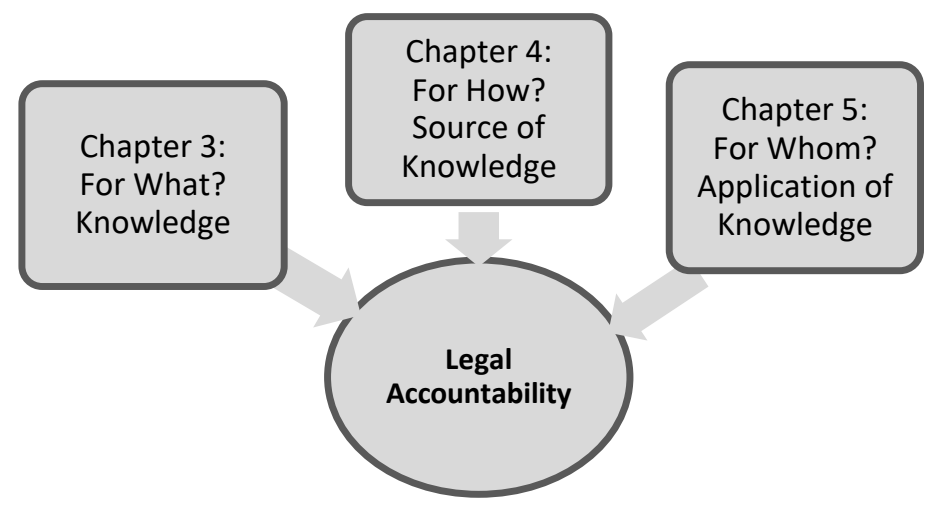

Figure 2.5. Framework for Legal Accountability.

\section{The Instrument}

There are many scholarly and practitioner tools available for nonprofit organizations to assess governance and oversight for accountability purposes. However, there is not currently an assessment that focuses solely on the fiduciary duties of care, loyalty, and obedience. Furthermore, there is not an assessment that asks individual nonprofit leaders specific questions about knowledge of their fiduciary duties. Therefore, in order to fulfill the purpose of this study to establish baseline data from individual nonprofit leaders, an internet-based survey was developed and determined to be the most appropriate assessment tool. 
This rationale to use a survey is based on the need to gather data from a large number of individuals in a neutral, comfortable setting. Additionally, a survey approach provides the opportunity to gather data confidentially. This is important to consider since the questions in the survey itself ask about behavior and knowledge, which can be personal or sensitive in nature (Dillman, Smythe, \& Christian, 2014). With this concern in mind, the respondents were notified that all of their responses would be reported in aggregate and no individual responses will be attributed to any specific individual.

Additional rationale for a survey approach was based on the need to gather data that can be quantified to compare and deductively analyze. Furthermore, nonprofit organizations widely use and administer surveys meaning that nonprofit leaders are accustomed to this type of data collection method. Finally, a survey is a cost-effective method to gather responses from a large geographical area such as the San Diego County region (Dillman, 2000).

\section{Knowledge Rationale}

In keeping with Miller's (1990) framework and to focus on legal accountability, questions developed focused on individual nonprofit leaders' knowledge of the fiduciary duties of care, loyalty, and obedience. Questions related to the specific aspects of the duties are presented in Table 2.3. A full list of questions can be found in the actual survey instrument (see Appendix A). 
Table 2.3

Focus of Questions Related to Knowledge of Duties of Care, Loyalty, and Obedience Construct and Question

Definition

\begin{tabular}{|c|c|}
\hline Duty of Care: & Familiarity/overall understanding \\
\hline Engagement, & Understanding mission \\
\hline Attention, Informed & Understanding responsibilities \\
\hline $\begin{array}{l}\text { Process of Decision- } \\
\text { Making }\end{array}$ & $\begin{array}{l}\text { Legal responsibilities: Regular attendance of board meetings; reviewing } \\
\text { materials; reviewing finances and policies. }\end{array}$ \\
\hline Duty of Loyalty: & Familiarity/overall understanding \\
\hline $\begin{array}{l}\text { Procedural Aspects } \\
\text { of Transactions and } \\
\text { Self Interest }\end{array}$ & $\begin{array}{l}\text { Legal responsibilities: Use independent judgment; disclosing conflict of } \\
\text { interest; no personal benefit of organizational resources }\end{array}$ \\
\hline Duty of Obedience: & Familiarity/overall understanding \\
\hline Legal Compliance & $\begin{array}{l}\text { Legal responsibilities: compliance with federal/state regulations } \\
\text { Bylaw elements: Board positions, terms and voting; nomination and } \\
\text { election process; executive staff responsibilities }\end{array}$ \\
\hline
\end{tabular}

\section{Sources of Knowledge Rationale}

In order to determine what types of sources nonprofit leaders access to learn about their roles and responsibilities and how often, assessment questions were developed that prompt nonprofit leaders to respond to a series of options based on nonprofit industry best practices. Internal sources that were provided by the organization and external sources that are available to the general public were included as illustrated in Table 2.4. A full list of questions can be found in the actual survey instrument (Appendix \#).

Table 2.4

Types of Internal and External Best Practice Sources

\begin{tabular}{ll}
\hline $\begin{array}{l}\text { Internal Best Practices } \\
\text { member orientation }\end{array}$ & External Best Practices \\
$\begin{array}{l}\text { Information conversations with } \\
\text { board members and staff }\end{array}$ & $\begin{array}{l}\text { Magazines, Journals, } \\
\text { Books }\end{array}$ \\
$\begin{array}{l}\text { Educational opportunities } \\
\text { arranged by the organization for } \\
\text { board members }\end{array}$ & $\begin{array}{l}\text { Friends and Family } \\
\text { (network) }\end{array}$ \\
Board Manual & $\begin{array}{l}\text { Certification/Degree } \\
\text { programs }\end{array}$ \\
\hline
\end{tabular}




\section{Application of Knowledge Rationale}

To understand how frequently nonprofit leaders apply their fiduciary knowledge, assessment questions were developed that ask how often nonprofit leaders use their knowledge of the fiduciary duties in their governance role as presented in Table 2.5. As with the knowledge construct, each question focuses on specific aspects of the duties of care, loyalty, and obedience. A full list of questions can be found in the actual survey instrument.

Table 2.5

Questions Related to Frequency of Application of Duty of Care, Loyalty, and Obedience Construct and Questions

Definition

Duty of Care:

Engagement, Attention, Informed Process of DecisionMaking
- Review materials in advance of the board meeting

- Pay attention to the organization's resources (e.g. financial, physical, and human)

- Frequently review the organization's finances and financial policies

- Attend board meetings

- Am aware of the executive's performance

- Participate in the review, discussion, and/or approval of financial policies (e.g. annual budget, audit)

- Exercise independent judgment

Duty of Loyalty: Procedural Aspects of Transactions and Self Interest

Duty of Obedience: Legal Compliance
- Disclose conflicts of interest

- Make decisions that are in the best interest of the organization

- Avoid the use of organizational resources/connections for personal gain

- Maintain confidentiality of sensitive organizational information

- Refer to the mission statement when discussing potential programs and services

- Pay attention to how the organization uses its resources (financial/physical/human) to fulfill its mission

- Board: Understand the Bylaws/Executive: Read the Bylaws

- Refer to the organization's internal policies and procedures when needed

- Consider how new and existing programs support our mission 


\section{Methodology}

The purpose of this study is to establish baseline data about nonprofit leader fiduciary knowledge, source of fiduciary knowledge, and application of fiduciary knowledge. As such, the research methodology was developed by building upon extensive practitioner work and academic scholarship. Although the study is exploratory, attention was given to develop an instrument that could be replicated and validated in other settings to conduct future research. This section outlines the research methods and procedures used for this descriptive, quantitative study, which includes the following sections: sample, survey deployment, constructs and measurement, and data analysis. The assessment tool and forms utilized during the research study can be found in the appendices.

\section{Sample}

The sample for this study was drawn from the population of nonprofit leaders from 11,234 nonprofit, tax-exempt organizations located in San Diego County, CA at the time of the survey deployment in January 2018 (Nonprofit Institute, 2018). Participant eligibility criteria for this study was focused on individuals who were current voting board members or the most senior executive staff of a San Diego County nonprofit, taxexempt organization. The unit of analysis is the individual nonprofit leader. By law, California nonprofit organizations are required to have at least three board positions filled: President, Secretary, and Treasurer (California Attorney General, 2017). Using three as the minimum number of eligible board participants, the total sample would be, at a minimum, 33,702. 
For the number of eligible executives, the possible amount would be one per organization for a total sample of 11,234 . Combined, the sample of eligible participants is 44,936. Of the 218 submitted responses, 189 were deemed viable (less than $1 \%$ response rate) and therefore included in this study.

Of the 218 submitted responses, 114 provided either an organization name or employer identification number. Of the 114 who provided identifying information, eight organizations had more than one response. As such, 18 responses were removed to allow for one response, per organization in order to provide descriptive information about the sample of 96 organizations.

Figure 2.6 illustrates the types of organizations represented by sub-sector. The most were from arts and culture (22\%) and none represented higher education or hospitals. Hospitals were represented only in the philanthropic sub-sector (i.e. foundations), but not as organizations with a health mission.

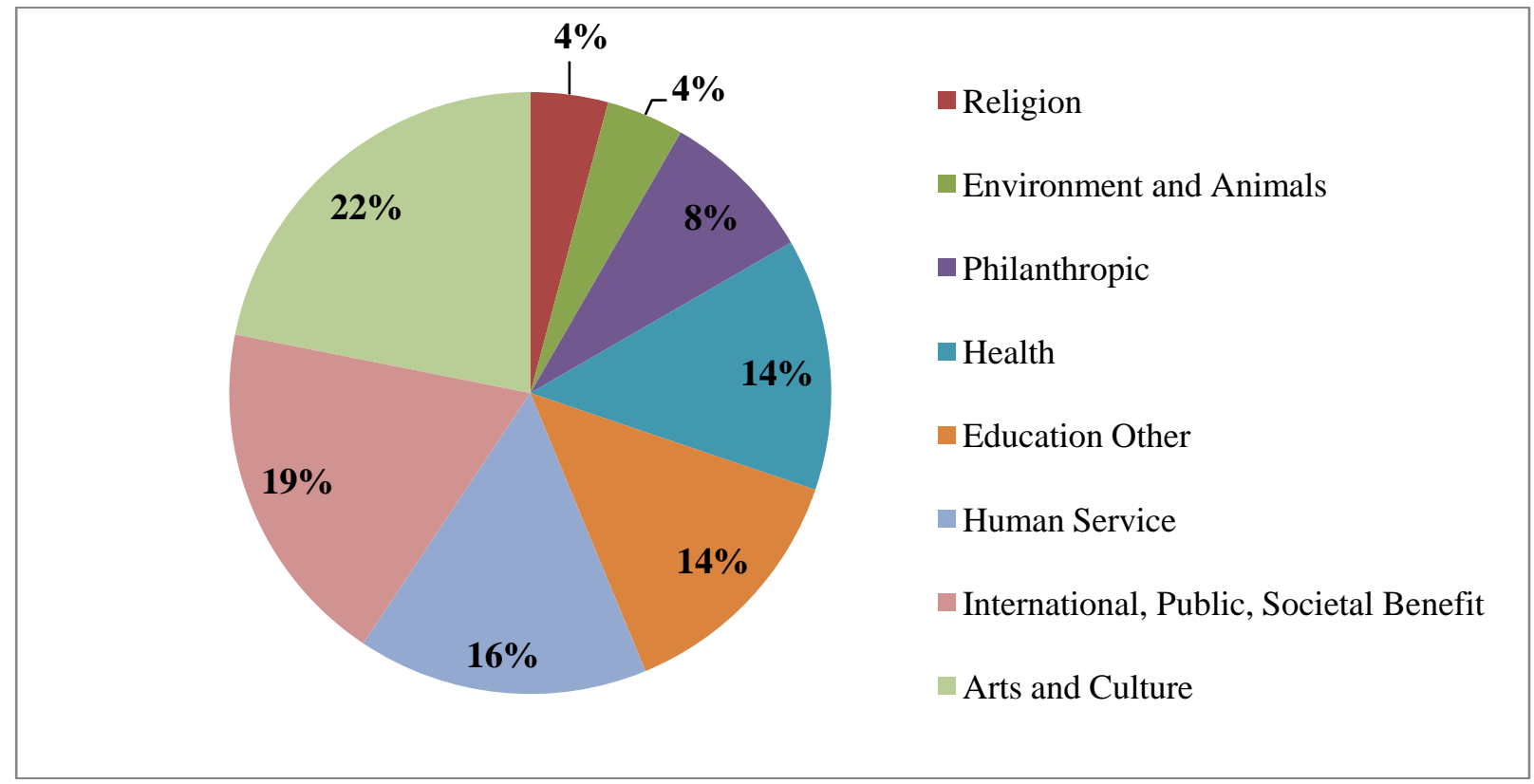

Figure 2.6 Sample percentages by sub-sector for organizations that provided identifying information. 
Table 2.6. presents the averages for revenues and age for those organizations that provided a means to identify them. On average, the organizations with less revenues were those that had International, Public, and Societal Benefit purposes, while larger revenues were represented by Human Service purpose organizations. The youngest organizations were those that were religious with the oldest as Human Service organizations.

Table 2.6

Sample Age and Revenue

\begin{tabular}{lccccc}
\hline & $\begin{array}{c}\text { Avg. Age } \\
\text { (in years) }\end{array}$ & Avg. Revenue & $\begin{array}{c}\text { Low } \\
\text { Revenue }\end{array}$ & $\begin{array}{c}\text { High } \\
\text { Revenue }\end{array}$ & $\begin{array}{c}\text { Median } \\
\text { Revenue }\end{array}$ \\
\hline $\begin{array}{l}\text { Health (n=13) } \\
\text { International, }\end{array}$ & 26 & $\$ 11,293,518$ & $\$ 193,845$ & $\$ 63,316,798$ & $\$ 2,940,908$ \\
$\begin{array}{l}\text { Public, Societal } \\
\text { Benefit (n=18) }\end{array}$ & 21 & $\$ 3,927,012$ & $\$ 84,758$ & $\$ 30,100,526$ & $\$ 1,845,848$ \\
$\begin{array}{l}\text { Human Service } \\
\text { (n=15) }\end{array}$ & 37.1 & $\$ 35,261,337$ & $\$ 229,118$ & $\$ 383,032,435$ & $\$ 5,824,415$ \\
$\begin{array}{l}\text { Education Other } \\
\text { (n=13) }\end{array}$ & 16.8 & $\$ 2,591,179$ & $\$ 174,954$ & $\$ 14,177,868$ & $\$ 808,005$ \\
$\begin{array}{l}\text { Arts and Culture } \\
\text { (n=21) }\end{array}$ & 25.6 & $\$ 1,600,113$ & $\$ 103,293$ & $\$ 16,334,715$ & $\$ 620,816$ \\
$\begin{array}{l}\text { Religion (n=1) } \\
\begin{array}{l}\text { Philanthropic } \\
(\mathrm{n}=8)\end{array}\end{array}$ & 0 & $\$ 0$ & $\$ 0$ & $\$ 0$ & $\$ 0$ \\
$\begin{array}{l}\text { Environment and } \\
\text { Animals (n=4) }\end{array}$ & 24.0 & $\$ 9,548,373$ & $\$ 385,731$ & $\$ 40,823,220$ & $\$ 2,205,383$ \\
\hline
\end{tabular}

Note: Tax information was available for only 1 of the four religion organizations and the one had not filed a tax form yet. Source: Internal Revenue Service Tax Exempt Extract 2017 tax year.

A purposeful, snowball sample approach was utilized by sending the survey out to the researcher's more than fifty personal and professional contacts and networks via email. The contacts represent nonprofit organizations, individuals (nonprofit practitioners and volunteers), academic institutions, and organizations in the San Diego region. All contacts were asked to take the survey, provided they met eligibility criteria, and to forward the survey on to their own professional and personal networks. 


\section{Respondent Demographics}

Because of the length of the survey (98 questions) the researcher was concerned about survey fatigue and as such limited the number of demographic questions to the respondent's role, the number of boards respondents served in the last 15 years, if the respondent was the founder of the organization, and the organization's name or EIN number. The demographic question about role was one of the first questions asked (and was required to move forward) with board service, founder, and organizational EIN/name asked toward the end of the survey.

Another consideration for the decision to include a minimal number of demographic questions was based on the availability of other sources of nonprofit data about nonprofit leaders (e.g. gender, backgrounds, and skills) and organizations (e.g. size, age, and financial information). Regulatory, practitioner and academic sources such as the Internal Revenue Service, BoardSource, GuideStar, Foundation Search, the National Center for Charitable Statistics, the Midwest Center for Nonprofit Leadership at University of Missouri - Kansas City, and the Lilly Family School of Philanthropy at Indiana University are well regarded sources of nonprofit demographic data. Finally, because this was exploratory in nature, more demographics could be included in a future iteration.

Of the five demographic questions included, only two are used in this study, the respondent's role within their organization and the number of boards they have served on in the last 15 years. The researcher opted not to use the responses for organization EIN number or name, because only 96 represented unique organizations. For the founder 
question, only 19 respondents indicated that they were also the founder. Therefore, no analysis by founder or by EIN is included in the study.

Role is the main demographic variable, because the study focuses on nonprofit leaders and because of the nature of the leadership structure inherent in nonprofit organizations. Nonprofit organizations are considered corporations and must adhere to corporate law, and specifically in California, charitable corporate law. This law requires that all nonprofit boards have at least three members serving as chair/president, treasurer, and secretary (California Department of Justice, 2017). Therefore, the rationale behind the roles selected was based on the typical leadership structure of a nonprofit organization. Most nonprofit organizations also fill the role of vice president, so combined with the chair, treasurer, and secretary these four positions serve as the executive board committee.

Other roles included in this study were the executive (i.e. the most senior staff member), general board members (not serving in an executive committee position), advisory board, and "other." Participants were asked to select executive staff if they were the most senior paid staff for the organization. Two respondents selected "other", but one was re-categorized as an executive staff and the other was re-categorized as a board member, based on how they described their role. Three respondents selected the advisory or committee member option and are not included in the analysis since these positions do not have voting power, reducing the total number of viable responses to 186 .

For this study, respondents were asked to identify their role for the nonprofit organization that they chose to focus on when answering the survey questions. In other words, if a respondent was a board chair for organization $\mathrm{X}$ and an executive director for 
organization $\mathrm{Y}$, they could choose either role, but all of their answers must be related to their capacity in that chosen role for the corresponding tax-exempt organization.

Regarding the role variable, the researcher initially planned on analyzing the data using three categories: Executive (staff), executive committee (President, Vice President, Secretary, and Treasurer) and non-executive committee board members. However, because of the small number of respondents in some of the executive board positions, the distribution was skewed, therefore the respondents were collapsed into two categories: Executive and all board members. Using just two categories supported a more robust data analysis process and is the basis for analysis throughout the remainder of this study.

Figure 2.7 presents both sets of samples, first by the two roles board members $(N=104)$ and executives $(N=82)$ followed by the three role configuration, board member $(N=52)$, executive committee $(N=52)$, and executives $(N=82)$.

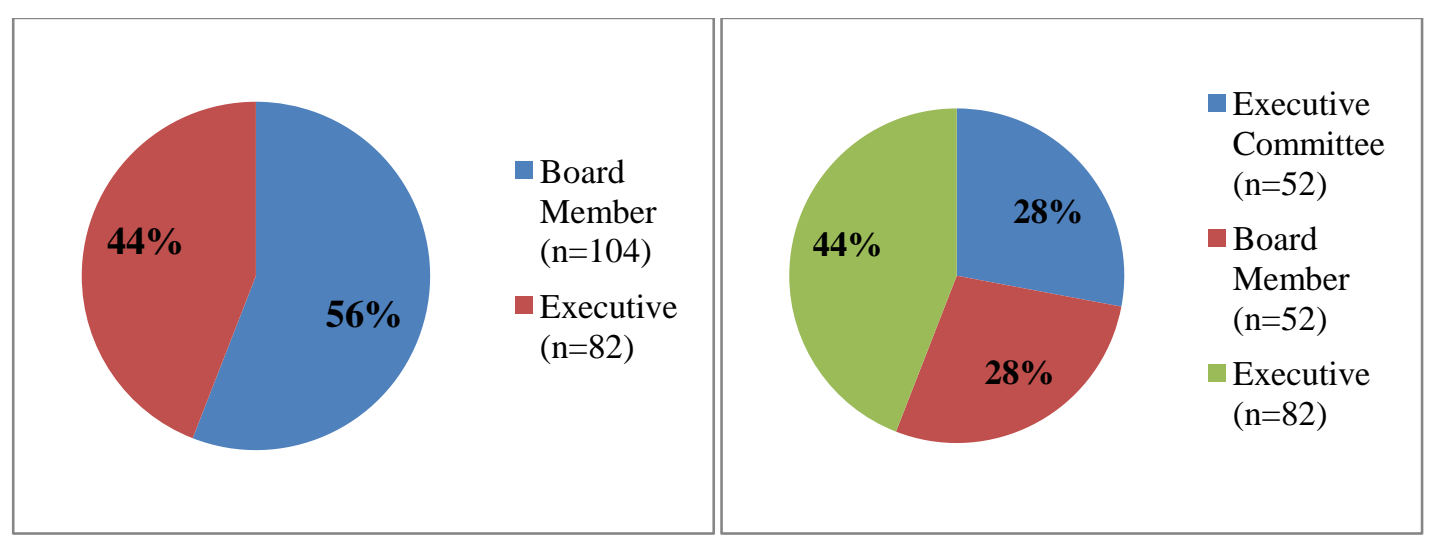

Figure 2.7. Percentages of respondents by two roles $(\mathrm{N}=184)$ and three role categories ( $\mathrm{N}=184)$.

Figure 2.8 presents the number of respondents by specific board member roles, board chair $(N=36)$, executives $(N=82)$, board members $(N=52)$, board secretary $(N=$ 4), board treasurer $(N=8)$, and board vice chair $(N=4)$. 


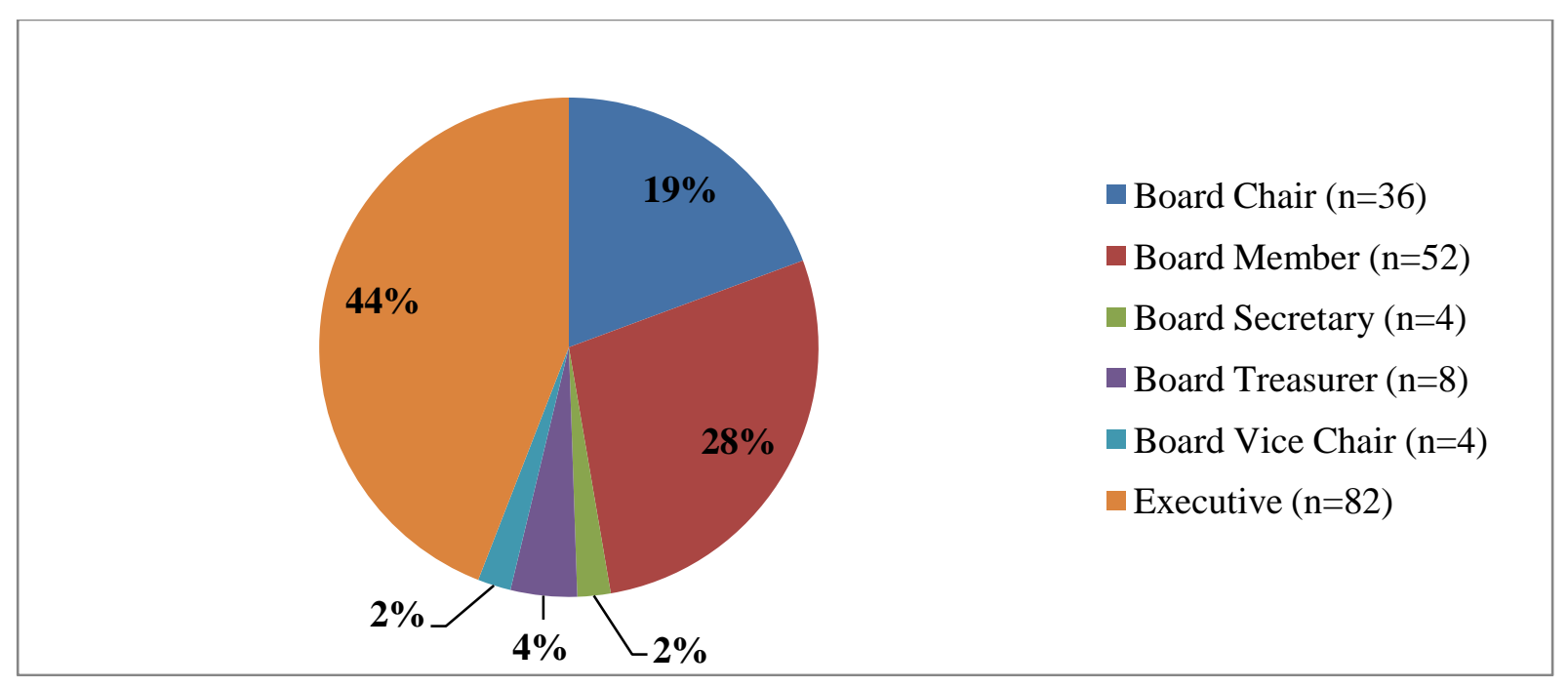

Figure 2.8. Percentages of respondents by board role $(\mathrm{N}=186)$.

With regards to the variable of board service (number of boards served in the last 15 years), the rationale behind this particular demographic was to better understand how the length of board experience might relate to fiduciary duty knowledge. Although the researcher has yet to find any longitudinal research that tracks a nonprofit leaders board service, she tapped into her nearly 20 years experience as a nonprofit practitioner and hypothesized that if a nonprofit leader had previous board service, they may have a greater awareness of fiduciary duties. As presented in Figure 2.9, 49\% of the respondents have served on one to two boards, $31 \%$ have served on three to four boards, $11 \%$ have served on five to six boards, and $8 \%$ have served on more than six boards. Because of the skewed distribution, some analysis was performed on a new variable that collapsed the four board service categories into only two. Notations are made throughout the dissertation to identify when categories were collapsed. 


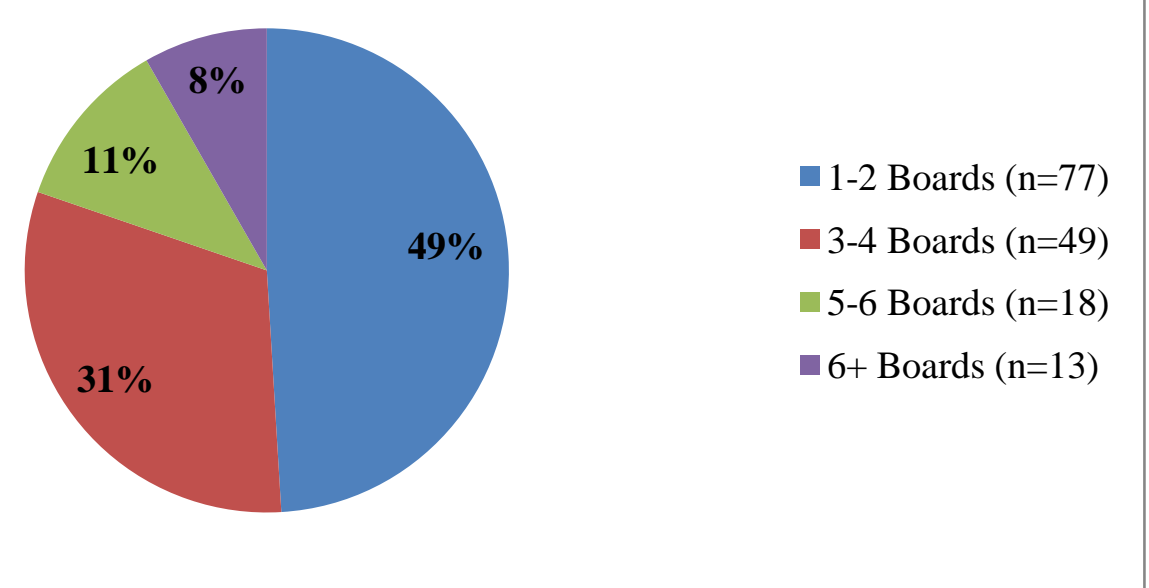

Figure 2.9. Number of boards served on in the last 15 years $(\mathrm{N}=154)$.

\section{Survey Instrument}

The survey instrument was developed using some elements from existing board assessment tools as well as practitioner and scholarly research related to board governance (Alliance for Nonprofit Management, 2017; BoardSource, 2017; California Attorney General, 2017; Corporation for National and Community Service, 2017; Hopkins, 2009; Jackson \& Holland, 2009; Nonprofit Association of Oregon, 2017; Overton \& Frey, 2002; Schwab Foundation for Social Enterprise, n.d.). Specific questions related to the duties of care, loyalty, and obedience that were not available otherwise, were developed by the researcher. The survey itself was created in Qualtrics, a survey software available free of charge to University of San Diego students.

During the testing phase, the researcher estimated that that the survey would take between ten and 15 minutes. However, after removing 41 responses that were outliers (less than 5 minutes and more than 30 minutes) the average amount of time it took for survey respondents was a little over 11 minutes as presented in Table 2.7. 
Table 2.7

Average Amount of Time to Take Survey

\begin{tabular}{ccccc}
$\mathrm{N}$ & Mean & Std. Dev. & Min. & Max \\
\hline 146 & 11.27 & 4.916 & 5 & 28.6 \\
\hline
\end{tabular}

Note. Time is presented in minutes. 41 outliers were removed that took less than 5 minutes and greater than 30 minutes to complete the survey.

\section{Constructs and Measurements}

The survey instrument was categorized into five main parts, however for this study, only three were included. The remaining two are intended for future analysis. The three parts were designed to answer the three constructs: (1) Nonprofit leader familiarity of fiduciary duties and actual knowledge of duties; (2) What types of external and internal sources do nonprofit leaders access to learn about their fiduciary responsibilities and; (3) The frequency with which nonprofit leaders apply their fiduciary knowledge in the performance of their governance activities.

\section{Knowledge Construct}

The first part of the survey focused on nonprofit leader fiduciary duty knowledge. For this section yes/no/don't know and four point Likert scale response options from not at all familiar to very familiar and disagree to agree were used. Questions included in this section allowed for a subjective measurements of familiarity of the fiduciary duties and objective measurements of actual knowledge. Respondents were provided with a brief description of each of the fiduciary duties and asked to rate their level of familiarity with each using a four point Likert scale of not at all familiar to very familiar. As the survey progressed, respondents were asked about their level of agreement with specific legal responsibilities related to the fiduciary duties, their understanding of the mission, and if they believed they had enough knowledge to carry out the organization's mission (four point Likert scale, disagree to agree). 
As mentioned earlier, knowledge questions can be sensitive and some respondents may inflate their answer to appear more socially desirable (Dillman, 2000). With this in mind, the researcher included a means to test respondents in order to compare how familiar nonprofit leaders believed themselves to be with what they actually knew. Ten questions related to legal responsibilities were displayed as a matrix with yes/no answer options for a total of ten possible correct answers. Of the ten questions, four were "false" questions that if they answered incorrectly, were not given a point. More about how these questions were coded and analyzed is included in chapter three.

\section{Source of Knowledge Construct}

The second part of the survey focused on what types of sources nonprofit leaders accessed to learn about their roles and responsibilities. This section included four point Likert scale response options from disagree to agree and never to always. Options included learning opportunities and tools that were provided by the organization (internal) or those that were available to the general public (external). For example, internal sources included a board manual or board orientation that a respondent might access internally within the organization itself. External sources included options such as websites, webinars, workshops and trainings that focused on nonprofit governance and oversight. For the internal sources, respondents were given the option to select all that apply and for external sources, respondents were given a three point Likert scale option, never, sometimes, and always.

\section{Application of Knowledge Construct}

The final part of the survey focused on subjective measurements related to the frequency with which nonprofit leaders applied their fiduciary knowledge in the 
performance of their governance duties. For example, respondents were asked how often they review materials in advance of the board meeting to demonstrate their application of the fiduciary duty of care. Respondents were given four point Likert scale response options that included disagree to agree and never to always.

\section{Psychometric Properties}

Prior to deploying the survey, face validity, meaning that at face value "a measure appears to make sense" (Vogt, 2005, p. 117), was approached by providing the survey instrument to seven nonprofit and research evaluation experts (Dillman, 2000). The experts included current and former nonprofit executive directors and board members, nonprofit consultants, and academics who provided feedback based on their roles as a nonprofit practitioner or researcher. Experts were asked to pay attention to survey aspects such as clarity of question, ease of navigation, relevance of answer options, and if the questions were focused on the constructs as they beta-tested the instrument prior to deployment. The face validity approach also supported content validity to ensure that the items included "accurately represent the thing being measured" (Vogt, 2005, p. 59).

In terms of construct validity, the questions were specifically related to each of the constructs being measured, knowledge, source, and application of the fiduciary duties of loyalty, care, and obedience. Each construct included questions developed by using language and expectations outlined in federal and California state regulations, corporate and charitable corporate law. Other sources utilized to develop questions were based on the literature and studies focused on board and organizational performance. The construct validity approach was helpful in establishing convergent validity as there was overlap with some of the literature and studies. 
In terms of sensitivity, the survey included multi-item scales and yes/no responses. Each scale provided face validity in that they corresponded to the duties and construct that were measured. For example, because one of the purposes of this study was to assess nonprofit leader actual knowledge of fiduciary duties, some questions were given a yes or no option as answer options, as if it were an actual test. Additionally, when asked about the frequency of application of fiduciary knowledge, the researcher opted for a four point Likert scale, rather than a traditional five or seven, in order to eliminate the option of a neutral response. Where appropriate, Cronbach's alpha was computed.

\section{Data Collection}

Data were collected using an online survey instrument as previously described. Prior to deploying the survey, Institutional Review Board approval was acquired from the University of San Diego (included at the end of this study). Once approved, a hyperlink for the survey was sent electronically to more than fifty personal and professional contacts and lists of individuals from San Diego nonprofits that the researcher had either consulted with or who have attended events where she had led a workshop or presentation. The email invitation to participate is included as (see Appendix B). Informed consent was provided to survey participants as the landing page of the survey and is included in the survey instrument itself (see Appendix A). Those who agreed to consent moved forward to the survey. Those who did not agree to consent were directed to a thank you page and were not allowed to take the survey. The survey was in the field for five weeks. At least three reminders were sent out during the course of the five weeks to those the researcher personally made contact with. It is unknown if those who found out about the survey through a second or third party received reminders or not. 


\section{Data Analysis}

Data was analyzed using IBM SPSS statistical software and Microsoft Excel. Descriptive statistics are used to present a summary of data in a way that identifies frequencies, means, medians, and standard deviation. Pearson Correlation analysis and Contingency Tables were used to identify relationships between variables.

After closing the survey, the raw data was downloaded from Qualtrics and cleaned by naming each variable, coding answers, and removing any duplicates and responses that had no data. During the cleaning process, new variables were added for the purposes of collapsing or describing variables. For example, after initial analysis, the role variable was collapsed first into three sub-groups (executive, board committees, and board members) and then into two sub-groups (executive and board members). Additional details are included in the proceeding chapters about the data analysis performed.

\section{Delimitations}

Delimitations are purposeful boundaries applied to a research study. As such, the geographic constraints are considered a delimitation. Nonprofit organizations exist in nearly every community in the United States, however, the researcher's nonprofit experience is primarily in the San Diego County region. Being in the San Diego region, working and consulting for, volunteering at, and engaging with the nonprofit sector for nearly 20 years, has allowed the researcher to build a considerable network of nonprofit practitioners, researchers, and organizations. As a result, a purposeful decision was to conduct this study in this region in order to begin to build the knowledge in a somewhat “controlled" environment. 
Another delimitation to this study is that it focuses only on the legal aspects of accountability as they relate to the fiduciary duties of care, loyalty, and obedience. Nonprofit leaders are expected to fulfill a wide range of roles and responsibilities intended to support fulfilling the mission. As such, the researcher chose to bound the study in very narrow terms, in terms of legal accountability, using the fiduciary duties, which are widely accepted and recognized standards of conduct and behavior by government, practitioners, and academics. Although it is a small piece of the puzzle, it is the researcher's belief that nonprofits who understand their fiduciary responsibilities make better decisions, which in turn satisfied legal accountability demands.

\section{Limitations}

As with all studies there are limitations and this study is no exception. Limitations are design flaws and potential weaknesses in the study. For this study, limitations revolve around generalizability and replicability, specifically in terms of the sample and the survey instrument. The study alone is not enough to determine whether the results would be similar in other geographic regions. Without additional testing of the survey instrument, the study can only serve as a starting point for future research that points to, but not verify, trends or phenomena.

The first limitation worth noting is related to the sample. Given that the survey was open to any individual that either served as a voting nonprofit board member or as the executive located in San Diego County, there is no way of knowing how many potential respondents make up the population or to verify that those who responded fit the eligibility criteria. 
The second limitation is the survey instrument itself. It was developed for this study and can be improved upon by changing some of the scales and the wording of questions. For example, different four point Likert scale options were given for the fiduciary duty constructs, executives were given disagree to agree, whereas board members were given never to always. Additionally, self reported data can be problematic because respondents may want portray themselves in a positive light and not admit what they do not know. This aspect of social desirability may have either inflated respondents answers or may have prevented other participants from taking the survey if they felt that they may not have the appropriate knowledge.

The instrument can be further improved upon by adding actual measures of some of the theoretical frameworks used in this study such as institutionalism, isomorphism, and performance that are discussed in chapters four and five. In chapter three, with regards to the bylaws questions, without any confirmation that the item was actually in the organization's bylaws, this set of questions is purely exploratory. Furthermore in chapter three, for the actual knowledge of the duty of obedience construct, only one question was included, ensuring that compliance with state and federal regulations is a legal responsibility. For future iterations of the assessment tool, it may be helpful to include additional questions related to this construct.

In chapter five, two different types of answer options were used for board members and executives and as such, the results for both roles could not be compared in an equal manner. Furthermore, for the duty of obedience construct in chapter five, only one question was included that focused on disclosing conflict of interest. For future 
iterations of the assessment tool, it may be helpful to include additional questions related to this construct.

Although bias can be seen as a limitation, it is also a strength. As mentioned previously, the researcher is a practitioner with knowledge and perspective that is useful in creating something that benefits practitioners. As such, the study was conducted in a way that considered how helpful each piece of data would be for an executive or board member. Yet, a limitation would be that as a new academic, the researcher is still learning appropriate theories, frameworks, quantitative analysis techniques, and terminology that will be used in further research.

Finally, given the researcher's nonprofit experience, special attention was paid during the design, implementation, or analysis phases of this study to avoid any bias, another potential limitation. This was carried out by regular check-ins with colleagues and the dissertation chair. Furthermore, no conflict of interest, such as a reporting relationship, contract, or any relationship with the researcher was evident that may have imparted bias on the research study itself.

This is a pilot study, and as such there are several changes that need to be made prior to another deployment, as mentioned previously and other changes will be made as practitioners, academics, and regulators are engaged. There is no one single assessment that can adequately measure knowledge, application, and source of fiduciary duties. However, what this study does is it begins the conversation about basic responsibilities and establishes baseline data with which to build on. Many more studies need to happen that include other methodologies including interviews, observation, and pre and post tests to name a few. 


\section{CHAPTER 3: KNOWLEDGE OF FIDUCIARY DUTIES}

The nature of nonprofit governance is one filled with challenges and tensions, particularly in terms of legal accountability. For example, federal and state regulations provide guidelines as to what nonprofit leaders are responsible for in the governance of tax exempt organizations through the legal standards of the fiduciary duties of care, loyalty, and obedience, but over time additional expectations have been placed on nonprofit leaders. Additionally, nonprofit leaders are expected to perform their duties in a manner that upholds their legal responsibilities, but no standardize process exists that ensures that they have the basic knowledge of what their responsibilities are.

Furthermore, while legislation is important in that it mandates certain behaviors and requirements, it is reactive and varies depending on the state and the resources available for enforcement. Other tensions can be seen in the voluntary nature of nonprofit service. Nonprofit leaders are volunteers and as such are given a great deal of leeway in the performance of their duties creating tensions between expectation of service and reality. Finally, tensions are found in the democratic idea of pluralism that allows people to create nonprofits to meet a variety of public needs, resulting in the need for more people to fill governance roles in an ever-expanding nonprofit sector.

Given the many challenges and tensions, the fiduciary duties provide a consistent, universal set of standards that all tax exempt organizations must fulfill. Regardless of the mission, size, or location, when accusations or concerns of negligence or wrongdoing surface, every decision and action nonprofit leaders make will be applied against the standards as set forth in the fiduciary duties. In essence, the fiduciary duties level the playing field in terms of legal accountability in the performance of governance duties. 
Ebrahim (2010) suggests that a mechanism of accountability includes knowledge. What this study provides is a means to assess the legal dimension of nonprofit accountability at the governance level, specifically nonprofit leader knowledge of fiduciary responsibilities. The broader purpose of this study is to establish baseline data about nonprofit leader knowledge of their fiduciary responsibilities and is categorized into three areas: nonprofit leader knowledge of fiduciary duties; the types of sources nonprofit leaders access to learn about their fiduciary responsibilities; and application of knowledge in nonprofit leaders' governance activities as illustrated in Figure 3.1.

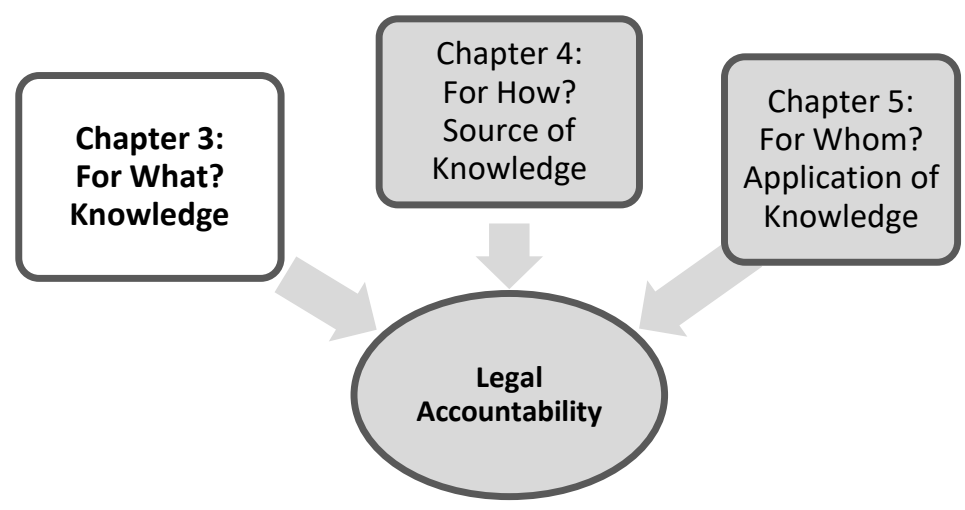

Figure 3.1. Framework for Legal Accountability.

In looking at how knowledge will be measured, Miller's (1990) model of competence, as illustrated in Figure 3.2 provides a framework. The first level, "knows", refers to an individual's ability to recall specific elements. For this study, knowledge is assessed by asking respondents about specific elements of each of the fiduciary duties first what they believe they know (i.e. self-reported) and then they are assessed by what they actually know. 


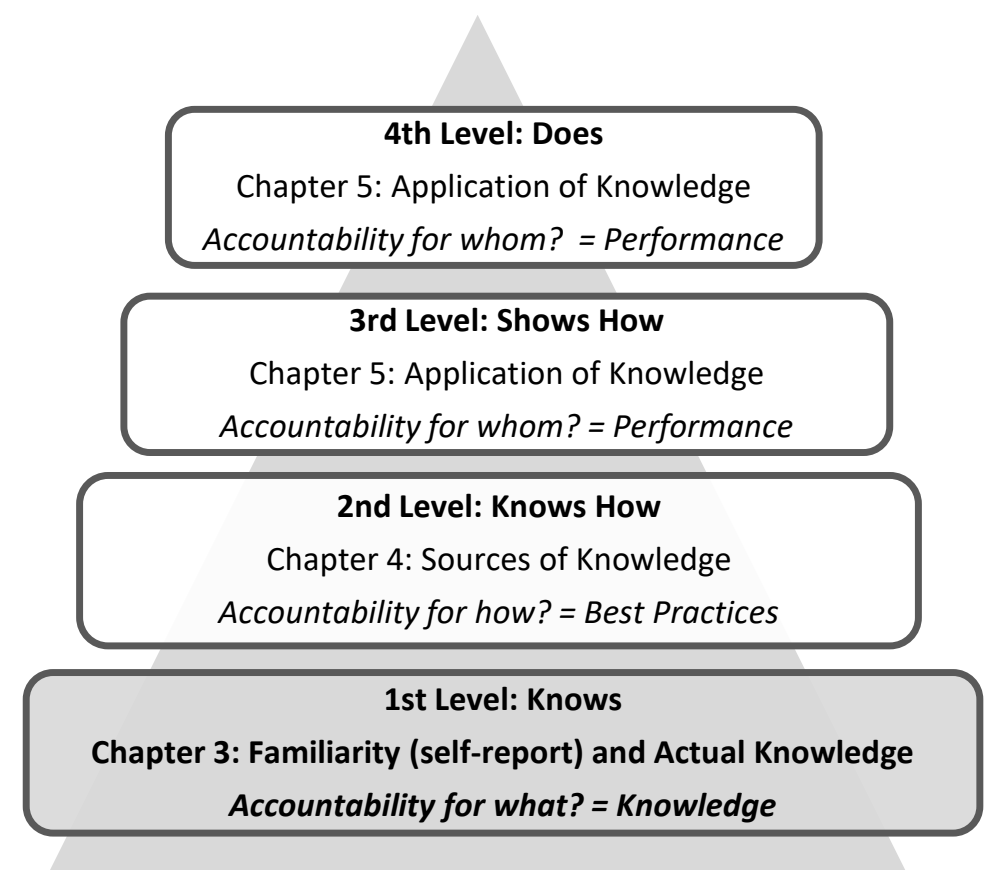

Figure 3.2. Constructs and Legal Accountability adapted from Miller's framework for clinical assessment model in The assessment of clinical skills/competence/performance, Academic Medicine, (1990).

This chapter focuses on the first strand of research, nonprofit leader (board members and executives) knowledge of fiduciary responsibilities as a means to meet legal accountability. The findings suggest that nonprofit leaders believe they have enough knowledge to govern, but in reality, may not have correct knowledge of what their fiduciary duties entail. I begin this chapter reviewing accountability for what that is followed by a discussion about the nature of the nonprofit sector that includes its characteristics and the legal roots. Next, a discussion on board governance provides a background about the evolution of nonprofit governance with a detailed discussion of the fiduciary duties of care, loyalty, and obedience to provide context about what regulators expect of nonprofit leaders. Following the regulation and enforcement aspects, I present the results of related to nonprofit leader knowledge of fiduciary duties. Finally, I offer a discussion of the results and implications for future research. 


\section{Accountability for What?}

In Ebrahim's (2010) facets of accountability, four areas are important for the discussion of accountability, finances, governance, performance, and mission. Financial accountability is typically demonstrated through compliance and disclosure. Submitting required reports such as the annual tax return, quarterly employment taxes, and allowing the public access to audited financial statements are examples of compliance and disclosure. The duty of obedience focuses on compliance and ensuring that the organization upholds state and federal laws. As such, organizations that actively comply with reporting requirements are fulfilling their legal accountability by upholding their fiduciary duty of obedience.

Performance is another means to meet accountability that focuses on how an organization goes about fulfilling its mission. Engaging in a strategic planning process, identifying goals, and establishing metrics for success are useful approaches to performance. However, performance in and of itself is not an expectation that is outlined in the fiduciary duties. The exception to this is in the duty of obedience, which holds the board of directors responsible to evaluate the performance of its chief executive. Because executives perform the day-to-day operations of the organizations, they are entrusted with resources. Therefore, boards who regularly evaluate their chief executive meet the duty of obedience and demonstrate legal accountability by ensuring that resources are used to fulfill the mission.

Similar to performance, fulfillment of the mission is a means nonprofits demonstrate accountability. Because nonprofit status is given to organizations that meet an approved charitable, scientific, educational, or religious purpose, they are provided 
financial benefits in return, in the form of tax incentives. Tax incentives are a product of U.S. legislation which allows tax deductibility for donations made by the public, for tax exempt entities classified as c3, and tax free revenues for all tax exempt entities. Because donations and tax free revenues reduce the amount of money the IRS can collect, tax exempt entities in essence are subsidized by the U.S. government and the expectation is that nonprofits use "public" money for public good (i.e. fulfillment of the mission). Therefore, nonprofits who can demonstrate that they fulfill their mission satisfy legal accountability.

The final facet of the accountability model is governance which according to Ebrahim, focuses on "how the organization [boards and executives] raises and spends money, follows donor intent, and whether it is in compliance with the law" (as cited in Renz, 2010, p. 105). Each fiduciary duty is geared toward those who oversee and manage tax exempt entities and provides guidance that nonprofit leaders can use to support their governance activities. As such, the fiduciary duties provide a useful measurement of governance.

Of the four facets, finances, mission, and governance are more relevant to what nonprofit leaders are legally responsible for in terms of their fiduciary duties. Because the duties of care, loyalty, and obedience focus on how the "owners" of a nonprofit use resources in order to fulfill the charitable mission performance is less of a consideration. However, performance of the executive is a legal responsibility for the board to fulfill their fiduciary duty of obedience, as is discussed later. Although Ebrahim's (2010) idea of performance for accountability is focused on more of an organizational performance, it is relevant to the discussion about nonprofit leaders and how they meet legal 
accountability. As such, nonprofit leaders demonstrate legal accountability by knowing the fiduciary duties of care, loyalty, and obedience to fulfill their governance responsibilities.

\section{Nonprofit Characteristics and Legal Roots}

\section{Characteristics}

What is unique about nonprofits is that they have a great deal of freedom to engage in a wide variety of issues. Nonprofits provide programs and services such as those relevant to individuals' religious, cultural, and professional identities; to groups affected by certain types of diseases and disorders; to communities in need of transformation; and to nations in need of aid. Fishman, Schwarz, and Meyer (2015) attribute this freedom to the idea of pluralism which "allows individuals and groups to pursue goals that they formulate" (pg. 5). As utopian as pluralism sounds, it has a dark side. Given the more than 1.5 million tax exempt entities, there is a current debate about the sheer size of the sector. As more and more ideas turn into new nonprofits, competition for financial, physical, and human resources increases.

Pluralism impacts nonprofit governance. Given that all tax exempt entities are required to have directors and officers overseeing the organization, typically without compensation, the need for people to fill governance roles increases. This might prove challenging given that in the 10 year period from 2002 to 2012, the number of nonprofit organizations increased 8.6 percent, more than 125,000 organizations (Worth, 2017, pg. 25). This increase was followed by another jump after the IRS introduced a streamlined, shorter version of the 1023 Application for Tax Exemption, (1023 EZ), in 2013 creating a deluge of new requests for tax exempt, nonprofit status. Between July and December of 
2014, on average, the IRS approved 10,000 new applications for tax exemption each month (Wyland, 2018).

Not only did the 1023 EZ potentially create more demand for board members, it was also a source of contention. Many nonprofit leaders voiced concerns that the it lacked transparency, eroded public trust, and allowed the IRS to fail in their "...primary obligation of preventing ineligible organizations and perhaps bad actors from receiving and exploiting tax-exempt status for personal gain... with every application processed." (Council of Nonprofits, n.d.). This concern was based on the fact that the new application opened the floodgate allowing any and all groups to become tax exempt without any explanation as to their governance and oversight processes or assurances against the misuse of funds (Council of Nonprofits, n.d.).

\section{Legal Roots}

At its roots, nonprofits are about people helping people. Throughout history, we see many examples of charitable work that spans thousands of years and across multiple continents. In the third century BC, the Hebrew tribe of Levi was supported by their fellow tribes so that they could perform their priestly duties in the temple (Holy Bible, 1986). Other examples come from ancient Greece and Rome with wealthy citizens supporting civic life through their subsidizing of city infrastructure and municipal projects (Robbins, 2006). China enjoyed a long history of charity prior to communism with its commitment to helping each other as expressed in an ancient Chinese saying, "to have virtuous citizens who are kind to their neighbors, this is a precious treasure for a country" (Chan, 2015). Although service to mankind transcends time, culture, religion, and geography, the legal framework that bounds nonprofit organizations of the $21^{\text {st }}$ 
Century is based more on western traditions of charity and philanthropy, specifically English charitable law.

In 1601, England passed the Statute of Charitable Uses and the Poor Law which was a turning point for charitable work in that it articulated the roles and boundaries of the British government and the Church of England (Fremont-Smith, 2004; Worth, 2017, pg. 21). Up until this time, property was the primary mode of funding charity work and with the property owner who had the authority to use it in support of the charitable purpose they deemed fit (University of Pennsylvania, 1904). Because religious institutions administered most of the charity work, the concern was that the church would garner too much power and influence as they acquired more land. As such, the new laws offered clarity as to the types of acceptable charitable purposes and established the idea that private charity and the state should work in partnership (Fremont-Smith, 2004). The new laws also set the tone for accountability with regards to those who were entrusted with the resources to fulfill charitable purposes, thereby providing the foundation for nonprofit governance regulations of today.

English law provided the basis for charitable work, but it was the attempted takeover of Dartmouth University in 1816 which settled the idea that public work should be governed by the public, not the private or government sectors, as well as established the role of the state for the oversight in corporate affairs. At the time, English Common Law was still important to the young republic because of its focus on corporate property rights since the newly adopted U.S. Constitution made no provisions regarding corporations. With the lack of legal clarity, coupled with the newfound rights for citizens to freely assemble, it seemed "reasonable to argue that nonprofits and their boards were 
guardians of citizens' private rights" (Dobkin Hall, 2003, pg. 11). To settle the issue of Dartmouth, Chief Justice Marshall decided that a public institution's mission, or the purposes for which they were formed, should determine how they are governed thus protecting charitable institutions from legislative interference in their decision-making process (Dobkin Hall, 2003). His decision was key in that it framed public policy by combining English Charitable Law which protected the rights of corporations and the U.S. Constitution which protected the rights of citizens. Combined, Marshall's decision became the basis for nonprofit governance by shaping accountability expectations and responsibilities of citizens as corporate owners and directors.

\section{Nonprofit Governance}

Federal and state regulations require tax exempt organizations to be governed individuals. Often referred to as boards of directors or trustees, board members are typically volunteers and are tasked with making decisions on behalf of, and to act in the best interest of, the organization. Because of the pluralistic nature, nonprofits have the flexibility to create boards that reflect their missions. For example, nonprofits who work closely with their community may choose to have a board member who represents the community or someone who has been a beneficiary of services. Additionally, nonprofits may select board members who can provide specialized knowledge or skills if the mission focuses on disease prevention, the environment, or advocacy.

The composition of boards is an interesting area of scholarship that links organizational performance to board member expertise, training, and professional background (Andersson \& Renz, 2009, Tschirhart, et al. 2009). Although boards are often made up of accomplished professionals in their fields they may lack experience 
related to the governance aspects of running a nonprofit (Preston \& Brown, 2004). Each nonprofit leader brings to their role varying degrees of knowledge and skills and when these individuals come together, as the legally responsible oversight body for a nonprofit organization, the combined knowledge may or may not be adequate enough to make decisions about resource that fulfill their fiduciary duties.

What creates tension is the requirement for nonprofits to have board members but without any standardized assessment to certify board members understand their fiduciary responsibilities. And, it seems that there is little to no scholarship that explores the fiduciary aspect of governance that either explores nonprofit leader knowledge of fiduciary duties or how that knowledge may impact their oversight role. Dobkin Hall (2003) offers that, because what boards are responsible for has never been fully spelled out, but that they "are often unpleasantly reminded" of their duties (p. 3). These reminders have materialized over the past several decades with high profile legal cases and news reports of nonprofit mismanagement. Adding to the tension is the evolution of board roles and duties over time, contributing to the varying degrees of knowledge.

\section{Boards in the New World}

With the discovery of the New World, the earliest U.S. settlers built charitable institutions such as hospitals, schools, and churches in their new homeland (Fishman, Schwartz, \& Mayer, 2015). As the colonies grew, so did the need for control as was seen in the creation of the first American board by the Massachusetts Bay Company. What began as a joint stock trading company created by the English crown to support colonization in the New World was taken over by religious leaders in 1631 to establish 
the first charitable trust and in the process, established the idea of self-governance and independence from government (Zeichner, n.d.).

With the example of the Massachusetts Bay Company, other religiously oriented institutions such as Harvard and Yale were instrumental in the development of the contemporary nonprofit governance model of today. Harvard's contribution was distinguishing "between the persons who might serve as officials of the corporation and their role as officers" by creating two separate governing bodies: one that was selfperpetuating that focused on the academic issues of the institution and the other made up of appointed members who answered to the church and state (Dobkin Hall, 2003).

Yale was established in 1723 in reaction to Harvard's increasing liberalism and was responsible for creating the collective governing body model. The idea that one body was responsible for oversight of the entire institution was warranted because of the belief that trustees would act in good faith was based on their duty to God (Dobkin Hall, 2003). Although these were significant contributions, there was still the tension of control, because many board members were either elected officials, ex officios, clergy, or administrators who had a vested interest in the organization. The question then was "who should control American culture" (Dobkin Hall, 2003, pg. 17)?

\section{Boards in the New Era}

As America became industrious and generated wealth, the idea that charitable work should be governed by those outside of government, religion or academia was an impetus for stakeholder representation. Educational institutions were the first to embrace public representation by adding businessmen and lawyers to their boards in an effort to woo their financial resources in support of the mission. However, this approach was 
problematic, because of the stark differences in philosophies between the new and old leadership and differences in loyalties and allegiances. Old leadership focused on "diffusion of knowledge" whereas business leaders focused on "acquisition of wealth" (Dobkin Hall, 2003, p. 19).

Beginning in the mid-1920's, U.S. President Hebert Hoover's modernization of government was instrumental in establishing improved governance principles and practices. For both private for-profit and public charitable entities, attention was given to developing resources to improve board performance and address "issues as accountability, conflict of interest, fiduciary prudence, and the duty of loyalty"(Dobkin Hall, 2003, p. 20). By the 1940's, the idea of professionalization was introduced as a dimension of corporate stewardship. The taxation and corporate structure of the charitable sector began to take shape as well and by the mid-1960's more than 250,000 charitable organizations were registered with the Internal Revenue Service (IRS) (Dobkin Hall, 2003).

With the growth of the charitable sector concerns over the wealthy having influence over elected officials and legislators began to raise red flags as financial support for candidates was carried out via their own charitable foundations. The U.S. Congress had already set limits on lobbying activities by charitable organizations in the Revenue Act of 1934 in that "no substantial part of its activities shall be used to carry out propaganda" or "influence legislation", but Congress enacted even tighter controls with the Revenue Act of 1954 that added charitable organizations were prohibited from "publishing or distributing of statements for any political campaign on behalf of any candidate for public office" (Harris, 2016, p 1). Foundations came under more scrutiny 
when Congress enacted the Tax Reform Act of 1969 creating specific corporate structure and governance rules for private foundations (who funded charitable work) and their trustees that were more stringent than their charitable counterparts (who carried out the work) (Arnsberger, et al, 2008). More recently, legislation was passed intended to improve transparency, accountability, and compliance for all tax exempt entities, but mainly at the state level. In California, the Nonprofit Integrity Act of 2004 and the Nonprofit Revitalization Act in New York in 2013 were received with wide support.

\section{Expectations of Nonprofit Leaders}

\section{The Fiduciary Duties}

Nonprofit law is based in corporate law which is "the body of laws, rules, regulations, and practices that govern the formation and operation of corporations and regulates legal entities that exist to conduct business" (Legal Career Path, 2018, p. 1). As a subsection of corporate law, nonprofit law deals with charitable corporations and focuses on decision-makers, in this case board members and executives, and their fulfillment of a charitable mission. Corporate law has identified three comprehensive duties that directors and managers are responsible for which are also applied to nonprofit corporations - the duty of care, loyalty, and obedience. In California, tax exempt entities abide by California Charitable Corporate law which applies the fiduciary duty concepts to the expectations of officers, either board members or executives, who oversee California charities. In California officers are considered fiduciaries which requires them to, "control the corporation in a fair, just, and equitable manner" and "refrain from doing anything that harms the corporation" (California Department of Justice, 2017, p. 55). 
The three main duties that nonprofit boards of directors are held responsible for are care, loyalty and obedience as presented in Table 3.1. Combined, these duties provide guidance related to the expectations of how boards will govern in a manner that ensures decisions are made for the organization's best interest and promote transparency and good stewardship of resources. The duty of care requires board members to be actively engaged in the organization by attending board meetings regularly, reviewing organizational documents, and participating in the decision making process. The duty of loyalty requires board members to put the organization's interests first by avoiding conflict of interest and any dealings that may personally benefit a board member. The duty of obedience requires board members to comply with state and federal regulations as well as with organizational policies and procedures.

Table 3.1

Nonprofit Leader Fiduciary Duty Responsibilities

Duty of Care: Engagement, Duty of Loyalty: Procedural Attention, Informed Process of Aspects of Transactions and Decision-Making

- Attends board meetings

- Reviews information in advance in preparation for board meetings and to inform voting

- Exercises independent judgment

- Regularly reviews finances, policies, and executive performance
Duty of obedience: Legal Compliance

Self Interest

- Discloses conflict of interests and potential self-benefit

- Avoids organization resources for personal use

- Maintains confidentiality
- Ensures compliance with state and federal requirements

- Reviews and understands corporate governance documents including bylaws

- Makes decisions that align with tax exempt mission

Note. Data is a compilation of Fishman, Schwartz \& Mayer, 2015; Fremont-Smith, 2004; Hopkins, 2009.

Duty of care. The duty of care revolves around engagement and according to Hopkins (2009), requires that a director is informed and "discharge his duties in good faith, with the care than an ordinarily prudent person in a like position would reasonably believe appropriate under similar circumstances" (p. 19). For board members and 
executives, fulfilling the duty of care means regularly attending meetings, reviewing materials prior to meetings, and accessing the right sources of information in order to make informed decisions.

We see a tension in fulfilling the duty of care in terms of accessing the right information for organizations with an executive. Both the directors and the executives are responsible to make informed decisions based on the appropriate information. However, board members tend to defer to and rely on the executive for information outside the scope of regular board materials such as financials, minutes, and committee reports. Therefore, if the executive is providing information to the board, they are held responsible to ensure that the board receives the appropriate information in a timely manner and the board is held responsible to ensure that they are receiving the appropriate information. There have been cases where the executive intentionally withheld information from the board and ultimately, the executive was found liable (see In Re Lemington Home for the Aged in Fishman, Schwartz, \& Mayer, 2015, p. 139-142).

Duty of loyalty. The duty of loyalty revolves around conflict of interest and according to Hopkins (2002) the basic legal principle is that "the director shall not use a corporate position for individual personal advantage" (p. 29). In order for board members and executives to fulfill the duty of loyalty they must acknowledge and deal with conflict of interests and maintain the confidentiality of organizational information. However, the duty of loyalty can be interpreted to mean more than just financially benefiting from organizational resources. Jan Masaoka (2010), a widely regarded nonprofit practitioner offers a multi-dimensionality approach to conflict of interest that goes beyond a board member who might benefit from a contract for services. Potential conflicts of interest 
could be more subtle such as a board member who also serves on a competitor's board or a board member who receives services as a client (Masaoka, 2010). Conflict of interest and private benefit have been cited in numerous court cases where board members and executives were found liable (see Alephi v. Diamandopoulus p. 162-168, Church of Scientology v. California Commissioner, p. 417-423, Nixon v. Lichtenstein, p. 152-155, Madden v. Commissioner, p. 712-718 in Fishman, Schwartz, \& Mayer, 2015)

Duty of obedience. The duty of obedience revolves around compliance of state and federal laws as well as the policies and procedures adopted by the corporation itself (Fishman, Schwartz \& Mayer, 2015). In order for nonprofits leaders to fulfill their duty of obedience, they must ensure that the organization fulfills its charitable purpose, submits required reports to state and federal agencies, ensure that taxes are paid (e.g. employment), and that internal policies and procedures such as the bylaws are followed. Palmiter (2010) recounts that the duty of obedience was the primary focus for corporations in their earliest forms, but has received less attention with the rise of additional corporate reforms and regulations. However, for nonprofits the duty of obedience is essential in that it requires organizations to focus on their charitable mission, the very reason they are given the legal tax exempt status. What this means is that nonprofit leaders must not engage in activities that are "ultra vires", those that go beyond the scope of their mission (Fishman, Schwartz, \& Mayer, 2015, p. 181). Examples of ultra vires activity includes nonprofits that add programs and services that may earn additional revenues, but are not essential in the fulfillment of their missions such as selling t-shirts or advertising space. This idea of commercialization has been the basis for several court cases where directors and executives found liable for failure to fulfill the 
duty of obedience, (see Presbyterian and Reformed Publishing Co. v. Commissioner, p. 537-543 and United States v. American College of Physicians in Fishman, Schwartz \& Mayer, 2015).

\section{The Fiduciaries}

For nonprofit organizations, the board of directors and to the same extent the executive, fills the primary role of governance and are responsible to ensure that all resources are in place and used to fulfill the mission along with compliance of state and federal regulations and requirements. Often they are referred to as board members or officers, but legally they are collectively referred to as fiduciaries. The root meaning of the term fiduciary is trust and as mentioned earlier, English law used the term trustee to define the relationship of someone entrusted with the use of property on behalf of a beneficiary (Fishman, Schwartz, \& Mayer, 2015). However, nonprofit leaders of today are entrusted with a more than just property as they oversee the use of a variety of resources to fulfill a charitable mission including financial, physical, human, and intellectual.

There is an assumption that the nonprofit sector can do no wrong and that those who serve as nonprofit leaders have special qualities. However, Salamon notes that the nonprofit sector is romanticized with a "myth of pure virtue" (as cited in Gibleman \& Gelman, 2001, p. 63) and that the public places extremely high expectations on nonprofit leaders. Fremont-Smith (2004) elaborates on this idea with her notion that since the organization is meant to do good the people will do good while Fishman, Schwartz, and Mayer (2015) note that "a trustee is held to something stricter than the morals of the marketplace" (p. 120). Yet, we know that nonprofit leaders are not immune to bad 
behavior as evident in legislation enacted by the U.S. Congress at the turn of the $19^{\text {th }}$ Century. The Revenue Act of 1909 introduced language prohibiting any individual from benefitting from organizational resources, i.e. private inurement (Arnsberger, et al, 2008) which points to the need to curb fraudulent activity of the time that continues to today as evident in the stories of nonprofit mismanagement.

Boards. In the United States, nonprofit organizations must be incorporated and registered with both state and federal authorities. As part of the registration process, nonprofits are required to include the names of the individuals who will serve in the board roles of president, secretary, treasurer and vice president. This sub-set is referred to as the executive committee and along with general members are either appointed or elected as the fiduciary overseers of the organization depending on how the bylaws prescribe the nomination and election process. Although the United States is known for its generosity and volunteerism, asking people to spend time to serve on a board of directors is sometimes a challenge. A recent national survey (BoardSource, 2017) of more than 4,000 nonprofit board chairs and executives, reports that the average board size has decreased from 19 in 1994 to 15 in 2017 (pg. 17). The decrease may be attributed to organizations proactively reducing the number of board members based on the needs of the organization or it may be reactive as a result to the lack of board recruitment. However, more than likely, it is a combination of proactive and reactive reasons along with a variety of others.

Beyond the legal fiduciary responsibilities, boards are asked to perform other duties such as a fundraiser, community advocate, or industry expert. However, these are not legally required as the fundamental duty of a board member is to direct the work of 
the organization, not engage in the day-to-day activities. In this oversight capacity, the primary function of the board is to ensure that the resources are in place and allocated such resources, so that the organization fulfills its charitable mission. The fiduciary duties establish a solid foundation for board members to fulfill their oversight roles. Furthermore, board members who are engaged, understand their legal responsibilities, and put the interests of the organization above themselves are poised to fill additional roles to fulfill the mission.

Executives. Executives are considered agents of the organization and are responsible for the day-to-day management of the organization, which gives them a considerable amount of influence and responsibility. Executives are appointed or hired, by the board of directors, report directly to the board, and are relied on by the board for information about the organization. Typically, executives are paid staff, but in the case of all volunteer organizations, they may serve in the executive capacity without pay. Regardless of the compensation arrangement, any individual who has been given executive responsibilities to manage the day-to-day activities is bound by many of the same requirements as boards and share in the governing responsibilities (FindLaw, 2016; Fishman, Schwartz, \& Mayer, 2015).

Because executives have access to resources, the law pays particular attention to their compensation. Executive compensation must be determined prior to employment and decided by the board based on comparison of similar organizations, the market, organizational needs, and capacity (Fishman, Schwartz, \& Mayer, 2015). Executive performance must be evaluated by the board of directors to ensure that governance decisions are being carried out by the management. However, according to a national 
study reported that only $60 \%$ of the organizations surveyed conducted annual board performance of the chief executive (BoardSource, 2017, p. 52). Conducting performance and evaluation of the chief executive ensures that compensation is appropriate and the executive is carrying out the mission of the organization which allows both the executive and board member to fulfill their fiduciary duties of obedience.

\section{The Regulatory Environment}

\section{Liability}

Federal and State regulators are aware that nonprofit boards are made up of volunteers and serve in unpaid positions and understand that if the legal requirements are too burdensome, no one would want to fill the role. An interesting example of the tension of the voluntary nature of board service is the case of Pepperdine University. In 1931, George Pepperdine donated $\$ 3$ million of his personal fortune to support the establishment of Pepperdine College in Los Angeles. More than a decade later in 1948, the college sued its founder when it faced more than $\$ 500,000$ in debt after a series of bad investments made by Mr. Pepperdine while he served as the President of the board. The court ultimately dismissed the case, since it was the states' responsibility to bring charges against a charitable entity and because of the lack of evidence that Mr. Pepperdine acted in an intentional, illegal manner. Although no one was charged, the Pepperdine case set a precedent of leniency toward nonprofit directors who "are essential volunteers, and aggressive attempts to enforce their responsibilities are inappropriate and will discourage individuals from board service” (Fishman, Schwartz, \& Mayer, p. 127).

The general expectation is that board members and executives will act on behalf of the best interest of the organization. However, sometimes board members and 
executives make bad decisions either out of negligence or willful intent. Given that board members and executives are responsible for organizational resources and serve voluntarily, they have a certain amount of protection from liability. At the federal level, board members are covered under The Federal Volunteer Protection Act (FVP) that was enacted by the U.S. Congress in 1997 to

[1]imit the liability of volunteers if they meet the following criteria: (1) the volunteer was acting within scope of her responsibilities at the time of the act or omission: (2) the volunteer was properly licensed, certified, or authorized by the appropriate authorities for the activities or practice in the state where the harm occurred: (3) the harm was not caused by willful or criminal misconduct, gross negligence, or reckless misconduct, or a conscious, flagrant indifference to the rights or safety of the individual harmed by the volunteer: and (4) the harm was not caused by the volunteer operating a motor vehicle, vessel, aircraft, or other vehicle for which the state required an operators license and insurance (Fishman, Schwartz, \& Mayer, 2015, p. 146).

Nonprofit organizations that have the financial resources to do so can purchase

directors and officers insurance (D\&O). This type of insurance protects the organization and provides additional coverage for paid executives. Organizations decide on their own how much insurance coverage they need and what they can afford. The FVP and D\&O insurance are important because they legally allow the use of financial resources (that were otherwise intended to support the charitable mission) for indemnification purposes to protect the directors and executives. Indemnification is the "payment by an organization of a director's legal costs, judgments, settlements, and other expenses arising out of litigation and theoretical legal action from a director's service to the corporation" (Fishman, Schwartz, and Mayer, 2015, p. 147).

The FVP is based on the law, which protects volunteers from misconduct and acts that are not illegal in nature. If a board member is found guilty of committing an illegal 
act, the FVP is invalid. The D\&O insurance can be used because is an agreement between the organization and the insurance company and the organization decides how much liability they are willing to realize. With the number of high profile cases of mismanagement, more and more nonprofits are looking at $\mathrm{D} \& \mathrm{O}$ insurance as a means to protect their organization. The demand is evidenced by Hartford Financial Services Group's recent decision to expand its liability coverage for nonprofits (Business Wire, 2017). Although the FVP and D\&O insurance cannot protect an organization from a lawsuit, they are a means to protect and encourage individuals to serve as board members and executives given the high degree of responsibility.

\section{Federal Regulators}

Because nonprofits are corporations, the laws pertaining to their limits and purposes are decided by state legislative bodies. However, because they afforded exemption from federal taxes, the federal government plays an important regulatory role. Fremont-Smith (2004) describes the federal regulation of nonprofits that includes three components: (1) the U.S. Congress, that "determines the nature and scope of regulation"; (2) the Treasury Department, that prepares proposals for the "promulgation" of legislation along with the IRS (a branch of the Treasury) who administers the laws and regulations; and (3) the federal courts who "interpret the laws and regulations and determine their constitutionality" and "holds the ultimate power" (p. 377). Together, these entities work together to ensure that charitable organizations benefit society.

As a bureau of the Department of the Treasury, the IRS is directed by Title 26 of the U.S. Code in order to fulfill its mission of helping American taxpayers to "understand and meet their tax responsibilities and enforce the law with integrity and fairness to all 
(IRS, 2016a, p. 1). As such, it is a key player in the regulation of nonprofits as they are often the first to notice irregularities or are asked to look into specific cases of mismanagement. All tax exempt entities earning more than $\$ 50,000$ in annual revenues are required to annually report their activities through the Form 990 Return of Organization Exempt from Income Tax (IRS, 2016b). If the IRS flags inconsistencies or irregularities in the Form 990, they will investigate. Usually, the irregularities are simple reporting errors while other times, they are egregious omissions of fact. If the IRS finds that a tax exempt organization has breached their fiduciary duties and has just cause, it can impose fines, penalties, and revoke tax exempt status. If the IRS finds criminal or illegal activities, the case moves to the courts to decide. However, many cases are resolved before they go to trial.

\section{State Regulators}

Each state has their own system to regulate and enforce charitable corporations and depending on the resources available, the states will take action first. A recent study mapped the regulatory environment for charitable oversight in the United States. The study found that the attorney general was the "sole state-level regulator" for 27 U.S. jurisdictions while the remaining 24 were bifurcated-divided between the attorney general and another state agency ${ }^{2}$ (Dietz, et al, 2017). The attorney general is typically responsible for "ensuring the proper use of charitable funds" through regulations and enforcement authority (Fremont-Smith, 2004, p. 54). In California, the attorney general is responsible for charity regulation, enforcement, and compliance.

Because of the sheer number of tax exempt organizations, and the lack of resources, both the federal and state regulators are unable to investigate all reports of

\footnotetext{
${ }^{2}$ Jurisdictions include the 50 states and the District of Columbia
} 
mismanagement or wrongdoing. Furthermore, for the IRS and state regulators, charitable regulation is just a small part of their responsibilities, compared to other areas such as consumer protection and corporate negligence (Helge, 2009). Furthermore, there are hundreds of thousands of nonprofit organizations with revenues less than $\$ 50,000$ that the federal and state agencies have no way of knowing whether organizations are fulfilling their fiduciary duties or not. As such, it is difficult to know the extent of negligence and mismanagement in the nonprofit sector. Yet, despite the lack of resources, both the federal and state regulators want the same thing: the use of charitable assets to be used for charitable purposes.

Breach of duties. Although we do not know the full extent of mismanagement and negligence in the nonprofit sector, there are many examples that provide insight into the types of issues that nonprofit leaders should take note of. Gibleman and Gelman (2001) surveyed domestic and international print media for charity fraud cases of less than $\$ 100,000$ amongst nonprofit health and human services agencies from 1998 to 2000 . Their search found 10 instances that occurred in the United States, totaling more than \$347 million in theft, embezzlement, or mismanagement and in all cases, they discovered that, "the ultimate responsibility for the wrongdoing rested with the board" (p. 50). What is most telling about their study is their conclusion that although these cases were high profile and documented in the media, they were most likely not isolated events, but rather an emerging pattern in the sector (Gibleman \& Gelman, 2001).

There are other examples of breaches of the fiduciary duties found in legislative cases involving mismanagement of charitable organizations. One such case was Stern v. Lucy Webb Hayes National Training School for Deaconesses (a.k.a. Sibley Hospital) in 
1974 that revealed breaches in fiduciary duties by both the board and management. The Sibley Hospital case was a class action suit brought by the patients against the hospital alleging that finances were mismanaged and used to personally benefit the trustees. The case revealed that the board treasurer, Donald Ernst, had set up several investment accounts using hospital funds that he maintained exclusive control over. Although the board had between 25 and 30 trustees it seemed that most of the decisions were being made by Ernst and the hospital administrator, John Orem. The case was ultimately dismissed, but the trustees were held liable for mismanagement, self interest, and conflict of interest (Fishman, Schwartz, \& Mayer, 2015).

\section{Knowledge Results}

In terms of measuring knowledge, the study focuses on how familiar nonprofit leaders are with the fiduciary duties of care, loyalty, and obedience (self-reported) and an assessment of their actual knowledge. The questions used in the survey are presented followed by reliability, then results of nonprofit leader familiarity with fiduciary duties by role and by number of boards served in the past 15 years (board service), followed by actual fiduciary duty knowledge by role and by board service and finally, and finally a comparison of familiarity and actual knowledge by role.

\section{Self Reported Knowledge}

Survey questions. In order to assess knowledge of fiduciary responsibilities, respondents were given a brief description of each of the duties of care, loyalty, and obedience and were asked to rate their familiarity of each one using a 4-point Likert scale (Not at All Familiar, Slightly Familiar, Moderately Familiar, and Very Familiar). To get a sense of overall understanding of their fiduciary roles, respondents were asked two 
additional questions: 1) if they believe they have enough knowledge to carry out their responsibilities and; 2) if they understood the organization's mission. For these two questions, respondents were given a 4-point Likert scale (Disagree, Somewhat Disagree, Somewhat Agree, and Agree) for answer options.

Reliability. Reliability for the familiarity of the fiduciary duties of care, loyalty, and obedience scale that consisted of three items was performed. The scale was found to be very reliable $(\alpha=.82)$ with each item in the same direction. Most items appeared to be worthy of retention, resulting in a decrease in the alpha if deleted. Table 3.2 provides descriptive data for the fiduciary duties.

Table 3.2

Descriptive Data for Familiarity of Fiduciary Duties for All Roles

Fiduciary Duty

\begin{tabular}{lcccccc} 
& N & Mean & Median & Dev. & Min. & Max. \\
\hline Care & 184 & 3.8 & 4 & .545 & 1 & 4 \\
Loyalty & 183 & 3.8 & 4 & .487 & 1 & 4 \\
Obedience & 183 & 3.7 & 4 & .606 & 1 & 4 \\
\hline
\end{tabular}

\section{Results: Familiarity and Understanding by Role}

Respondents were asked questions about how familiar they are with the fiduciary duties of care, loyalty, and obedience, if they understood their organization's mission, and if they had enough knowledge to carry out their responsibilities. First, the results are presented by role then by board service for how familiar they are with the fiduciary duties, their understanding of their organization's mission, then if they have enough knowledge to carry out their responsibilities.

Figure 3.3 illustrates the means of how familiar nonprofit leaders are about the fiduciary duties of care, loyalty, and obedience by role. Descriptive data for the means for the fiduciary duties for board members is presented in Table 3.3 and for executives in 
Table 3.4. Board members are moderately or very familiar with the fiduciary duties of care $(N=104, M=3.7)$, loyalty $(N=103, M=3.8)$, and obedience $(N=103, M=3.6)$.

Similarly, executives are moderately or very familiar with the fiduciary duties of care $(\mathrm{N}$ $=82, M=3.9)$, loyalty $(\mathrm{N}=82, M=3.9)$, and obedience $(\mathrm{N}=82, M=3.9)$.

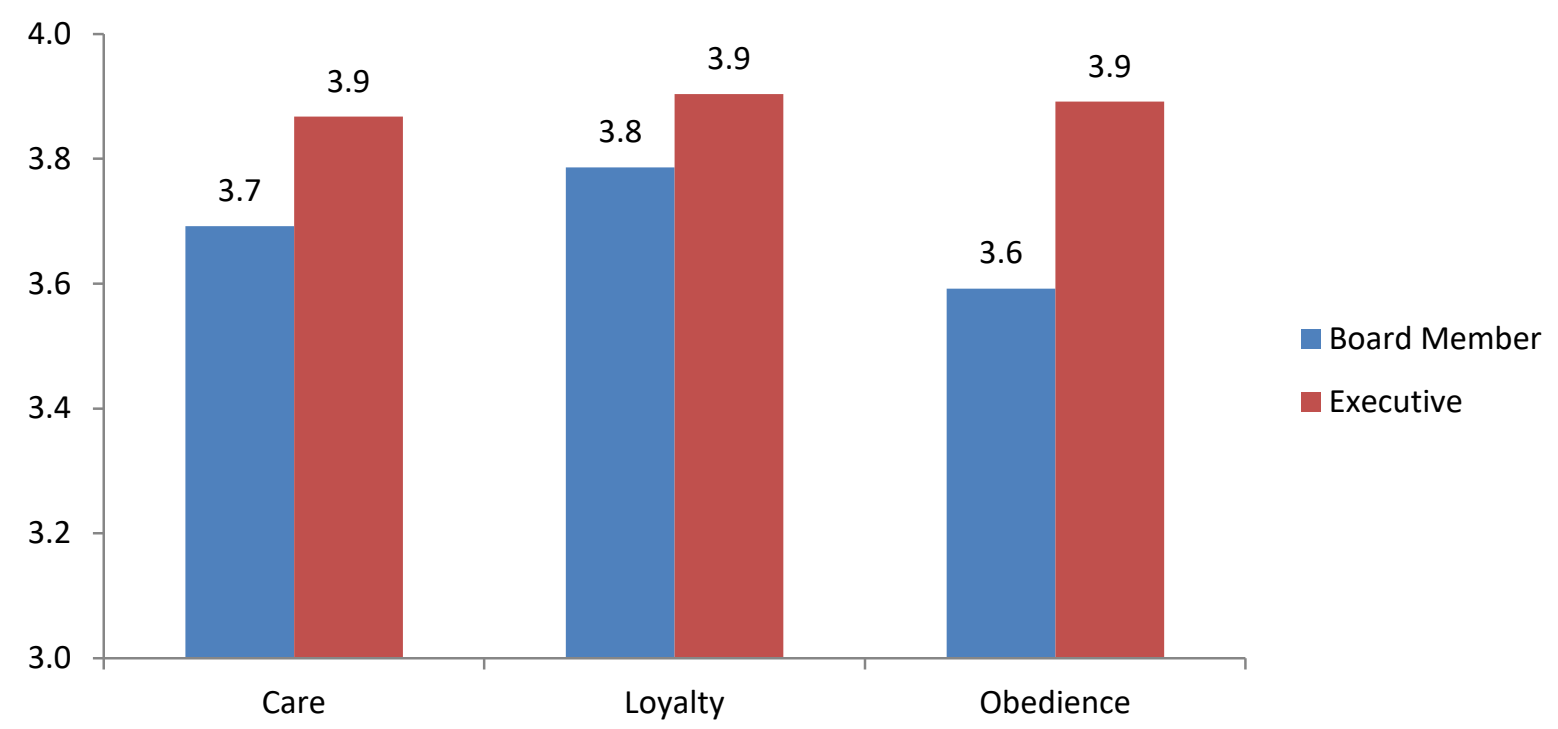

Figure 3.3. Means of nonprofit leader familiarity of fiduciary duties by role.

Table 3.3

Descriptive Data for Means of Familiarity of Fiduciary Duties for Board Members Fiduciary Duty

Std.

\begin{tabular}{lcccccc} 
& $\mathrm{N}$ & Mean & Median & Dev. & Min & Max \\
\hline Care & 104 & 3.7 & 4 & .655 & 1 & 4 \\
Loyalty & 103 & 3.8 & 4 & .536 & 1 & 4 \\
Obedience & 103 & 3.6 & 4 & .733 & 1 & 4 \\
\hline
\end{tabular}

Table 3.4

Descriptive Data for Means of Familiarity of Fiduciary Duties for Executives Fiduciary Duty Std.

\begin{tabular}{lcccccc} 
& $\mathrm{N}$ & Mean & Median & Dev. & Min & Max \\
\hline Care & 82 & 3.9 & 4 & .333 & 3 & 4 \\
Loyalty & 82 & 3.9 & 4 & .409 & 1 & 4 \\
Obedience & 82 & 3.9 & 4 & .318 & 3 & 4 \\
\hline
\end{tabular}

As presented in Table 3.5, board members somewhat agreed to agreed that they had enough knowledge to carry out their responsibilities $(N=95, M=3.6)$ and 
understood the organization's mission $(N=94, M=3.9)$. Similarly, executives somewhat agreed and agreed that they had enough knowledge to carry out their responsibilities $(N=$ $82, M=3.8)$ and agreed that they understood the organization's mission $(N=82, M=$ 3.9).

Table 3.5

Descriptive Data for Overall Understanding of Fiduciary Responsibilities by Board Members and Executives

\begin{tabular}{lcccccc}
\multicolumn{1}{c}{ Questions } & N & Mean & Median & $\begin{array}{c}\text { Std. } \\
\text { Dev. }\end{array}$ & Min & Max \\
\hline $\begin{array}{l}\text { "As a board member, I..." } \\
\text { Have enough knowledge to carry } \\
\text { out my responsibilities }\end{array}$ & 95 & 3.6 & 4 & .608 & 1 & 4 \\
$\begin{array}{l}\text { Understand the organization's } \\
\text { mission }\end{array}$ & 94 & 3.9 & 4 & .436 & 1 & 4 \\
$\begin{array}{l}\text { "As an executive, I..." } \\
\text { Have enough knowledge to carry }\end{array}$ & 82 & 3.8 & 4 & .404 & 2 & 4 \\
$\begin{array}{l}\text { Unt my responsibilities } \\
\text { mission }\end{array}$ & 82 & 3.9 & 4 & .191 & 3 & 4 \\
\hline
\end{tabular}

\section{Results: Familiarity and Understanding by Board Service}

Figure 3.4 presents the means of how familiar nonprofit leaders are about the fiduciary duties of care, loyalty, and obedience by board service. Nonprofit leaders who have served on one to four boards are moderately or very familiar with the fiduciary duties of care $(N=126, M=3.8)$, loyalty, $(N=126, M=3.8)$, and obedience $(N=126, M$ =3.7). Similarly, nonprofit leaders who have served on five or more boards are also moderately or very familiar with the fiduciary duties of care $(N=31, M=4.0)$, loyalty, $(N=31, M=4.0)$, and obedience $(N=31, M=3.9)$. Descriptive data for nonprofit leader means of fiduciary duties is presented in Table 3.6. 


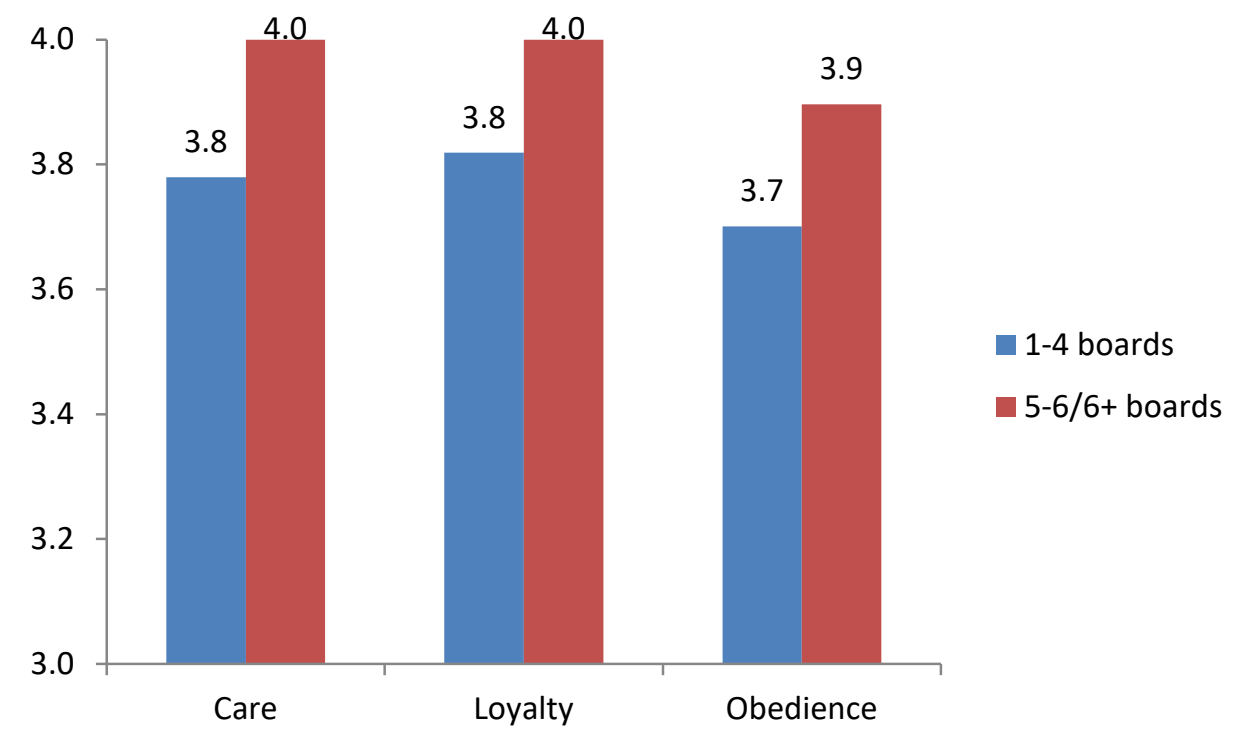

Figure 3.4. Means of nonprofit leader familiarity of fiduciary duties by board service. Note. The 1-2 board and 3-4 board categories were collapsed into a new category, 1-4 boards. The 5-6 board and 6+ board categories were collapsed into a new category, 5$6 / 6+$ boards.

Table 3.6

Descriptive Data of Nonprofit Leader Familiarity of Fiduciary Duties by Board Service

Std.

\begin{tabular}{lcccccc}
\multicolumn{1}{c}{ Fiduciary Duties of Care } & $\mathrm{N}$ & Mean & Median & Dev. & Min & Max \\
\hline 1-4 boards & 126 & 3.8 & 4 & .518 & 1 & 4 \\
5-6/6+ boards & 31 & 4 & 4 & 0 & 4 & 4
\end{tabular}

Fiduciary Duty of Loyalty

$1-4$ boards

$5-6 / 6+$ boards

$\begin{array}{cccccc}126 & 3.8 & 4 & .510 & 1 & 4 \\ 31 & 4 & 4 & 0 & 4 & 4\end{array}$

Fiduciary Duty of Obedience

$1-4$ boards 126

$31 \quad 3.9$

4

$4 \quad 3.897$

$3.897 \quad 3$

4

Note. The 1-2 board and 3-4 board categories were collapsed into a new category, 1-4 boards. The 5-6 board and $6+$ board categories were collapsed into a new category, 5$6 / 6+$ boards.

\section{Significance by Role}

Board members and executives are both legally responsible to uphold the fiduciary duties of care, loyalty, and obedience. This leads to the following hypothesis: 
$H_{1}$ : Board members and executives have the same familiarity about each of the fiduciary duties of care, loyalty, and obedience.

Table 3.7 presents the results of an independent $t$ test conducted for familiarity of the duty of care for board members $(N=104, M=3.7, S D=.599)$ and executives $(N=$ $82, M=3.9, S D=.343)$; for the duty of loyalty for board members $(N=104, M=3.8, S D$ $=.534)$ and executives $(N=82, M=3.9, S D=.416)$; and for the duty of obedience for board members $(N=104, M=3.6, S D=.731)$ and executives $(N=82, M=3.9, S D=$ .315) . There was a significant difference in board member and executive means for Care: $t(184)=16.570, p=.053$ and Obedience: $t(184)=51.302, p=.001$, but not for or Loyalty: $t(184)=7.321, p=.146$ (at the .05 significance level). Therefore, the hypothesis is not supported as there is significance between the means for board members and executives for the duties of care and obedience, but not for the duty of loyalty.

Table 3.7

Independent-sample t-Test Descriptive Data and Analysis for the Familiarity of Duties of Care, Loyalty, and Obedience by Role

\begin{tabular}{|c|c|c|c|c|c|c|c|c|c|}
\hline $\begin{array}{c}\text { Fiduciary } \\
\text { Duty }\end{array}$ & Role & $\mathrm{N}$ & Mean & $\begin{array}{l}\text { Std. } \\
\text { Dev. }\end{array}$ & $\mathrm{F}$ & $\mathrm{t}$ & df & $\mathrm{P}$ & $\begin{array}{l}\text { Sig. (2 } \\
\text { tailed) }\end{array}$ \\
\hline \multirow[t]{3}{*}{ Care } & & & & & 16.570 & -1.950 & 184 & .000 & .053 \\
\hline & $\begin{array}{l}\text { Board } \\
\text { Member }\end{array}$ & 104 & 3.7 & .599 & & & & & \\
\hline & Executive & 82 & 3.9 & .343 & & & & & \\
\hline \multirow[t]{3}{*}{ Loyalty } & & & & & 7.321 & -1.462 & 183.980 & .007 & .146 \\
\hline & $\begin{array}{l}\text { Board } \\
\text { Member }\end{array}$ & 103 & 3.8 & .534 & & & & & \\
\hline & Executive & 82 & 3.9 & .416 & & & & & \\
\hline \multirow[t]{3}{*}{ Obedience } & & & & & 51.302 & -3.402 & 184 & .000 & .001 \\
\hline & $\begin{array}{l}\text { Board } \\
\text { Member }\end{array}$ & 103 & 3.6 & .731 & & & & & \\
\hline & Executive & 82 & 3.9 & .315 & & & & & \\
\hline
\end{tabular}




\section{Significance by Board Service}

Regardless of the number of boards nonprofit leaders have served on, they are legally responsible to uphold the fiduciary duties of care, loyalty, and obedience. This leads to the following hypothesis:

$H_{1}$ : Nonprofit leaders have the same familiarity about each of the fiduciary duties of care, loyalty, and obedience regardless of the number of boards they have served on in the past 15 years.

As such an independent samples $t$ test was run to test for any significance between the nonprofit leaders who have served on four boards or less and those who have served on five or more boards. Table 3.8 presents the results for familiarity of the fiduciary duty of care for nonprofit leaders who have served one to four boards $(N=126, M=3.8, S D=$ $.515)$ and those who have served on five or more boards $(N=31, M=4, S D=.180)$; for the fiduciary duty of loyalty for nonprofit leaders who have served one to four boards ( $N$ $=126, M=3.8, S D=.512)$ and those who have served on five or more boards $(N=31, M$ $=4, S D=.180$ ); and for the fiduciary duty of obedience for nonprofit leaders who have served one to four boards $(N=126, M=3.7, S D=.648)$ and those who have served on five or more boards $(N=31, M=3.9, S D=.301)$. There was a significant difference in board service for Care: $t(155)=17.887, p=.055$, Loyalty: $t(155)=11.354, p=.110$, and Obedience: $t(155)=13.268, p=.089$ (at the .05 significance level). Therefore, the hypothesis is not supported as there is significance between the means for nonprofit leaders who have served on four boards or less and those who have served on five or more boards.

Table 3.8 
Independent-sample t-Test Descriptive Data and Analysis for the Familiarity of Duties of Care, Loyalty, and Obedience by Board Service

\begin{tabular}{llcccccccc}
$\begin{array}{l}\text { Fiduciary } \\
\text { Duty }\end{array}$ & \multicolumn{1}{c}{ Role } & $\mathrm{N}$ & Mean & $\begin{array}{c}\text { Std. } \\
\text { Dev. }\end{array}$ & F & t & df & P & Sig. \\
\hline Care & & & & & $\mathbf{1 7 . 8 8 7}$ & $\mathbf{- 1 . 9 3 3}$ & $\mathbf{1 5 5}$ & $\mathbf{. 0 0 0}$ & $\mathbf{. 0 5 5}$ \\
& 1-4 boards & 126 & 3.8 & .515 & & & & & \\
5-6/6+ boards & 31 & 4.0 & .180 & & & & & \\
Loyalty & & & & & $\mathbf{1 1 . 3 5 4}$ & $\mathbf{- 1 . 6 0 6}$ & $\mathbf{1 5 5}$ & $\mathbf{. 0 0 1}$ & $\mathbf{. 1 1 0}$ \\
& 1-4 boards & 126 & 3.8 & .512 & & & & & \\
5-6/6+ boards & 31 & 4.0 & .180 & & & & & \\
& & & & & $\mathbf{1 3 . 2 6 8}$ & $\mathbf{1 5 5}$ & $\mathbf{. 0 8 9}$ & $\mathbf{. 0 0 0}$ & $\mathbf{. 0 8 9}$ \\
& 1-4 boards & 126 & 3.7 & .648 & & & & & \\
& $5-6 / 6+$ boards & 31 & 3.9 & .301 & & & & & \\
\hline
\end{tabular}

Note. The 1-2 board and 3-4 board categories were collapsed into a new category - 1-4 boards. The 5-6 board and 6+ board categories were collapsed into a new category - 5$6 / 6+$ boards.

\section{Actual Knowledge}

As explained in the previous section, respondents were asked about their familiarity of the fiduciary duties of loyalty, care, and obedience. In this section, results are presented that illustrate what respondents actually know about their fiduciary responsibilities.

Survey questions. Respondents were given 19 questions in order to test their actual knowledge of fiduciary duties. Actual knowledge means demonstrating accurate knowledge by answering the questions correctly. Eight questions focused on items typically found in organizational bylaws and 11 questions were focused on specific aspects of each of the fiduciary duties. Of the 19 questions, eight questions were either not legal responsibilities or items typically included in bylaws to "test" respondents' ability to accurately answer. Respondents were given the option to answer "yes", "no", and "don't know" (for bylaws only). For each correct answer, respondents were given a 
"1" and for each incorrect answer, respondents were given a " 0 ". The highest possible score is 19 .

Respondents were asked eight questions about what items were included their organization's bylaws. The items included are those typically found in nonprofit bylaws with the exception of five that are not. The purpose of asking about bylaws was explore how many nonprofit leaders may have read their bylaws which is an aspect of fulfilling the fiduciary duty of obedience, knowing how the organization should conduct its decision making process. Next, respondents were to asked 11 questions related to legal responsibilities (required by federal and state law) of nonprofit boards and executives.

Three comprise the duty of care, three comprised the duty of loyalty, and one comprised the duty of obedience. Of the 11 questions, four of were not legal responsibilities. All questions are presented in Table 3.10.

By role. Table 3.9 presents the results of board members and executive actual knowledge of their fiduciary responsibilities. Actual knowledge is a combination of the 11 legal responsibilities and the eight bylaws questions for a total possible score of 19 . A $70 \%$ standard was applied to determine if respondents passed, since it is considered a passing grade (i.e. a "C") for most academic institutions. Overall, 54\% nonprofit leaders scored a passing grade $(N=186)$. For board members, $41 \%$ scored a passing grade $(N=$ 104) while $70 \%$ of the executives $(N=82)$ scored a passing grade.

Table 3.9

Descriptive Data for Passing Score of Actual Knowledge of Legal Responsibility by Role

\begin{tabular}{lccccccc} 
& $\mathrm{N}$ & $\begin{array}{c}\% \\
\text { Passed }\end{array}$ & Mean & Median & Dev. & Min & Max \\
\hline Board Members & 104 & $41 \%$ & 15.3 & 16 & 1.20 & 14 & 19 \\
Executives & 82 & $70 \%$ & 15.9 & 15.5 & 1.28 & 14 & 19 \\
All Roles & 186 & $54 \%$ & 15.6 & 15.5 & 1.28 & 14 & 19 \\
\hline
\end{tabular}

Note. Passing score based on $70 \%, 14$ out of 19 possible points. 
As presented in Table 3.10, when looking at specific aspects of fiduciary knowledge, the results show that nonprofit leaders have a range of actual knowledge. For example, in terms of legal duties, $82 \%$ of nonprofit leaders $(N=170)$ knew that frequently reviewing the organization's finances and financial policies was a legal responsibility; $97 \%(N=172)$ knew that disclosing conflict of interest was a legal responsibility; and 96\% $(N=171)$ knew that ensuring compliance with state and federal regulations was a legal responsibility. Conversely, only $30 \%(N=171)$ knew that reviewing board meeting materials prior to the board meeting was a legal responsibility and only $51 \%(N=171)$ knew that regular attendance of board meetings was a legal responsibility.

With regards to the bylaws questions, $99 \%$ of nonprofit leaders knew that board service positions, terms, and voting power $(N=164)$ were in the bylaws; $76 \%$ knew that executive staff roles and responsibilities were included in the bylaws $(N=159)$.

Conversely, only $46 \%(N=146)$ knew that financial accounting procedures were not in the bylaws and only $60 \%(N=156)$ knew that the board's expected financial commitment was not included in the bylaws. 
Table 3.10

Questions and Descriptive Data about Legal Responsibilities by All Roles

Questions

Duty of Care Responsibilities

1. Regular attendance of board meetings

2. Reviewing board meeting materials prior to the board meeting

3. Frequently reviewing organization's finances and financial policies

Duty of Loyalty Responsibilities

4. Disclosing potential conflicts of interest

5. Using independent judgment when making decisions about organizational resources

Duty of Obedience Responsibilities

6. Ensuring that individual board members, staff, or donors do not use organizational resources for personal reasons

7. Ensuring compliance with state and federal regulators Not a Legal Responsibility

8. Developing a strategic plan

9. Managing the day-to-day activities of the organization

10. Developing collaborations and partnerships with other organizations

11. Developing performance indicators for program effectiveness Bylaws Items

12. Board service positions, terms, and voting power

13. Board nomination and election process

14. Executive staff roles and responsibilities

Not Bylaw Items

15. Financial accounting procedures

16. Donor relations strategy

17. Organizational strategic plan

18. Board's expected financial commitment

19. Annual operating budget

Note. Percentage correct based on the number of respondents that correctly answered each question.

Table 3.11 presents the specific aspects of fiduciary knowledge results by role.

When analyzed by role, the results show that board members and executives vary in their actual knowledge. For board members and actual knowledge of their legal responsibilities, $80 \%(N=95)$ knew that frequently reviewing the organization's finances and financial policies was a legal responsibility; 95\% $(N=97)$ knew that disclosing conflict of interest was a legal responsibility; and $96 \%(N=96)$ knew that ensuring 
compliance with state and federal regulations was a legal responsibility. Conversely, only $34 \%(N=96)$ knew that reviewing board meeting materials prior to the board meeting was a legal responsibility and 50\% $(N=96)$ knew that regular attendance of board meetings was a legal responsibility.

With regards to the bylaws questions, $99 \%$ of board members $(N=91)$ knew that board service positions, terms, and voting power were in the bylaws; $97 \%$ knew that the board nomination and election process was included in the bylaws $(N=88)$. Conversely, only $38 \%(\mathrm{~N}=77)$ knew that financial accounting procedures were not in the bylaws and $52 \%(\mathrm{~N}=85)$ knew that the board's expected financial commitment was not included in the bylaws.

For executives and legal duties, $100 \%(N=75)$ knew that disclosing conflicts of interest was a legal responsibility and 99\% $(N=75)$ knew that ensuring that individual board members, staff, or donors do not use organizational resources for personal reasons was a legal responsibility. Conversely, only $25 \%(N=75)$ knew that reviewing board meeting materials prior to the board meeting was a legal responsibility and $53 \%(N=75)$ knew that regular attendance of board meetings was a legal responsibility.

With regards to the bylaws questions, $99 \%$ of executives $(N=73)$ knew that board service positions, terms, and voting power were in the bylaws; $90 \%$ knew that the board nomination and election process was included in the bylaws $(N=73)$. Conversely, only $55 \%(\mathrm{~N}=69)$ knew that financial accounting procedures were not in the bylaws and $70 \%(\mathrm{~N}=71)$ knew that the board's expected financial commitment was not included in the bylaws. 
Table 3.11

Questions and Descriptive Data about Legal Responsibilities by Role

\begin{tabular}{|c|c|c|c|c|c|}
\hline & Questions & $\begin{array}{l}\text { Board } \\
\mathrm{N}\end{array}$ & $\begin{array}{c}\text { Board } \\
\% \text { Correct }\end{array}$ & $\begin{array}{l}\text { Executive } \\
\mathrm{N}\end{array}$ & $\begin{array}{l}\text { Executive } \\
\% \text { Correct }\end{array}$ \\
\hline & Duty of Care Responsibilities & & & & \\
\hline 1 & Regular attendance of board meetings & 96 & $50 \%$ & 75 & $53 \%$ \\
\hline 2 & Reviewing board meeting materials prior to the & & & & \\
\hline & board meeting & 96 & $34 \%$ & 75 & $25 \%$ \\
\hline 3 & $\begin{array}{l}\text { Frequently reviewing organization's finances } \\
\text { and financial policies }\end{array}$ & 95 & $80 \%$ & 75 & $85 \%$ \\
\hline & Duty of Loyalty Responsibilities & & & & \\
\hline 4 & Disclosing potential conflicts of interest & 97 & $95 \%$ & 75 & $100 \%$ \\
\hline 5 & $\begin{array}{l}\text { Using independent judgment when making } \\
\text { decisions about organizational resources } \\
\text { Duty of Obedience Responsibilities }\end{array}$ & 97 & $65 \%$ & 75 & $64 \%$ \\
\hline 6 & $\begin{array}{l}\text { Ensuring that individual board members, staff, } \\
\text { or donors do not use organizational resources } \\
\text { for personal reasons }\end{array}$ & 97 & $90 \%$ & 75 & $99 \%$ \\
\hline 7 & $\begin{array}{l}\text { Ensuring compliance with state and federal } \\
\text { regulators }\end{array}$ & 96 & $96 \%$ & 75 & $97 \%$ \\
\hline & Not a Legal Responsibility & & & & \\
\hline 8 & Developing a strategic plan & 94 & $69 \%$ & 74 & $89 \%$ \\
\hline 9 & $\begin{array}{l}\text { Managing the day-to-day activities of the } \\
\text { organization }\end{array}$ & 96 & $79 \%$ & 74 & $97 \%$ \\
\hline 10 & $\begin{array}{l}\text { Developing collaborations and partnerships } \\
\text { with other organizations }\end{array}$ & 95 & $79 \%$ & 74 & $95 \%$ \\
\hline 11 & $\begin{array}{l}\text { Developing performance indicators for } \\
\text { program effectiveness }\end{array}$ & 91 & $75 \%$ & 73 & $82 \%$ \\
\hline 12 & $\begin{array}{l}\text { Board service positions, terms, and voting } \\
\text { power }\end{array}$ & 91 & $99 \%$ & 73 & $99 \%$ \\
\hline 13 & Board nomination and election process & 88 & $97 \%$ & 73 & $90 \%$ \\
\hline 14 & $\begin{array}{c}\text { Executive staff roles and responsibilities } \\
\text { Not Bylaw Items }\end{array}$ & 88 & $83 \%$ & 71 & $68 \%$ \\
\hline 15 & Financial accounting procedures & 77 & $38 \%$ & 69 & $55 \%$ \\
\hline 16 & Donor relations strategy & 68 & $78 \%$ & 70 & $87 \%$ \\
\hline 17 & Organizational strategic plan & 80 & $54 \%$ & 71 & $83 \%$ \\
\hline 18 & Board's expected financial commitment & 85 & $52 \%$ & 71 & $70 \%$ \\
\hline 19 & Annual operating budget & 84 & $58 \%$ & 73 & $81 \%$ \\
\hline
\end{tabular}

Note. Percentage correct based on the number of respondents that correctly answered each question. 
By board service. Table 3.12 presents the results of nonprofit leaders by board service actual knowledge of their fiduciary responsibilities. The actual knowledge is a combination of the 11 legal responsibilities and the eight bylaws questions for a total possible score of 19. A $70 \%$ standard was applied to determine if respondents passed, since it is considered a passing grade (i.e. a "C") for most academic institutions. When analyzed by board service, $56 \%$ of those who have served on one to four boards scored a passing grade $(\mathrm{N}=126)$ and $31 \%$ of those who have served on five or more boards scored a passing grade $(\mathrm{N}=31)$.

Table 3.12

Descriptive data for passing score of actual knowledge of legal responsibility by board service

\begin{tabular}{lccccccc} 
& $\mathrm{N}$ & $\begin{array}{c}\% \\
\text { Passed }\end{array}$ & Mean & Median & Dev. & Min & Max \\
\hline 1-4 Boards & 126 & $56 \%$ & 15.7 & 15.5 & 1.27 & 14 & 19 \\
5-6/6+ Boards & 31 & $31 \%$ & 15.5 & 15.5 & 1.34 & 14 & 19 \\
\hline
\end{tabular}

Note. Passing score based on $70 \%, 14$ out of 19 possible points. The 1-2 board and 3-4 board categories were collapsed into a new category - 1-4 boards. The 5-6 board and 6+ board categories were collapsed into a new category $-5-6 / 6+$ boards.

Table 3.13 presents the specific aspects of fiduciary knowledge results by board service. When analyzed by board service, the results show that actual knowledge of legal duties decreases the more boards that nonprofit leaders serve on. For example, in terms of legal duties, $53 \%$ of nonprofit leaders who have served on one to four boards $(N=125)$ knew that regularly attending board meetings was a legal requirement compared to $42 \%$ of those who served on more than five boards $(N=31)$. Ninety nine percent of those who served on one to four boards $(N=126)$ knew that disclosing potential conflicts of interest was a legal requirement compared to $87 \%$ of those who have served on five or more boards $(N=31)$. 
The opposite occurred in terms of knowing what items were not legal responsibilities. For example, $76 \%$ of the nonprofit leaders who served on one to four boards $(N=122)$ knew that developing a strategic plan was not a legal responsibility compared to $90 \%$ of those who served on five or more boards $(N=31)$ while $85 \%$ of nonprofit leaders who served on one to four boards $(N=123)$ knew that developing collaborations and partnerships with other organizations was not a legal responsibility compared to $97 \%$ of those who served on five or more boards $(\mathrm{N}=31)$. 
Table 3.13

Questions and Descriptive Data about Legal Responsibilities by Board Service

\begin{tabular}{|c|c|c|c|c|c|}
\hline & Questions & $\begin{array}{l}1-4 \\
\text { Boards } \\
\mathrm{N}\end{array}$ & $\begin{array}{c}1-4 \\
\text { Boards } \% \\
\text { Correct }\end{array}$ & $\begin{array}{l}5-6 / 6+ \\
\text { Boards } \\
\quad \mathrm{N}\end{array}$ & $\begin{array}{l}\text { 5-6/6+ } \\
\text { Boards } \\
\text { \% Correct }\end{array}$ \\
\hline & Duty of Care Responsibilities & & & & \\
\hline 1 & Regular attendance of board meetings & 125 & $53 \%$ & 31 & $42 \%$ \\
\hline 2 & $\begin{array}{l}\text { Reviewing board meeting materials prior to the } \\
\text { board meeting }\end{array}$ & 125 & $33 \%$ & 31 & $23 \%$ \\
\hline 3 & $\begin{array}{l}\text { Frequently reviewing organization's finances } \\
\text { and financial policies } \\
\text { Duty of Loyalty Responsibilities }\end{array}$ & 124 & $87 \%$ & 31 & $71 \%$ \\
\hline 4 & Disclosing potential conflicts of interest & 126 & $99 \%$ & 31 & $87 \%$ \\
\hline 5 & $\begin{array}{l}\text { Using independent judgment when making } \\
\text { decisions about organizational resources } \\
\text { Duty of Obedience Responsibilities }\end{array}$ & 126 & $68 \%$ & 31 & $55 \%$ \\
\hline 6 & $\begin{array}{l}\text { Ensuring that individual board members, staff, } \\
\text { or donors do not use organizational resources } \\
\text { for personal reasons }\end{array}$ & 126 & $94 \%$ & 31 & $87 \%$ \\
\hline 7 & $\begin{array}{l}\text { Ensuring compliance with state and federal } \\
\text { regulators } \\
\text { Not a Legal Responsibility }\end{array}$ & 125 & $97 \%$ & 31 & $97 \%$ \\
\hline 8 & Developing a strategic plan & 122 & $76 \%$ & 31 & $90 \%$ \\
\hline 9 & $\begin{array}{l}\text { Managing the day-to-day activities of the } \\
\text { organization }\end{array}$ & 124 & $86 \%$ & 31 & $94 \%$ \\
\hline 10 & $\begin{array}{l}\text { Developing collaborations and partnerships } \\
\text { with other organizations }\end{array}$ & 123 & $85 \%$ & 31 & $97 \%$ \\
\hline 11 & $\begin{array}{l}\text { Developing performance indicators for } \\
\text { program effectiveness } \\
\qquad \text { Bylaws Items }\end{array}$ & 119 & $77 \%$ & 30 & $87 \%$ \\
\hline 12 & $\begin{array}{l}\text { Board service positions, terms, and voting } \\
\text { power }\end{array}$ & 116 & $98 \%$ & 31 & $100 \%$ \\
\hline 13 & Board nomination and election process & 115 & $91 \%$ & 31 & $100 \%$ \\
\hline 14 & $\begin{array}{c}\text { Executive staff roles and responsibilities } \\
\text { Not Bylaw Items }\end{array}$ & 114 & $74 \%$ & 30 & $80 \%$ \\
\hline 15 & Financial accounting procedures & 104 & $45 \%$ & 31 & $45 \%$ \\
\hline 16 & Donor relations strategy & 96 & $85 \%$ & 30 & $83 \%$ \\
\hline 17 & Organizational strategic plan & 107 & $68 \%$ & 29 & $72 \%$ \\
\hline 18 & Board's expected financial commitment & 113 & $57 \%$ & 30 & $73 \%$ \\
\hline 19 & Annual operating budget & 111 & $71 \%$ & 31 & $65 \%$ \\
\hline
\end{tabular}

Note. The 1-2 board and 3-4 board categories were collapsed into a new category - 1-4 boards. The 5-6 board and 6+ board categories were collapsed into a new category - 5$6 / 6+$ boards. 


\section{Actual Knowledge of Each Duty}

By role. Table 3.14 presents and Figure 3.5 illustrate the results of nonprofit leaders with a passing score of actual knowledge of each of the duties of care, loyalty, and obedience by role. A passing score was given if they answered each question in each duty construct correctly (see Table 3.11 for list of questions in each construct by role). For board members, 59\% $(N=104)$ passed the duty of care, $25 \%(N=104)$ passed the duty of loyalty, and $90 \%(N=97)$ passed the duty of obedience. For the executives, $59 \%$ $(N=82)$ passed the duty of care, $18 \%(N=82)$ passed the duty of loyalty, and $99 \%(N=$ 75) passed the duty of obedience

Table 3.14

Percentage of Actual Knowledge of Fiduciary Duties by role

\begin{tabular}{lcc}
\multicolumn{1}{c}{ Role } & N & \% Passed \\
\hline \multicolumn{1}{c}{ Board Members } & & \\
Care & 104 & $59 \%$ \\
Loyalty & 104 & $25 \%$ \\
Obedience & 97 & $90 \%$
\end{tabular}

Executives

\begin{tabular}{lll} 
Care & 82 & $59 \%$ \\
Loyalty & 82 & $18 \%$ \\
Obedience & 75 & $99 \%$ \\
\hline
\end{tabular}

Note. Passing score based on answering each question in each construct correctly.

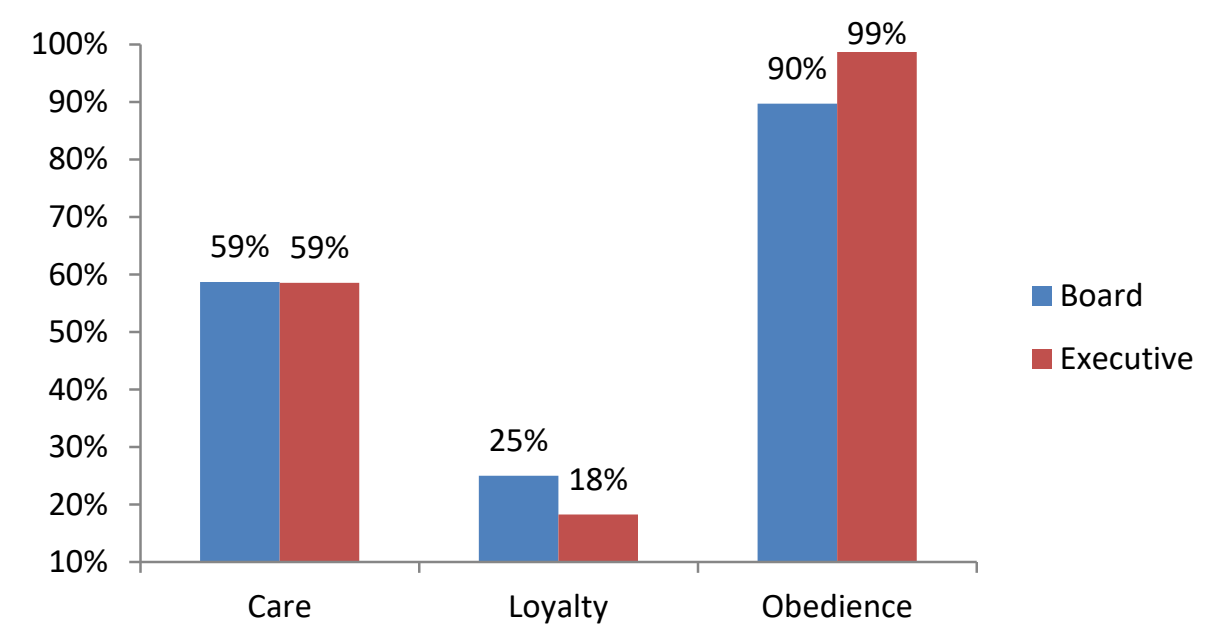

Figure 3.5. Percentage of nonprofit leader actual knowledge of fiduciary care, loyalty, and obedience by board service 
Board service. Table 3.15 presents and Figure 3.6 illustrates the results of nonprofit leaders with a passing score of actual knowledge of each of the duties of care, loyalty, and obedience by board service. A passing score was given if they answered each question in each duty construct correctly (see Table 3.13 for list of questions in each construct by board service). For nonprofit leaders who have served on one to four boards, $25 \%(N=126)$ passed the duty of care, $67 \%(N=126)$ passed the duty of loyalty, and $94 \%(N=126)$ passed the duty of obedience. For those who have served on five or more boards, $23 \%(N=31)$ passed the duty of care, $52 \%(N=31)$ passed the duty of loyalty, and $87 \%(N=31)$ passed the duty of obedience

Table 3.15

Percentage of Actual Knowledge of Fiduciary Duty by board service $\mathrm{N} \%$ Passed

\begin{tabular}{lcc}
\hline \multicolumn{1}{c}{$1-4$ boards } & & \\
Care & 126 & $25 \%$ \\
Loyalty & 126 & $67 \%$ \\
Obedience & 126 & $94 \%$ \\
$\quad$ 5-6/6+ boards & & \\
Care & 31 & $23 \%$ \\
Loyalty & 31 & $52 \%$ \\
Obedience & 31 & $87 \%$ \\
\hline Note Passing score based on answering each question in
\end{tabular}

Note. Passing score based on answering each question in each construct correctly.

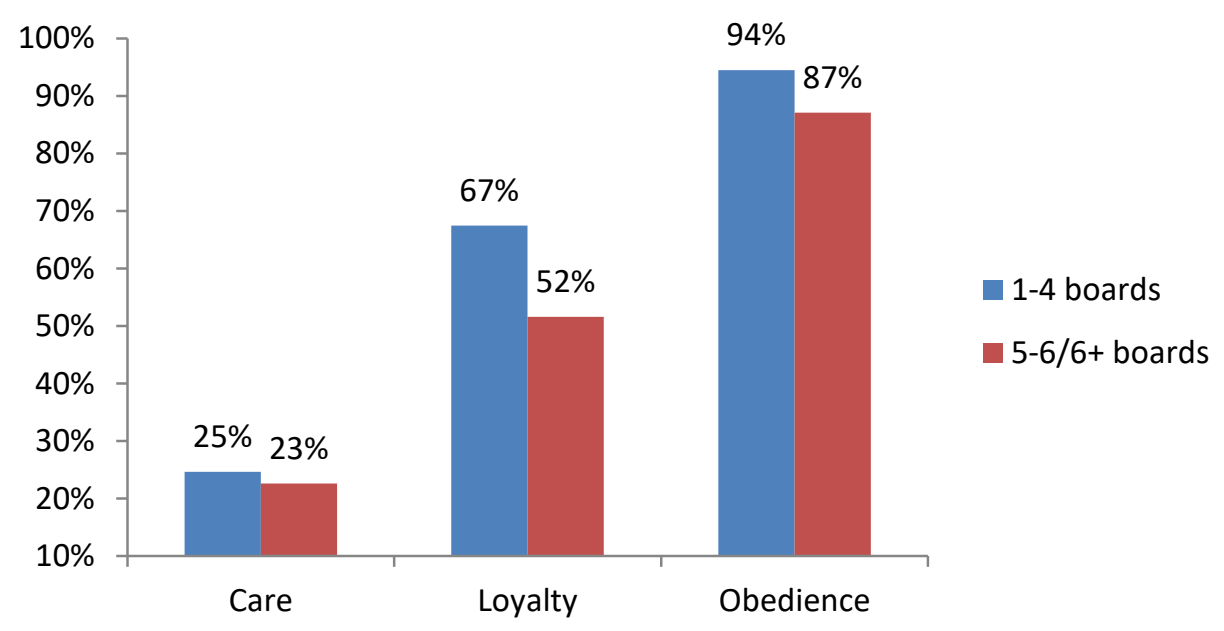

Figure 3.6. Percentage of nonprofit leader actual knowledge of fiduciary care, loyalty, and obedience by board service 


\section{Familiarity vs. Actual Knowledge}

Figure 3.7 illustrates presents the comparison of how familiar nonprofit leaders say they are with the fiduciary duties and their actual knowledge of specific aspects of the fiduciary duties for board members and Figure 3.8 illustrates the comparison of how familiar nonprofit leaders say they are with the fiduciary duties and their actual knowledge of specific aspects of the fiduciary duties for executives. Familiarity is presented by the means based on a 4-point Likert scale (Not at All Familiar, Slightly Familiar, Moderately Familiar, Very Familiar) and the actual knowledge score is based on the percentage who received a passing score of at least $70 \%$ for the 11 legal responsibilities and the eight bylaws questions. Overall, $41 \%$ of board members and $70 \%$ of the executives received a passing score for actual knowledge.

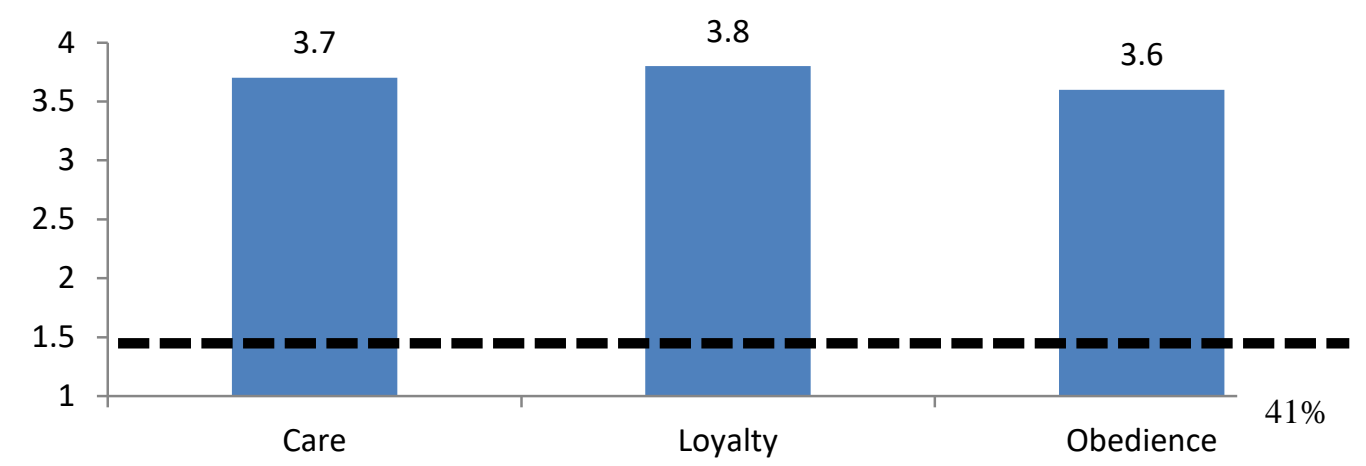

Figure 3.7. Means of familiarity of duty of care, loyalty, and obedience compared to the percentage of actual knowledge of overall fiduciary care, loyalty, and obedience for board members.

Note. The dotted line represents the percentage (41\%) of board members (care $N=104$, loyalty, $N=103$, and obedience, $N=97$ ) who received a passing score of $70 \%$ or better for the 19 questions about legal responsibilities and bylaws. Percentage for chart plotting was determined by calculating the proportion of $41 \%$ of 4 (the maximum mean score), which is 1.6 . 


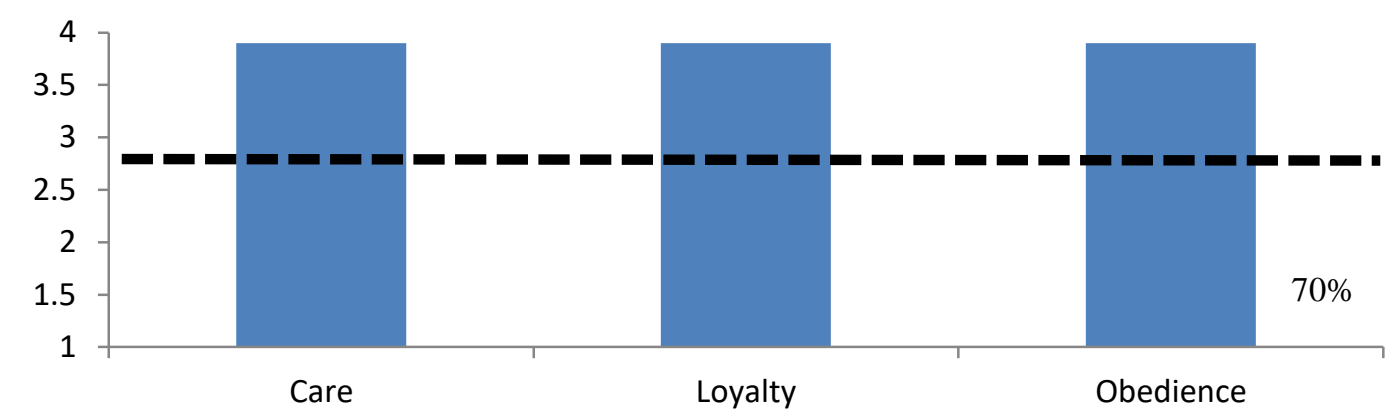

Figure 3.8. Means of familiarity of duty of care, loyalty, and obedience compared to the percentage of actual knowledge of overall fiduciary care, loyalty, and obedience for executives.

Note. The dotted line represents the overall percentage $(70 \%)$ of executives (care $N=82$, loyalty, $N=82$, and obedience, $N=75$ ) who received a passing score of $70 \%$ or better for the 19 questions about legal responsibilities and bylaws. Percentage for chart plotting was determined by calculating the proportion of $70 \%$ of 4 (the maximum mean score) which is 2.8 . 


\section{Discussion}

In this study, when nonprofit leaders were asked how familiar they were with the duties of care, loyalty, and obedience, the results indicate that they were moderately to very familiar. However, when they were tested for their actual knowledge of the legal responsibilities, only $41 \%$ of the board members and $70 \%$ of the executives received a passing score. What follows is a discussion about the gaps between familiarity and actual knowledge, first by the executives, then by the board members, and lastly by board service.

\section{The Gaps: Familiarity with Duties and Actual Knowledge}

\section{Executives}

In terms of understanding their organization's mission and having enough knowledge to carry out their responsibilities and overall familiarity with the duties of care $(M=3.9)$, loyalty $(M=3.9)$, and obedience $(M=3.9)$, executives responded with a great deal of familiarity. And, although it was expected that executives would be more familiar with the duties of care, loyalty, and obedience than board members, the hypothesis was partially supported for the duty of loyalty (even though it was found to not be statistically significant) and for the duty of obedience, but not for the duty of care. For the duty of care, the results for the executives and board members were the same $(M=3.9)$.

Duty of obedience. The duty of obedience focuses on compliance and ensuring that the mission is fulfilled. Because executives are in charge of the day-to-day management of the organization, these results are not surprising. Most executives are aware of, and often responsible for carrying out, annual reporting requirements such as the Form 990 annual tax return as well as work with the bookkeeper, auditor, and board 
to ensure items are submitted in a timely manner. Additionally, executives are intimately involved with the financial aspects of the organization and are responsible for providing information to the board. This explanation is supported by the specific legal responsibility results. Ninety nine percent of the executives knew that their legal responsibility was to ensure that staff, donors, and board members not use organizational resources for personal reasons while $97 \%$ of executives knew that compliance with state and federal regulators was a legal responsibility.

Bylaws. Bylaws are related to the duty of obedience in terms of compliance. Bylaws outline how the organization will conduct its business and once adopted, bylaws are legally binding. Nearly all of the executives correctly identified that board service positions, terms, and voting power (99\%) and board nomination and election processes (90\%) were included in their organization's bylaws. These results are not surprising, given that boards utilize bylaws particularly for the nomination process. Executives are usually asked to serve on the nominating committee to provide technical guidance to committee members. And, conversely executives may want to serve on the nominating committee to get a sense of who may be a potential board member, in other words, who their next boss might be.

Only $68 \%$ of the executives correctly identified that executive staff roles and responsibilities were included in the bylaws. This is surprising given that the bylaws outline overall authority of the executive related to signing contracts, finances, and bank access. For executives, it would be imperative to know how much formal authority they have and how their relationship with the board is legally defined. 
Duty of care. The duty of care focuses on paying attention and being engaged by making informed decisions. What is surprising with the results is the lack of actual knowledge that executives have about the legal responsibilities related to the duty of care. Only $53 \%$ of the executives correctly identified regular attendance of board meetings as a legal responsibility and only $25 \%$ correctly identified reviewing board meeting materials prior to the board meeting as a legal responsibility. These are relatively low percentage. However, $85 \%$ of the executives correctly identified frequently reviewing the organization's finances and financial policies as a legal responsibility. Although this number is greater than the other two, there is room for improvement.

It is not surprising to see that executives are more knowledgeable about their financial responsibilities given that more executives correctly identified reviewing financial materials as a legal responsibility. However, what is surprising is how little they understand the legal basis for board engagement. It would seem that if executives understood that regular attendance of board members in board meetings and reviewing materials prior to the board meeting were actual legal responsibilities, they may see increased board engagement. However, the gap is that the executives do not seem to understand themselves that these are legal responsibilities.

Duty of loyalty. The duty of loyalty focuses on conflict of interest and putting the interests of the organization above the interests of the individual. While it seems that all of the executives (100\%) correctly identified disclosing potential conflicts of interest as a legal responsibility, only $64 \%$ correctly identified the need to use independent judgment when making decisions about organizational resources as a legal responsibility. The conflict of interest results are not surprising, because conflict of interest is a widely 
discussed topic in the nonprofit sector and there are many practical tools available to address. However, what is surprising is the low percentage of executives who do not know that independent judgment is a legal responsibility. This may be explained by the executives' assumption that focusing more on conflict of interest deters board members putting their personal interest above the organization. Or, it may be explained by the nature of board service. Given that board members are volunteers, executives may have an assumption that board members have altruistic intentions for service. In either case, it is important for the executive to know that conflict of interest is a means to ensure that the duty of loyalty is fulfilled, however, board intentions, which are followed by actions, are also subject to legal standards.

\section{Board}

In terms of understanding their organization's mission and having enough knowledge to carry out their responsibilities and overall familiarity with the duties of care $(M=3.7)$, loyalty $(M=3.8)$, and obedience $(M=3.6)$, for the most part, board members were familiar. In terms of actual knowledge, overall $41 \%$ of the board members surveyed received a passing score for their actual knowledge of their legal responsibilities. The duty of obedience received the highest score (90\%), followed by the duty of care $(59 \%)$, then the duty of loyalty (25\%). To explore the gap between the familiarity with the fiduciary duties and actual knowledge, what follows are specific aspects of each of the duty of care, loyalty, and obedience constructs that are worth exploring.

Duty of obedience. The duty of obedience focuses on compliance and ensuring that the mission is fulfilled. Although the duty of obedience was the least familiar duty amongst board members, in terms of legal responsibilities, it was the most correct. Ninety 
percent of the board members knew that their legal responsibility was to ensure that staff, donors, and board members not use organizational resources for personal reasons while $96 \%$ of board members knew that compliance with state and federal regulators was a legal responsibility. A possible explanation for this is that board members know that they have to file tax returns, pay payroll taxes, and submit annual reports, but they may not understand these as actual legal responsibilities. Furthermore, they may not refer to these activities as related to the duty of obedience.

Bylaws. Bylaws are related to the duty of obedience in terms of compliance. Bylaws outline how the organization will conduct its business and once adopted, bylaws are legally binding. Nearly all of the board members correctly identified that board service positions, terms, and voting power (99\%) and board nomination and election processes $(97 \%)$ were included in their organization's bylaws. These results are not surprising, given that boards utilize nominating committees for board succession. The majority of nominating committees are made up of board members and it is common practice to refer to the bylaws to ensure that they are following the appropriate steps in nominating new board members.

Duty of care. The duty of care focuses on paying attention to the work and being engaged by making informed decisions. What is surprising with these results is the lack of actual knowledge that board members have about the legal responsibilities related to the duty of care. Only $50 \%$ correctly identified regular attendance of board meetings as a legal responsibility and only $34 \%$ correctly identified reviewing board meeting materials prior to the board meeting as a legal responsibility. These are relatively low percentages. However, $80 \%$ correctly identified frequently reviewing the organization's finances and 
financial policies as a legal responsibility. Although this number is greater than the other two, there is room for improvement.

It is not surprising to see that board members are more knowledgeable about their legal financial responsibilities given that financial reports are a primary agenda item at board meetings. However, what is surprising is how little they understand that attending board meetings is a legal responsibility, but that it is necessary in order to engage in the decision making process, another legal responsibility. When decisions cannot be made, because of a lack of quorum, the organization suffers. When the work of the organization suffers, board members can be found liable for a breach of their fiduciary duty of care and obedience.

Duty of loyalty. The duty of loyalty focuses on conflict of interest and putting the interests of the organization above the interests of the individual. While it seems that most of the board members $(95 \%)$ correctly identified disclosing potential conflicts of interest as a legal responsibility, only $65 \%$ correctly identified the need to use independent judgment when making decisions about organizational resources as a legal responsibility. The conflict of interest results are not surprising, because conflict of interest is a widely discussed topic in the nonprofit sector and there are many practical tools available to address. However, what is surprising is the low percentage of board members who do not know that independent judgment is a legal responsibility. This might be explained by the assumption that board members have the best interests of the organization as a priority, but may lack the awareness that this is based in their legal responsibilities. Or, it may be explained by the executive's role of informing the board 
and making recommendations about organizational direction resulting in reliance on, and deference to, the executive.

\section{By Board Service}

Overall, nonprofit leaders who have served on one to four boards had a high degree of familiarity with the duty of care $(M=3.8)$, loyalty $(M=3.8)$, and obedience $(M$ =3.7). Similarly, nonprofit leaders who have served on five or more boards also had a high degree of familiarity of the duty of care $(M=4.0)$, loyalty $(M=4.0)$, and obedience $(M=3.9)$, partially supporting the hypothesis that familiarity with fiduciary duties increases as board service increases based on the differences between the means of the familiarity of the duty of obedience between nonprofit leaders who serve on more boards as statistically significant.

However, for nonprofit leaders who have served on one to four boards, $25 \%$ received a passing score for their actual knowledge of the duty of care, $67 \%$ for duty of loyalty, and $94 \%$ for the duty of obedience. For those who have served on five or more boards, $23 \%$ received a passing score for the duty of care, $52 \%$ for the duty of loyalty, and $87 \%$ for the duty of obedience. To explore the gap between the familiarity with the fiduciary duties and actual knowledge, what follows are specific aspects of each of the duty of care, loyalty, and obedience constructs that are worth exploring.

Duty of obedience. The duty of obedience focuses on compliance and ensuring that the mission is fulfilled. The results show that as board service increases, actual knowledge decreases. This is supported by the results of nonprofit leader actual knowledge of legal responsibilities when analyzed by board service. For nonprofit leaders who have served on one to four boards, $94 \%$ correctly identified that not using 
organizational resources for personal benefit was a legal responsibility compared to those who have served on five or more boards $(87 \%)$. Yet when ensuring compliance with state and federal regulations, the percentages of nonprofit leaders who correctly identified ensuring compliance with state and federal regulations was legal responsibility was the same, regardless of board service (97\%). This is a curious result because it is assumed that an increase in board service, translates into an increase of knowledge. However, what may be happening is that nonprofit leaders may be concurrently serving on multiple boards, thus diluting their ability to absorb new knowledge. A 2016 study of 2,300 U.S. nonprofit board members revealed that for those who sit on more than one board, on average, they serve on four additional boards (Russell Reynolds Associates, 2016).

Bylaws. Bylaws are related to the duty of obedience in terms of compliance. Bylaws outline how the organization will conduct its business and once adopted, bylaws are legally binding. There were slight increases in actual knowledge as board service increased. Nonprofit leaders who have served on one to four boards correctly identified that board service positions, terms, and voting power (98\%); board nomination and election processes (91\%); and executive staff roles and responsibilities (74\%) were included in their organization's bylaws. Compared to the nonprofit leaders who have served on five or more boards $100 \%$ correctly identified that board service positions, terms, and voting power; $100 \%$ correctly identified board nomination and election processes; and $80 \%$ correctly identified that executive staff roles and responsibilities were included in their organization's bylaws. These results are not surprising based on the possible explanations described previously. 
Duty of care. The duty of care focuses on paying attention to the work and being engaged by making informed decisions. What is surprising with these results is the decrease in actual knowledge as board service increases. For nonprofit leaders who have served on one to four boards, $53 \%$ correctly identified regular attendance of board meetings as a legal responsibility compared to $42 \%$ of those who have served on five or more boards. Thirty three percent of nonprofit leaders who served on one to four boards correctly identified reviewing board meeting materials prior to the board meeting as a legal responsibility compared to $23 \%$ of those who have served on five or more boards. It is difficult to explain these results, because it is expected that more board service would translate into greater understanding of legal responsibilities. However, if nonprofit leaders are not given the opportunity to fully understand their responsibilities they bring their lack of knowledge with them to other boards they serve on.

Duty of loyalty. The duty of loyalty focuses on conflict of interest and putting the interests of the organization above the interests of the individual. Again, when analyzed by board service, we see a decrease in knowledge as board service increases. For nonprofit leaders who have served on one to four boards $99 \%$ correctly identified disclosing potential conflicts of interest as a legal responsibility compared to $87 \%$ of those who have served on five or more boards. And, $68 \%$ of the nonprofit leaders who have served on one to four boards correctly identified the need to use independent judgment when making decisions about organizational resources as a legal responsibility compared to $55 \%$ of those who have served on five or more boards.

The conflict of interest results are surprising, because on the one hand, conflict of interest is a widely discussed topic in the nonprofit sector and there are many practical 
tools available to address. And, on the other we would expect this percentage to be similar for those who have more board service, not decrease. Again, the decrease in knowing that independent judgment is a legal responsibility as board service increases is perplexing. More research is needed to better explore this area.

\section{Implications}

This study highlights the need for greater awareness of fiduciary responsibility knowledge and competence amongst nonprofit leaders. Overall, nonprofit leaders can use the results of this study to identify areas where greater awareness and knowledge is needed to support governance. Specifically the duty of care is an area that both executives and board members need to understand better. Showing up to meetings is the first step in fulfilling the legal responsibilities as a board member and executive. However, based on the results, many board members and executives do not understand that this is a legal responsibility and as such, most likely do not make attendance a priority. As board members attend meetings, they become more engaged in their oversight role and better informed about the organization's needs. Greater engagement strengthens their governance function and by default will meet legal accountability in fulfillment of the organization's mission.

The results of this study can also impact legislators and regulators. Given that legislators outline the expectations of nonprofit governance, they can use the results to understand gaps in what is expected and what is enforced. Because the fiduciary duties of care, loyalty, and obedience are expectations for all nonprofit leaders, regardless of organizational size, purpose, or location, they can be used as a basis to develop a standardized process that assesses a nonprofit leader's readiness for service. In turn, the 
assessment can be used during the orientation process to ensure that their board is made up of leaders that know their legal responsibilities. Furthermore, an assessment would help organizations use their resources to address specific gaps to deter mismanagement and wrong doing, whether negligent or willful.

Finally, the results of this study can impact those who consult with and provide professional services to nonprofits such as lawyers. Consultants are often hired to help with technical and systemic issues that nonprofits face. For governance issues, consultants can use the results of this study to support their recommendations as based on legal responsibilities for legitimacy. Furthermore, lawyers who may provide legal counsel can use the results of this study to address the basic legal responsibilities in a manner that nonprofit leaders can understand.

\section{Future Research}

This chapter reveals a gap between self reported and actual knowledge amongst nonprofit leaders both by role and board service. While this study is exploratory, in that it pilots an assessment tool and seeks to establish baseline data for future research, it highlights the need for greater awareness of fiduciary responsibility knowledge and competence. Additional empirical use of the assessment tool developed for this study will add not only to the nonprofit literature but also to the nonprofit law literature.

Additionally, future qualitative research may help to uncover the underlying reasons why the level of knowledge varies amongst board members and executives and by board service. 


\section{CHAPTER 4: SOURCE OF FIDUCIARY DUTY KNOWLEDGE}

Nonprofit regulations hold nonprofit leaders responsible for the oversight of tax exempt organization resources. However, apart from these guidelines, there are no standardized systems to determine if leaders have the appropriate knowledge nor to assess whether the source of their knowledge is credible. Therefore, it is not surprising that many board members and executives lack the appropriate knowledge about their fiduciary responsibilities (see chapter three). The broader purpose of this study is to establish baseline data about nonprofit leader knowledge of their fiduciary responsibilities, sources of knowledge, and application of knowledge in the performance of their fiduciary responsibilities. The purpose of this chapter is to inductively establish what internal and external sources (or best practices) nonprofit leaders (board members and executives) access to learn about their fiduciary responsibilities. The results provide key insights into how to address the knowledge gap.

\section{How Nonprofit Leaders Learn About Their Fiduciary Duties}

Nonprofits utilize many of the widely-accepted industry standard best practices to learn about their fiduciary responsibilities including accounting, marketing, program delivery, and fundraising resources and tools. For example, accounting best practices support financial management while fundraising best practices provide guidance about how to build a donor base. Yet, with the numerous standards available, what this study reveals is that nonprofit leaders prefer to access informal, socialized learning opportunities more than other formalized sources.

With regards to internal sources that are provided by their own nonprofit organizations, the sources nonprofit leaders utilize most, in order to learn about their 
fiduciary responsibilities, are informal conversations with board members and staff rather than formal board trainings, educational opportunities, or a board manual. The high reliance on informal sources of learning is the same when analyzed by role and board service. With regards to external sources nonprofit leaders access to learn about their fiduciary responsibilities, the findings show some differences between board members and executives in the type of external resources that are utilized. When analyzed by role, board members tend to utilize webinars, websites, print media and academic and certification programs more than executives. However, when analyzed by board service, there is a slight increase in reliance on websites for nonprofit leaders who have served on six or more boards in the past 15 years. These results contribute to the development of nonprofit leader trainings that suggest a more interactive, personable approach may be what is needed in order to ensure that nonprofit leaders have the necessary knowledge to fulfill their fiduciary duties.

In chapter three, results were presented about nonprofit leader knowledge of their fiduciary duties of care, loyalty, and obedience as a means to meet legal accountability for what. What the results revealed is that nonprofit leaders think they know more than they actually do. After comparing how familiar board members reported they were with the fiduciary duties of care, loyalty, and obedience, only $41 \%$ of the respondents received a passing grade of "C" or better compared to executives at $70 \%$. This chapter builds on chapter three by focusing on the source of knowledge as a means to satisfy legal accountability how as illustrated in Figure 4.1. 


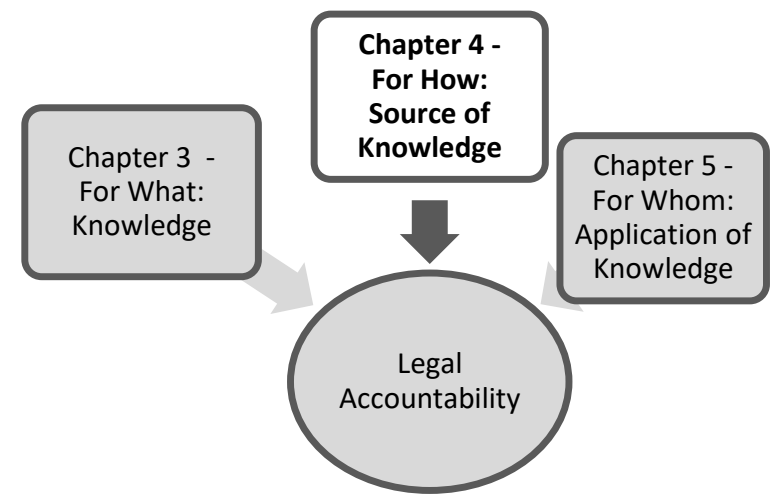

Figure 4.1. Framework for Legal Accountability.

Additionally, this chapter focuses on the second level of Miller's model of knowledge assessment (1990), the "knows how" level, and the second construct of this study-the types of sources nonprofit leaders access in order to learn about their responsibilities, as illustrated in Figure 4.2.

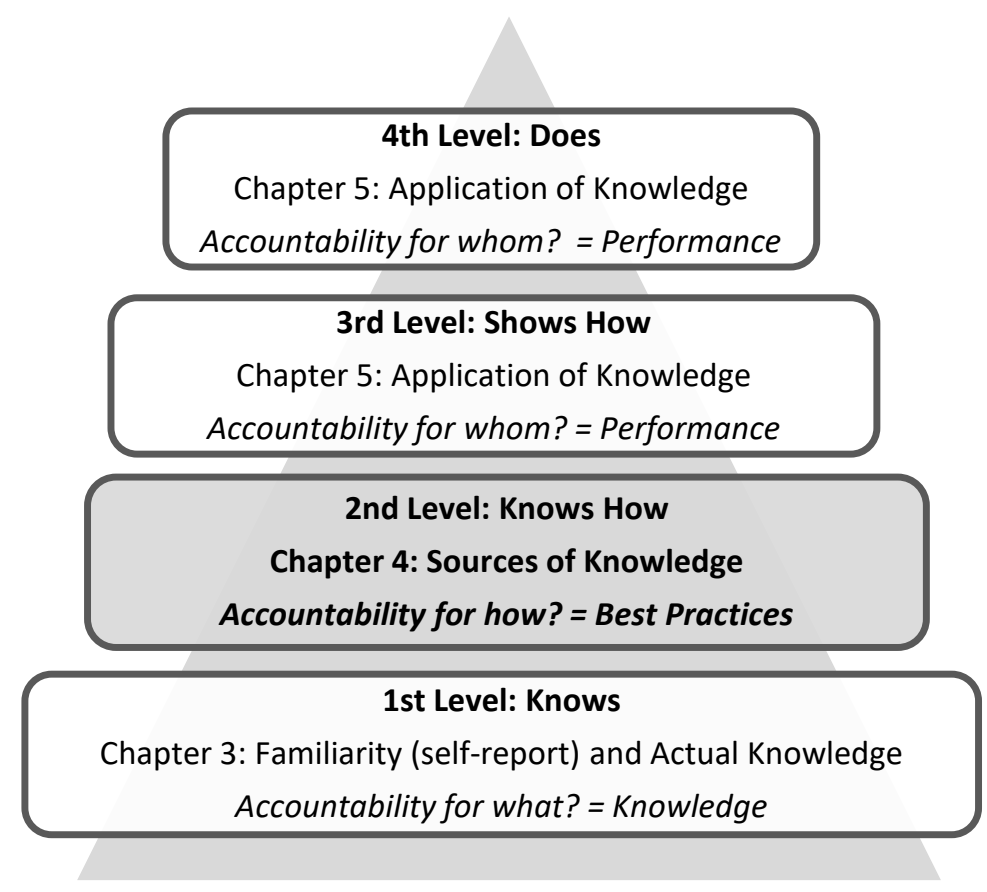

Figure 4.2. Constructs and Legal Accountability. 
Following is a discussion about the external dynamics, pressures, and demands that nonprofit leaders face by applying theoretical framework of institutionalism and isomorphism with some focus on effectiveness and performance. Next, is the idea of best practices as widely accepted sources that nonprofit leaders access to learn about their fiduciary responsibilities. After discussing best practices, the results of the types of sources, both internal and external to the organization that nonprofit leaders use to learn about their fiduciary roles are presented. Finally, the chapter concludes with a discussion about the results and future research.

\section{External Dynamics, Demands, and Pressures}

Theories of the nonprofit sector identify external dynamics that compel nonprofit leaders to demonstrate legal accountability that include funders, governments, and the public.

\section{Institutionalism}

Looking at nonprofit governance through an institutionalist lens provides insight into how nonprofit leaders behave. For clarification, the theory allows for a broad definition of institutions that includes any entity that has been formally created, either socially constructed or legally formed, that has a certain degree of legitimacy. For the purposes of this study, I am focusing on nonprofit organizations as an institution and more specifically, nonprofit leaders (board members and executives) within nonprofit organizations.

Institutionalism emerged as an alternative to rational theories that focused on technical aspects of organizations (Meyer \& Rowan, 1977). By the mid-20 ${ }^{\text {th }}$ century, it became a popular framework for political scientists and sociologists as a means to 
understand the changing environments that organizations were faced with by focusing on how organizations respond to their environments for legitimacy (DiMaggio \& Powell, 1983; Scott, 2008). A variation of institutionalism, neoinstitutionalism, gained traction as more attention was given to decision-making, practices, and structures that institutions adopted for legitimacy (Scott, 2008). Today, many contemporary scholars apply neoinstitutionalism and according to Jepperson, neoinstutionalism is "one of the most empirically developed forms of institutional analysis" (as cited in Berger \& Zelditch, 2002, p. 229).

Institutionalism posits that institutions are diverse social structures that operate within, and are influenced by, three connected, yet separate, "pillars", regulative, normative, and cultural-cognitive (Scott, 2008). The regulative pillar relates to legal standards and restrictions that institutions must pay attention to. The normative pillar underscores the role of values and norms that society expects institutions to operate within. Finally, the cultural-cognitive pillar focuses on the socially constructed meaning that institutions provide. Together, these pillars provide a framework that helps us understand how institutions contribute to a sense of meaning and purpose to society and in return institutions gain legitimacy.

For the purposes of this study, the focus is on the regulative pillar to align with legal accountability as DiMaggio and Powell (1983) offered that "the existence of a common legal environment affects many aspects of an organization's behavior and structure" (p. 150). Externally, tax exempt organizations are regulated by federal and state governments and are bound by requirements, that if not adhered to, could result in fines, penalties, and potentially tax revocation. 


\section{Institutional Isomorphism}

An example of a neoinstitutionalist approach comes from organizational and management scholars Paul DiMaggio and Walter Powell (1983). The pair identified the paradox of growth differentiation and moved away from institutionalism's focus on heterogeneity and added an isomorphic lens of similarity. They concluded that rather than trying to understand what makes organizations different, it is better to look at what makes them the same and what environmental factors contribute to their increased similarities (DiMaggio \& Powell, 1983). This aspect of institutionalism was coined institutional isomorphism, which has become a widely accepted framework with which to study nonprofits (Ashworth, et al., 2007; Frumkin \& Galaskiewicz, 2004; Verbruggen, et al., 2011).

Institutional isomorphism draws on classical institutionalism in that it focuses on how organizations respond to their environments in order to gain legitimacy. Coupled with the isomorphic element that identifies how organizational processes or structures increasingly converge, isomorphism explains that as organizations respond to external pressures, rules, norms, and sanctions they become more similar over time (Bromley \& Meyer, 2017; Miller-Millesen, 2003; Van Puyvelde, 2016). Therefore, nonprofit organizations behave in a manner that aligns with isomorphism when they adopt procedures, structures, and policies that are used by their colleagues, which provides a certain degree of legitimacy (Miller-Millesen, 2003).

Within isomorphism, DiMaggio and Powell (1983) discussed three specific distinct, yet interrelated, mechanisms that work together: coercive, mimetic, and normative. Similar to the regulatory pillar in institutionalism mentioned earlier, coercive 
isomorphism focuses on consequences and sanctions resulting from unmet expectations, real or perceived (Miller-Millesen, 2003). These expectations are particularly important when looking at how nonprofits address funding and legal pressures. Examples of nonprofits behaving in a coercive isomorphism manner are found when organizations give their large donors preferential treatment (e.g. VIP seating at events, exclusive recognition, a seat on the board, etc.) for fear of losing funding. Other examples of coercive isomorphism include organizations giving the public access to audited statements and tax returns on their websites to promote transparency. Another example of coercive isomorphism can be found in Miller-Millesen's (2003) example of local chapters or affiliates who are expected to behave according to their national charters and, if not adhered to, may result in the local chapter dissolving or bifurcating from the national entity thus losing legitimacy.

Mimetic isomorphism occurs when there is a level of uncertainty that an organization might not know how to face (DiMaggio \& Powell, 1983). This type of uncertainty could be related to market fluctuations, changing client needs, or the loss of resources (financial, physical, human, or intellectual). When uncertainty occurs, organizations look to other organizations that they perceive are more successful and adopt similar processes, policies, and structures as their own (DiMaggio \& Powell, 1983; Miller-Millesen, 2003). Although this may seem like a perfectly good approach, the problem is that often organizations are reactive in the face of uncertainty and adopt practices and policies without regard as to how relevant or useful they might be for their own particular organization. This is an example of decoupling; when the adaptations 
contradict internal efficiency needs to gain legitimacy, which will be discussed in more detail later in the results section (Boxenbaum \& Jonsson, 2017).

I have seen decoupling in action as a nonprofit consultant, particularly in my work with boards. One particular example comes to mind when I was working with an animal rescue organization who was applying for tax exempt status. When we discussed how their programs would operate, they insisted on implementing an identical program that another animal rescue organization was offering, because they thought that it would generate the same type of funding. What they failed to consider was how different their organization was and how to develop a program that suited their situation. Even after I encouraged them to take the time necessary to ensure a successful program, they chose to move forward with their original plan. This is similar to Zucker's conclusion that "actions are taken in a specific way just because they have become an accepted way of accomplishing them" (as cited in Miller-Millesen, 2003, p. 536), which resonates with mimetic isomorphism behavior.

Normative isomorphism typically occurs when there is the need for professionalism (DiMaggio \& Powell, 1983; Miller-Millesen, 2003). An example of normative isomorphism pressures can be found in the growth of the nonprofit academic programs over the past few decades (Carpenter, 2011; Mirabella, 2007). The need for professionalization, fueled by donor demands for transparency and accountability in the face of scandals and misappropriations, and the overall increased demands for programs and services, has warranted the need for skilled leaders and staff. 


\section{The Role of Best Practices}

In building on the previous discussion of the external dynamics, demands, and pressures that impact legitimacy, I offer that isomorphism helps to explain how best practices support nonprofit leader accountability by understanding their fiduciary roles and responsibilities. Holland (2002) sums up the tension of accountability by suggesting that the literature's definitions of accountability overlap and the issue is not just about how to define it, but also how to uphold or meet. Because of the lack of a standardized system that assesses organizational effectiveness, accountability, or performance not much is known about the inner-workings of nonprofit governance. As such, Ebrahim (2010) offers that in a mechanism nonprofits use to meet the accountability demands is self-regulation — or best practices since best practices tend to be practitioner or industrybased in that they are developed to meet the immediate, practical needs of an organization.

Examples of best practices can be found in for profit and nonprofit literature as a means to support performance, accountability, and effectiveness (Ebrahim, 2010; O'dell \& Grayson, 1998). Herman and Renz (2000) offered that the "prescriptive literature suggests that boards using a greater number of recommended board practices will be more effective" (p. 156). However, Ebrahim (in Renz, 2010) offered that although there has been an increase in industry-wide standards developed over the past few decades, there is limited empirical evidence that they actually work.

The term best practice is commonplace in the nonprofit sector. As a means to help leaders and organizations meet the expectations of the wide variety of stakeholders from governments, funders, and the public, best practices are in ample supply. Nationally 
recognized organizations including BoardSource, GuideStar, and Foundation Center along with state attorney generals, the IRS, and national nonprofit associations have all developed best practices for a myriad of organizational uses. Examples of best practices can be seen in all aspects of nonprofit management. Financial best practices can be seen in the use of policies and procedures that support efficient accounting such as balance sheets, cash flow statements, and profit and loss statements. Commonly used fundraising best practices are gift acceptance policies and capital campaigns. Other operational areas such as marketing, technology, program service delivery, and human resource management also have a variety of best practices that organizations utilize. Herman and Renz (2008) referred to Keehley, Medlin, Longmire, and McBride's seven criteria to determine if an approach or process is a best practice. The criteria includes, "be successful over time, show quantifiable gains, be innovative, be recognized for positive results, be replicable, have relevance to the adopting organization and not be linked to unique organizational characteristics" (p. 405), however, Herman and Renz (2008) note that they had not found any best practices that remotely meets this criteria.

Holland's (2002) observation of how best practices are created resonates with Herman and Renz (2000; 2008) who discussed the nuances related to studying nonprofit organizations. Because of the myriad of theoretical frameworks applied to nonprofits, Herman and Renz $(2000 ; 2008)$ offered that the most useful way to look at nonprofits is through a social constructionist lens, which is used in institutionalism and isomorphism. Using this perspective, social constructivism may explain how best practices are the means by which organizations satisfy legal accountability how. The social constructivist perspective offers that discovery is less about finding what works and more about 
inventing something that works (Herman \& Renz, 2000). Therefore, best practices are socially constructed tools and guidelines developed by nonprofit practitioners, academics, and regulators as a means to support legal accountability and gain legitimacy.

However, a social constructivist lens of best practices poses a dilemma. On the one hand, Miller (2002) concludes that, despite the differences amongst nonprofit boards, there is a widely accepted set of best practices that when used, "converge on a set of board roles and responsibilities characteristic of good governance" (p. 430). On the other side, because of a wide range of best practices available, for example in governance, Holland (2002) offered that the lack of standardized measures makes it difficult to determine if a board is effective (i.e. legitimate) in their oversight role because the impact is hard to measure. To address this dilemma and in support of the neoinstitutionalist perspective, Bromley and Meyer (2017) suggested that what allows common practices to become standardized is that they are based in the society's norms—or "codes of conduct" (p. 946). These codes are ingrained in the cultural model that focuses more on the public good rather than in production efficiencies or formalized expectations by external actors (Bromley \& Meyer, 2017). As such, best practices have become socially constructed proxies in lieu of standardized assessments in the nonprofit sector.

\section{Accessing Knowledge to Meet Demands and Pressures}

Coercive, mimetic, or normative isomorphic pressures were not measured in this study. Rather, institutionalism and isomorphism is used as a framework where coercive, mimetic, and normative pressures coalesce in explaining how nonprofit leaders accessing sources of fiduciary knowledge is a means to gain legitimacy, particularly when meeting legal accountability. What is being measured, however, are the types of sources that 
nonprofit leaders access when learning about their fiduciary responsibilities and how the sources may be coercive, mimetic, normative, or a combination of all three.

\section{Sources of Fiduciary Knowledge - Results}

In looking at external demands for legitimacy and to satisfy legal accountability, the use of best practices is useful. For nonprofit leaders, governance best practices focus on all aspects of organizational oversight including fiduciary responsibilities. Nonprofit leaders were asked which best practices they accessed in order to learn about their responsibilities, specifically internal and external sources as presented in Table 4.1.

Typically, nonprofit leaders have access to a wide variety of opportunities both at no cost and for a fee, in a variety of settings, for a variety of governance topics. The list of options in was developed after a review of practitioner, academic, and industry resources as well as from personal experience as a nonprofit executive and board member (Brown, 2007; Herman \& Renz, 2000; Independent Sector, 2017; Nonprofit Association of Oregon, 2016; Schwab Foundation for Social Enterprise, 2012). For example, Brown (2007) highlighted that one particular best practice, a board orientation, seemed to prepare leaders to address change and meet governance pressures. Informal conversations with colleagues as an internal best practice and externally with networks does not necessarily align with any of the isomorphic pressures, however it is included because of the basic premise that nonprofits are made up of people and people naturally engage with one another. 
Table 4.1

Internal and External Best Practices Resources

Internal Best Practices External Best

Practices

\begin{tabular}{ll}
\hline $\begin{array}{l}\text { Formally scheduled } \\
\text { board member } \\
\text { orientation }\end{array}$ & Websites/Webinars \\
$\begin{array}{l}\text { Informal conversations } \\
\text { with board members } \\
\text { and staff }\end{array}$ & $\begin{array}{l}\text { Magazines, Journals, } \\
\text { Books }\end{array}$ \\
$\begin{array}{l}\text { Educational } \\
\text { opportunities arranged } \\
\text { by the organization for } \\
\text { board members }\end{array}$ & $\begin{array}{l}\text { Friends and Family } \\
\text { Internal Best Practices }\end{array}$ \\
$\begin{array}{l}\text { External Best } \\
\text { Board Manual }\end{array}$ & $\begin{array}{l}\text { Practices } \\
\text { Certification/Degree } \\
\text { programs }\end{array}$ \\
\hline
\end{tabular}

\section{Internal Sources of Knowledge}

The following presents the results of the types of internal sources nonprofit leaders access in order to learn about their responsibilities. First, the results are presented by role then by board service.

By role. When asked about what internal sources nonprofit leaders used to help them learn about their roles and responsibilities, respondents were asked to check all that applied from the four options listed (see Table 4.1). The results, presented in Table 4.2, show that all of the resources were accessed, however, $79 \%$ of board members and $80 \%$ of the executives relied more on informal conversations than any other internal resource. Following informal conversations, board members $(N=104)$ accessed board manuals $(56 \%)$, educational opportunities (38\%), and orientations $(48 \%)$; while executives $(N=$ 82) accessed board manuals (48\%), orientations (42\%), and educational opportunities $(48 \%)$ 
Table 4.2

Descriptive Data for Percentages of Types of Internal Sources Nonprofit Leader Access by Role

Role N Orientation Informal Educational Board

\begin{tabular}{cccccc} 
& & Conversations & Opportunities & Manual \\
\hline Board Member & 104 & $48 \%$ & $79 \%$ & $38 \%$ & $56 \%$
\end{tabular}

$\begin{array}{llllll}\text { Executive } & 82 & 42 \% & 80 \% & 48 \% & 48 \%\end{array}$

Note. Categories were not mutually exclusive percentages were calculated by dividing the number of responses for each option by the total number of responses for each role.

By board service. The results are similar when analyzed for board service as shown in Table 4.3. Regardless of the number of boards served on in the past 15 years informal conversations is the source of knowledge most accessed for each category of board service (1-2 boards: $N=79,86 \% ; 3-4$ boards; $N=48,94 \% ; 5-6$ boards $N=16$, $100 \%$; and $6+$ boards $N=14,93 \%$ ). However, there are some differences worth noting. Nonprofit leaders who have served on six or more boards $(N=14)$ rely more on board orientations (79\%) and educational opportunities (64\%) than those who have served on fewer than six boards $(N=143)$. While those who have served on one to two boards $(N=$ 79 ) in the past 15 years tended to access the board manual more (59\%) than the board orientation (44\%). These results show that although informal conversations are relied on the most regardless of the number of boards served on, those who have served on six or more boards $(N=14)$ access more formal best practices (board orientation $=79 \%$; educational opportunities $=64 \%$; and board manual $=57 \%$ ) the most. 
Table 4.3

Descriptive Data for Percentages of Type of Internal Sources Nonprofit Leader Access by Number of Boards Served

\begin{tabular}{cccccc}
$\begin{array}{c}\text { Number of } \\
\text { Boards }\end{array}$ & N & Orientation & $\begin{array}{c}\text { Informal } \\
\text { Conversations }\end{array}$ & $\begin{array}{c}\text { Educational } \\
\text { Opportunities }\end{array}$ & $\begin{array}{c}\text { Board } \\
\text { Manual }\end{array}$ \\
\hline $1-2$ & 79 & $44 \%$ & $86 \%$ & $42 \%$ & $59 \%$ \\
$3-4$ & 48 & $58 \%$ & $94 \%$ & $56 \%$ & $63 \%$ \\
$5-6$ & 16 & $44 \%$ & $100 \%$ & $38 \%$ & $50 \%$ \\
$6+$ & 14 & $79 \%$ & $93 \%$ & $64 \%$ & $57 \%$ \\
\hline
\end{tabular}

Note. Categories were not mutually exclusive. Percentages were calculated by dividing the number of responses for each option by the total number of responses for number of boards served.

\section{External Sources of Knowledge}

The following presents the results of the types of external sources nonprofit leaders access in order to learn about their fiduciary responsibilities. First, the results are present by all roles and all boards served, then by role, and finally by board service (the number of boards served in the past 15 years).

As mentioned previously, for the internal source questions respondents were given the option to check that all apply. In hindsight, a multi-item scale for each internal source should have been used instead. For the external sources, a three-point Likert option (Never, Sometimes, and Always) was provided, which allowed Cronbach's alpha for reliability. The external source scale consisted of five items and was found to be moderately reliable $(\alpha=.65)$ with each item in the same direction. Most items appeared to be worthy of retention, resulting in a decrease in the alpha if deleted, except for two items: networks and academic/certificate programs. Deleting networks would increase the alpha to $\alpha=.722$ and deleting academic/certificate programs would decrease the alpha to $\alpha=.622$. Descriptive data for the Cronbach's alpha analysis is presented in Table 4.4 
Table 4.4

Descriptive Data for External Sources for Fiduciary Duty Knowledge for All Respondents

\begin{tabular}{lccccc} 
External Sources & $\mathrm{N}$ & Mean & Dev. & Min. & Max. \\
\hline Websites & 154 & 2.2 & 2 & .946 & 1 \\
Webinars & 154 & 1.7 & 2 & .800 & 1 \\
Print & 154 & 1.8 & 2 & .852 & 1 \\
Network & 154 & 1.8 & 2 & .852 & 1 \\
Programs & 154 & 1.6 & 2 & .891 & 1 \\
\hline
\end{tabular}

All roles and all board service. Table 4.5 presents the results by all roles and Table 4.6 presents the results by board service. Figure 4.3 illustrates that although all of the resources were accessed similarly, nonprofit leaders accessed websites the most regardless of role $(N=154, M=2.2, S D=.946)$ or number of boards served $(N=155, M$ $=2.0, S D=.587$ ) than other external resources. Websites are followed by print media, such as magazines and journals (Role: $N=154, M=1.8, S D=.852$; Boards Served: $N=$ 114, $M=1.8$ ); then networks (i.e. friends and family; Role: $N=154, M=1.8$; Boards Served: $N=150, M=1.7$ ); then webinars (Role: $N=154, M=1.7$; Boards Served: $N=$ $153, M=1.7$ ); and finally programs (e.g. certification and degree; Role: $N=154, M=1.6$; Boards Served $N=152: M=1.5)$. However, webinars are the same for role and board service.

Table 4.5

Descriptive Data for Frequency of Access of External Sources to Learn about Fiduciary Responsibilities by All Roles

External

\begin{tabular}{lcccccc} 
Source & $\mathrm{N}$ & Mean & Median & Std. Dev. & Minimum & Maximum \\
\hline Websites & 154 & 2.2 & 2 & .946 & 1 & 3 \\
Webinars & 154 & 1.7 & 2 & .800 & 1 & 3 \\
Print & 154 & 1.8 & 2 & .852 & 1 & 3 \\
Network & 154 & 1.8 & 2 & .852 & 1 & 3 \\
Programs & 154 & 1.6 & 2 & .891 & 1 & 3 \\
\hline
\end{tabular}


Table 4.6

Descriptive Data for Frequency of Access of External Types of Sources to Learn about Fiduciary Responsibilities by Board Service

\begin{tabular}{lcccccc}
\hline External & & & & & & \\
Source & $\mathrm{N}$ & Mean & Median & Std. Dev. & Minimum & Maximum \\
Websites & 155 & 2.0 & 2 & .587 & 1 & 3 \\
Webinars & 153 & 1.7 & 2 & .616 & 1 & 3 \\
Print & 114 & 1.8 & 2 & .626 & 1 & 3 \\
Network & 150 & 1.7 & 2 & .636 & 1 & 3 \\
Programs & 152 & 1.5 & 1 & .664 & 1 & 3 \\
\hline
\end{tabular}

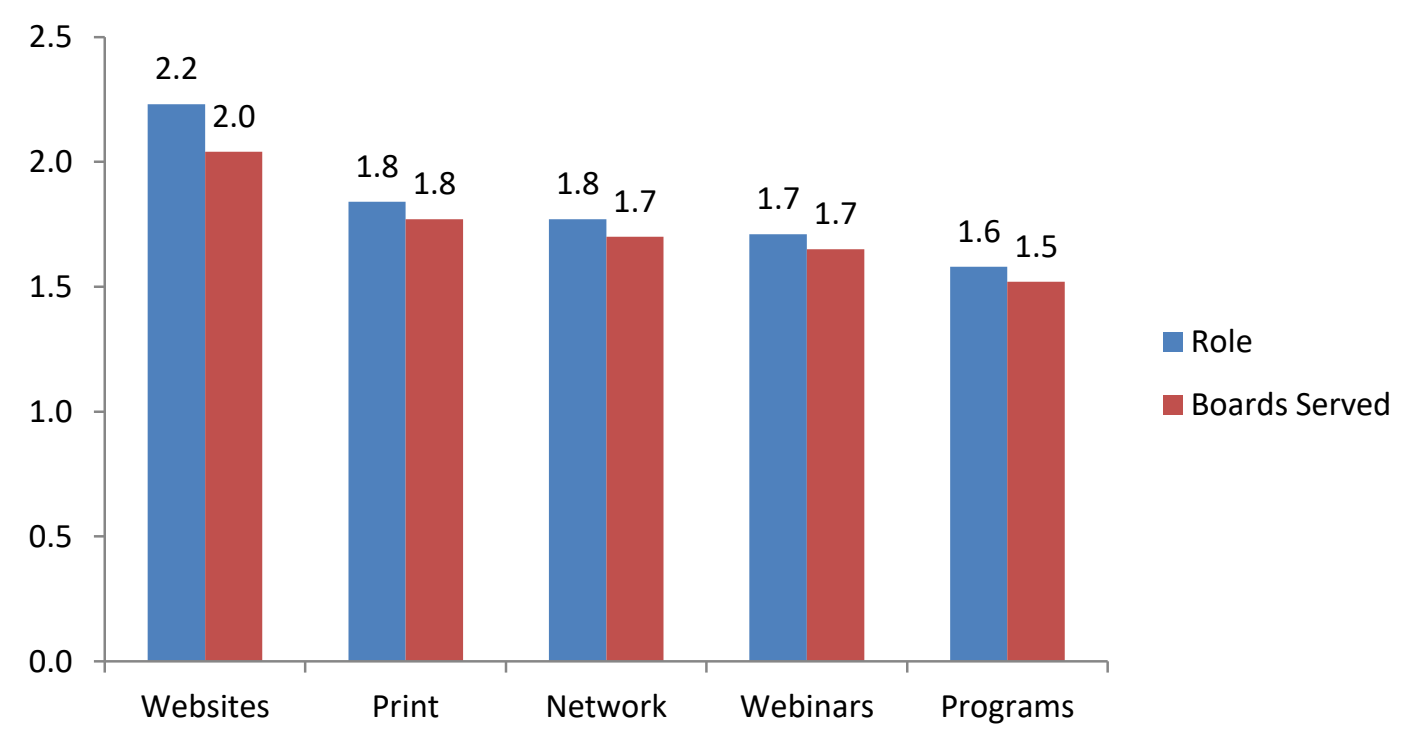

Figure 4.3. Means for Frequency of Access of External Sources Types of Sources to Learn about Fiduciary Responsibilities by All Role and All Boards Served.

By role. When analyzed by role, Table 4.7 presents and Figure 4.4 illustrates the results that board members accessed websites the most $(N=90, M=1.9, S D=.589)$ followed by their networks (i.e. friends and family; $N=89, M=1.8, S D=.691$ ); then print media, such as magazines and journals, $(N=89, M=1.6, S D=.562)$; then webinars $(N=89, M=1.5, S D=.586)$. Academic and certificate programs are the least accessed by board members $(N=89, M=1.4, S D=.615)$. For executives, they too accessed websites the most $(N=72, M=2.2, S D=.537)$. However, the second most accessed external source for executives was print media $(N=72, M=2.0, S D=.617)$ followed by webinars $(N=69, M=1.9, S D=.601)$, then academic and certificate degree programs $(N$ 
$=69, M=1.7, S D=.696)$, and finally networks $(N=68, M=1.6, S D=.547)$ accessed the least.

Table 4.7

Descriptive Data for Frequency of Access of External Sources to Learn about Fiduciary Responsibilities by Roles

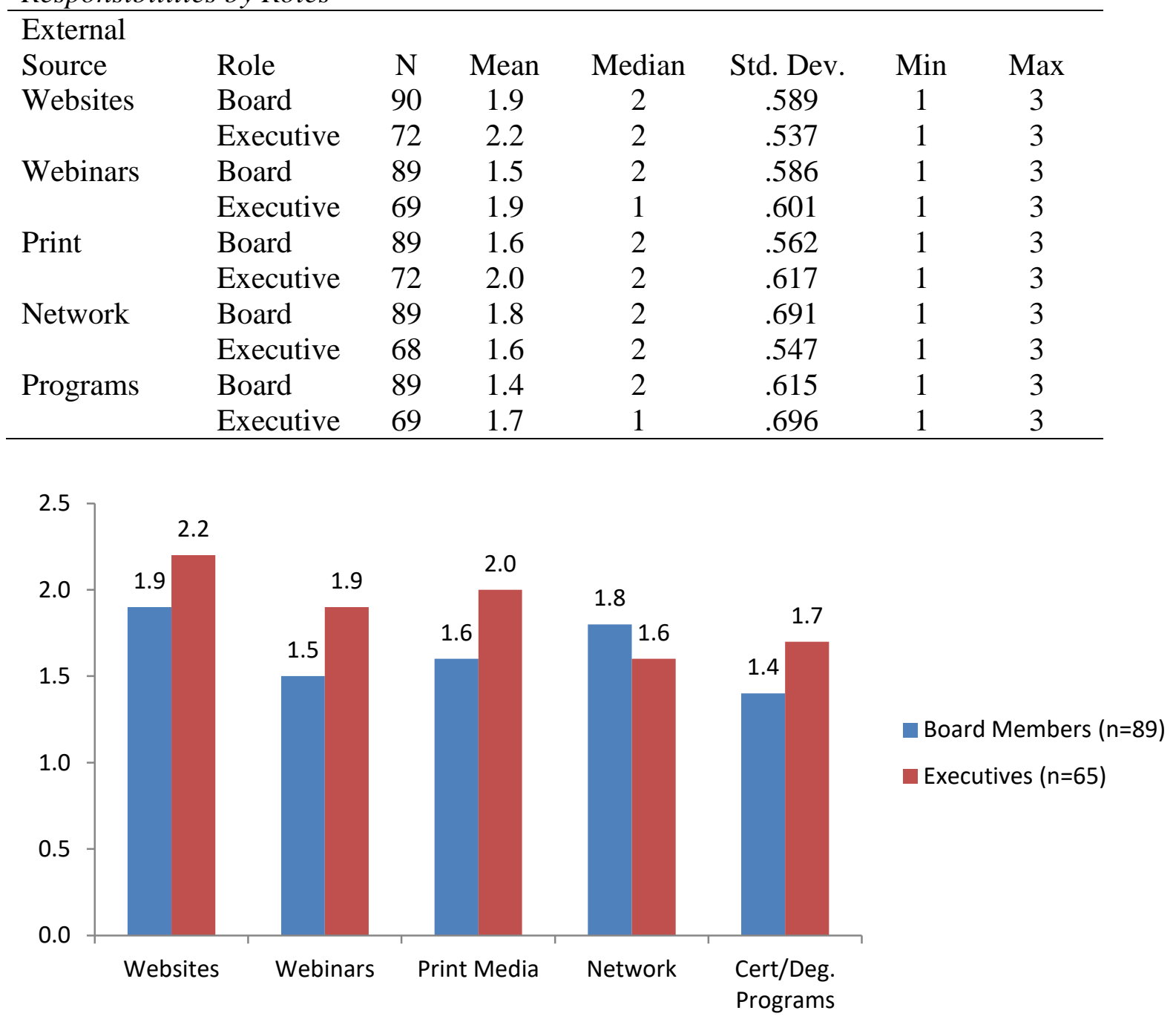

Figure 4.4. Means for Frequency of Access of External Sources Types of Sources to Learn about Fiduciary Responsibilities by All Role.

By board service. Table 4.8 presents and Figure 4.5 illustrates the results when analyzed by the number of boards served, those who have served on six or more boards access websites the most $(N=14, M=2.2, S D=.579)$ compared to those who have served on one to two boards $(N=77, M=1.9, S D=.579)-$ a mean difference of .3. Print 
media, such as journals and magazines, are accessed the same by those who have served on three or more boards (3-4 Boards: $N=8, M=1.9, S D=.652 ; 5-6$ Boards: $N=16 . M=$ $1.9, S D=.500 ;$ and $6+$ Boards: $N=14, M=1.9, S D=.663)$ with slightly less than those who have only served on one to two boards $(N=76, M=1.7, S D=.620)$. Webinars seem to be accessed the most as board service increases (1-2 Boards: $N=75, M=1.6, S D=$ $.620 ; 3-4$ Boards: $N=48, M=1.7, S D=.651 ; 5-6$ Boards: $N=16, M=1.8, S D=.577$; and 6+ Boards: $N=14, M=1.9, S D=.535)$ for a mean difference of .4 between $1-2$ boards and 6 or more boards.

Table 4.8

Descriptive Data for Frequency of Access of External Types of Sources to Learn about Fiduciary Responsibilities by Number of Boards

\begin{tabular}{|c|c|c|c|c|c|c|c|}
\hline $\begin{array}{l}\text { External } \\
\text { Source }\end{array}$ & $\begin{array}{l}\text { Number } \\
\text { of }\end{array}$ & & & & & & \\
\hline & Boards & $\mathrm{N}$ & Mean & Median & Std. Dev. & Min & Max \\
\hline \multirow[t]{4}{*}{ Websites } & $1-2$ & 77 & 1.9 & 2 & .579 & 1 & 3 \\
\hline & $3-4$ & 48 & 2.1 & 2 & .606 & 1 & 3 \\
\hline & $5-6$ & 16 & 2.1 & 2 & .574 & 1 & 3 \\
\hline & $6+$ & 14 & 2.2 & 2 & .579 & 1 & 3 \\
\hline \multirow[t]{4}{*}{ Webinars } & $1-2$ & 75 & 1.6 & 1 & .620 & 1 & 3 \\
\hline & $3-4$ & 48 & 1.7 & 2 & .651 & 1 & 3 \\
\hline & $5-6$ & 16 & 1.8 & 2 & .577 & 1 & 3 \\
\hline & $6+$ & 14 & 1.9 & 2 & .535 & 1 & 3 \\
\hline \multirow[t]{4}{*}{ Print } & $1-2$ & 76 & 1.7 & 2 & .620 & 1 & 3 \\
\hline & $3-4$ & 8 & 1.9 & 2 & .652 & 1 & 3 \\
\hline & $5-6$ & 16 & 1.9 & 2 & .500 & 1 & 3 \\
\hline & $6+$ & 14 & 1.9 & 2 & .663 & 1 & 3 \\
\hline \multirow[t]{4}{*}{ Network } & $1-2$ & 74 & 1.7 & 2 & .677 & 1 & 3 \\
\hline & $3-4$ & 47 & 1.7 & 2 & .623 & 1 & 3 \\
\hline & $5-6$ & 15 & 1.8 & 2 & .561 & 1 & 3 \\
\hline & $6+$ & 14 & 1.6 & 1 & .646 & 1 & 3 \\
\hline \multirow[t]{4}{*}{ Programs } & $1-2$ & 75 & 1.4 & 1 & .605 & 1 & 3 \\
\hline & $3-4$ & 48 & 1.7 & 2 & .724 & 1 & 3 \\
\hline & $5-6$ & 16 & 1.6 & 1 & .629 & 1 & 3 \\
\hline & $6+$ & 13 & 1.7 & 2 & .630 & 1 & 3 \\
\hline
\end{tabular}




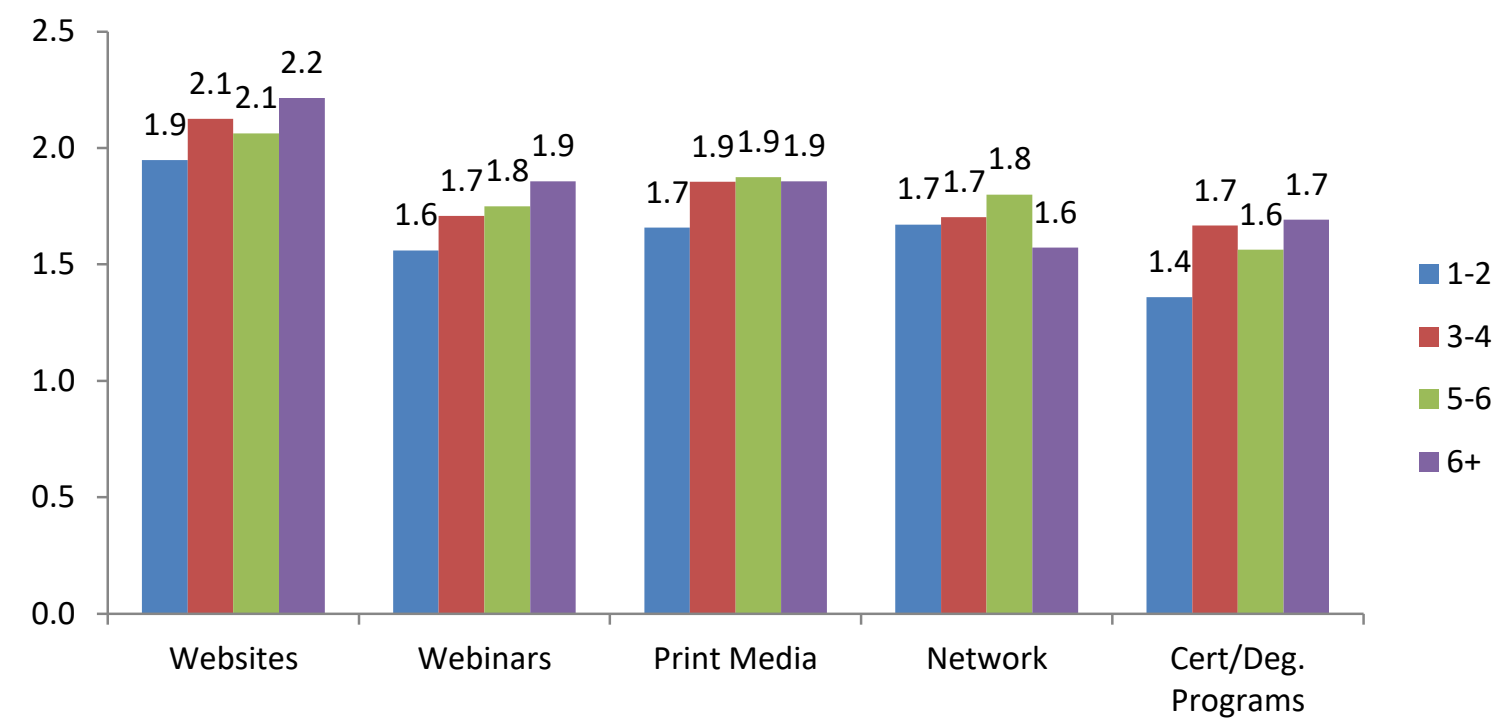

Figure 4.5. Means of Frequency of Access of External Types of Sources to Learn about Fiduciary Responsibilities by Number of Boards.

External source and number of boards served and role. To analyze the patterns of the type of external sources accessed by number of boards served, the following are contingency tables for each of the five external sources (websites, webinars, networks, print media, and degree/certificate programs). While controlling for board service, the following includes my hypothesis for each external source and the results.

Websites. Given the normative pressures to professionalize, nonprofit leaders who have more board service experience would be encouraged to professionalize. This pressure might expose them to a wider variety of training opportunities and therefore know more about websites that focus on governance. This leads to the following hypothesis:

$H_{1}$ : When controlling for the number of boards served, it is expected that board member and executive consultation of external websites to learn about fiduciary responsibilities, increases as board service increases. 
As presented in Table 4.9, when looking at how often board members and executives access external websites, board members increase their access of external websites the more boards they serve on (1-2 boards: $N=46,61 \% ; 3-4$ boards: $N=28$, 61\%; and 5-6/6+ boards: $N=13,62 \%$ ). Executives also increase their use of external websites, however, there is a slight dip once they serve on 3-4 boards (1-2 boards: $N=$ 28, 50\%; 3-4 boards: $N=19,43 \%$; and 5-6/6+ boards: $N=15,62 \%)$.

Based on these results, board members and executives consult external websites to learn about their fiduciary responsibilities increases as board service increases and, therefore, supports the hypothesis.

Table 4.9 Percentage External Website Source by Number of Boards Served and Frequency

\begin{tabular}{lcccccc} 
& \multicolumn{2}{c}{$1-2$ Boards } & \multicolumn{2}{c}{$3-4$ Boards } & \multicolumn{2}{c}{$5-6 / 6+$ Boards } \\
\hline Never & $\begin{array}{c}\text { Board } \\
\text { Member }\end{array}$ & Executive & $\begin{array}{c}\text { Board } \\
\text { Member }\end{array}$ & Executive & $\begin{array}{c}\text { Board } \\
\text { Member }\end{array}$ & Executive \\
\cline { 2 - 7 } Sometimes/ & $39 \%$ & $50 \%$ & $39 \%$ & $37 \%$ & $38 \%$ & $38 \%$ \\
Always & $61 \%$ & $50 \%$ & $61 \%$ & $63 \%$ & $62 \%$ & $62 \%$ \\
Total & $100 \%$ & $100 \%$ & $100 \%$ & $100 \%$ & $100 \%$ & $100 \%$ \\
N & 46 & 28 & 28 & 19 & 13 & 13 \\
\hline
\end{tabular}

Note. Sometimes and Always responses were collapsed into Sometimes/Always and 5-6 Boards and 6+ Boards were collapsed into 5-6/6+ Boards because of small Ns and to reduce instability issues with data.

Webinars. Similar to websites, given the normative pressures to professionalize, nonprofit leaders who have more board service experience would be encouraged to professionalize. This pressure might expose them to a wider variety of training opportunities and as such have a greater awareness of webinars available about governance. This leads to the following hypothesis: 
$\mathrm{H}_{2}$ : When controlling for the number of boards served, it is expected that board member and executive consultation of external webinars to learn about fiduciary responsibilities, increases as board service increases.

As presented in Table 4.10, when looking at how often board members and executives access external webinars, board members increase their access of external websites the more boards they serve on (1-2 boards: $N=45,38 \% ; 3-4$ boards: $N=29$, 52\%; and 5-6/6+ boards: $N=14,57 \%$ ). Executives also increase their use of external resources the more boards they serve on (1-2 boards: $N=30,67 \% ; 3-4$ boards: $N=19$, 74\%; and 5-6/6+ boards: $N=15,87 \%)$.

Based on these results, board members and executives consult external webinars to learn about their fiduciary responsibilities increases as board service increases and, therefore supports the hypothesis.

Table 4.10

Percentage External Webinar Source by Number of Boards Served and Frequency

\begin{tabular}{lcccccc} 
& \multicolumn{2}{c}{$1-2$ Boards } & \multicolumn{2}{c}{$3-4$ Boards } & \multicolumn{2}{c}{$5-6 / 6+$ Boards } \\
\hline & $\begin{array}{c}\text { Board } \\
\text { Member }\end{array}$ & Executive & $\begin{array}{c}\text { Board } \\
\text { Member }\end{array}$ & Executive & $\begin{array}{c}\text { Board } \\
\text { Member }\end{array}$ & Executive \\
\cline { 2 - 7 } Never & $62 \%$ & $33 \%$ & $48 \%$ & $26 \%$ & $43 \%$ & $13 \%$ \\
Sometimes/ & & & & & & \\
Always & $38 \%$ & $67 \%$ & $52 \%$ & $74 \%$ & $57 \%$ & $87 \%$ \\
Total & $100 \%$ & $100 \%$ & $100 \%$ & $100 \%$ & $100 \%$ & $100 \%$ \\
$\mathrm{~N}$ & 45 & 30 & 29 & 19 & 14 & 15 \\
\hline
\end{tabular}

Note. Sometimes and Always responses were collapsed into Sometimes/Always and 5-6 Boards and 6+ Boards were collapsed into 5-6/6+ Boards because of small Ns and to reduce instability issues with data.

Print media. Given the normative pressures for professionalization, it is expected that executives would access external print media more than board members. As executives gain more knowledge and experience in their roles they become more familiar 
with the journals, magazines, and other print media relevant to their field and mission. This leads to the following hypothesis:

$H_{3}$ : When controlling for the number of boards served, it is expected that executives consult external print media to learn about fiduciary responsibilities at a higher rate than board members at all levels of number of boards served on.

As presented in Table 4.11, when looking at the rate that executives access external print media compared to board members, executives access external print media at a higher rate (1-2 boards: $N=31,83 \% ; 3-4$ boards: $N=19,84 \%$; and 5-6/6+ boards: $N$ $=15,80 \%)$ than board members. Board members access external print media at a lower rate than executives ( $1-2$ boards: $N=45,40 \% ; 3-4$ boards: $N=29,62 \%$; and 5-6/6+ boards: $N=14,78 \%$ ).

Based on these results, executives consult external print media sources to learn about their fiduciary responsibilities at a higher rate than board members and, therefore supports the hypothesis.

Table 4.11

Percentage External Print Media Source by Number of Boards Served and Frequency

\begin{tabular}{lllllll} 
& \multicolumn{2}{c}{$1-2$ Boards } & \multicolumn{2}{c}{$3-4$ Boards } & \multicolumn{2}{c}{$5-6 / 6+$ Boards } \\
\hline & \multicolumn{1}{c}{ Board } & \multicolumn{3}{c}{ Board } \\
Member & Executive & Member & Executive & $\begin{array}{c}\text { Moard } \\
\text { Member }\end{array}$ & Executive \\
Never & $60 \%$ & $17 \%$ & $38 \%$ & $16 \%$ & $21 \%$ & $20 \%$ \\
Sometimes/ & & & & & & \\
Always & $40 \%$ & $83 \%$ & $62 \%$ & $84 \%$ & $79 \%$ & $80 \%$ \\
Total & $100 \%$ & $100 \%$ & $100 \%$ & $100 \%$ & $100 \%$ & $100 \%$ \\
$\mathrm{~N}$ & 45 & 31 & 29 & 19 & 14 & 15 \\
\hline
\end{tabular}

Note. Sometimes and Always responses were collapsed into Sometimes/Always and 5-6 Boards and 6+ Boards were collapsed into 5-6/6+ Boards because of small Ns and to reduce instability issues with data. 
Networks. While there are no isomorphic pressures to base the hypothesis on, it is my personal experience newer board members consult their friends and family in order to learn about their fiduciary responsibilities. Therefore, the hypothesis is:

$H_{4}$ : When controlling for the number of boards served, it is expected that board members who have served on 1-2 boards consult their external networks at a higher rate than board members who have served on three or more boards in order to learn about fiduciary responsibilities.

As presented in Table 4.12, when looking at the rate that board members who have served on 1-2 boards access external networks compared to board members who have served on three or more boards, they consult their networks about the same (1-2 boards: $N=46,61 \% ; 3-4$ boards: $N=28,61 \%$; and 5-6/6+ boards: $N=14,64 \%$ ).

Based on these results, board members who have served on 1-2 boards consult their external networks to learn about their fiduciary responsibilities at the same rate as those who have served on 3-4 boards, but less than those who have served on 5-6/6+ boards, and therefore does not support the hypothesis.

Table 4.12

Percentage External Networks Source by Number of Boards Served and Frequency

\begin{tabular}{lcccccc} 
& \multicolumn{2}{c}{$1-2$ Boards } & \multicolumn{2}{c}{$3-4$ Boards } & \multicolumn{2}{c}{$5-6 / 6+$ Boards } \\
& $\begin{array}{c}\text { Board } \\
\text { Member }\end{array}$ & Executive & $\begin{array}{c}\text { Board } \\
\text { Member }\end{array}$ & Executive & $\begin{array}{c}\text { Board } \\
\text { Member }\end{array}$ & Executive \\
\cline { 2 - 7 } Never & $39 \%$ & $50 \%$ & $39 \%$ & $37 \%$ & $36 \%$ & $36 \%$ \\
Sometimes/ & & & & & & \\
Always & $61 \%$ & $50 \%$ & $61 \%$ & $63 \%$ & $64 \%$ & $64 \%$ \\
Total & $100 \%$ & $100 \%$ & $100 \%$ & $100 \%$ & $100 \%$ & $100 \%$ \\
N & 46 & 28 & 28 & 19 & 14 & 14 \\
\hline
\end{tabular}

Note. Sometimes and Always responses were collapsed into Sometimes/Always and 5-6 Boards and 6+ Boards were collapsed into 5-6/6+ Boards because of small Ns and to reduce instability issues with data. 
Certificate and degree programs. Similar to websites and webinars, given the normative pressures to professionalize, nonprofit leaders who have more board service experience would be encouraged to professionalize. This pressure might expose them to a wider variety of training opportunities and may lead them to access long-term trainings such as certificate and degree programs. This leads to the following hypothesis:

$H_{5}$ : When controlling for the number of boards served, it is expected that executive consultation of external certificate and degree programs to learn about fiduciary responsibilities, increases as their board service increases.

As presented in Table 4.13, when looking at how often executives access external certificate and degree programs, the rate increases the number of boards they serve on (12 boards: $N=30,40 \% ; 3-4$ boards: $N=19,63 \%$; and 5-6/6+ boards: $N=14,71 \%$ ).

Based on these results, executives consultation of external certificate and degree programs to learn about their fiduciary responsibilities increases as their board service increases and, therefore, supports the hypothesis.

Table 4.13

Percentage External Certificate and Degree Programs Source by Number of Boards Served and Frequency

\begin{tabular}{lcccccc}
\hline & \multicolumn{2}{c}{$1-2$ Boards } & \multicolumn{2}{c}{$3-4$ Boards } & \multicolumn{2}{c}{$5-6 / 6+$ Boards } \\
\cline { 2 - 6 } & $\begin{array}{c}\text { Board } \\
\text { Member }\end{array}$ & Executive & $\begin{array}{c}\text { Board } \\
\text { Member }\end{array}$ & Executive & $\begin{array}{c}\text { Board } \\
\text { Member }\end{array}$ & Executive \\
\cline { 2 - 7 } Never & $78 \%$ & $60 \%$ & $55 \%$ & $37 \%$ & $57 \%$ & $29 \%$ \\
Sometimes/ & & & & & & \\
Always & $22 \%$ & $40 \%$ & $45 \%$ & $63 \%$ & $43 \%$ & $71 \%$ \\
Total & $100 \%$ & $100 \%$ & $100 \%$ & $100 \%$ & $100 \%$ & $100 \%$ \\
N & 45 & 30 & 29 & 19 & 14 & 14
\end{tabular}

Note. Sometimes and Always responses were collapsed into Sometimes/Always and 5-6 Boards and 6+ Boards were collapsed into 5-6/6+ Boards because of small Ns and to reduce instability issues with data. 


\section{Sources and Actual Knowledge}

Using the results from chapter three, nonprofit leaders whose actual knowledge of fiduciary duties that received a passing grade was analyzed with the frequency they accessed internal sources. The following are the results.

Internal sources. When analyzed by role, Table 4.14 presents and Figure 4.6 illustrates the results for internal sources that nonprofit leaders whose actual fiduciary knowledge score was a "C" or better accessed to learn about their fiduciary responsibilities. Board members $(N=73)$, accessed board orientations $(59 \%)$, followed by board manuals (56\%), then informal conversations $(54 \%)$, and finally educational opportunities (51\%). For the executives, whose actual fiduciary knowledge was a "C" or better $(N=61)$, they accessed educational opportunities $(49 \%)$ the most followed by informal conversations (46\%), then board manuals (46\%), and lastly orientations (41\%).

Table 4.14

Descriptive Data for Nonprofit Leaders with a Passing Score for Knowledge and the Type of Internal Sources Access by Role

Role N Orientation Informal Educational Board

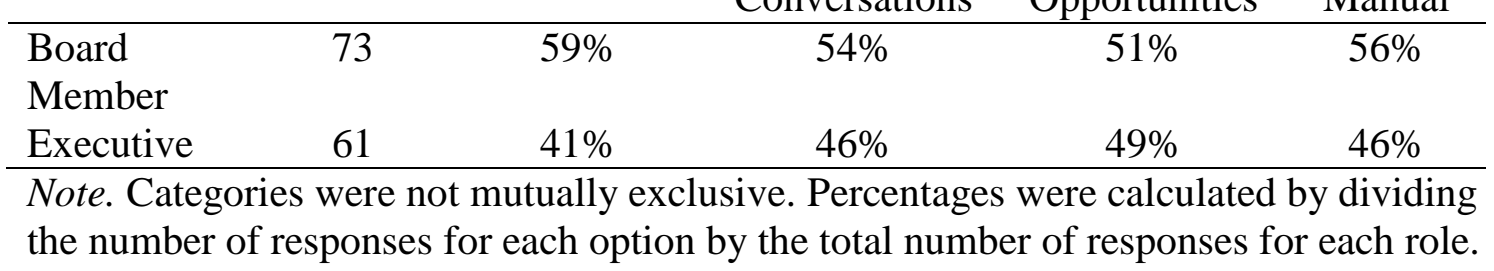




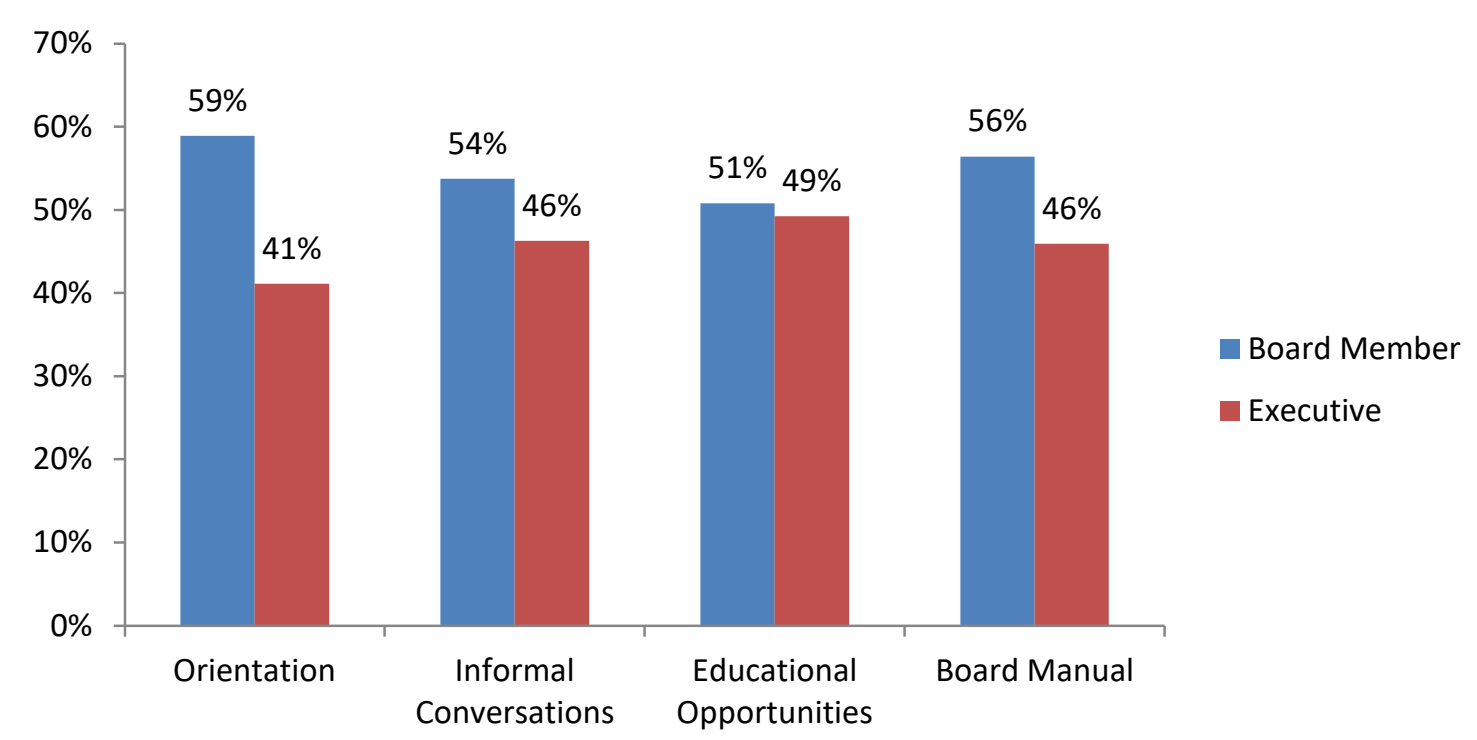

Figure 4.6. Percentage of Nonprofit Leaders with a Passing Score for Knowledge and the Type of Internal Sources Access by Role. Note. Categories were not mutually exclusive. Percentages were calculated by dividing the number of responses for each option by the total number of responses for each role.

When analyzed by number of boards served, Table 4.15 presents and Figure 4.7

illustrates the results for internal sources that nonprofit leaders whose actual fiduciary knowledge score was a "C" or better accessed to learn about their fiduciary responsibilities. Informal conversations are the most accessed for all categories of board service (1-2 boards: $N=79,86 \% ; 3-4$ boards: $N=48,94 \% ; 5-6$ boards: $N=16,100 \%$; and more than six boards: $N=14,93 \%$ ). Educational opportunities are the least accessed source for nearly all of the categories board service, except for those serving on more than six boards ( $1-2$ boards: $N=79,42 \% ; 3-4$ boards: $N=48,56 \% ; 5-6$ boards: $N=16$, $38 \%$; and more than six boards: $N=14,64 \%$ ). 
Table 4.15

Descriptive Data for Nonprofit Leaders with a Passing Score for Knowledge and the Type of Internal Sources Access by Board Service

\begin{tabular}{lccccc}
$\begin{array}{l}\text { Number of } \\
\text { Boards }\end{array}$ & $\mathrm{N}$ & Orientation & $\begin{array}{c}\text { Informal } \\
\text { Conversations }\end{array}$ & $\begin{array}{c}\text { Educational } \\
\text { Opportunities }\end{array}$ & $\begin{array}{c}\text { Board } \\
\text { Manual }\end{array}$ \\
\hline $1-2$ & 79 & $44 \%$ & $86 \%$ & $42 \%$ & $59 \%$ \\
$3-4$ & 48 & $58 \%$ & $94 \%$ & $56 \%$ & $63 \%$ \\
$5-6$ & 16 & $44 \%$ & $100 \%$ & $38 \%$ & $50 \%$ \\
$6+$ & 14 & $79 \%$ & $93 \%$ & $64 \%$ & $57 \%$ \\
\hline
\end{tabular}

Note. Categories were not mutually exclusive percentage were calculated by dividing the number of responses for each option by the total number of responses for each category of board service.

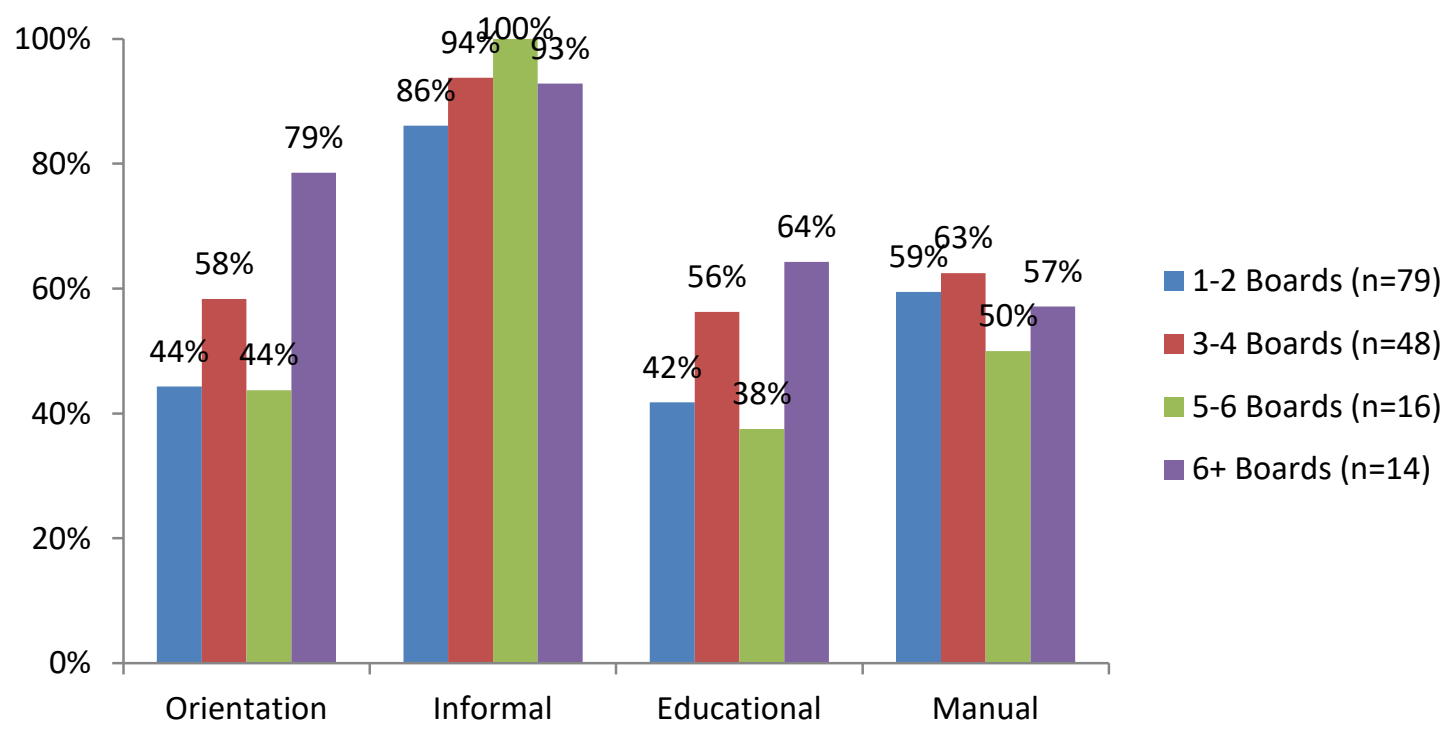

Figure 4.7. Percentages for Nonprofit Leaders with a Passing Score for Knowledge and the Type of Internal Sources Access by Board Service. Note. Categories were not mutually exclusive. Percentages were calculated by dividing the number of responses for each option by the total number of responses for each category of board service.

\section{Discussion}

This chapter presented the results of what types of internal and external sources (best practices) nonprofit leaders (board members and executives) access to learn about their fiduciary roles and responsibilities to demonstrate legal accountability. While this study is exploratory in that it pilots an assessment tool and seeks to establish baseline 
data for future research, it highlights the need for a greater awareness of fiduciary responsibility knowledge.

\section{Internal Sources}

Despite their role or the numbers of boards they have served on the past 15 years, nonprofit leaders relied more on informal conversations to learn about their fiduciary duties more than any other internal best practice. The results resonate with a small-scale study by Castor and Jiter (2013). The authors interviewed twenty six board members with a variety of board service backgrounds to better understand board member roles and responsibilities via socialization. The majority of those interviewed shared that they learned about their roles and responsibilities informally, through observation and "osmosis". One member went so far to say that they learned by "the seat of their pants" highlighting the informal nature of board training (Castor \& Jiter, 2013, p. 88).

Because of the social nature of nonprofits, in that most of the services and programs provided involve interacting with people, it should not come as a surprise that a "mirroring" effect could occur in the organization itself. As organizations interact with their clients, providing programs, services, and education, the behavior of its leaders also requires a certain level of personal engagement as well as transfer of knowledge and best practices amongst themselves. More research is needed to further explore this idea, however, recognizing the social nature of nonprofit leadership may help support trainings that focus on mentoring such as "board buddies" and orientation workshops that are more interactive and less procedural and formal in nature.

After informal conversations with colleagues, board members and executives accessed board manuals similarly. After manuals, board members accessed educational 
opportunities then board orientations; while executives, particularly those who have served on more than six boards in the past 15 years, accessed board orientations then educational opportunities. However, executives who have served on one to two boards accessed the board manual over the board orientation. One possible explanation for these results could be that nonprofit leaders with more board tenure might prefer attending an orientation to ask specific questions about an organization that might not be otherwise be included in a board manual. Conversely, nonprofit leaders with less board tenure seem to rely on the board manual more than orientation, which may be attributed to convenience, reviewing a board manual can be done on their own time rather than attending a board orientation. Or, it could be that nonprofit leaders who are new to board service believe that the board manual is more important because it is a more detailed version of an orientation.

The use of more formalized best practices is also the case for nonprofit leaders who scored a "C" or better in terms of their actual fiduciary knowledge, regardless of their role. The use of a board orientation was discussed when Brown (2007) found that although the orientation process was moderately utilized (2.8 out of 5-point Likert scale) after applying a structural equation model, he found a strong relationship between board orientation and board performance. However, when analyzed by number of boards served, nonprofit leaders who scored a "C" or better for their actual fiduciary knowledge accessed informal sources the most. This is puzzling, because one might expect that those with more accurate knowledge would use more formalized best practices. However, in this study this does not seem to be the case. 
These results raise important questions about the quality of fiduciary knowledge. The informal nature that nonprofit leaders access to acquire their knowledge may be inferior to other more established best practices such as a board orientation, board manual, or educational opportunities provided by the organization. This might indicate that the behavior is decoupled from how the leaders meet external demands for accountability and legitimacy. De-coupling is the proposition that organizations decouple (separate) when they say one thing and do another (Boxenbaum \& Jonsson, 2017). So, although organizations can demonstrate to external stakeholders, such as regulators, that they have best practices available, what this study found is that nonprofit leaders do not access the more established best practices. From a legal accountability perspective, if nonprofit leaders are relying on informal conversations with one another, how can the accuracy of the information be verified?

\section{External Sources}

Regardless of the role or number of boards served, overall nonprofit leaders accessed external websites the most to learn about their fiduciary duties. Following websites are print media, networks, and certificate and degree programs. Without any previous studies to build on, these differences may be attributed to the availability (e.g. online access to webinar providers or print media subscriptions) or awareness of the available sources. In looking at the isomorphic pressures that may compel nonprofit leaders to access certain resources, what follows is a discussion about the hypothesis and findings of analyzing external sources and controlling for board service.

Websites. My hypothesis, that board members and executives consult external websites to learn about their fiduciary responsibilities increases as board service increases 
was supported. Based on the normative pressures to professionalize, nonprofit leaders who have a great deal of board service experience would be encouraged to professionalize. As noted in the results, although executives overall increased their access of external websites the more board service they gained, there was a slight dip once they serve on three to four boards. One possible explanation for this is that after a few boards under their belt, executives may feel that they have enough knowledge to fulfill their responsibilities. Once they go beyond four boards, they may serve on an entirely new organization and learn that they have more to learn. However, without more research, this is just a theory.

Webinars. The hypothesis, it is expected that board member and executive consultation of external webinars to learn about fiduciary responsibilities, increases as board service increases was supported. Based on normative pressures to professionalize, it was hypothesized that the more board service results in a greater awareness of the webinar resources available that focused on governance training. Executives consistently increased their access of webinars the more boards they serve on. For board members, there is a noticeable increase in access of webinars after serving on at least two boards. Board members who serve on three to four boards, they access webinars $14 \%$ more than those who have served on less than three boards. More research is needed to understand why this is.

Print media. The hypothesis, it is expected that executives consult external print media to learn about fiduciary responsibilities at a higher rate than board members at all levels of number of boards served on was supported. The mimetic pressures that cause nonprofits to adopt similar practices that other nonprofits utilize can be seen in the types 
of resources nonprofit leaders utilize. As executives interact with their colleagues on a regular basis, they become more familiar with the journals, magazines, and other print media relevant to their field and mission.

What is interesting to note about these results is that although executives accessed external print media at a higher rate than board members, executive access decreased the more boards they serve on (1-2 boards: 83\%; $3-4$ boards: $84 \%$; and 5-6/6+ boards: $80 \%)$, whereas board members increased their access with increased board service (1-2 boards: 40\%; 3-4 boards: 62\%; and 5-6/6+ boards: 79\%). These results may point to board members experiencing the same normative pressures that executives do. And, the results may suggest a saturation point that executives reach in terms of how much print media might be available. However, further research is needed.

Networks. The hypothesis, it is expected that board members who have served on 1-2 board consult their external networks at a higher rate than board members who have served on three or more boards was not supported. This hypothesis was harder to categorize in any of the isomorphic pressures and was meant to be purely exploratory in nature. The reasoning was that newer board members might be shy to ask their organizations for more information and would feel more comfortable with their peers. However, the results show the opposite: the more experience board members (1-2 boards: 61\%; 3-4 boards: $61 \% ; 5-6 / 6+$ boards: $64 \%)$ and executives (1-2 boards: 50\%; 3-4 boards: $63 \%$; and 5-6/6+ boards: $64 \%$ ) have, the more they consult their external networks. These results may be explained by the informal, social nature that nonprofit leaders learn about their fiduciary responsibilities. As presented earlier in this chapter, 
nonprofit leaders tend to rely more on conversations with their colleagues rather than formal governance best practices. However, more research is needed to fully explore.

Certificate and degree programs. The hypothesis, it is expected that executive consultation of external certificate and degree programs to learn about fiduciary responsibilities, increases as their board service increases, was supported. The normative pressures to professionalize was the basis for this hypothesis given that executives who want more legitimacy would be most likely to pursue some sort of academic or certificate program to demonstrate competency and skill.

What is interesting to note about these findings is that board members rate of accessing external certificate and degree programs also increases as board service increases (1-2 boards: 22\%; 3-4 boards: 45\%; and 5-6/6+ boards: 43\%). The amount nearly doubles from $1-2$ boards (22\%) to 5-6/6+ boards (43\%). This could be because nonprofit leaders who serve on more boards are exposed to the many faces of nonprofit management and leadership, therefore, would be interested in learning more about how best to govern and monitor the organizations they serve as a board member for. Again, more research is needed to better understand why.

\section{Implications}

The results contribute to the need for a standardize process of accountability by developing nonprofit leader trainings using established best practices. The study highlights the need for more interactive, personable approaches to best practices to ensure that nonprofit leaders have the necessary and appropriate knowledge to fulfill their fiduciary duties. Along with the suggestions mentioned previously, opportunities abound for regulators to work in partnership with nationally recognized nonprofit organizations 
such as BoardSource, National Council of Nonprofits, and state nonprofit associations such as California Association of Nonprofits and the Minnesota Council of Nonprofits to develop best practices that assist nonprofit leaders fulfill the fiduciary duties.

Other opportunities to increase fiduciary awareness and knowledge for nonprofit leaders include funders. Funders have the ability to support trainings and workshops to strengthen their grantees by providing incentives and additional grant money as part of grant programs. An example of this is found in a partnership between the City of San Diego and the Nonprofit Institute at the University of San Diego. Using community and business development funds, the City of San Diego funds a two-day intensive Nonprofit Academy, free of charge, to any tax exempt organization located in the City of San Diego. The academy includes sessions related to the various aspects of leading and managing a nonprofit organization including governance (City of San Diego, n.d.).

Finally, nonprofit leaders can use the results of this study to develop best practices that board members and executives will access more frequently. Given the informal nature of the types of best practices nonprofit leaders access more frequently, means to learn about fiduciary responsibilities should have a personal element included. As mentioned before, the idea of board buddies may support nonprofit fiduciary knowledge development. However, it is important to ensure that the board buddy has the appropriate knowledge to begin with.

\section{Future Research}

This study highlights the need for more research around the contextual nature of best practices and how they support legal demands for accountability and pressures for legitimacy. Additional usage of the assessment tool developed for this study can develop 
empirical evidence related to accountability, fiduciary knowledge, and individual nonprofit leaders. Furthermore, continued use of the assessment would strengthen the empirical research around institutionalism and nonprofit governance.

Qualitative research would be a logical next step to this study. Asking nonprofit leaders more in depth questions about the types of best practices they use and why may provide additional insight into the contextual nature of nonprofits and other best practices that may be accessed that are yet to be discovered. And, finally, there is the opportunity to perform additional quantitative analysis, such as regression and more correlation tests with the data collected for this study. Looking at the data in multiple ways may reveal new results.

The following chapter builds on these findings by presenting results about how frequently nonprofit leaders apply their fiduciary knowledge in their governance activities. 


\section{CHAPTER 5: APPLICATION OF FIDUCIARY DUTY KNOWLEDGE}

Nonprofits are held accountable by a variety of stakeholders. In terms of legal accountability, nonprofit leaders are responsible to perform their governance oversight duties in a manner that upholds federal and state expectations. As such, nonprofits are legally held accountable to know what their legal responsibilities are (what). How they fulfill accountability is by accessing appropriate sources, or best practices, to learn about their fiduciary responsibilities (how). The third leg of the accountability stool is demonstrated when nonprofit leaders apply their fiduciary knowledge in the performance of their governance activities to meet legal accountability demands (whom).

A national survey of nonprofit leaders reported that $71 \%$ of the executives and $74 \%$ of the board chairs agreed or strongly agreed that the majority of their board was actively engaged in overseeing and governing the organization (BoardSource, 2017, p. 20). The results of this study found that board members and executives indicated that they applied their fiduciary knowledge frequently in the performance of their duties meaning that they are more engaged than the national statistics. Yet, the results of this study highlight a gap between nonprofit leader performance of their duties and their actual knowledge of what those duties entail. Therefore, it comes as no surprise that according to Stanford (2017) 56\% of the organizations surveyed rated board governance as the most challenging area of strategic leadership.

In this study, when nonprofit leaders were asked about the frequency with which they applied their fiduciary knowledge in the performance of their duties, the results indicate a high frequency in that they most of the time or always (for board members) or somewhat agree and agree (for executives). However, when they were tested for their 
actual knowledge of the legal responsibilities, only $41 \%$ of the board members and $70 \%$ of the executives received a passing score. These results point to two issues: 1) what knowledge are nonprofit leaders using in the performance of their duties and; 2) if they lack the appropriate knowledge, how might their decisions be impacted?

This chapter focuses on nonprofit leader application of fiduciary knowledge in the performance of their governance activities as a means to meet the legal accountability for whom, as illustrated in Figure 5.1.

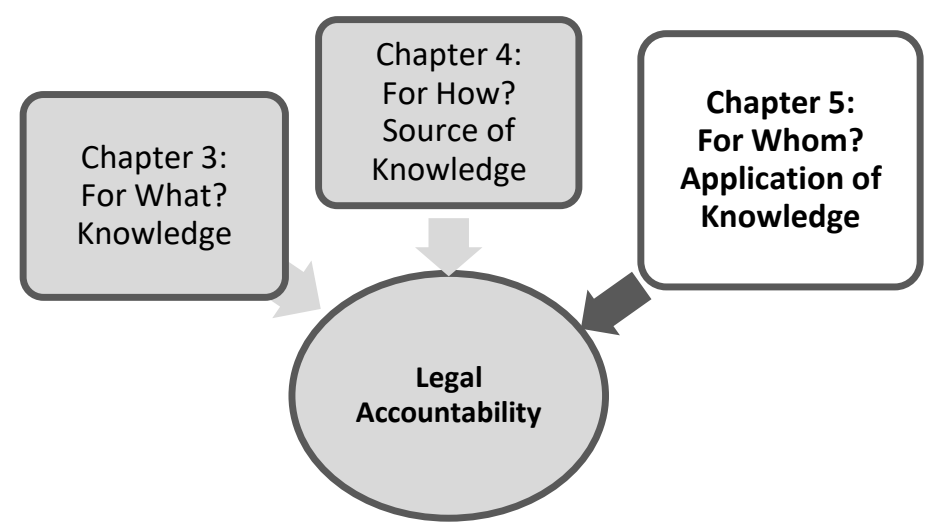

Figure 5.1. Framework for Legal Accountability.

In order for nonprofit leaders to meet demands for accountability by regulators, they must demonstrate competence in the performance of their fiduciary responsibilities. Holland and Ritvo (2008) argued that competencies are a combination of "skills, knowledge, information, and personal characteristics" (p. xvii) that must be practiced in order to be considered useful. They go on to explain that competency is linked to performance and when appropriate competencies are in place, effectiveness follows (Holland \& Ritvo, 2008). The idea of competency aligns with the last two levels of Miller's model of knowledge assessment (1990), the "shows how" and "action" levels, which emphasizes the performance or action as illustrated in Figure 5.2. Miller (1990) 
establishes that knowledge alone is not an adequate measure of performance, but rather suggests how knowledge is performed is a better indicator.

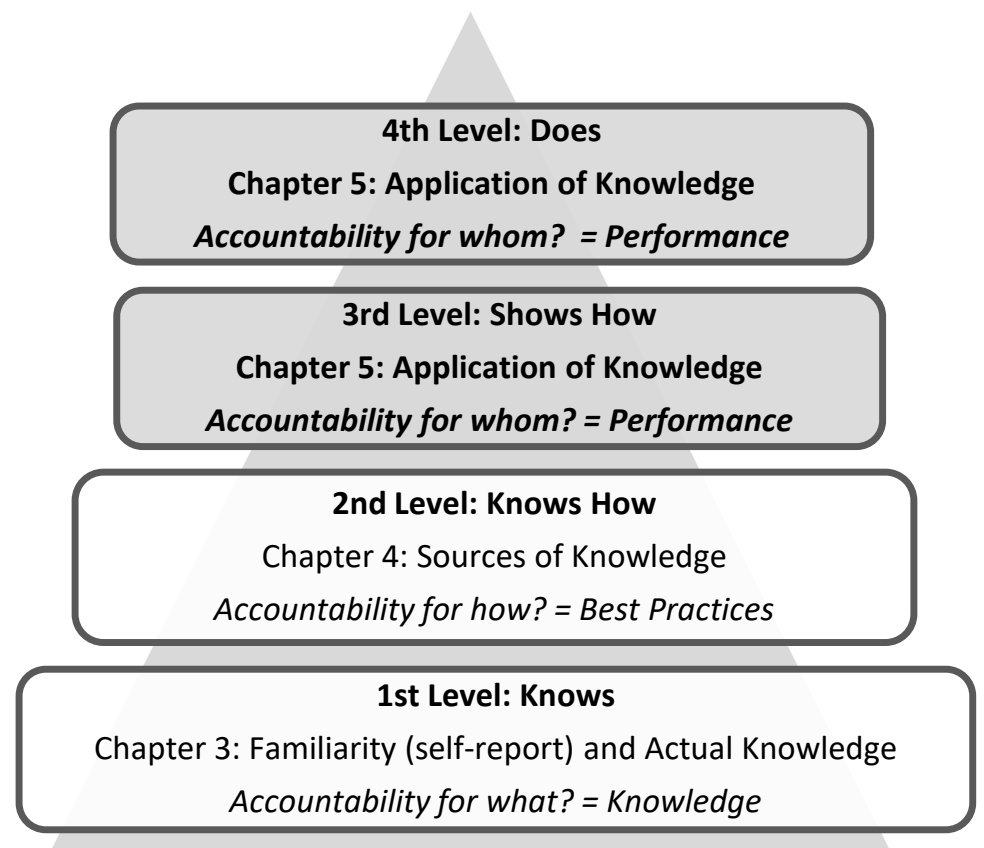

Figure 5.2. Constructs and Legal Accountability.

The premise of this chapter is that legal accountability is demonstrated when nonprofit leaders fulfill their fiduciary responsibilities in the performance of their governance duties. The chapter begins with a discussion about to whom nonprofit leaders (board members and executives) are accountable to, specifically state and federal regulators. After the discussion about accountability to whom, performance, effectiveness, and efficiency are explained followed by ownership and role ambiguity. Then, the results of how frequently nonprofit leaders apply their knowledge of their fiduciary responsibilities in the performance of their governance activities is presented. The chapter ends with a discussion about the results and future research. 


\section{What is Accountability?}

As prevalent as the idea is, accountability is a complex, multi-dimensional concept that means different things to different people. Koppell (2005) offers that where someone is situated impacts how accountability is defined and suggests that accountability should be based on the expectations of the relationship itself. Accountability used in a more popular view, focuses on the public's expectations of “organizational performance, responsiveness, and even morality” (Kearns, 1996, p. 9). To further define to whom are nonprofits accountable, Kearns suggests that an element of accountability involves answering to a "higher authority" (1996, p. 7), which results in compliance in reaction to requirements or obligations (Ebrahim, 2010; Holland \& Ritvo, 2008; Kearns, 1996).

Accountability can also be described as proactively responding to the needs of its constituents (Renz, 2010) and, given the multi-dimensionality, each constituent has differing expectations for what accountability looks like. Ebrahim (2010) discusses accountability in terms of internal dimension and external dimensions. The internal dimension focuses on motivation or responsibility whereas the external dimension is more about obligation (Ebrahim, 2010). Given the many explanations of accountability, Koppell (2005) cautions that "layering every imagined meaning of accountability into a single definition would render the concept meaningless" (p. 95).

\section{Accountability to Whom?}

Because nonprofits are held accountable by a variety of stakeholders, Ebrahim (2010) and others (Scott, 2000; Verschuere, et al., 2006) suggest that in order to tease out to whom nonprofits are accountable, an upward and downward perspective is useful. 
Upward accountability refers to external relationships with funders, governments, and the public whereas downward accountability focuses on internal relationships with clients, staff, and volunteers (Ebrahim, 2010). In a nonprofit context, upward and downward relationships identify the many different stakeholders and the varying degrees of accountability demands they face.

For example, when using a legal or regulatory perspective, nonprofits have an upward relationship with state and federal agencies and are accountable to fulfill their fiduciary responsibilities, but a downward relationship would focus on having the appropriate human resource policies in place for staff. However, other stakeholder perspectives may not be as cut and dry. The public, for example encompasses both an upwards and downwards relationship. Upwardly, the public, (i.e. the general population) has an expectation that nonprofits use donations for the missions. In a downward relationship, the public (i.e. individuals) expects nonprofit to carry out their mission, but are more personally invested since they rely on the programs and services that meet their specific needs.

Similar to Ebrahim's (2010) upward and downward idea, Kearns (1996), offered two ways that nonprofits perform for accountability, explicit and implicit. Explicit accountability focuses on how nonprofits perform their work in order to meet legal, regulatory, or contractual standards (Kearns, 1996). Implicit standards are harder to define, because they relate to societal norms and beliefs about public interest and trust (Kearns, 1996). The upward and downward perspective takes into account the multiple demands for accountability, while the explicit and implicit idea adds a performance element to how accountability is actually carried out. 
Koppell (2005) identified how multiple stakeholders add levels of complexity in his "multiple accountabilities disorder (MAD)" (p. 95). MAD acknowledges that although there are many stakeholders to consider, they must be considered simultaneously. An example of MAD can be seen in Ronald McDonald House Charities (RMHC), a nonprofit organization with chapters around the United States and around the world whose mission is to provide a "home away from home" for families with critically ill children. The national headquarters holds each of the local chapters accountable to ensure that policies, procedures, McDonald's corporate licensing and branding, as well as program protocols are followed. However, concurrently, the local chapter is accountable to their local funders, partner hospitals, and city and state regulators.

Ebrahim (2010) suggested that multi-dimensionality creates challenges for nonprofit leaders in deciding not only what they should be accountable for, but also to whom. Holland (2002) echoes this challenge by adding that not much is known about how nonprofit leaders really "deal with accountability" (p. 412). Therefore, parsing out to whom nonprofit are accountable is no easy task. However, the upward and downward perspective, along with MAD, suggests that how nonprofit leaders perform their governance duties could be a mechanism that helps to meet multiple accountability demands from multiple stakeholders. As such, legal accountability can be demonstrated through the performance of the duties of care, loyalty, and obedience, because these duties provide a legal basis for what is expected of nonprofit leader oversight. Additionally, the duties are based in United States case law are the "legal standards by which all actions taken by directors are judged" (Hopkins, 2009, p. 13) which become the standard by which all tax-exempt organizations will be judged, if necessary. What this 
means for nonprofits is that in order to satisfy legal accountability, they must be both responsive in meeting the demands of the public, using public resources for a public benefit and responsible for following the rules, their fiduciary duties). Therefore, in looking at legal accountability through a fiduciary, legal lens, nonprofits are required to perform their duties in a manner that fulfilling their fiduciary responsibilities.

\section{Performance as Accountability}

Performance is an area that has gained considerable attention in the nonprofit literature over the past few decades. As with accountability, performance is also complex and multi-dimensional. Although there are varying perspectives of what performance means, scholarship has come to an agreement that, at some level, demonstrating accountability and meeting performance demands impacts effectiveness (Berman, 2006; Light, 2004; Preston \& Brown, 2004; Renz, 2010; Salamon, 2012). The following section discusses performance as a means to address legal accountability to whom and establishes nonprofit leaders as "owners" or "stewards' of their organizations. As stewards, they are held accountable for upholding their fiduciary responsibilities as they perform their governance duties.

Knowing what the fiduciary responsibilities are is critical for any nonprofit leader, because most of the decisions nonprofit leaders make in their governance activities should be based in the duties of care, loyalty, and obedience. Jackson and Holland (1998) developed an assessment tool to measure board performance that included six dimensions (contextual, educational, interpersonal, analytical, political, and strategic), which they identified as having a positive impact on board performance. The educational dimension, how well boards were informed about their responsibilities, was considered to be one of 
the strongest dimensions with which to assess board performance (Jackson \& Holland, 1998). Chapter three provides insight into the gap between nonprofit leaders familiarity with the fiduciary duties compared to their actual fiduciary knowledge, which can affect nonprofit leaders' performance of their fiduciary duties. However, having a level of knowledge or competency is just the first step to fulfilling fiduciary duties, because applying that knowledge in the performance of governance activities is a critical next step.

\section{What is Performance?}

Performance is traditionally discussed in the literature as a means for effectiveness and efficiency. It is a broad term that connotes meeting a standard either real or perceived. This study does not measure performance, effectiveness, or efficiency, but rather uses nonprofit leader performance of their governance duties as a means to measure their legal accountability. As such, this study looks at how nonprofit leaders apply their fiduciary knowledge in the performance of their fiduciary duties. But, before further explanation of how performance is applied in this study, a little bit about how performance and accountability intersect follows.

Using Ebrahim's (2010) framework of internal and external demands for accountability, as mentioned previously, helps in explaining how accountability intersects with performance. Given that the external dimension of accountability is more about obligation whereas the internal dimension focuses on motivation or responsibility externally, it could be said that nonprofits are obligated to the media, state and federal regulators, as well as the public. These external actors have a great deal of influence on a nonprofit's reputation, for better or worse, and have a captive audience with which to 
highlight nonprofits who veer away from expectations as seen in recent examples of nonprofit mismanagement as mentioned earlier, Wounded Warrior Project, Central Asia Institute, and United Way. Examples of other external actors monitoring nonprofit performance are charity watchdogs such as Charity Navigator, Guidestar, Better Business Bureau, and the National Center for Charitable Statistics. These watchdogs give scores to nonprofits, usually around financial, transparency, and governance data collected from annual IRS 990 tax returns. The ratings are intended to provide a stamp of approval and are available to the public. However, each watchdog varies as to how they calculate their ratings (Smith, 2014; Worth, 2017) contributing to the contextual nature of accountability and performance.

Looking at the internal dimensions of accountability board members and executives come to mind as those who in theory, would be motivated by responsibility. As the primary governance body, responsible for oversight and management of the organization, it is the board and the executive who bear the brunt of mismanagement and wrongdoing. Given the earlier examples of nonprofit mismanagement, the common thread in each of the scandals was the governance and executive bodies' lack of fiduciary care and oversight of human, physical, or financial resources. Once the stories went public, the organizations suffered from tarnished reputations resulting in decrease in donations and public trust. Furthermore, it was the external legal stakeholders, the IRS, the State Attorney Generals, and the U.S. Congress, that stepped in to hold nonprofit leaders held accountable for how they failed in the performance of their fiduciary duties. 


\section{Performance for Legal Accountability}

Hatry suggests that the primary use of performance measurements are "to establish accountability" (as cited in Positer, 2008, p. 13). Poister (2008) offered that the regulatory accountability mandates from the past few decades are the foundation for much of the performance discussions of today. The federal government began the push for performance and accountability when in 1993 the Government Performance and Results Act (GPRA) was passed requiring government agencies to develop goals and objectives to demonstrate performance (Positer, 2008, p. 17). In 2010, the GPRA was revised, resulting in the Government Performance and Results Modernization Act (GPRAMA) that added new goal-setting and performance measurement processes applicable to multiple agencies, increased internet reporting measures, and more accountability for goals (Positer, 2008; Brass, 2012). Because many nonprofits have contracts for service with government agencies, particularly health and human service organizations, it is no surprise that we now see performance measurement and effectiveness permeated throughout the nonprofit sector.

In a for-profit context, the shareholders and government are constantly engaged with each other to ensure accountability either through quarterly reports, consumer complaints, or via other agencies such as the Occupational Safety Health and Administration (OSHA), Environmental Protection Agency (EPA), or the U.S. Department of Agriculture. We have seen the swift response to breaches of trust in the for-profit sector in the corporate malfeasance in the 1990's (e.g. Enron, Tyco, WorldCom). In 2002, the U.S. Congress enacted Sarbanes-Oxley to demand greater 
corporate transparency and accountability as well as an increase of performance expectations in an effort to curtail corporate corruption.

Conversely, nonprofits can go for many years under the radar without any indication of mismanagement or wrongdoing. Only in the past decade or so has attention been given to reforming nonprofits. The most recent examples are the Nonprofit Integrity Act of California in 2004 and the Nonprofit Revitalization Act instituted in New York in 2013. Both pieces of legislation were intended to increase transparency and accountability in the charitable sector by requiring organizations to adopt and implement specific processes and policies. In a sense, the new legislation could be considered negative accountability, a mechanism to show lack of performance by highlighting breaches in fiduciary duties when reporting activities in the annual 990 tax return (Swords, 1997).

\section{Performance as Ownership}

In the nonprofit sector, the term "ownership" is a foreign term. However, as foreign as the term may be, ownership is an important concept that intersects with accountability and performance when discussing governance. There is a large body of literature related to corporate and nonprofit board governance as ownership based in economic, political, and sociological theories, with a focus on for-profit theories around control, ownership, and wealth creation (Coule, 2015; Forbes \& Milliken, 1998). As such, ownership is used in this study as a means to show how accountability begins with those who have the most "ownership" of an organization as discussed by nonprofit scholars (Carver in Kearns, 1998; Frumkin \& Galaskiewicz, 2004; Renz, 2004). In other 
words, those who have a responsibility for and who make decisions on behalf of the organization itself are expected to perform their responsibilities.

According to Renz (2004) a board of directors is a structure with which the activity of governance takes place. Nearly all formalized organizations have structures in place where governance activities occur. In for profit corporations, owners are typically the individuals who serve on the board of directors or who are stockholders (shareholders) that have decision-making authority on behalf of the organization. Board members can be shareholders, executives, or even founders who have a common material, or financial, interest in organizational performance (i.e. maximizing profits). As such, it is clear that for profit boards and shareholders are the owners.

For nonprofit organizations, ownership cannot be defined solely by who financially benefits based on the nondistribution constraint as developed by Hansmann (1980). The nondistribution constraint explains that nonprofits do not distribute earnings in a manner that financially benefits an individual, but rather their earnings benefit society as a whole through its "output" (i.e. mission). Similar to for-profit corporations, nonprofit corporations have boards of directors and executives who are given authority to make decisions about organizational resources. It is within this structure that nonprofit boards are held accountable for their performance as they make decisions that affect the overall performance of an organization. Therefore, one might say that boards are in fact a type of "owner" since their decisions impact fulfillment of the mission, organizational performance, and accountability. Using this line of thought for this study, nonprofit leaders are the owners. This is primarily because they have the most decision-making authority and, by default, function as the most likely legal accountability mechanism. 


\section{Role Ambiguity and Governance}

Nonprofit leaders are the individuals who are collectively held legally responsible for how organizational resources are used. These leaders include board members and executives who make decisions about how best to use organizational resources in order to fulfill a tax-exempt mission. Together, they work to accomplish goals and fulfill the mission of the organization in complementary ways: Board members meet broader governance needs by ensuring that the organization has the appropriate resources in place that executives then use in the management of the day-to-day operations.

Renz (2010) sums up the scholarly and practitioner literature related to what board members are responsible for with regards to governance and oversight functions as presented in Table 5.1. However, it is important to note that not all of the recommended functions are tied to the fiduciary duties of care, loyalty, and obedience. For example, although it may be helpful for boards to engage with constituents, technically they are not legally responsible for this specific activity. The duties that are not legal ones have been identified by the researcher and are italicized.

Table 5.1

Prescribed Board Responsibilities Related to Fiduciary Duties

$\begin{array}{ll}\text { Prescribed Board Responsibility } & \text { Addressed in Fiduciary Duties } \\ \text { To lead the organization } & \text { No } \\ \text { Establish policy } & \text { Yes } \\ \text { Secure essential resources } & \text { Yes } \\ \text { Ensure effective resource use } & \text { Yes } \\ \text { Lead and manage the chief executive } & \text { Yes } \\ \text { Engage with constituents } & \text { No } \\ \text { Ensure and enable accountability } & \text { Yes } \\ \text { Assess board effectiveness } & \text { No }\end{array}$

Note. Prescribed board responsibilities reprinted from Nonprofit Leadership and Management, Renz (2010) p. 131-134. 
Given the wide variety of expectations for board members to fulfill, Wright and Millesen (2008) explore the idea of how nonprofit board role ambiguity affects organizational performance. Their study, which surveyed 447 executive directors and 249 board members, suggested that when board members do not have a clear sense of their role, ambiguity occurs (Wright \& Millesen, 2008). Their study also suggested that "board members often think they understand their roles, even when the chief executives do not [think that boards understand their own roles]" (Wright \& Millesen, 2008, p. 330).

The sense of ambiguity was also evident in a study by Doherty and Hoye (2011) that focused on nonprofit sports organizations. Their study builds on previous research that suggested board members are faced with conflicting expectations, which may contribute to ambiguity or a lack of understanding of what their roles entail (Doherty \& Hoye, 2011). Although the authors acknowledged the multi-dimensional nature of gauging board performance in that each organizational context has underlying dynamics, they found that “...the significant association between role ambiguity and board member performance warrants attention to individuals' degree of understanding of their responsibilities" in a nonprofit context (Doherty \& Hoye, 2011, p. 120).

This ambiguity points to a greater problem in nonprofit leaders' inability to perform their fiduciary responsibilities. Miller (2002), who interviewed 58 board members to learn about how boards perform their monitoring function, found that "although board members clearly recognized their fiduciary responsibility to oversee the organizations financial picture, many had no idea how to execute this function" (p. 441). This suggests that not only is there ambiguity about what their roles are, but also ambiguity exists about how to carry out their duties. Therefore, the application of 
knowledge impacts performance. But, how might ambiguity affect board members and executives differently? The following provides a brief overview of what we know about nonprofit leader performance at the board and executive levels.

\section{What We Know About Nonprofit Leaders}

The level of engagement is typically the dividing line between board members and executives. Boards maintain oversight of the entire organization at a broader, more strategic level, whereas executives are responsible to manage the day-to-day operations and support the board with information and guidance. Despite the differences, all nonprofit leader responsibilities are founded in the fiduciary duties of care, loyalty, and obedience of which they are legally accountable to the state and federal regulators. What this means is that the fiduciary duties are the basis for accountability and are related to overall performance since the duties are connected to the use of organizational resources (financial, human, physical, and intellectual) in fulfilling the mission.

Boards. Some scholars have attributed composition of the board as a predictor of organizational performance that includes demographics such as age, gender, and ethnicity as well as professional and educational background (Bradshaw, et al., 1992; Herman \& Renz, 2000; 2006; Jackson \& Holland, 1998). Brown (2007) suggests that having "highly capable board members should coincide with better overall board performance" (p. 306). Given the variety of skills and backgrounds that board members may bring to the table, there is no consensus as to what matters most, again because of the contextual nature of nonprofits. Although it might be helpful to have a sense of what may work in certain contexts, focusing only on the technical features of the board does not provide enough insight into what other factors may impact an organization's ability to perform or meet 
accountability such as geographic location, group dynamics, resources, and even donor relations. Finally, it does not matter if board members are "highly capable" or have the "right" background because the traditional demographics have little to do with fiduciary knowledge.

Holland (2002), who interviewed 169 board members to explore board performance and accountability, highlighted the tension of boards knowing what they are responsible for but that the lack of accountability undermines their effectiveness. This resonates with Miller (2004) who found that in her study of 58 board members some respondents felt that they were accountable only to themselves, because they could not identify other stakeholders to whom they were accountable. Miller (2004) also found that although board members had a very good understanding of their fiduciary responsibilities, what they did not understand how to actually execute or perform their fiduciary function. Given the gap between knowledge and application (as presented in chapter three), inherent challenges exist that may prevent board members from fulfilling their ownership role and meeting not only legal accountability demands, but also in performing their governance duties effectively.

Executives. Although board members are often thought of as the primary governing body, in truth, they operate in tandem with the most senior executive. Even though both board members and executives are held accountable for organizational oversight, executives have different ideas than board members when it comes to what matters for organizational performance. Some research shows that executives often rate board performance much lower than board members rate their own performance (BoardSource, 2017; Bradshaw, et al., 1992; Brown, 2007; Brudney \& Murray, 1998; 
Heimovics \& Herman, 1999; Herman \& Renz, 2000; 2008, Stanford, 2017). Yet, referring back to Miller's study (2004) of 58 board members, for the most part, board members deferred to the chief executive with regards to oversight, bestowing a great deal of trust to the chief executive by the board. So, although the executive feels that their boards are low performers, it is the executive that is relied upon by the board. So, one might question... is performance is a reflection of the executive? In the same vein, Holland (2002) offered that, "even when the nonprofit board addresses accountability, it seems to focus attention on the executive, seldom on the board itself” (p. 412).

BoardSource (2017) and Stanford (2017) have been conducting longitudinal studies for the past few decades of more than 4,000 board members and executives across the nation. These studies provide some insight into the differences between board member and executive perceptions of organizational performance and each other. BoardSource (2017) reported that overwhelmingly both the chief executives and the board members agree that the board has an impact on organizational performance, particularly in knowledge of their roles and responsibilities. Eighty percent of executives and $73 \%$ of board chairs believed that understanding roles and responsibilities has a positive impact on organizational performance (BoardSource, 2017, p. 46).

In contrast however, understanding roles and responsibilities was found to have a weak relationship between perception of board impact on organizational performance by both executives and board chairs; Executives ranked understanding roles and responsibilities as the fifth most important and board chairs ranked it fourth (out of five) (BoardSource, 2017, p. 45). Furthermore, the report (BoardSource, 2017) showed that while executives emphasize positive board culture, the board chairs emphasize the 
board's functional roles as the basis for performance. In terms of specific fiduciary duty performance, both the executives and the board chairs agreed that board preparation for meetings is lacking, which is a function of the performance of the duty of care that focuses on active participation and engagement of the governing body (BoardSource, 2017).

Fishman, Schwarz, and Mayer (2015) made a distinction between having the appropriate governance structures and practices in place and actually engaging in those practices for the oversight and management of nonprofits. If engagement was measured in terms of satisfaction, most nonprofits would be in a sorry state. The Stanford Survey (2017) reported that only 55\% of the executives and 57\% of the board members who responded were satisfied or very satisfied with the way their organization is managed day-to-day (p. 45). Because managing the day-to-day is typically the responsibility of the executive (unless the organization is run by a working board where all board members manage the day-today operations) these results are interesting given that most executives typically score themselves higher than their boards.

The dissatisfaction could be related to the finding that just over half of the executives and board members are satisfied or very satisfied with the overall performance and significant impact of the organization (Stanford, 2017). If the nonprofit leaders as a whole are dissatisfied in the day-to-day operations, which is the executive responsibility, this might point to both the executives and board members inability to perform their duty of care. An aspect of the duty of care focuses on the board's responsibility to review the performance of the chief executive. 


\section{Application of Knowledge Results}

Jackson and Holland (1998) concluded, "if nonprofit boards are to fulfill their fiduciary and leadership responsibilities, boards must be able to assess the effectiveness of their performance" (p. 159). What this study provides is a means to assess how nonprofit leaders fulfill their fiduciary responsibilities in the performance of their governance activities. The following presents the results of how nonprofit leaders apply their fiduciary knowledge in the performance of their governance duties, as a means to fulfill accountability to whom. In terms of measuring performance, the study focuses on how frequently nonprofit leaders carry out their fiduciary duties during their governance activities, specifically focused on the duties of care, loyalty, and obedience. First, the questions used in the survey are presented then reliability where appropriate, followed by the results by all roles.

\section{Survey Questions}

Respondents were given a four-point Likert scale option for answering. Because of the use of skip logic in the survey and the questions were organized, executives were given the option to answer "disagree to agree" and board members were given "never to always." However, to get at application, all questions began with the stem, "as a board member I..." or "as an executive I...". The questions were developed to align with the duties of care, loyalty, and obedience constructs and are provided in Table 5.2. 
Table 5.2

List of Survey Questions Categorized by Duty and Measurement

Fiduciary Duty
Care:
Engagement,
Attention,
Informed Process
of Decision-
Making

Loyalty:

Procedural

Aspects of

Transactions and

Self Interest

Obedience:

Legal

Compliance
"As a Board Member, I..."

4-point Likert: Never to Always

- Review materials in advance of the board meeting

- Pay attention to the organization's resources (e.g. financial, physical, and human)

- Exercise independent judgment (i.e. comparing, evaluating, and considering possible outcomes and possibilities)

- Frequently review the organization's finances and financial policies

- Attend board meetings

- Am aware of the executive's performance

- Participate in the review, discussion, and/or approval of financial policies (e.g. annual budget, audit)

- Make decisions that are in the best interest of the organization

- Disclose conflicts of interest

- Avoid the use of organizational resources/connections for personal gain

- Maintain confidentiality of sensitive organizational information

- Pay attention to how the organization uses its resources (financial/physical/human) to fulfill its mission

- Understand the Bylaws

- Refer to the organization's internal policies and procedures when needed

- Refer to the mission statement when discussing potential programs and services

- Consider how new and existing programs support our mission
"As an Executive, I..."

4-point Likert: Disagree to Agree

- Exercise Independent Judgment

- Pay attention to how the organization's programs and activities fulfill its mission.
- Disclose conflicts of interest

- Refer to the mission statement when discussing potential programs and services

- Pay attention to how the organization uses its resources (financial/physical/human) to fulfill its mission

- Read the bylaws 


\section{Reliability}

Boards. A four-point Likert option for board member responses was given (Never, Sometimes, Most of the Time, and Always) to understand the frequency with which knowledge of the fiduciary duties was applied in the performance of governance duties, which allowed for Cronbach's alpha to test reliability. The duty of care scale consisted of eight items and was found to be very reliable $(\alpha=.88)$ with each item in the same direction. The duty of loyalty scale consisted of four items and was found to be moderately reliable with a Cronbach's alpha of $.514(\alpha=.51)$ with each item in the same direction. The duty of obedience scale consisted of five items and was found to be very reliable with a Cronbach's alpha of .794 $(\alpha=.79)$ with each item in the same direction. Table 5.3 presents descriptive data for the application of each fiduciary duty for board members used for Cronbach's alpha analysis. 
Table 5.3

Descriptive Data for Frequency of Application of Duty of Care for Board Members

Std.

\begin{tabular}{ccccccc} 
Duty Questions & N & Mean & Median & Dev. & Min & Max \\
\hline Care & & & & & &
\end{tabular}

Pay attention to how the organization's activities (e.g. programs and services) fulfill its mission

Review materials in advance of the board meeting

$\begin{array}{llllll}96 & 3.7 & 4 & .509 & 1 & 4 \\ 96 & 3.4 & 4 & .723 & 1 & 4 \\ 96 & 3.5 & 4 & .665 & 1 & 4 \\ & & & & & \\ 96 & 3.8 & 4 & .543 & 2 & 4 \\ & & & & & \\ 96 & 3.4 & 4 & .837 & 1 & 4 \\ 96 & 3.7 & 4 & .513 & 2 & 4 \\ 93 & 3.4 & 3 & .616 & 1 & 4 \\ 93 & 3.7 & 4 & .592 & 1 & 4\end{array}$

4

Pay attention to the organization's resources (e.g. financial, physical, and human)

Exercise independent judgment (i.e. comparing, evaluating, and considering possible outcomes and possibilities)

Frequently review the organization's finances and financial policies Attend board meetings

Am aware of the executive's performance Participate in the review, discussion, and/or approval of financial policies (e.g. annual budget, audit)

$$
\text { Loyalty }
$$

Make decisions that are in the best interest of the organization

Disclose conflict of interest

Avoid the use of organizational resources/connections for personal gain Maintain confidentiality of sensitive organizational information

Obedience

Pay attention to how the organization uses its resources (e.g. financial, physical, and human) to fulfill its mission

Understand the bylaws

Refer to the organization's internal policies and procedures when needed

91

92

3.9

4

.360

.370

93

4

3.9

4

92

3.9

4

4

.305

2

4

Refer to the mission statement when discussing potential programs and services Consider how new and existing programs support our mission

\begin{tabular}{cccccc}
96 & 3.7 & 4 & .567 & 1 & 4 \\
96 & 3.1 & 3 & .796 & 1 & 4 \\
96 & 3 & 3 & .917 & 1 & 4 \\
96 & 3.3 & 4 & .874 & 1 & 4 \\
93 & 3.7 & 4 & .551 & 1 & 4 \\
\hline
\end{tabular}


Executives. Because of the small number of items included in the executive's application of the duties, Cronbach's alpha was not deemed fit. Table 5.4 presents the descriptive data for the fiduciary duties for executives.

Table 5.4

Descriptive Data for Frequency of Application of Fiduciary Duties for Executives

Std.

Duty Questions

N Mean Median Dev.

Dev.

Min $\quad$ Max Care

Exercise independent judgment $82 \quad 3.9$

4 .241

3 4

Pay attention to how the organization's programs and activities fulfill its mission Loyalty

Disclose conflict of interest 824

$4 \quad 4$

$4 \quad .268$ 2 4

$82 \quad 3.9$

4

.404

1
4

Obedience

Pay attention to how the organization uses its resources (e.g. financial, physical, and human) to fulfill its mission

Read the bylaws

$\begin{array}{ll}82 & 3.9\end{array}$

$81 \quad 3.9$

4

4

.287

.494

Refer to the mission statement when discussing potential programs and services

82

3.9

4

.500

1

\section{Application Results}

By role. Board members and executives were asked about how frequently they fulfilled the fiduciary duties in the performance of their governance responsibilities using a four-point Likert scale. Board members were given never, sometimes, most of the time, and always while executives were given disagree, somewhat disagree, somewhat agree, and agree. The results for board members are presented in Table 5.5 and Table 5.6 for executives.

Board members applied their fiduciary knowledge to the duties of care, loyalty, and obedience most of the time or always (Care: $N=96, M=3.6, S D=.473$; Loyalty: $N$ $=93, M=3.9, S D=.370$; Obedience: $N=96, M=3.3, S D=.552$ ). Executives somewhat 
agree or agree that they perform their fiduciary duties $(N=82$, Care: $M=7.9, S D=.385$;

Loyalty: $N=82, M=3.9, S D=.404$; Obedience: $N=82, M=11.6, S D=1.074)$.

Table 5.5

Descriptive Data for Frequency of Application of Duties of Care, Loyalty, and Obedience for the Board

\begin{tabular}{lcccccc}
\multicolumn{1}{c}{ Application of Duty } & $\mathrm{N}$ & Mean & Median & Std. Dev. & Min. & Max. \\
\hline Care (8 questions) & 96 & 3.6 & 3.8 & .473 & 1.6 & 4 \\
Loyalty (4 questions) & 93 & 3.9 & 4.0 & .370 & 1.2 & 4 \\
Obedience (3 questions) & 96 & 3.3 & 3.4 & .552 & 1.4 & 4 \\
\hline
\end{tabular}

Note. Questions were 4 Point Likert scale options of Never to Always.

Table 5.6

Descriptive Data for Frequency of Application of Duties of Care, Loyalty, and Obedience for Executives

\begin{tabular}{lcccccc}
\multicolumn{1}{c}{ Application of Duty } & $\mathrm{N}$ & Mean & Median & Std. Dev. & Min. & Max. \\
\hline Care (2 questions) & 82 & 7.9 & 8 & .385 & 6 & 8 \\
Loyalty (1 question) & 82 & 3.9 & 4 & .404 & 1 & 4 \\
Obedience (3 questions) & 82 & 11.6 & 12 & 1.074 & 5 & 12 \\
\hline
\end{tabular}

Note. Questions were 4 Point Likert scale options of Disagree to Agree.

\section{Application of Duties and Actual Knowledge}

Pearson's r correlation. Using knowledge data from chapter three, a Pearson $r$ correlation was performed to explore any relationship with the frequency of application of duties of care, loyalty, and obedience by those who were assessed as having a passing score of fiduciary knowledge (see chapter three). The results show that actual knowledge is not correlated with nonprofit leader application of any of the fiduciary duties (care: $r=$ $.076, p=. .450$, loyalty: $r=.001, p=.991$; obedience: $r=.117, p=.247)$ in the performance of fiduciary responsibilities as presented in Table 5.7. Further results indicate that application of care, loyalty, and obedience are moderately correlated with each other (care and loyalty: $r=.665, p=.000$; care and obedience: $r=. .622, p=.000$; obedience and loyalty: $r=.554, p=.000)$.

Table 5.7 
Summary of Pearson's r Correlation for Nonprofit Leaders with Passing Fiduciary Knowledge and the Application of the Duties of Care, Loyalty, and Obedience

\begin{tabular}{|c|c|c|c|c|c|}
\hline & & $\begin{array}{c}\text { Actual } \\
\text { Knowledge }\end{array}$ & $\begin{array}{c}\text { Application } \\
\text { of Care }\end{array}$ & $\begin{array}{c}\text { Application of } \\
\text { Loyalty }\end{array}$ & $\begin{array}{l}\text { Application } \\
\text { of Obedience }\end{array}$ \\
\hline \multirow{4}{*}{$\begin{array}{l}\text { Actual } \\
\text { Knowledge }\end{array}$} & Pearson & 1 & .076 & .001 & .117 \\
\hline & Correlation & & & & \\
\hline & Sig. (2-tailed) & & .450 & .991 & .247 \\
\hline & $\mathrm{N}$ & 100 & 100 & 100 & 100 \\
\hline \multirow{4}{*}{$\begin{array}{l}\text { Application of } \\
\text { Care }\end{array}$} & Pearson & .076 & 1 & $.665^{* *}$ & $.622^{* *}$ \\
\hline & Correlation & & & & \\
\hline & Sig. (2-tailed) & .450 & & .000 & .000 \\
\hline & $\mathrm{N}$ & 100 & 186 & 186 & 186 \\
\hline \multirow{4}{*}{$\begin{array}{l}\text { Application of } \\
\text { Loyalty }\end{array}$} & Pearson & .001 & $.665^{* *}$ & 1 & $.544^{* *}$ \\
\hline & Correlation & & & & \\
\hline & Sig. (2-tailed) & .991 & .000 & & .000 \\
\hline & $\mathrm{N}$ & 100 & 186 & 186 & 186 \\
\hline \multirow{4}{*}{$\begin{array}{l}\text { Application of } \\
\text { Obedience }\end{array}$} & Pearson & .117 & $.622^{* *}$ & $.544^{* *}$ & 1 \\
\hline & Correlation & & & & \\
\hline & Sig. (2-tailed) & .247 & .000 & .000 & \\
\hline & $\mathrm{N}$ & 100 & 186 & 186 & 186 \\
\hline
\end{tabular}

Note. $* *$ Correlation is significant at the 0.01 level (2-tailed). Passing score based on $70 \%$, 14 out of 19 possible points.

\section{Application of Duties and Actual Knowledge}

Figure 5.3 illustrates the comparison of the frequency with which nonprofit leaders say they apply their fiduciary knowledge and their actual knowledge of specific aspects of the fiduciary duties for board members and Figure 5.4 presents the comparison the frequency with which nonprofit leaders say they apply their fiduciary knowledge and their actual knowledge of specific aspects of the fiduciary duties for executives.

Familiarity of each duty is presented by the means based on a 4-point Likert scale (Not at All Familiar, Slightly Familiar, Moderately Familiar, Very Familiar) and the actual knowledge score is based on the percentage who received a passing score of at least $70 \%$ for the 11 legal responsibilities and the eight bylaws questions. Overall, For board 
members and the duty of care, \%, loyalty, and obedience received a passing score For the executives received a passing score for actual knowledge.

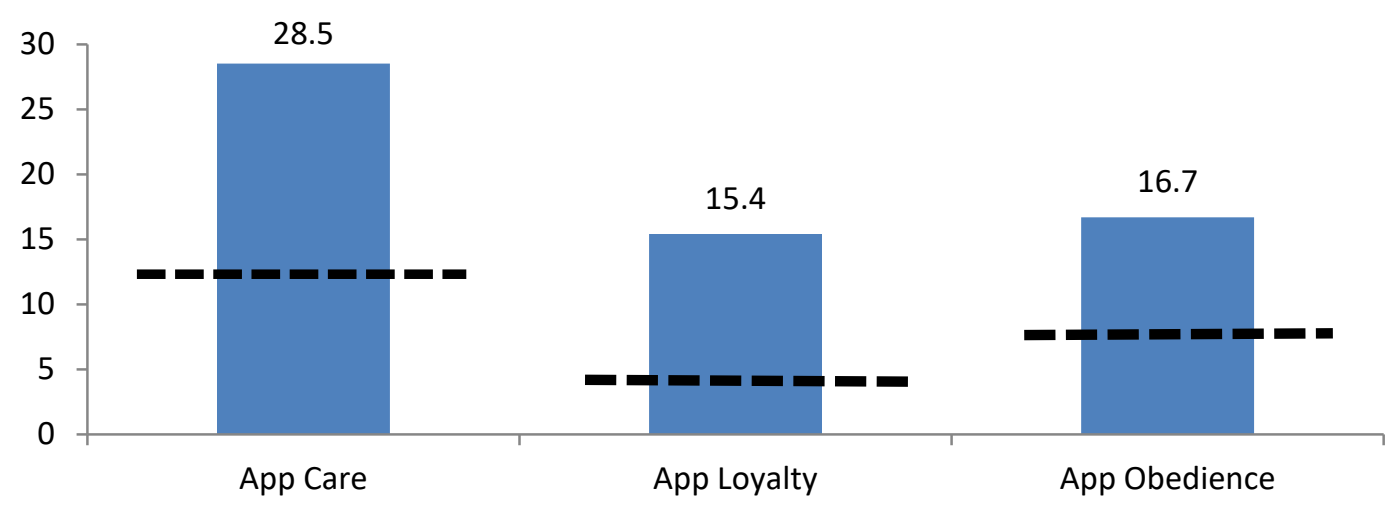

Figure 5.3. Means of application of duty of care, loyalty, and obedience compared to the percentage of actual knowledge of overall fiduciary care, loyalty, and obedience for board members.

Note: The dotted line represents the percentage (41\%) of board members (care $N=96$, loyalty, $N=93$, and obedience, $N=96$ ) who received a passing score of $70 \%$ or better for the 19 questions about legal responsibilities and bylaws. Percentage for plotting was determined by calculating the proportion of $41 \%$ with each duty maximum mean (care: $32=13.12$, loyalty: $16=6.56$, and obedience: $20=8.2$ ).

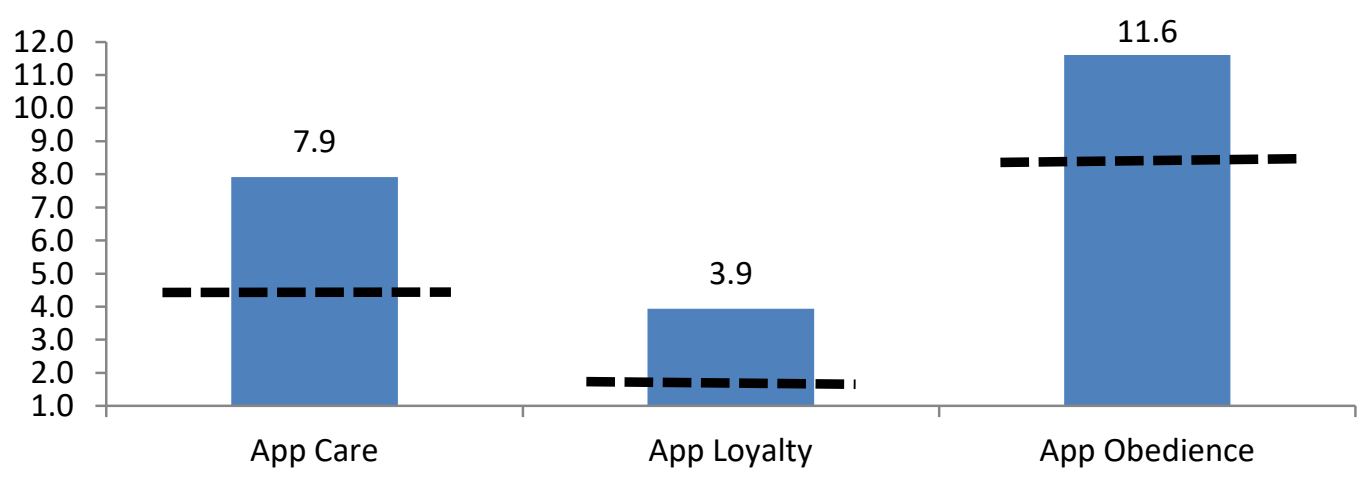

Figure 5.4. Means of application of duty of care, loyalty, and obedience compared to the percentage of actual knowledge of overall fiduciary care, loyalty, and obedience for executives.

Note: The dotted line represents the overall percentage $(70 \%)$ of executives (care $N=82$, loyalty, $N=82$, and obedience, $N=82$ ) who received a passing score of $70 \%$ or better for the 19 questions about legal responsibilities and bylaws. Percentage for plotting was determined by calculating the proportion of $70 \%$ with each duty maximum mean (care: 8 $=5.6$, loyalty: $4=2.8$, and obedience: $12=8.4$ ). 


\section{Discussion}

This chapter presents the results of frequency with which nonprofit leaders apply their knowledge in the performance of their fiduciary responsibilities to demonstrate legal accountability. The study highlights the need for a greater awareness of fiduciary responsibility knowledge. What follows is a discussion about the gaps between application of fiduciary knowledge and actual knowledge, first by the executives then by the board members.

\section{The Gaps: Application of Duties and Actual Knowledge}

Executives. For the executives, they somewhat agreed or agreed that they apply their fiduciary knowledge in the performance of their governance duties of care $(N=82$, $M=7.9)$, loyalty $(N=82, M=3.9)$, and obedience $(N=82, M=11.6)$. In terms of actual knowledge, overall $70 \%$ of executives surveyed received a passing score for their actual knowledge of their legal responsibilities. Overall, these results support a sense of ownership and the executive's ability to satisfy legal accountability. But, the results about specific aspects of each duty may tell a different story.

Duty of care. The duty of care focuses on paying attention and being engaged by making informed decisions. Regarding individual questions in the duty of care construct, we see that executives agreed they exercise independent judgment $(N=82, M=3.9)$ and all of the executives pay attention to the how the organization's programs and activities fulfill its mission ( $N=82, \mathrm{M}=4.0)$. These results are not surprising given that executives play a critical role in governance by monitoring the day-to-day operations of the organization. Likewise, because most of their work informs the board, they develop program strategy usually in isolation or with other senior staff if the organization is large 
enough. This process requires that they make decisions based on their own best judgment.

Duty of loyalty. The duty of loyalty focuses on conflict of interest and putting the interests of the organization above the interests of the individual. Executives nearly always agreed they disclose conflict of interest $(N=82, M=3.9)$. This result is not surprising given that as the chief executive they are under more scrutiny than the board. Because they are in the community as the face of the organization, they may have a greater awareness of how their actions impact those they serve.

Duty of obedience. The duty of obedience focuses on compliance and ensuring that the mission is fulfilled. Again, we see that nearly all of the executives agreed that they apply their fiduciary knowledge in the performance of their governance activities by paying attention to how the organization uses its resources to fulfill the organization's mission ( $N=82, M=3.9)$, reading the bylaws $(N=81, M=3.9)$, and referring to the mission statement when discussing potential programs and services $(N=82, M=3.9)$. Again, these results are not surprising given that most of the day-to-day decisions that executives make are related to the organization's programs and services and that they bylaws are an important governance document.

However, only $68 \%$ of the executives correctly identified that executive staff roles and responsibilities were included in the bylaws based on the results of chapter three. This is surprising given that the bylaws outline overall authority of the executive related to signing contracts, finances, and bank access. For executives, it would be imperative to know how much formal authority they have and how their relationship with the board is legally defined in the performance of their fiduciary duties. 
Boards. For board members, they agreed that they apply their fiduciary knowledge in the performance of their governance duties of care $(N=96, M=3.6)$, loyalty $(N=93, M=3.9)$, and obedience $(N=96, M=3.3)$. In terms of actual knowledge, overall $41 \%$ of board members surveyed received a passing score for their actual knowledge of their legal responsibilities. Overall, these results support a sense of ownership and the executive's ability to satisfy legal accountability.

Something interesting to note with regards to the board results is that they scored lower than the executives in terms of applying their fiduciary knowledge in the performance of the duties of care and obedience. These results build on previous studies that note executives typically score themselves higher than their boards (BoardSource, 2017; Stanford, 2017).

Duty of care. The duty of care focuses on paying attention to the work and being engaged by making informed decisions. Board members indicated that they apply their fiduciary knowledge in the performance of their responsibilities most frequently when exercising independent judgment (i.e. comparing, evaluating, and considering possible outcomes and possibilities $)(N=96, M=3.8)$ and least frequently in reviewing materials in advance of the board meeting $(N=96, M=3.4)$ and in reviewing the organization's finances and financial policies $(N=96, M=3.4)$.

It is not surprising to find that preparation for board meetings is lacking given the results of a national survey (BoardSource, 2017) that reported both the executives and the board chairs agreed that preparation for board meetings is lacking (p. 49). Additionally, based on results from chapter three only $50 \%$ of the board members correctly identified regular attendance of board meetings as a legal responsibility and only $34 \%$ correctly 
identified reviewing board meeting materials prior to the board meeting as a legal responsibility. What this means is that board members may not take as much ownership in the actual decision making process as they need to be, because they need to be more informed about the organization's resources. This would indicate that they are not fulfilling their duty of care.

Duty of loyalty. The duty of loyalty focuses on conflict of interest and putting the interests of the organization above the interests of the individual. Board members indicated that they apply their fiduciary knowledge in the performance of their responsibilities nearly always in all areas of the duty of loyalty. These results are surprising given that board members assessed themselves with such a high degree of frequency when only $65 \%$ of the board members correctly identified the need to use independent judgment when making decisions about organizational resources as a legal responsibility as presented in chapter three. This would point to role ambiguity and a potential breach of duty of loyalty if board members are swayed by influential stakeholders such as funders, the executive, or dominant board personalities.

Duty of obedience. The duty of obedience focuses on compliance and ensuring that the mission is fulfilled. Board members indicated that they apply their fiduciary knowledge in the performance of their responsibilities most frequently when paying attention to how the organization uses its resources $(N=96, M=3.7)$ and when considering how new and existing programs support the organization's mission $(N=93$, $M=3.7)$, but least frequently in understanding bylaws $(N=96, M=3.1)$ and referring to the organization's internal policies and procedures when needed $(N=96, M=3.0)$. These results were surprising given that board members scored very high in their actual 
knowledge of specific aspects of the duty of obedience as presented in chapter three. The bylaws are a critical piece in governance and if bylaws are not read, board members make decisions about organizational resources without knowledge of how the organization itself has decided how it will make decisions. Thus, board members would be in breach of the duty of obedience and not satisfy legal accountability if they do not have knowledge of their organization's bylaws.

\section{Implications}

Holland (2002) sums up nonprofit accountability as "practices and processes of clarifying expectations agreeing on goals and criteria for assessing progress toward them, and the providing information by which to assess performance" (p. 426). My study supports not only clarifying legal expectations, but the development of an assessment tool with which to assess legal aspects of governance, bounded by the fiduciary duties of care, loyalty, and obedience. Although there is no scholarly consensus as to what performance measurements are the most useful, I offer that we must continue to dig deeper into how boards actually behave to establish more generalizeable data. As nonprofit leaders improve their performance, by default they will improve organizational effectiveness and accountability.

This study highlights the need for greater awareness of fiduciary knowledge in the performance of governance duties amongst nonprofit leaders. Overall, nonprofit leaders can use these results to identify areas that may impact board members' and executives' performance of their fiduciary duties. As such, my results contribute to the development of nonprofit leader trainings that frequent board service may negatively impact 
performance and that additional research needs to be done to better understand the discrepancies between board and executive application of knowledge.

The results of this study can be used to significantly impact the area of performance and effectiveness. Although I used the concepts slightly different than the literature does, there is something about nonprofit leaders being able to perform their duties with the appropriate fiduciary knowledge. As indicated in chapter three, because the fiduciary duties of care, loyalty, and obedience are expectations for all nonprofit leaders, regardless of organizational size, purpose, or location, they can be used as a basis to develop a standardized process that assesses a nonprofit leader's readiness for service. In turn, the assessment can be used during the orientation process to ensure that their board is made up of leaders that know their legal responsibilities. Furthermore, an assessment would help organizations use their resources to address specific gaps to deter mismanagement and wrong doing, whether negligent or willful.

\section{Future Research}

This chapter reveals a gap between how frequently nonprofit leaders apply their fiduciary knowledge and their actual knowledge. While this study is exploratory, in that it pilots an assessment tool and seeks to establish baseline data for future research, it highlights the need for greater awareness of fiduciary responsibility knowledge and competence. Additional empirical use of the assessment tool developed for this study will add not only to the nonprofit literature but also to the nonprofit law literature.

Additionally, future qualitative research may help to uncover the underlying reasons why the level of knowledge varies amongst nonprofit leaders. 
Furthermore, there is a need for research that explores individual nonprofit leaders as the unit of analysis, rather than the board as a whole. Specifically, my study builds on the idea that individual nonprofit leader knowledge is important for organizational performance in by addressing legal accountability as a means to dispel role ambiguity and to encourage ownership and solid decision-making grounded in the fiduciary responsibilities. 


\section{CHAPTER 6: CONCLUSION}

Collectively, this dissertation addresses the issue of accountability and nonprofit governance by focusing on legal accountability. Separately, each article explores the means by which nonprofit leaders satisfy the different facets of legal accountability as they relate to the fiduciary duties of care, loyalty, and obedience.

The study began by setting the stage and describing how over time, nonprofit governance has evolved. With increased competition for resources and demand for services, nonprofit leaders are being asked to fill additional responsibilities that go beyond the basic fiduciary duties. Nonprofit leaders of today are expected to engage at greater levels than their predecessors as highlighted by the tensions of the voluntary nature of board service, the need for professionalization, and the need to meet the accountability demands of multiple stakeholders. Using an accountability framework that focuses on what, how, and to whom (Ebrahim, 2010), this study establishes that what nonprofit leaders are legally accountable for is knowledge of their fiduciary duties, how they meet legal accountability by accessing appropriate sources to learn about their fiduciary duties, and to whom they are legally accountable to is the regulators by demonstrating application of their fiduciary knowledge in the performance of their governance duties.

\section{Knowledge}

The first study focused on what nonprofit leaders were accountable for: knowledge of their fiduciary duties. In assessing nonprofit leader knowledge of fiduciary duties, the majority agreed that they were very familiar. However, when tested for actual knowledge, only $41 \%$ of board members and $70 \%$ of executives passed the test. When 
analyzed by the number of boards served, $56 \%$ of nonprofit leaders who have served on one to four boards and $71 \%$ of those who have served on five or more boards passed. Although nonprofit leaders believe they understand their fiduciary responsibilities, in reality they do not, suggesting that they may be stretched too thin. Because nonprofit leaders are asked to fill multiple roles, they lack the knowledge of their basic responsibility: to oversee organizational resources so that they are used in a manner that fulfills the mission.

When looking at these results through a legal accountability lens, it is glaringly evident that nonprofit leaders cannot demonstrate accountability because they do not understand their basic responsibilities. Without the proper knowledge of what is required nonprofit leaders are at a disadvantage when making important decisions related to how resources will be used to fulfill the mission. If nonprofit leaders lack understanding that, for example, reading materials and making informed decisions is based on the fiduciary duty of care, they may govern in a haphazard manner. Furthermore, this study highlights that nonprofit leaders are unaware that they "don't know that they don't know" given that such a high percentage of respondents scored with a high degree of familiarity and understanding.

\section{Source of Knowledge}

The second study focused on how nonprofit leaders demonstrate legal accountability: accessing appropriate sources to learn about their fiduciary duties. This strand of research was theoretical in that it applied institutionalism in order to explain why nonprofit leaders would want to be informed about their legal responsibilities, specifically in response to isomorphic coercive, mimetic, and normative mechanisms. In 
order to explore what sources nonprofit leaders accessed to learn about their fiduciary duties, best practices were used as socially constructed proxies in the absence of widely accepted standardized assessments.

When looking at the results through a legal accountability lens, nonprofit leaders utilized a variety of best practices available to them both internal and external to the organization, to learn about their legal responsibilities. Despite the availability of formalized internal sources, such as a board manual or orientation, nonprofit leaders accessed informal means the most regardless of role or board service. Thus, nonprofit leaders are learning about their fiduciary responsibilities from other board members or executive directors. However, this knowledge may or may not be accurate. Building on the first study, many nonprofit leaders did not pass the test in their actual knowledge. Therefore, it can be said that bad knowledge is being passed on from leader to leader and from board to board.

In terms of external sources, nonprofit leaders rely most on websites, regardless of role or board service. Rather than relying on more formalized sources such as professional publications or certification and degree programs, nonprofit leaders look to the world wide web, a socially constructed source of knowledge. And, similar to informal means, there is no way of ensuring that the information is credible, legitimate, or truthful.

This study did not measure institutionalist pressures, but the results do suggest some link with best practices and mimetic mechanisms. What is interesting is that most nonprofit organizations behave in a mimetic fashion with the use of the same types of best practices intended to help nonprofit leaders understand the organization and their roles, such as board manuals, board orientations, and educational opportunities. Yet, how 
might isomorphism explain the use of informal means of learning? More research would help to understand this better.

\section{Application of Knowledge}

The third study focused on to whom nonprofit leaders demonstrate legal accountability: the application of fiduciary knowledge in the performance of their governance duties. This strand of research was conceptual in that it applied performance in a non-traditional way. Rather than relying on the usual performance metrics such as organization size, age, board composition and backgrounds, performance was discussed in terms of ownership. In offering nonprofit leaders as owners, legal accountability is demonstrated as they apply fiduciary knowledge in the performance of their governance duties. This strand of research included the idea of role ambiguity and the confusion that nonprofit leaders have about what they are supposed to do in their roles.

When looking at the results through a legal accountability lens, we see similar results as in the first study as nonprofit leaders frequently apply their fiduciary knowledge in the performance of their governance duties. However, given the low levels of actual knowledge, it is evident that nonprofit leaders perform their governance duties based on a lack of understanding of their legal responsibilities. What this means is that although nonprofit leaders may believe that they are engaged in their role, they do not fully understand what that role actually is, pointing to role ambiguity. As "owners", nonprofit leaders are making decisions based on ignorance, which may hinder success.

Furthermore, these results open up the possibility that the traditional measures of performance, such as organizational age, revenue types, board composition and background are less important when it comes to fulfilling the mission. I would offer that 
nonprofit leaders who have an understanding of their basic fiduciary duties are more engaged and therefore have more investment in the performance of the organization. However, more research is needed to explore this.

\section{The "So What?"}

So, how does this dissertation contribute? As a whole, it reveals the gap in what nonprofit leaders believe they know and how they carry out their fiduciary duties based on lack of fiduciary knowledge. Separately, each study highlights the need for awareness, understanding, and performance of fiduciary duties in order to meet legal accountability demands.

The current legal accountability structure is woefully inadequate and for the most part, is non-existent. Enforcement is reactive and when negligence or wrongdoing is suspected, depending on the resources available at the state and federal levels, investigation is minimal. Furthermore, there is no incentive for nonprofit organizations to ensure that their leaders have accurate fiduciary knowledge and an understanding of what their role is and what it is not. Finally, even when nonprofits are found lacking in the performance of their fiduciary duties, they face little to no consequences because of the voluntary nature of nonprofits.

As a consultant I have met with numerous nonprofit leaders who are not familiar with the term "the fiduciary duties", so it is not surprising to learn that many board members and some executives do not get a passing score. And, as a consultant, I have helped several nonprofits regain their tax exempt status after being revoked for lack of knowledge of their fiduciary duties. In all cases, most nonprofit leaders were unaware of 
their responsibilities and they were eager to learn what their responsibilities were in order to avoid future breaches.

This study is relevant to funders, regulators, and nonprofit organizations themselves since they are all interested in the success of nonprofits. This study provides actual data that stakeholders can use to work together in order to strengthen nonprofit governance. Funders could provide resources for trainings and regulators can work with national and state nonprofit associations and coalitions to create standards to assess fiduciary knowledge. Organizations can address the need for qualified board members and executives by ensuring that any person responsible for making decisions about organizational resources understands that it is a legal responsibility, not just a fun hobby.

As much as these ideas have potential for success, the real challenge is the contextual nature of nonprofits. What works for one organization may not work for another. And, given the voluntary nature of board service and the pluralistic aspect of nonprofits, the nonprofit sector has adopted a "come one, come all" mantra which may be sacrificing quality for quantity. However, at the end of the day, when an organization is suspected of wrongdoing, they will be measured against how they went about their governance activities according to the standards outlines in the fiduciary duties of care, loyalty, and obedience. So, although nonprofits come in many different shapes, sizes, and colors, they are all held to the same standard of governance: did they use organizational resources to fulfill the mission and did they go about their decision-making process with the best interest of the organization in mind, not their own. 


\section{The "Now What?"}

So, what's next? As an academic, there are several ways I can move my research forward. Additionally, as a practitioner, I have ideas about how to turn my research into practical, relevant tools for those working in the sector on a daily basis. In both cases, I see opportunities to add to the literature in empirical and applied ways. My plan is to use this dissertation by developing each of the three strands of research into stand-alone submissions for academic and practitioner publications and share the collective data with students, nonprofit organizations, and funders.

\section{Connecting Research to Practice}

With regards to nonprofit academics, some may have experience volunteering for a nonprofit, but very few have worked in a nonprofit. Given the lack of "on the ground" experience, much of their research relies on publicly available data, unless they are fortunate enough to have funding for a study that allows them to engage with nonprofit organizations. What this means is that most people who research nonprofits do not interact with the nonprofit. In fact, their interaction is non-existent, because they rely on data from other sources. While data is helpful in that it points to trends, it is just one dimension of an organization that focuses on the numbers. What it lacks is insight about the people doing the work. This really hit home for me when I attended a workshop about nonprofit governance at one of the premiere nonprofit research conferences. After the presenters shared the results of their studies, they answered questions from the audience. As the question and answer period came to a close, one of the presenters concluded with, "we really don't know what goes on in these boardrooms". If we are to understand those 
who govern nonprofits, we must be where they are: in the boardrooms and in the organizations.

Another reason to "get inside the boardrooms" is to engage and bridge the divide between research and practice. This is particularly true for sharing data and research. Only a small portion of the research on nonprofit organizations is accessible to nonprofit practitioners. Journal publications require subscriptions that are too costly for the majority of nonprofits around the country and based on the results of this study, many do not even access those that are readily available. Furthermore, when studies are completed, researchers are already on to the next study and do not share findings with the participating organizations.

I say all of this with the hope that I use my study as a means to encourage fellow researchers to interact with the organizations they wish to study and for practitioners to invite researchers into their organizations.

\section{Challenges and Opportunities}

Over the years, I have seen many challenges and opportunities in my travels in the nonprofit sector. It seems that the biggest challenge I have witnessed is the relationship between the board and the executive. Boards do not understand or appreciate the executive and the executive looks at their board as a burden. And, over the years, I have found that the executives and boards who do work well together understand their individual roles and responsibilities. This leads me to focus on the fiduciary duties as a critical piece in leading and managing nonprofit organizations. The duties provide guidelines for both boards and executives that when followed, strengthen leadership and eases tension. 
Another challenge in the sector is the mindset of quantity, not quality. The fact is some people will join boards without any intention of doing the work and organizations accept these "dead weights" because they need to fill board vacancies (and sometimes the executive position). Yet, in satisfying quotas, organizations find that they spend the majority of their time trying to get board members to do their jobs and to engage which negatively impacts the mission. There is an opportunity for organizations to set the bar high for the requirements for board service and the executive. When expectations are outlined up front, performance will follow. When board members and executives know what their legal responsibilities are, they will be more inclined to carry out their roles in an intentional manner. Furthermore, when potential board members and executives know what they are legally responsible for, those who do not want to commit to the work are weeded out, saving the organization from troubles later on.

I am a practitioner at heart, having spent more than 20 years as a professional in the nonprofit sector. And, because of my positionality, I can see how this study could make an impact. Because of my position as a practitioner, and now as an academic, my goal is to be a bridge to connect academics with practitioners to address the critical issues in a way that provides practical use. As such, I am committed to sharing the findings with nonprofits and using the assessment tool further.

In my work as a consultant I have the opportunity to bring organizations back to the basics, their legal responsibilities, as a means to get everyone on the same page that asks: Why are they there and what are they required to do? As I continue to use the survey, my hope is that it can become a standardized assessment that nonprofits can use in their on-boarding and orientation process to ensure that their leaders are making 
decisions based on their legal responsibilities. My dream would be to work with regulators to create a standardized process that includes best practices and an assessment that eventually could be a requirement for board service.

\section{Final Thoughts}

In many ways this study is the pinnacle of more than 20 years of practice. It has been a scholarly and personal journey that has changed me in many ways. What has not changed, is my passion and belief in the nonprofit sector and my belief that organizations who thrive are those who focus on good governance.

The $40^{\text {th }}$ President of the United States of America, Ronald Reagan, was quoted as saying, "Trust, but verify". For me, I hope that we can not only trust nonprofit leaders to be accountable for their performance, but also that we can verify that they are fulfilling their fiduciary duties. Whether through standardized assessment, trainings or resources, nonprofit leaders have the opportunity to access the right knowledge to use at the right time so that they are positioned to support their organizations to carry out their missions for years to come. 


\section{References}

Alliance for Nonprofit Management Government Affinity Group Leadership SelfAssessment and Preparation for Officers and Committee Chairs Personal copy received November, 2017.

Andersson, F. O., \& Renz, D. O. (2009, November). Relationships between board characteristics and nonprofit performance in donative and commercial nonprofit organizations: Preliminary work on a longitudinal study. In annual ARNOVA Research Conference, 19-21.

Arnsberger, P., Ludlum, M., Riley, M., \& Stanton Winter, M. (2005). Statistics of Income Bulletin History of the Tax Exempt Sector: An SOI perspective. Retrieved from https://www.irs.gov/pub/irs-soi/tehistory.pdf

Ashworth, R., Boyne, G., \& Delbridge, R. (2007). Escape from the iron cage? Organizational change and isomorphic pressures in the public sector. Journal of public administration research and theory, 19(1), 165-187.

Berman, E. (2006). Performance and Productivity in Public and Nonprofit Organizations, Routledge.

BoardSource. (2017). Leading with Intent: 2017 National impact of nonprofit board practices survey. Washington, DC.

Boxenbaum, E. \& Jonsson, S. (2017). Isomorphism, diffusion and decoupling : Concept evolution and theoretical challenges. The Sage Handbook of Organizational Institutionalism. Edited by Royston Greenwood, Christine Oliver, Thomas B. Lawrence, and Renate E. Meyer. 2nd Edition. London : Sage Publications. pp. 77101.

Bradshaw, P. (2009). A contingency approach to nonprofit governance. Nonprofit Management and Leadership, 20(1), 60-81.

Bradshaw, P., Murray, V., \& Wolpin, J. (1992). Do nonprofit boards make a difference? An exploration of the relationships among board structure, process, and effectiveness. Nonprofit and Voluntary Sector Quarterly, 21(3), 227-249.

Brass, C. (February 29, 2012). Changes to the Government Performance and Results Act (GPRA): Overview of the New Framework of Products and Processes Government Organization and Management. Center for Homeland Security and Defence, Homeland Security Digital Library.

Bromley, P., \& Meyer, J. W. (2017). They are all organizations: The cultural roots of blurring between the nonprofit, business, and government sectors. Administration \& Society, 49(7), 939-966. 
Brown, W. A. (2005). Exploring the association between board and organizational performance in nonprofit organizations. Nonprofit Management and Leadership, 15(3), 317-339.

Brown, W. A. (2007). Board development practices and competent board members: Implications for performance. Nonprofit Management and Leadership, 17(3), 301-317.

Brudney, J. L. \& Murray, V. (1998). Do intentional efforts to improve boards really work? Nonprofit Management and Leadership, 8(4), 333-348.

Bullock, S. (2012). Montana attorney general's investigative report of Greg Mortenson and Central Asia Institute. State of Montana: Attorney General's Office.

Business Wire. (July 12, 2017). The Hartford introduces new management liability coverage for nonprofit organizations. Retrieved from https://www.businesswire.com/news/home/20170712005215/en/HartfordIntroduces-New-Management-Liability-Coverage-Nonprofit

California Attorney General, (2017). California Attorney General's guide to charities. Retrieved from https://oag.ca.gov/sites/all/files/agweb/pdfs/charities/publications/guide_for_chari ties.pdf

California Department of Justice. (2017). California Attorney General's guide for charities: Best practices for nonprofits that operate or fundraise in California. Charitable Trusts Section.

Carpenter, H. (2011). How we could measure community impact of nonprofit graduate students' service-learning projects: Lessons from the literature. Journal of Public Affairs Education, 17(1), 115-132.

Carver, J. (1997). Boards that make a difference: A new design for leadership in nonprofit and public organizations. Jossey-Bass Publishers, San Francisco, CA

Castor, T., \& Jiter, M. (2013). Learning by the 'seat of your pants': the socialization of nonprofit board members. Volunteering and communication: studies from multiple contexts. Edited by Peter Lang. New York, NY, pp. 85-104.

Chait, P., Ryan, P. \& Taylor, E. (2005). Governance as leadership; Reframing the work of nonprofit boards. Hoboken, NJ; BoardSource/Wiley.

Chan, C. (September 25, 2015). The Spirit of Giving and Charity in Ancient Times. Ancient Origins. Retrieved from https://www.ancient-origins.net/history/spiritgiving-and-charity-ancient-china-005033 Retrieved from

City of San Diego. (n.d.) Community Development Block Grant Program City of San Diego Nonprofit Academy. Retrieved March 15, 2019 from https://www.sandiego.gov/cdbg/nonprofit-academy 
Cornforth, C. (2012). Nonprofit governance research: Limitations of the focus on boards and suggestions for new directions. Nonprofit and Voluntary Sector Quarterly, 41(6), $1116-1135$.

Corporation for National and Community Service. (2017). Organizational capacity assessment tool. Washington, DC. Retrieved from https://www.nationalservice.gov/sites/default/files/resource/CNCS_Organization_ Assessment_Tool_Final_082517_508_0.pdf

Council of Nonprofits. (n.d.). IRS form 1023 EZ. Retrieved March 12, 2018 from: https://www.councilofnonprofits.org/trends-policy-issues/irs-form-1023-ez

Coule, T. M. (2015). Nonprofit governance and accountability broadening the theoretical perspective. Nonprofit and Voluntary Sector Quarterly, 44(1), 75-97.

Dietz, N., Lott, C., Barber, P., \& Shelly, M. (2017). Exploring the relationship between state charitable solicitation regulations and fundraising performance. Nonprofit Policy Forum. 8(2), pp. 183-204.

Dillman, D. (2000). Mail and internet surveys: The tailored design method. 2nd Edition. New York, NY: John Wiley \& Sons.

Dillman, D, Smyth, J., \& Christian, L. (2014). Internet, phone, mail, and mixed-mode survey: The tailored design approach. 4th edition. Wiley; Hoboken, NJ.

DiMaggio, P. \& Powell, W. (1983). The iron cage revisited: Institutional isomorphism and collective rationality in organizational fields. American Sociological Review, $48,47-60$.

Dobkin-Hall, P. (2003). A history of nonprofit boards in the United States. BoardSource, Washington, DC.

Dobkin-Hall, P. (2006). A historical overview of philanthropy, voluntary associations, and nonprofit organizations in the United States, 1600-2000. In W.W. Powell \& R. Steinberg (Eds), The nonprofit sector: A research handbook 2 nd Edition. New Haven, CT: Yale University Press, pp. 13-31.

Doherty, A., \& Hoye, R. (2011). Role ambiguity and volunteer board member performance in nonprofit sport organizations. Nonprofit Management and Leadership, 22(1), 107-128.

Ebrahim, A. (2010). The many faces of nonprofit accountability. In D. Renz \& R. Heman (Eds.) The Jossey-Bass handbook of nonprofit leadership and management, 4th Edition. (pp. 101-121). Hoboken, NJ: John Wiley \& Sons.

Fama, E., \& Jensen, M. (1983). Separation of Ownership and Control. The Journal of Law \& Economics, 26(2), 301-325.

FindLaw, (2016). California Corporate Code 309: Corporate Duties. Retrieved from http://codes.findlaw.com/ca/corporations-code/corp-sect-309.html 
Fishman, J., Schwarz, S., \& Mayer, L. (2015). Nonprofit organizations cases and materials, 5th Edition. St. Paul, MN: Thompson Reuters/Foundation Press

Forbes, D. P., \& Milliken, F. J. (1999). Cognition and corporate governance: Understanding boards of directors as strategic decision-making groups. Academy of Management Review, 24(3), 489-505.

Fremont-Smith, M. R. (2004). Governing nonprofit organizations: Federal and state law and regulation. Harvard University Press.

Frumkin, P., \& Galaskiewicz, J. (2004). Institutional isomorphism and public sector organizations. Journal of public administration research and theory, 14(3), 283307.

Gibelman, M., \& Gelman, S. R. (2001). Very public scandals: Nongovernmental organizations in trouble. Voluntas: International Journal of Voluntary and Nonprofit Organizations, 12(1), 49-66.

Gose, B. (2012). \$1million settlement in 'Three Cups' scandal offers warning to boards. Chronicle of Philanthropy. 24(11), 1.

Grassley, C. (May 24, 2017). Wounded Warrior Project Senate Report. United States Senate.

Greco, J. \& Sosa, E. (1999). The Blackwell guide to epistemology. Blackwell Publishers: New Jersey.

Hansmann, H., (1980), The role of non-profit enterprise. Yale Law Journal, 89(5), 835901.

Harris, M. (June 23, 2106) The Political Ban in 501 (c) (3): Its Odd History. Retrieved from https://www.forpurposelaw.com/501c3-political-ban-history/

Hegeseth, P. (2016). The VA scandal: Two years on. Retrieved from https://www.realclearpolitics.com/2016/04/07/the_va_scandal_two_years_on_379 910.html

Helge, T. L. (2009). Policing the good guys: Regulation of the charitable sector through a federal charity oversight board. Cornell Journal of Law and Public Policy, 19(1), $24-25$.

Helmig, B., Jegers, M., \& Lapsley, I. (2004). Challenges in managing nonprofit organizations: A research overview. Voluntas: International Journal of Voluntary and Nonprofit Organizations, 15(2), 101-116.

Herman, M. L. (2006). Pillars of accountability: A risk management guide for nonprofit boards. 2nd Edition. Washington, DC: Nonprofit Risk Management Center.

Herman, R.D. and Renz, D.O. (1999). Theses on nonprofit organizational effectiveness. Nonprofit and Voluntary Sector Quarterly. 28(2), 107-126. 
Herman, R. and Renz, D. (2000). Board practices of especially effective and less effective local nonprofit organizations. American Review of Public Administration, 30(2). 146-160.

Herman, R. and Renz, D. (2003). Advancing nonprofit organizational effectiveness research and theory. Nonprofit Management \& Leadership, 18(4). 399-415.

Herman, R. D., \& Renz, D. O. (2008). Doing things right: Effectiveness in local nonprofit organizations, a panel study. Public Administration Review, 64(6), 694-704.

Holland, T. (2002). Board accountability: Lessons from the field. Nonprofit Management \& Leadership, 12(4), 409-428.

Holland, T. P., \& Ritvo, R. A. (2008). Nonprofit organizations: principles and practices. Columbia University Press.

Holy Bible. (1986). The Holy Bible, New International Version. Holman Bible Publishers, Nashville: TN.

Hopkins, B. (2009). Legal responsibilities of Nonprofit Boards. BoardSource: Washington, DC.

Houle, C.O. (1997). Governing boards: Their nature and nurture. Jossey Bass: San Francisco

Hrywna, M. (2016). Layoffs Hit Wounded Warrior Project, 50\% of Executives. Retrieved from http://www.thenonprofittimes.com/news-articles/layoffs-hit-woundedwarrior-project-50-executives/

Independent Sector. (January 5, 2017). Standards for excellence: An ethics and accountability code for the nonprofit sector. Retrieved from https://standardsforexcellence.org/Home-2/code

Internal Revenue Service (2017a). Exemption requirements 501(c)3 organizations. https://www.irs.gov/charities-non-profits/charitable-organizations/exemptionrequirements-section-501c3-organizations

Internal Revenue Service (2017b). Governance and related topics - 501(c)3 organizations. Retrieved from https://www.irs.gov/pub/irstege/governance_practices.pdf

Internal Revenue Service. (2016a). The agency, its mission, and statutory authority. Retrieved from https://www.irs.gov/about-irs/the-agency-its-mission-andstatutory-authority

Internal Revenue Service. (2016b). Return of organization exempt from income tax form 990. Retrieved from https://www.irs.gov/pub/irs-pdf/f990.pdf 
Internal Revenue Service. (2016c). Tax Exemption. Retrieved from https://www.irs.gov/charities-non-profits/charitable-organizations/exemptpurposes-internal-revenue-code-section-501c3

Jackson D, and Holland, T. (1998). Measuring the effectiveness of nonprofit boards. Nonprofit and Voluntary Sector Quarterly. 27(2), 159-182.

Jepperson, R. L. (2002). The development and application of sociological neoinstitutionalism. New Directions in Contemporary Sociological Theory, Joseph Berger and Morris Zelditch, Jr. Eds., pp. 229-266.

Kearns, K. P. (1996). Managing for accountability: Preserving the public trust in public and nonprofit organizations. Jossey-Bass: San Francisco

Kelch, H. (January 10, 2014) What you need to know about the non-profit revitalization act of 2013. Retrieved from http://www.cullenanddykman.com/news-advisories68.html

Koppell, J. G. (2005). Pathologies of accountability: ICANN and the challenge of "multiple accountabilities disorder". Public administration review, 65(1), 94-108.

Lecy, J., Schmitz, H., Swedlund, H. (2012). Non-governmental and not-for-profit organizational effectiveness: A modern synthesis. Voluntas. 23, 434-457.

Legal Career Path (n.d.). What is Corporate Law? Retrieved March 5, 2018. https://legalcareerpath.com/what-is-corporate-law/

Legal Information Institute. (2017) U.S. Tax Law: Subchapter F. Exempt Organizations. Retrieved from https://www.law.cornell.edu/uscode/text/26/subtitle-A/chapter1/subchapter-F

Light, P. (2004). Sustaining nonprofit performance: the case for capacity building and the evidence to support it. Brookings Institution, Washington, DC.

Masaoka, J. (July 7, 2010). Nonprofit conflict of interest: A 3-dimensional view. Blue Avocado Retrieved from https://blueavocado.org/leadership-andmanagement/nonprofit-conflict-of-interest-a-3-dimensional-view/

McLean, C. (April 25, 2016).The Impact of Form 1023-EZ. GuideStar Blog. Retrieved from https://trust.guidestar.org/2015/06/24/the-impact-of-form-1023-ez-2/

Meyer, J. \& Rowan, B. (1977). Institutionalized organizations: Formal structures as myth and ceremony. American Journal of Sociology, 83, pp. 340-363.

Miller, G. E. (1990). The assessment of clinical skills/competence/performance. Academic medicine, 65(9), S63-67.

Miller, J. (2002). The board as a monitor of organizational activity. The applicability of agency theory to nonprofit boards. Nonprofit Management \& Leadership, 12(4), 429-450. 
Miller, V. \& Jablin, F. (1991). Information seeking during organizational entry: Influences, tactics, and a model of the process. Academy of Management. 15(1), 92-120.

Miller-Millesen, J. L. (2003). Understanding the behavior of nonprofit boards of directors: A theory-based approach. Nonprofit and Voluntary Sector Quarterly, 32(4), 521-547.

Mirabella, R. M. (2007). University-based educational programs in nonprofit management and philanthropic studies: A 10-year review and projections of future trends. Nonprofit and Voluntary Sector Quarterly, 36(4_suppl), 11S-27S.

National Center for Charitable Statistics. (2018). Nonprofit sector in brief. Retrieved from https://nccs.urban.org/project/nonprofit-sector-brief

National Council of Nonprofits. (n.d.). 1023 EZ Policy Topic. Retrieved March 2, 2019. https://www.councilofnonprofits.org/trends-policy-issues/irs-form-1023-ez

Nonprofit Association of Oregon. (2017). Assessment tool for nonprofit organizations. Retrieved from https://nonprofitoregon.org/sites/default/files/uploads/file/NP\%20Org\%20Self\%2 0Assessment_0.pdf

Nonprofit Institute. (2018). State of Nonprofits 2018. Retrieved from http://catcher.sandiego.edu/items/usd/2018_SONP_Report_Layout_online.pdf

O'dell, C., \& Grayson, C. J. (1998). If only we knew what we know: Identification and transfer of internal best practices. California management review, 40(3), 154-174.

Ostrower, F. \& Stone, M.M. (2006) Governance: Research trends, gaps, and future prospects. In W.W. Powell \& R. Steinberg (Eds), The nonprofit sector: A research handbook, 2nd Edition. New Haven, CT: Yale University Press, pp. 612628.

Overton G. and Frey, J. Editors (2002) Guidebook for Directors of Nonprofit Corporations 2nd Edition, Committee on Nonprofit Corporations. American Bar Association, Chicago: IL.

Palmiter, A. (2010). Duty of obedience: The forgotten duty. New York Law Review, $55(11)$.

Phillips, D. (2016). Wounded Warrior Project Spends Lavishly on Itself, Insiders Say. Retrieved from https://www.nytimes.com/2016/01/28/us/wounded-warriorproject-spends-lavishly-on-itself-ex-employees-say.html

Poister, T. H. (2008). Measuring performance in public and nonprofit organizations. John Wiley \& Sons.

Preston, J. B., \& Brown, W. A. (2004). Commitment and performance of nonprofit board members. Nonprofit Management and Leadership, 15(2), 221-238. 
Reid, C. \& Janisch, J. (January 26, 2016). "Wounded Warriors Project Accused of Wasting Donation Money". CBS News. Retrieved from https://www.cbsnews.com/news/wounded-warrior-project-accused-of-wastingdonation-money/

Renz, D. O. (2004). An overview of nonprofit governance. In Philanthropy in America. Santa Barbara, CA.

Renz, D. O. (2010). The Jossey-Bass handbook of nonprofit leadership and management. John Wiley \& Sons.

Renz, D. O., \& Andersson, F. O. (2013). Nonprofit governance: A review of the field. Nonprofit governance: Innovative perspectives and approaches. Edited by Chris Cornforth and William Brown. Routledge.

Riggio, R. E., \& Orr, S. S. (2004). Improving leadership in nonprofit organizations, Hoboken, NJ: John Wiley \& Sons.

Robbins, K. (2006) The Nonprofit Sector in Historical Perspective: Traditions of Philanthropy in the West. In W.W. Powell \& R. Steinberg (Eds), The nonprofit sector: A research handbook 2nd Edition. New Haven, CT: Yale University Press, pp. 13-31.

Russell Reynolds Associates. (2016). Who sits at the boardroom table? A look inside nonprofit boards. Retrieved from https://www.russellreynolds.com/en/Insights/thoughtleadership/Documents/Who\%20sits\%20at\%20the\%20boardroom\%20table\%20$\% 20 \mathrm{~A} \% 20$ look\%20inside\%20nonprofit\%20boards.pdf

Salamon, L. (2012). The state of nonprofit America. Washington, DC: Brookings Institution Press.

Schwab Foundation for Social Enterprise Governance of Social Enterprise World Economics Forum (N.D) Corporation for National and Community Service Organizational Capacity Assessment Tool. Retrieved from https://www.schwabfound.org/resources?page=1

Scott, C. (2000). Accountability in the regulatory state. Journal of law and society, 27(1), 38-60.

Scott, R. (2008) Institutions and organizations: Ideas and interests, $3^{\text {rd }}$ Edition. Los Angeles, CA: Sage Publications.

Shapiro, R. (November 12, 2001). United Way leader's fraud scandal marred charitable legacy. Washington Post.

Sieff, K. (October 12, 2014). Mortenson returns to Afghanistan, trying to move past his 'Three Cups of Tea' disgrace. Washington Post 
Slim, H. (2002) By what authority? The legitimacy and accountability of nongovernmental organizations. The Journal of Humanitarian Assistance. The International Council on Human Rights Policy International Meeting on Global Trends and Human Rights - Before and After September 11. Geneva, Switzerland, January 10-12, 2002.

Smith, S. (2014). Accountability in the nonprofit sector. In The Oxford Handbook of Public Accountability, Oxford Publishers, Oxford: London.

Stanford. (2017). Stanford survey on the leadership and management of the nonprofit sector.

Swords, P. (1997, October). Form 990 as a Tool for Nonprofit Accountability. In Governance of Nonprofit Organizations: Standards and Enforcement Conference, New York University School of Law, New York.

Tschirhart, M., Reed, K. K., Freeman, S. J., \& Anker, A. L. (2009). Who serves? Predicting placement of management graduates on nonprofit, government, and business boards. Nonprofit and Voluntary Sector Quarterly, 38(6), 1076-1085.

United States Department of Labor. (August 31, 2018) Nonprofits account for 12.3 million jobs, 10.2 percent of private sector employment, in 2016. Bureau of Labor Statistics. Retrieved from https://www.bls.gov/opub/ted/2018/nonprofits-accountfor-12-3-million-jobs-10-2-percent-of-private-sector-employment-in2016.htm?view_full

University of Pennsylvania. (April, 1904). The modern law of charities as derived from the statute of charitable uses. American Law Register, Department of Law.

Van Puyvelde, S. (2016). Nonprofit organization governance: A theoretical review. Voluntaristics Review, Advance online publication.

Verbruggen, S., Christiaens, J., \& Milis, K. (2011). Can resource dependence and coercive isomorphism explain nonprofit organizations' compliance with reporting standards?. Nonprofit and Voluntary Sector Quarterly, 40(1), 5-32.

Verschuere, B., Verhoest, K., Meyers, F., \& Peters, B. G. (2006). Accountability and accountability arrangements in public agencies. In Autonomy and Regulation: Coping with agencies in the modern state. Tom Christensen and Per Laegreid editors. Northampton, MA: Edgar Elgar, pp. 268-300.

Vogt, P. (2005). Dictionary of Statistics \& Methodology. A Nontechnical Guide for the Social Sciences, $3^{\text {rd }}$ Edition. Sage Publications: Thousand Oaks, CA.

Volz, M. (April 5, 2012). Charity must repay \$1M. Star Tribune, Associated Press.

Wexler, Robert. (September, 2010). What every nonprofit board member should know. Adler \& Colvin Law Corporation, San Francisco, CA. 
Worth, M. (2017). Nonprofit Management: Principles and Practice, $4^{\text {th }}$ Edition. Sage: Los Angeles.

Wright, B. E., \& Millesen, J. L. (2008). Nonprofit board role ambiguity: Investigating its prevalence, antecedents, and consequences. The American Review of Public Administration, 38(3), 322-338.

Wyland, M. (July 17, 2018). How many nonprofits are there?: What the IRS's nonprofit automatic revocation and 1023 EZ processes left behind. Nonprofit Quarterly. Retrieved from https://nonprofitquarterly.org/2018/07/17/how-many-nonprofits$1023 \mathrm{ez} /$

Young, D. (1999). Nonprofit Management Studies in the United States: Current Developments and Future Prospects. Journal of Public Affairs Education, 5(1), 13-23.

Zagzebski, L. (1996). Virtues of the Mind: An Inquiry into the Nature of Virtue and Ethical Foundations of Knowledge. Cambridge: Cambridge University Press.

Zeichner, O. Massachusetts Bay Company Retrieved March 4, 2019 from https://www.scholastic.com/teachers/articles/teaching-content/massachusetts-baycompany/ 


\section{Appendices}

\section{Appendix A Survey Instrument}

For information about the survey instrument, please contact the author at crystaltrull@sandiego.edu. 


\title{
Appendix B Email Invitation to Participate in Study
}

\author{
Dear Nonprofit Leader,
}

My name is Crystal Trull and I am a doctoral student at the University of San Diego as well as a long-time San Diego nonprofit practitioner and consultant. In my work in the nonprofit sector, I meet boards of all shapes and sizes that want to do their jobs well, but are often confronted with an uncertainty as to what their actual duties are. As I ventured into the world of academia, I found that that there is an amazing opportunity to strengthen nonprofit boards and executives using academic research that would be relevant and useful for nonprofit organizations. In response, I am embarking on an ambitious, groundbreaking study for my doctoral dissertation and I would be honored to have your participation.

The purpose of the study is to understand how much nonprofit board members and executives know about their fiduciary responsibilities and how they apply that knowledge to their governance activities. My hope is that this study will not only provide useful data that nonprofit leaders can use to strengthen their boards, but that also informs funders, academics, and governments to engage their support of board development and training.

This study is intended for two types of nonprofit leaders who govern nonprofit organizations that are located in San Diego County: 1) Individuals who serve as a voting member of a board of directors and 2) the most senior executive staff (e.g. Executive Director, Chief Operating Officers, Chief Development Officer, etc.). If none of this criteria fits you, please forward this request to someone in your organization, or others in your networks, who might meet the criteria. If you are one of the leaders that meet the criteria, then please let me know if you would be willing to participate in this study by emailing me at \#\#\# or by calling/texting me at \#\#\#.

The survey will take about 15 minutes and you can exit at any time. All of your answers are confidential and will only be reported in aggregate. At the end of this survey, you will be asked for your name and email just in case I need to follow up with you for clarification or if you would like to receive the results of this study.

Your participation is vital to better equip nonprofit leaders. Should you have any questions, I can be reached via email or cell/text as indicated above. I will follow up with you in week or so, if you haven't responded, to confirm that you received this request and if you are interested in participating.

Many thanks in advance for your participation.

Sincerely, Crystal Trull, M.A.

Institutional Review Board \#2018-181 


\section{Institutional Review Board Approval}

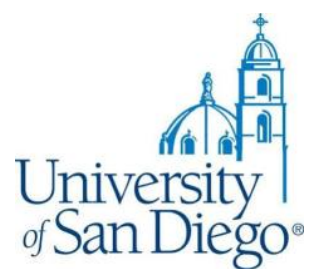

Jan 3, 2018 9:27 AM PST

Crystal Trull

School of Leadership \& Education Sciences

Re: Expedited - Initial - IRB-2018-181, Nonprofit Governance: Board and Executive Knowledge and Application of Fiduciary Duties

Dear Crystal Trull:

The Institutional Review Board has rendered the decision below for IRB-2018-181, Nonprofit Governance: Board and Executive Knowledge and Application of Fiduciary Duties.

Decision: Approved

Selected Category: 7. Research on individual or group characteristics or behavior (including, but not limited to, research on perception, cognition, motivation, identity, language, communication, cultural beliefs or practices, and social behavior) or research employing survey, interview, oral history, focus group, program evaluation, human factors evaluation, or quality assurance methodologies.

Findings: None

Research Notes:

Internal Notes:

Note: We send IRB correspondence regarding student research to the faculty advisor, who bears the ultimate responsibility for the conduct of the research. We request that the faculty advisor share this correspondence with the student researcher.

The next deadline for submitting project proposals to the Provost's Office for full review is N/A. You may submit a project proposal for expedited or exempt review at any time.

Sincerely,

Dr. Thomas R. Herrinton

Administrator, Institutional Review Board

Office of the Vice President and Provost

Hughes Administration Center, Room 2145998 Alcalá Park, San Diego, CA 92110-2492

Phone (619) 260-4553 • Fax (619) 260-2210 • www.sandiego.edu 